UNIVERSIDADE DE SÃO PAULO

FACULDADE DE ECONOMIA, ADMINISTRAÇÃO E CONTABILIDADE DEPARTAMENTO DE ADMINISTRAÇÃO PROGRAMA DE PÓS-GRADUAÇÃO EM ADMINISTRAÇÃO

A INFLUÊNCIA DOS TIPOS DE MARCA NA OPINIÃO DE VALOR E PREFERÊNCIA DE COMPRA DE UM PRODUTO

Luiz Alberto Marcondes Homen de Mello e Castro

Orientadora: Profa. Dra. Maria Aparecida Gouvêa

SÃO PAULO 
Prof. Dr. João Grandino Rodas

Reitor da Universidade de São Paulo

Prof. Dr. Reinaldo Guerreiro

Diretor da Faculdade de Economia, Administração e Contabilidade

Prof. Dr. Adalberto Américo Fischmann

Chefe do Departamento de Administração

Prof. Dr. Lindolfo Galvão de Albuquerque Coordenador do Programa de Pós-Graduação em Administração 


\title{
A INFLUÊNCIA DOS TIPOS DE MARCA NA OPINIÃO DE VALOR E
} PREFERÊNCIA DE COMPRA DE UM PRODUTO

Dissertação apresentada ao Departamento de Administração da Faculdade de Economia, Administração e Contabilidade da Univesridade de São Paulo como requisito para obtenção do título de Mestre em Administração.

Orientadora: Profa. Dra. Maria Aparecida Gouvêa

\author{
Versão Original
}

SÃO PAULO 


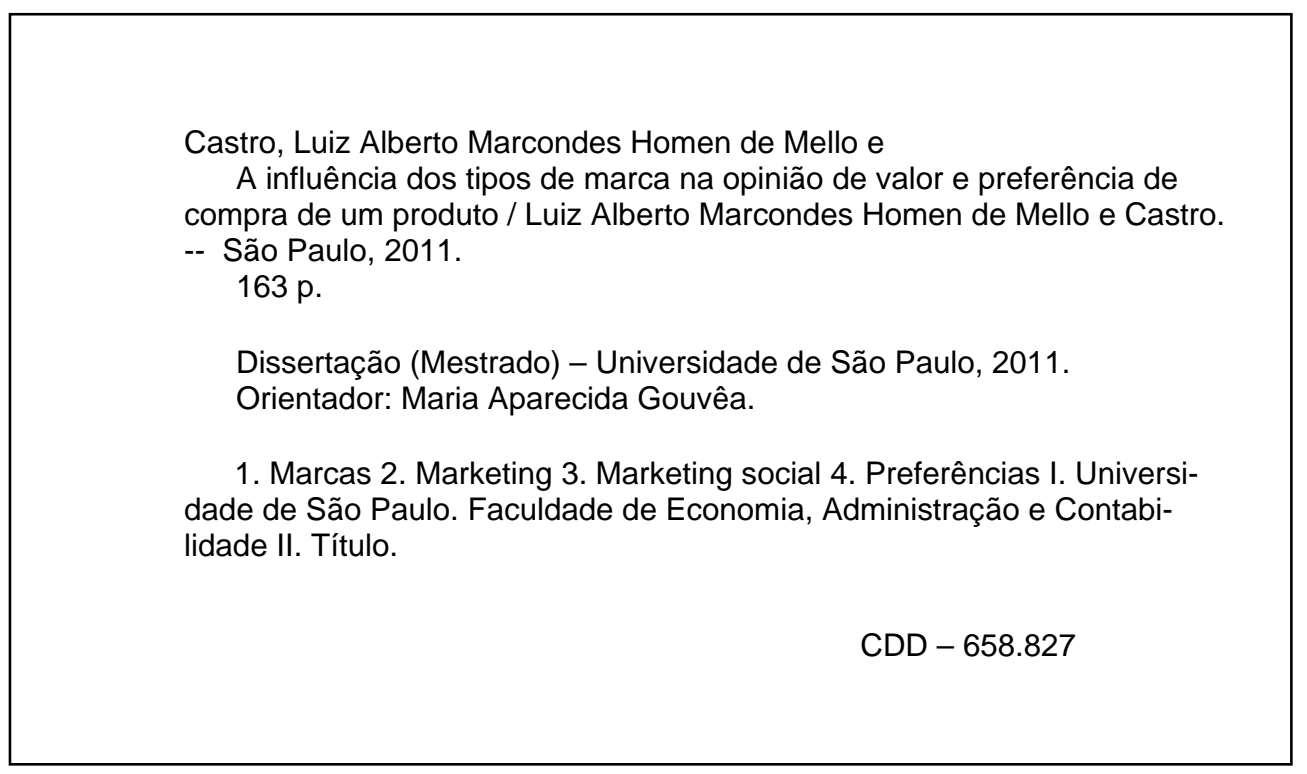


Aos meus pais, sempre presentes, amorosos e preocupados em não deixar faltar nada para os filhos. Aos meus irmãos, pelo companherismo, amizade e amor. 
Agradeço à minha família, sempre preocupada com a minha formação intelectual, por ter me amparado quando precisei e por ter garantido que eu tivesse a tranquilidade necessária para poder realizar os meus estudos.

Faço uma menção honrosa à professora Maria Aparecida Gouvêa, minha orientadora, por ter desde o segundo ano da graduação me acompanhado no meu desenvolvimento no campo da pesquisa acadêmica, sempre me incentivando a publicar e desenvolver novas idéias. Agradeço, também, ao professor Lindolfo Galvão de Albuquerque, por ter me aceito no Programa de Educação Tutorial (PET) da FEA/USP, do qual era tutor, o que me auxiliou a desenvolver ainda mais os meus conhecimentos em Administração e pesquisa.

Aos professores Geraldo Luciano Toledo e Antônio Francisco Serralvo, agradeço pelas valiosas contribuições dadas durante o meu exame de qualificação, sendo que, ao primeiro, faço uma especial menção pelas conversas de tardes e fins de aulas que muito adicionaram ao meu conhecimento.

Cabe aqui o reconhecimento ao auxílio que as Instituições de Ensino contatadas me deram na tarefa de divulgar a minha pesquisa a fim de obter participação das pessoas. E, a esses 260 respondentes que cederam algum tempo de sua vida para responder o meu questionário, deixo-lhes um sincero agradecimento.

Obrigado ao corpo docente da FEA/USP e aos amigos que dela ganhei pela convivência, ensinamentos, amizade e conhecimento que me possibilitaram chegar até aqui.

Por fim, agradeço a Deus, que me iluminou e protegeu nos momentos de dificuldades. 


\section{RESUMO}

Tida inicialmente como um artifício de identificação do produtor e, desse modo, garantia de qualidade, a marca, desde o século $\mathrm{XX}$, passou a ser considerada um poderoso signo que representa, implicitamente, experiências, valores, idéias e mesmo personalidade para o consumidor, adicionando às suas funções iniciais a capacidade de influenciar a percepção em relação a uma oferta e comunicar características de quem a consome. Com o acirramento da competição entre as empresas, houve uma proliferação de marcas a fim de se obter distinção em relação aos concorrentes. Esse movimento foi mais forte na categoria de bens de consumo, onde os compradores reduziram sensivelmente o tempo gasto nas compras; assim, a marca torna-se necessária para fazer o produto "saltar" aos olhos do consumidor no curto espaço de tempo em que ele está observando a gôndola. Assim, muitos tipos de marca foram criados, cada um com características distintas na sua identidade e posicionamento e diferentes efeitos sobre o consumidor. A fim de ampliar o conhecimento sobre essas diferenças e auxiliar na escolha do tipo de marca mais adequado para uma determinada oferta, este estudo exploratório se propôs a avaliar a influência das marcas genéricas, de fabricante e social sobre a opinião de valor e preferência de compra de um produto. Para isso, entre os meses de março e julho de 2011, coletaram-se, de 260 brasileiros maiores de 18 anos, opiniões e preferência em relação a tipos de camisetas e seus atributos. Na análise dos dados empregou-se a análise conjunta e de conglomerados, o teste t e a mensuração da elasticidade-preço da demanda. Entre os resultados, obteve-se o modelo de preferência por camisetas para 184 respondentes, observando-se que o tipo predileto é o de marca genérica, que não exibe nenhum signo aparente, com alta qualidade e baixo preço, sendo a qualidade, seguido pela marca e depois o preço, os atributos mais importantes para a preferência por ela. Também, foi possível observar que esses 184 respondentes podem ser reunidos em seis grupos diferentes segundo as suas preferências, sendo que a preferência pelas marcas e a sensibilidade ao preço e qualidade variaram entre eles. Sobre a capacidade da marca em cobrar preços diferenciados, na opinião de toda a amostra válida (248 pessoas), a de fabricante e a social podem aplicar, em média, preços $57 \%$ e $25 \%$ maiores, respectivamente, em relação à genérica. Já em relação à elasticidade, utilizada como aproximação da medida de fidelidade do consumidor à marca, observou-se que, no caso da necessidade de se comprarem duas camisetas que se diferenciam apenas na cor, os 248 entrevistados revelaram menor elasticidade à marca genérica, seguida pela social e a de fabricante. Todas essas análises foram produzidas, também, segundo o gênero sexual e a preferência declarada pelo tipo de marca de cada participante. Portanto, com os resultados apresentados neste estudo, acredita-se ter contribuído para a geração de um comparativo entre os três tipos de marca avaliados que poderá servir de subsídio na decisão de qual tipo de marca adotar para uma oferta e servir de insumo para futuras pesquisas sobre o tema.

Palavras-chave: Marcas; Marketing; Marketing Social; Marketing de Causa; Preferência. 


\begin{abstract}
Taken initially as a producer's identification device and, in this way, quality warranty, since twentieth century, the brand started to be thought as a powerful sign that represents, implicitly, experiences, values, ideas and even personality for the consumer, adding to its initial functions the ability to influence the perception about an offer and communicate characteristics of those who consume it. With the increasing competition among the companies, a proliferation of brands occurred in order to gain distinction against competitors. This trend was stronger in the consumer goods category, where the buyers reduced significantly the time spent on shopping; so the brand becomes necessary to make the product pop-up to consumers' eyes in the short time he is looking to the shelf. Thus, many kinds of brands were created, each one with distinct characteristics of its identity and positioning, and different effects on the consumer. In order to increase knowledge about these differences and assist the choosing of the most appropriate brand type for a particular offering, this exploratory study was elaborated to analyze the influence of generic, manufacturer and social brands on the opinion of value and purchasing preference of a product. To achieve this objective, between March and July 2011, were collected from 260 Brazilians over 18 years, opinions and preferences regarding types of shirts and their attributes. In the data analysis, it was used the conjoint and cluster analysis, the t-test and the measurement of price elasticity of demand. Among the results, it was obtained the T-shirts preference model for 184 respondents, observed that the preferred type is the one of generic brand, which shows no apparent sign, with high quality and low price, being quality, followed by brand and then price, the attributes most important to the preference for it. Also, it was possible to observe that these 184 respondents can be divided into six different groups according to their preferences, being that the preference for brand and the price and quality sensitivity varied among the clusters. About the brand's ability to charge different prices, in the opinion of all the valid sample (248 people), the manufacturer and social brands may apply, on average, prices 57\% and 25\% higher, respectively, compared to the generic version. As for elasticity, used as a proxy measure of consumer loyalty to the brand, it was observed that in the case of the need to buy two shirts that differ only in color, the 248 respondents showed lower elasticity to the generic brand, followed by the social and manufacturer types. All these analyses were produced, also, according to sexual gender and the brand type stated preference of each participant. Therefore, with the results presented in this study, it is believed to have contributed to the generation of a comparison among the three brand types assessed, which may help in the decision of which type of brand to choose for an offer and serve as input for future research on the subject.
\end{abstract}

Keywords: Brand; Marketing; Social Marketing; Cause Marketing; Preference. 


\section{SUMÁRIO}

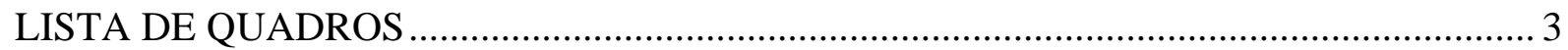

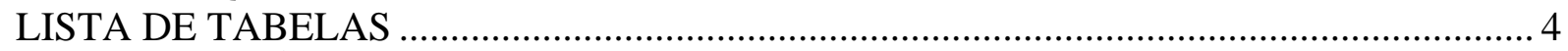

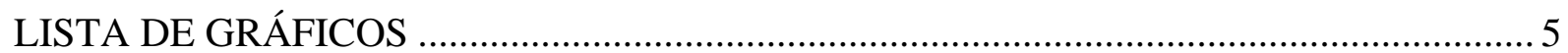

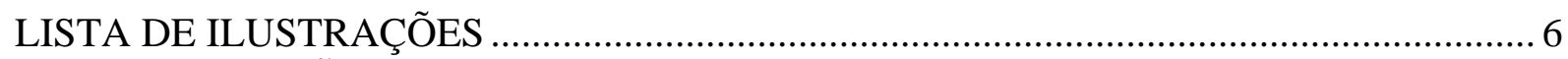

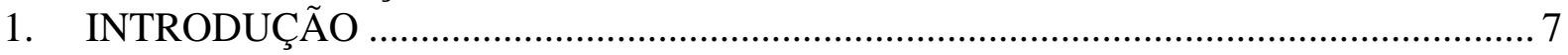

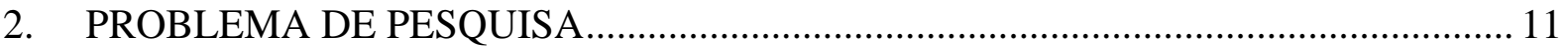

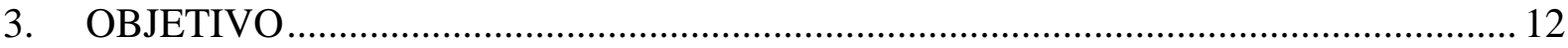

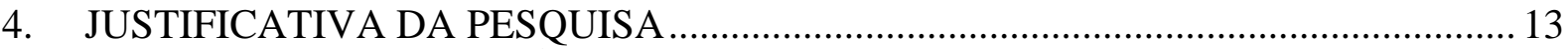

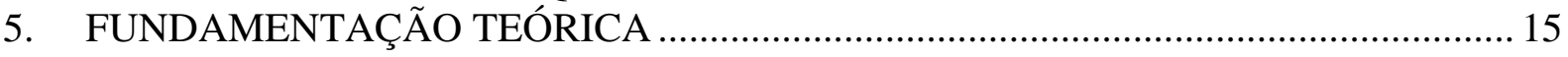

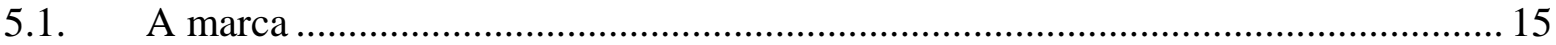

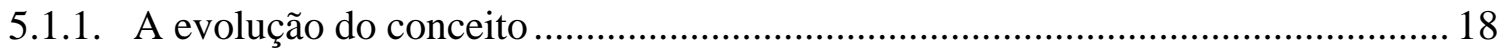

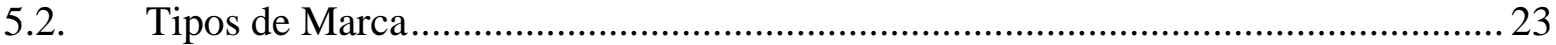

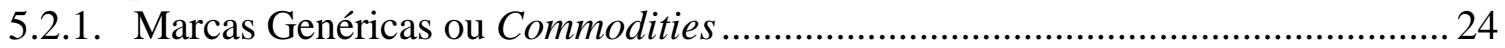

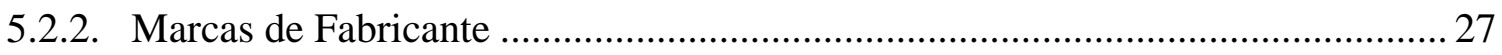

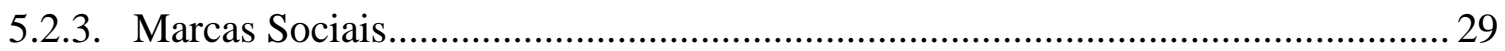

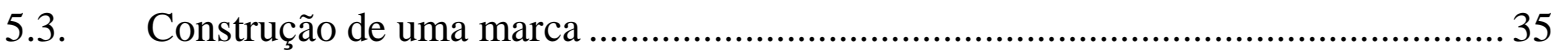

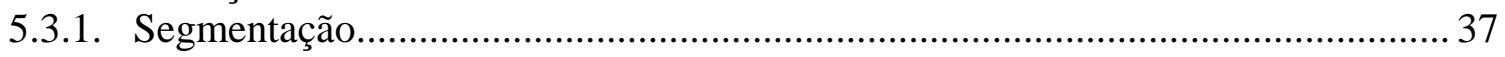

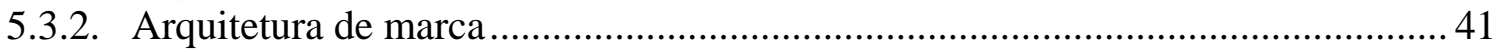

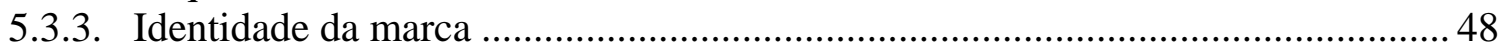

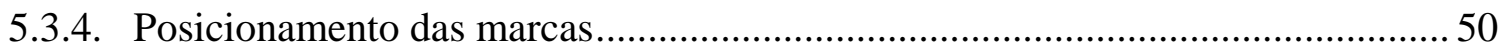

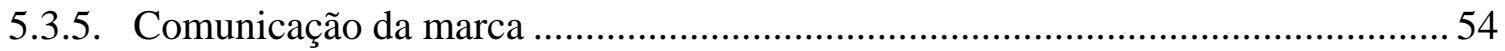

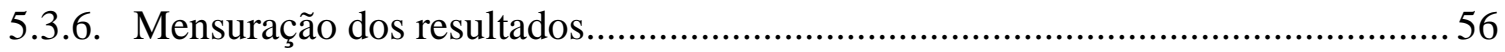

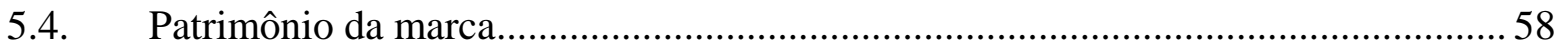

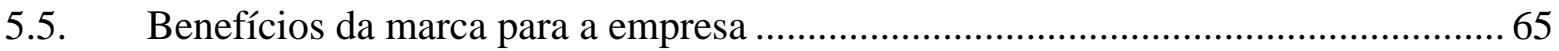

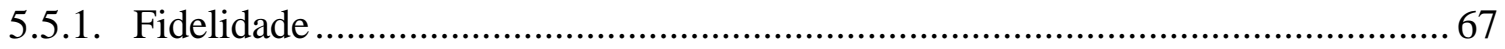

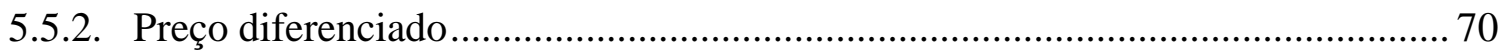

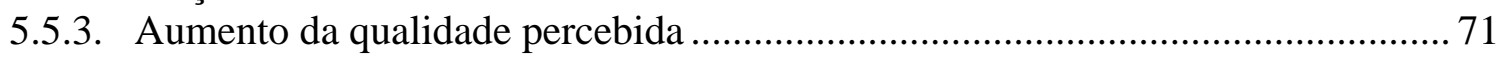

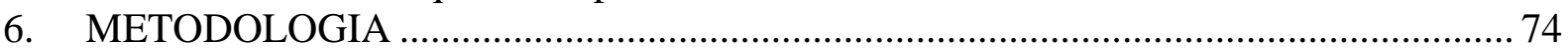

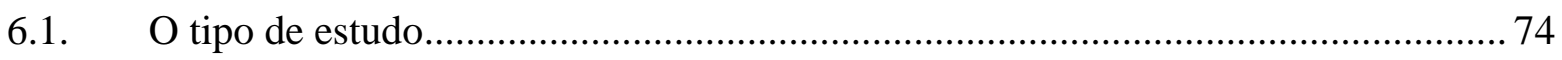

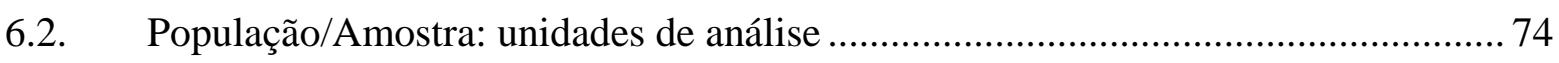

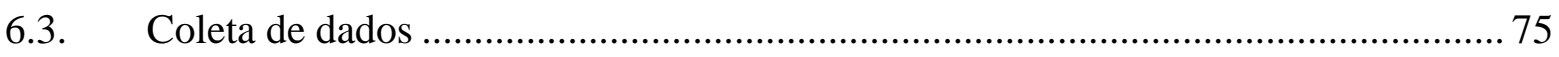

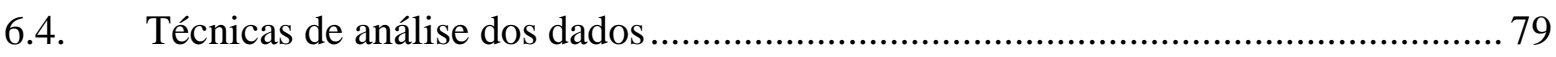

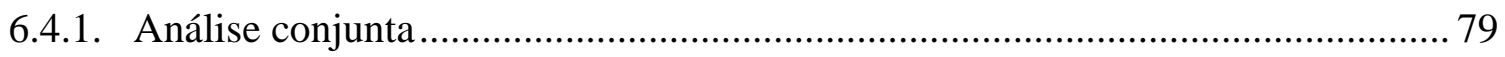

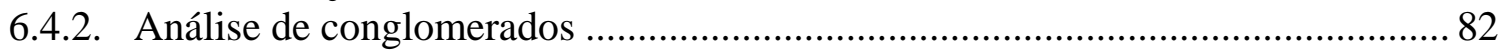

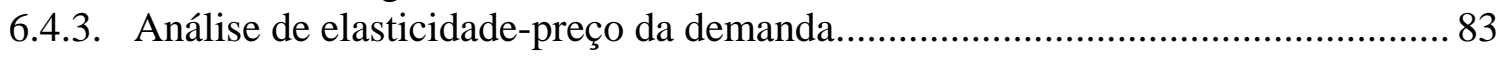

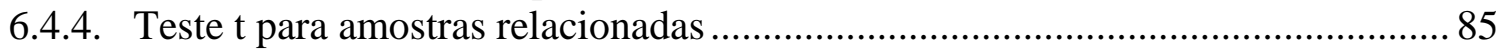

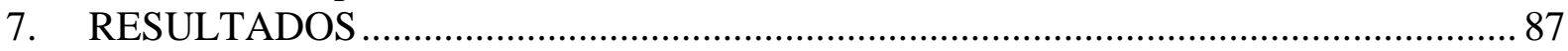

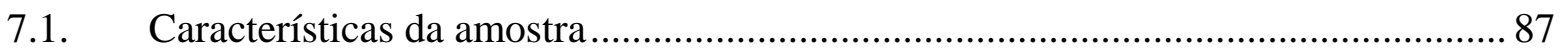

7.2. Análise da importância dos atributos na preferência de compra............................. 91 7.2.1. Análise da importância dos atributos na preferência de compra dos optantes pela

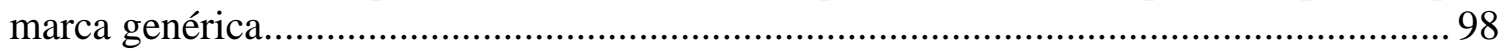
7.2.2. Análise da importância dos fatores na preferência dos optantes pela marca de fabricante 
7.2.3. Análise da importância dos fatores na preferência de compra dos optantes pela

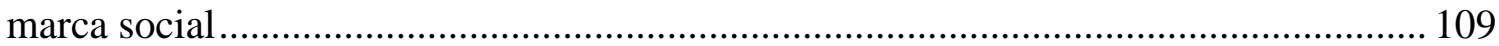
7.2.4. Análise da importância dos fatores na preferência de compra das pessoas segundo

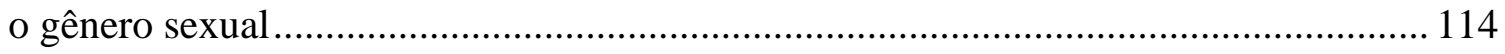

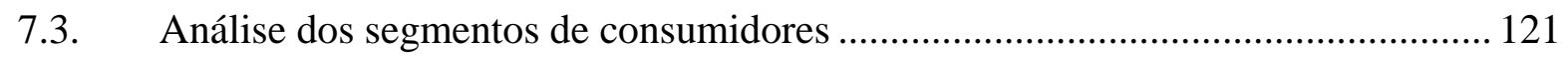

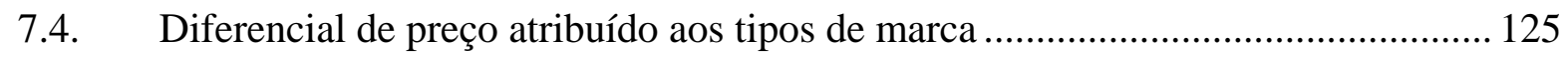

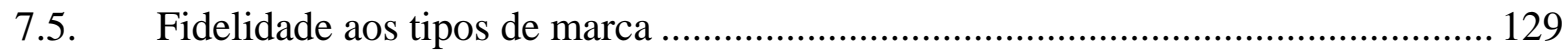

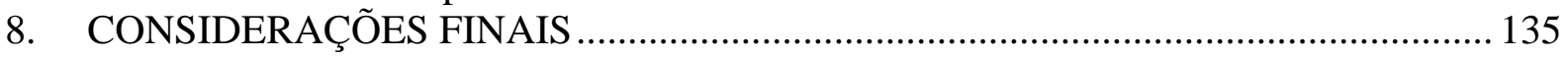

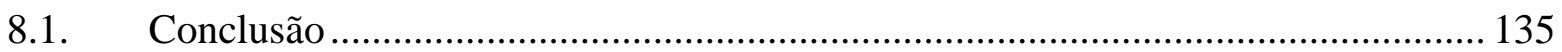

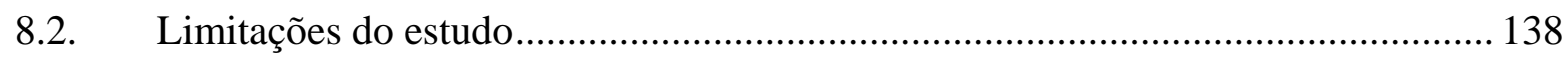

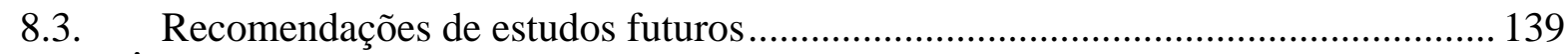

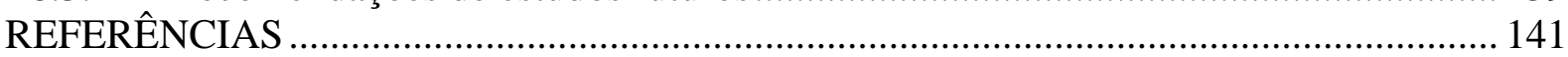

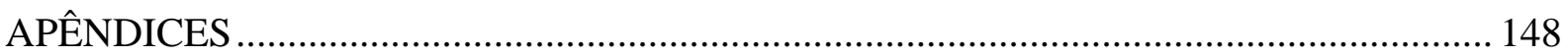




\section{LISTA DE QUADROS}

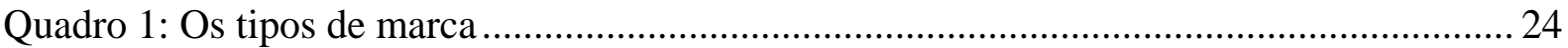

Quadro 2: As abordagens de desenvolvimento de marcas sociais.......................................... 34

Quadro 3: Relação das técnicas estatísticas com as análises realizadas ................................. 79

Quadro 4: Estímulos utilizados na análise conjunta......................................................... 81 


\section{LISTA DE TABELAS}

Tabela 1: Distribuição da opinião de importância dos atributos de uma camiseta .................. 91

Tabela 2: Medidas de qualidade do modelo de preferência da amostra.................................. 92

Tabela 3: Casos excluídos para melhoria do modelo de preferência da amostra......................93

Tabela 4: Preferência da amostra pelos dois estímulos de simulação..................................... 98

Tabela 5: Medidas de qualidade do modelo de preferência dos optantes pela marca genérica 99

Tabela 6: Casos excluídos para melhoria do modelo dos optantes pela marca genérica ......... 99

Tabela 7: Preferência dos optantes pela marca genérica pelos dois estímulos de simulação 104

Tabela 8: Medidas de qualidade do modelo de preferência dos optantes pela marca de

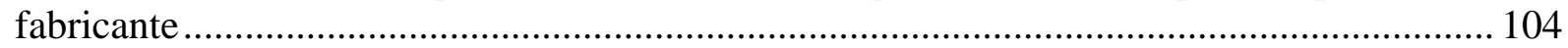

Tabela 9: Preferência dos optantes pela marca de fabricante pelos dois estímulos de simulação

109

Tabela 10: Medidas de qualidade do modelo de preferência dos optantes pela marca social 109

Tabela 11: Preferência dos optantes pela marca social pelos dois estímulos de simulação... 113

Tabela 12: Medidas de qualidade do modelo de preferência dos homens da amostra............ 114

Tabela 13: Casos excluídos para melhoria do modelo dos homens da amostra ..................... 115

Tabela 14: Medidas de qualidade do modelo de preferência das mulheres da amostra.......... 116

Tabela 15: Casos excluídos para melhoria do modelo das mulheres da amostra ................... 117

Tabela 16: Preferência dos homens e mulheres da amostra pelos dois estímulos de simulação

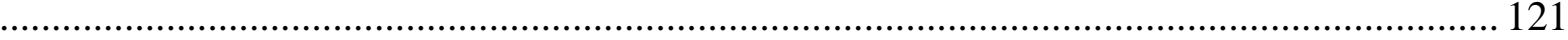

Tabela 17: Centróides iniciais utilizados no agrupamento não-hierárquico ........................... 122

Tabela 18: Resultado do teste F para as variáveis de aglomeração ..................................... 122

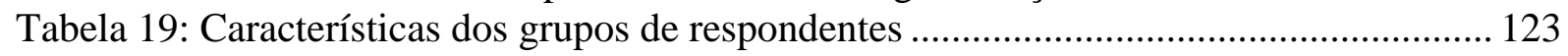

Tabela 20: Medidas de dispersão e posição dos preços das camisetas atribuídos pela amostra

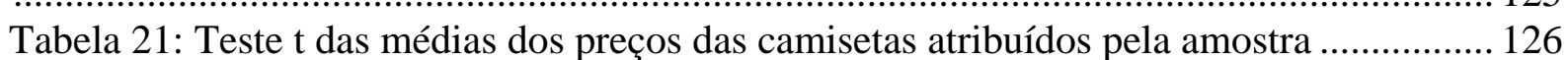

Tabela 22: Medidas de dispersão e posição dos preços das camisetas atribuídos pela amostra

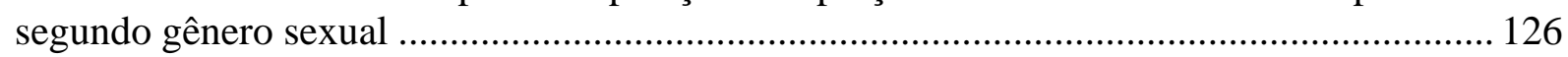

Tabela 23: Teste t das médias dos preços das camisetas atribuídos pela amostra segundo

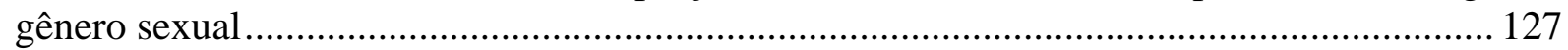

Tabela 24: Medidas de dispersão e posição dos preços das camisetas atribuídos pela amostra segundo preferência declarada de tipo de marca................................................................ 128

Tabela 25: Teste $\mathrm{t}$ das médias dos preços das camisetas atribuídos pela amostra segundo preferência declarada de tipo de marca ................................................................................ 128

Tabela 26: Medidas de dispersão e posição das elasticidades-preço da demanda segundo a

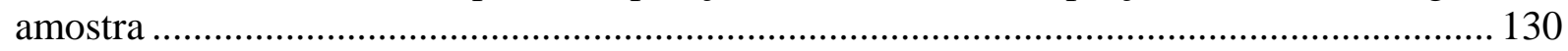

Tabela 27: Teste t das médias das elasticidades-preço da demanda segundo a amostra ....... 131

Tabela 28: Medidas de dispersão e posição das elasticidades-preço da demanda segundo

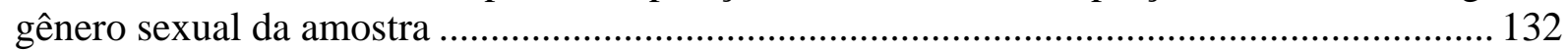

Tabela 29: Teste t das médias das elasticidades-preço da demanda segundo gênero sexual da

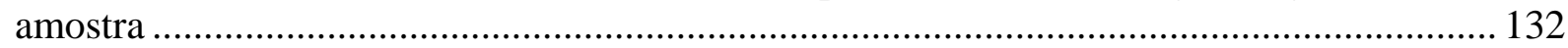

Tabela 30: Medidas de dispersão e posição das elasticidades-preço da demanda segundo preferência declarada de tipo de marca da amostra............................................................. 133

Tabela 31: Teste $\mathrm{t}$ das médias das elasticidades-preço da demanda segundo preferência

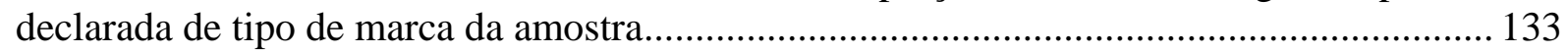




\section{LISTA DE GRÁFICOS}

Gráfico 1: Distribuição da amostra por gênero sexual ........................................................ 87

Gráfico 2: Distribuição da amostra por idade ................................................................... 88

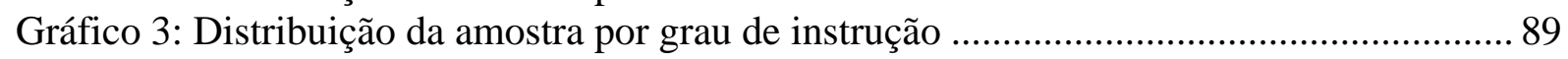

Gráfico 4: Distribuição da amostra por renda familiar mensal ............................................. 89

Gráfico 5: Distribuição da amostra por tipo de camiseta preferido ......................................... 90

Gráfico 6: Importância dos atributos da camiseta na preferência de compra da amostra ........ 94

Gráfico 7: Preferência da amostra pelos tipos de marca ........................................................ 95

Gráfico 8: Preferência da amostra pelos níveis de qualidade............................................... 96

Gráfico 9: Preferência da amostra pelos níveis de preço ..................................................... 97

Gráfico 10: Importância dos atributos da camiseta na preferência de compra dos optantes pela

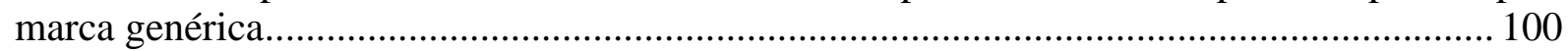

Gráfico 11: Preferência dos optantes pela marca genérica pelos tipos de marca..................... 101

Gráfico 12: Preferência dos optantes pela marca genérica pelos níveis de qualidade ............ 102

Gráfico 13: Preferência dos optantes pela marca genérica pelos níveis de preço................... 103

Gráfico 14: Importância dos atributos da camiseta na preferência de compra dos optantes pela

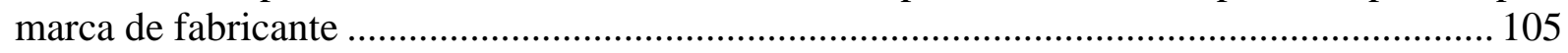

Gráfico 15: Preferência dos optantes pela marca de fabricante pelos tipos de marca................ 106

Gráfico 16: Preferência dos optantes pela marca de fabricante pelos níveis de qualidade .... 107

Gráfico 17: Preferência dos optantes pela marca de fabricante pelos níveis de preço............ 108

Gráfico 18: Importância dos atributos da camiseta na preferência de compra dos optantes pela

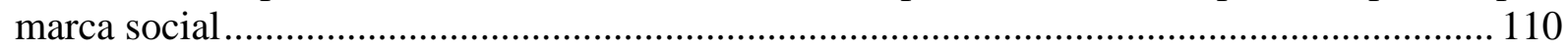

Gráfico 19: Preferência dos optantes pela marca social pelos tipos de marca ........................ 111

Gráfico 20: Preferência dos optantes pela marca social pelos níveis de qualidade ................ 112

Gráfico 21: Preferência dos optantes pela marca social pelos níveis de preço ....................... 113

Gráfico 22: Importância dos atributos da camiseta na preferência de compra dos homens e

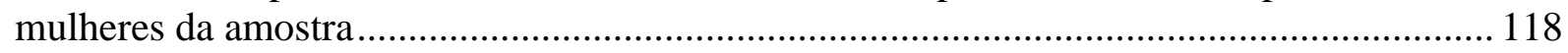

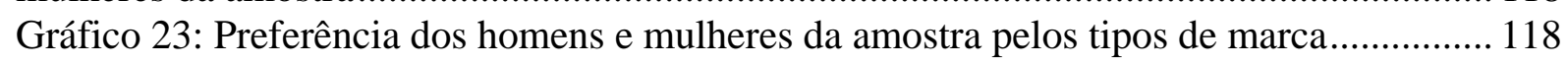

Gráfico 24: Preferência dos homens e mulheres da amostra pelos níveis de qualidade ........ 119

Gráfico 25: Preferência dos homens e mulheres da amostra pelos níveis de preço................ 120 


\section{LISTA DE ILUSTRAÇÕES}

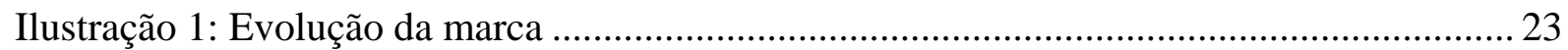

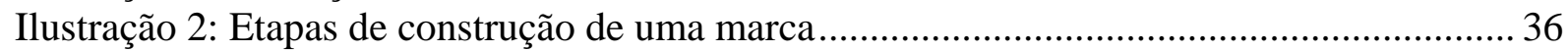

Ilustração 3: Pirâmide do patrimônio da marca baseado no consumidor.................................. 63

Ilustração 4: Ciclo de relacionamento dos benefícios da marca para a empresa ...................... 72

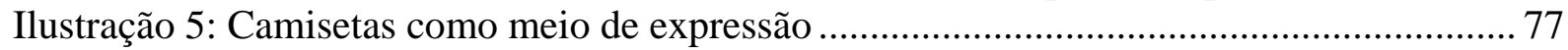

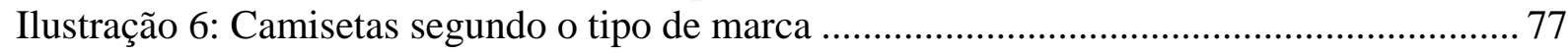




\section{INTRODUÇÃO}

A gestão das marcas foi desenvolvida por volta de 1930, mas muitas empresas costumavam usar o chamado "marketing intuitivo". Esse nome decorre do fato de que as decisões de marketing não eram baseadas no conhecimento do consumidor e na sua motivação de compra, nem mesmo eram usadas estratégias de marketing estruturadas e consistentes (KHAUAJA, 2005).

Até os anos 1990, essa forma “intuitiva” de gestão de marca funcionou porque muitos mercados eram protegidos e a competitividade não era tão alta. Porém, a partir dos anos 90, a sociedade começou a desenvolver um boom de demanda por produtos, movimento que foi denominado por consumismo. Este crescimento ocorreu devido ao desenvolvimento de alguns países e, desta forma, a ascensão social e econômica de milhões de novos consumidores. Este movimento, aliado ao desenvolvimento tecnológico e à redução dos custos de produção, promoveu um barateamento dos produtos, o que permitiu o acesso de pessoas a produtos que antes não poderiam adquirir.

Compensando o movimento da demanda, a oferta teve de ampliar-se para atendê-la. Os desenvolvimentos tecnológico, econômico e político de muitos países possibilitaram a redução dos custos de se abrir uma nova empresa e de se instalarem linhas de produção em massa; assim, houve uma explosão de novos empreendimentos. E, com o advento da globalização, houve uma queda das barreiras comerciais e os produtos deixaram de limitar-se ao seu entorno geográfico, começando agora a ocupar mercados internacionais.

Assim, produtos de diversas procedências invadiram os mercados, aumentando a oferta e, também, a diversidade de produtos e marcas disponíveis aos consumidores. Categorias que não existiam foram criadas e as que já existiam foram ampliadas.

Entre as razões para esse aumento da variedade de produtos e de marcas, Perez (2004) destaca algumas como:

- Necessidade de segmentação de mercados e de preenchimento de espaços decorrente do acirramento da concorrência;

- Objetivos competitivos tradicionais, tais como: ser o primeiro, superar a concorrência, ampliar o market share, obter mais lucro etc.;

- Necessidade de inovações constantes: novas tecnologias, novos ingredientes, mudanças de formato, tamanho, cor, apresentação, sabores etc.; 
- Expansão para novos mercados e a consequente necessidade de novos posicionamentos;

- Consumidores com amplo poder de escolha e, portanto, mais exigentes;

- Alterações no ambiente competitivo (oportunidades e ameaças);

- Exigências legais ou governamentais;

- Concorrência interna e/ou canibalização, especialmente em empresas adeptas do uso de marcas individuais;

- Aproveitamento de oportunidades;

- Complexidade das relações com os atores comerciais; e

- Novas alternativas de comercialização e distribuição, tendo o comércio eletrônico via Internet se constituído em um grande impulsionador.

Com a proliferação dos produtos presentes nos mercados e com a base econômica dos países deslocando-se do sistema produtivo para o consumo, houve um movimento da racionalidade material para o plano do desejo e, portanto, para o campo da subjetividade (ELLWOOD, 2004). Agora, é o imaterial que move o consumo; assim, o conceito e a marca que anima o produto são mais responsáveis pela sua escolha do que a sua qualidade (KAPFERER, 2004b).

Dois fatores que contribuíram para esse movimento são citados por Ellwood (2004), sendo um a fragmentação das identidades pessoal e social do ser humano, o que encoraja a criação de uma identidade pessoal pelo consumo das marcas, ou seja, o homem é o que compra; assim, os consumidores passam a buscar em grande parte um conteúdo imaginário, intangível e simbólico nos produtos que consomem.

O outro fator é a globalização, que, conforme Kapferer (2004b, p. 69), “leva à difusão dos modelos e símbolos (portanto, marcas) através das fronteiras e das culturas por meio da livre circulação de imagens” e, desse modo, complementa Ellwood (2004), faz o consumidor se perceber apenas como uma pequena parte de um todo e a necessitar dos valores expressos pelas marcas consumidas para se orientar nesse mundo conectado.

Neste contexto, as marcas foram primeiramente aplicadas em bens físicos, depois em serviços e, ultimamente, no terceiro setor, após as organizações sem fins lucrativos reconhecerem o valor do marketing para atingirem a vantagem competitiva (EWING; NAPOLI, 2005). Assim, as marcas assumiram um papel de destaque nas relações de compra e venda, deixando a simples função de facilitadora das transações comerciais para tornarem-se poderosos 
signos de representação do ser, do comportamento, do posicionamento social e econômico (PEREZ, 2004; MORT et al., 2007; CALDWELL; COSHALL, 2002).

Com um papel ampliado, as marcas, de acordo com Mowen e Minor (2003), passaram a funcionar como um facilitador na tomada de decisão de compra de produtos complexos (ou seja, com características de difícil avaliação), e, também, tornaram-se, segundo Keller (2002), influenciadoras da qualidade percebida, preço justo e fidelidade; em outras palavras, transformaram-se em um item com muita força para alterar o valor percebido de um produto.

Assim, as marcas passaram a representar uma propriedade legal valiosa que pode influenciar o comportamento do consumidor e ainda oferecer segurança de receitas futuras e estáveis para seu proprietário (KOTLER; KELLER, 2006), substituindo, desse modo, a capacidade de produção como item principal para avaliar empresas para aquisição ou fusão e justificando o fato de o valor final pago em algumas operações de compra de empresas ser maior que o valor patrimonial delas.

Sabendo destes benefícios, muitos gestores passaram a criar diferentes tipos de marcas para seus produtos, sendo algumas socialmente responsáveis e outras baseadas na tradição e no reconhecimento da sociedade. Todos querem ter sua marca. Os revendedores desejam diminuir o poder de barganha dos fabricantes, e vice-versa, os fornecedores querem ter direito à visibilidade da sua marca nos produtos acabados, os órgãos certificadores querem estampar o seu selo de qualidade, ou seja, nunca tantas marcas quiseram participar da criação do valor percebido e apropriar-se da maior parte possível dele (KAPFERER, 2004a).

Essa proliferação de marcas é demonstrada pelo comentário de Perez (2004, p. 10) de que "em todo o mundo, hoje, quase tudo é vendido com marca. Até frutas, como laranjas, maçãs e bananas, são carimbadas com a marca do produtor ou do distribuidor com o objetivo de distingui-las, principalmente por meio do reconhecimento da qualidade”.

Porém, o trabalho de gestão de marcas está ficando cada vez mais difícil, pois os consumidores estão mais informados e céticos quanto aos apelos promocionais falsos, o que é explicitado pelo consumerismo, que é um movimento por parte dos consumidores a fim de se protegerem e informarem por intermédio de práticas como a exigência de banimento de falsos apelos nas suas comunicações e de melhoria dos padrões de segurança dos produtos e serviços, além da vigilância e questionamento das práticas mercadológicas das empresas; eles também estão mais ecléticos, o que dificulta o atendimento de todo mercado com uma única marca; a concorrência está acirrada, o que tem tornado os produtos quase commodities; e o movimento de sustentabilidade corporativa tem criado considerável pressão na gestão de 
marca, obrigando-a a se ajustar à exigência de uma postura que considere os seus impactos sócio-ambientais (KHAUAJA, 2008; MAIO, 2003).

Ademais, os varejistas têm utilizado o seu poder de barganha e a proximidade com o cliente para comprimir as margens dos fabricantes por meio de negociações de preços mais agressivas e uso de marcas da sua rede. Ademais, a prioridade do gerenciamento de marcas não é mais o cliente, mas o acionista e, desse modo, não basta produzir resultado, ser eficaz, deve-se agora ser eficiente, gerar mais valor aplicando-se menos recursos (KAPFERER, 2004a).

O gerenciamento de marcas nesse ambiente de negócios mais exigente, dinâmico e competitivo, requer a diferenciação das mesmas de modo a possibilitar o adequado processo de segmentação e posicionamento de mercado da marca a fim de se lidar com a maneira como as diversas marcas são percebidas e agrupadas na mente do consumidor e atingir-se uma posição de destaque e sustentável nela. Porém, muitas empresas acabaram construindo equivocadamente as marcas de seus produtos, reduzindo o seu valor, ao invés de aumentá-lo. Neste cenário, faz-se necessário entender o efeito de diferentes tipos de marcas sobre a opinião e preferência de compra dos consumidores em relação a um produto. 


\section{PROBLEMA DE PESQUISA}

Tendo em vista a combinação das transformações observadas tanto no âmbito da economia como no ambiente tecnológico e a profusão de diferentes tipos de marcas, surgem as seguintes questões: (1) qual a opinião de valor do consumidor face às diferentes naturezas de marcas? (2) qual a influência da marca na preferência de compra de um produto? (3) qual a influência de diferentes marcas na preferência de um produto?

A partir destas questões, formula-se, então, a seguinte situação-problema: em um mercado específico, qual a influência da marca social, marca genérica e marca de fabricante sobre a opinião de valor e preferência de compra de um produto? 


\section{OBJETIVO}

O objetivo deste trabalho é estudar qual a influência de marcas sociais, marcas genéricas e marcas de fabricante, sobre a opinião de valor e preferência de compra de um produto.

Para alcançar esse objetivo, procede-se com o estudo da:

1. Importância da marca na preferência de compra de um produto;

2. Predileção das pessoas diante de produtos de marca social, marca genérica e marca de fabricantes;

3. Relação dos três tipos de marca com o preço justo e a qualidade percebida do produto;

4. Fidelidade/inelasticidade criada pela marca social, genérica e de fabricante; e

5. Existência de grupos de consumidores segundo a preferência pelos tipos de marca e sensibilidade à qualidade e ao preço do produto. 


\section{JUSTIFICATIVA DA PESQUISA}

Justifica-se este trabalho, em primeiro lugar, pela sua relevância. Segundo Miranda (2006, p. 35)

o comportamento de consumo simbólico é uma área de importância para [...] o marketing do século XXI, onde eventos como a globalização tendem a diminuir as fronteiras entre povos, culturas, países, o que por outro lado provoca no ser humano uma necessidade de ter uma identidade com um determinado grupo capaz de distinguilo das multidões.

Além disso, considerando-se a abrangência da difusão das marcas, a correta gestão das mesmas torna-se importante para as empresas conseguirem sobreviver em um ambiente em que cada dia novas marcas aparecem e produtos de marcas genéricas vêm para lutar por meio de preços baixos, tornando-se fundamental a investigação dos resultados dos diversos tipos de marca.

Reforçando esse ponto, Aaker (1996, p. 8) afirma que "cada patrimônio de marca cria valor em uma variedade de formas. A fim de administrar uma marca efetivamente e de tomar decisões informadas sobre atividades de construção de marcas, é importante ser sensível aos meios pelos quais marcas fortes criam valor”.

Outro ponto que realça a importância deste estudo é a sua originalidade, pois não se encontrou, na literatura pesquisada, trabalho acadêmico conhecido no Brasil com o escopo e com os objetivos ligados à avaliação da influência das marcas sociais, genéricas e de fabricante sobre a opinião de valor e preferência de compra.

Pesquisou-se, na biblioteca virtual PROQUEST, por publicações acadêmicas (e, desse modo, removeram-se da busca as críticas literárias e matérias em jornais) que abordassem o estudo de marcas e do branding, devendo ambos estarem relacionados, necessariamente, às marcas sociais, que são objeto de estudo desse trabalho e representam um diferencial entre os trabalhos já publicados.

A procura pelo termo "marca social” não encontrou resultado, mas, quando o termo foi "social brand", obtiveram-se 16 documentos, sendo que somente dois deles realmente abordavam o tema marcas sociais; o restante tratava de temas diversos, como os benefícios sociais de uma marca para o consumidor. Já o termo "social branding” gerou apenas um resultado, o qual não era um estudo sobre marcas sociais, mas fazia apenas uma menção a elas. 
Quando realizada a busca, simultânea, pelas palavras “branding” e “nonprofit” foram encontrados 81 resultados, mas apenas 20 relacionavam-se realmente a marcas sociais, embora nenhum deles abordasse exatamente o mesmo objetivo do estudo ora proposto.

A pesquisa pelo termo “cause-related brand” gerou quatro saídas, sendo que somente uma delas estudava marca social. E a busca por “cause-related branding” gerou duas saídas, mas só uma delas tratava de marcas sociais, a qual era um estudo que já havia aparecido na pesquisa simultânea pelas palavras "branding” e "nonprofit”.

Portanto, em nenhuma busca encontrou-se um estudo que fizesse uma análise comparativa da influência da marca social, genérica e de fabricante na decisão de compra do consumidor. Essas constatações convergem com o relato de Lafferty et al (2004), Faircloth (2005), Venable et al (2005), Ewing e Napoli (2005), Polonsky e Jevons (2006), Khan e Ede (2009), Wymer e Samu (2009) de que existem poucos estudos que exploram o tema das marcas sociais e o branding em setores não-lucrativos.

Conforme Lafferty e Goldsmith (2005, p. 424), “poucos estudos empíricos abordaram marketing de causas ou a aliança entre marca e causa”. Já Ewing e Napoli (2005) relatam que embora a gestão de marcas tenha ganhado relevância e aceitação no âmbito das empresas sem fins lucrativos, há poucos estudos sobre o tema e os que existem foram realizados nos últimos anos e são exploratórios ou conceituais.

Porém, a importância de se conhecer a influência de diferentes tipos de marca na preferência de compra já vem sendo destacada desde que os produtos assumiram características simbólicas e o consumo deles passou a depender mais do seu significado social do que da sua utilidade funcional (MIRANDA, 2006). Consequentemente é preciso conhecer a marca para fazê-la crescer na direção correta e, para realizar tal tarefa, os gestores de marca devem ter profundo entendimento das novas e persuasivas formas de posicioná-la (KOTLER; KELLER, 2006).

Conforme a constatação de Furrier (2008, p. 155), “em algumas categorias de produto, como cigarro e bebidas, marcas são critérios de escolha privilegiados”. Portanto, o estudo da influência dos tipos de marca é importante, pois, como afirma Kotler (2000, p. 426), “o estabelecimento de uma marca é a arte e a essência do marketing”, sendo a capacidade de gerir uma marca a habilidade mais característica dos profissionais de marketing. Assim, o correto e profundo conhecimento das marcas é um ponto essencial para se entender e aplicar corretamente os conceitos e aprendizados de marketing. 


\section{FUNDAMENTAÇÃO TEÓRICA}

Este capítulo é estruturado em cinco partes. A primeira foca no conceito de marca e a sua evolução no tempo. Na sequência, são apresentados os tipos de marca estudados. Na terceira parte, é feita uma estruturação dos passos necessários para se construir uma marca, apresentando-se uma revisão teórica sobre segmentação, arquitetura, identidade, posicionamento, comunicação e avaliação da marca. A seção 5.4 apresenta uma revisão sobre o patrimônio da marca e alguns modelos desenvolvidos para calculá-lo. Por fim, a última parte trata dos benefícios que uma marca traz para uma companhia, com uma exposição mais detalhada sobre o aumento da lealdade e da qualidade percebida e em relação à possibilidade de cobrança de preço diferenciado.

\subsection{A marca}

A marca é um nome, termo, símbolo, design ou qualquer outra característica que identifique o produto ou serviço de um vendedor como distinto das ofertas dos seus concorrentes, sendo que essa coleção de imagens e idéias representa, implicitamente, experiências, valores, idéias e mesmo personalidade para o consumidor (AMA, 2009).

Esclarecendo a diferença entre o nome e marca, D’Emidio (2009, p. 10) afirma que um nome não tem associações, sendo simplesmente uma palavra. Um nome torna-se uma marca quando as pessoas o vinculam a outros elementos ou associações. Isto leva à idéia de que construir uma marca é mais do que simplesmente nomeá-la. Uma marca precisa ter uma direção estratégica, principalmente no que tange às associações que devem ser vinculadas ao nome ou símbolo e efetivamente diferenciá-lo.

Demonstrando consonância com esta definição, em 1955, Gardner e Ly escreveram um artigo na Harvard Business Review intitulado “O produto e a marca”, no qual já reconheciam que a marca é mais do que um nome utilizado para diferenciar fabricantes de produtos - é um símbolo complexo que representa várias idéias e atributos (KHAUAJA, 2005).

Além disso, esses autores afirmavam que os atributos funcionais dos produtos não seriam suficientes para diferenciar as marcas - seria necessário desenvolver atributos emocionais ou “de imagem”, os quais são criados pela propaganda e/ou em todas as comunicações associadas com o produto, incluindo sua embalagem (KHAUAJA, 2005).

O modo como a definição de marca é estabelecida pela American Marketing Association carrega uma dualidade, pois, conforme Kapferer (2004a), ela é um signo com a 
função de identificar e, ao mesmo tempo, diferenciar a fonte, dado que, de acordo com Lambin (2000), a marca diferencia a empresa dos seus concorrentes e informa ao mercado as qualidades distintivas que ela reivindica para seu produto, além da origem dele, tornando-se para o comprador um meio cômodo e prático de memorizar as características de um produto.

Assim, com uma combinação específica de atributos tangíveis e intangíveis, as marcas servem como sinais do posicionamento de produtos e companhias no mercado, permitindo aos consumidores criarem julgamentos e considerarem escolhê-los, em função das suas necessidades e situações de consumo, podendo produtos idênticos serem avaliados de formas diferentes, dependendo de como as marcas deles são estabelecidas (KOTLER; KELLER, 2006; LAMBIN, 2000).

A criação de uma representação da marca na mente dos consumidores desenvolve associações entre eles e a marca, que são a base do patrimônio da marca e podem ser relacionadas a atributos do produto, à celebridade que o anuncia ou a um símbolo particular. Associações com a marca são guiadas pela identidade com a marca - o que as organizações querem que a marca estabeleça na mente do consumidor (AAKER, 1996).

Assim, observa-se que as marcas estão mais ligadas ao processo de "ancoragem do produto”, ou seja, determinar os referenciais físicos e simbólicos no sentido de dar sustentação ao produto a tal ponto de poderem estabelecer a preferência por ele, não só influenciando o consumidor, como também determinando padrões de comportamento (KHAUAJA; PRADO, 2008). Portanto, o requisito da marca é o produto, com seus componentes tangíveis e intangíveis, e a função dela é revelá-lo (KAPFERER, 2004a).

Sintetizando essas considerações, Kapferer (2004b, p. 14) define a marca como "um sistema vivo composto de três elementos: um multissinal (nome, identidade gráfica, símbolo), associado a um (ou mais) produto(s)/serviço(s), ao(s) qual(is) é associada uma promessa de qualidade, segurança e pertinência a um universo”. Concordando que a marca é associada a uma promessa, Lambin (2000, p. 224) afirma que ela “é uma assinatura que identifica e responsabiliza o fabricante de uma forma duradoura, dado que se compromete a facultar ao comprador um nível de qualidade específico e constante”.

Esta idéia de que a marca é relacionada a uma promessa de qualidade - funcional ou emocional - e valor entregue enfatiza que ela deve ser uma síntese de todas as ações mercadológicas para satisfazer os desejos e necessidades específicas do consumidor, por meio da associação a uma série de atributos do produto, a uma expectativa de desempenho e a uma diferenciação em relação às marcas concorrentes. 
E, sendo uma promessa de qualidade criada na mente do consumidor, a marca pode gerar uma frustração caso o prometido não seja cumprido (KHAUAJA; PRADO, 2008). Assim, a marca acaba tornando-se um contrato econômico, em que o consumidor se compromete a pagar mais e permanecer fiel, a empresa aceita a obrigação de respeitar a todo o momento e em todos os lugares os seus compromissos de qualidade e a proteger a reputação dos signos da marca (KAPFERER, 2004b).

Portanto, a marca é o somatório das experiências vividas, do bom, do ruim, do feio e do que não faz parte da estratégia, constituindo-se em uma conexão simbólica e afetiva estabelecida entre uma organização, sua oferta material, intangível e aspiracional; e as pessoas para as quais se destina. Ela absorve conteúdo, imagens, sensações efêmeras. Torna-se conceitos psicológicos na mente do público mesmo que fugazmente, podendo ser apreciada, reconhecida e ocupar um lugar um pouco mais seguro na memória do consumidor. Como tal, não se pode controlá-la por completo. No máximo, é possível orientá-la e influenciá-la.

Essa conexão com as marcas abrange as dimensões sociais e psicológicas das pessoas, fazendo-as usarem as imagens e os significados de marca para confirmarem as suas identidades e construírem as imagens de si mesmas e do mundo, buscando significar uma experiência de vida e exprimir a sua diferença, originalidade e personalidade através das escolhas que efetuam e unirem-se em comunidades que são diferenciadas umas das outras (CALDWELL; COSHALL, 2002; LAMBIN, 2000; LEITCH; DAVENPORT, 2007). A relação dos consumidores com as marcas, escreve Ellwood (2004, p. 197), “atua junto aos valores de mais alto nível dos consumidores. São as convicções profundamente enraizadas que eles podem manter há muito tempo e geralmente se relacionam ao seu contexto pessoal de educação, classe ou raça”.

E, como há uma diversidade de identidades e imagens entre as pessoas no mundo, as empresas, afirma Lambin (2000, p. 224)

colocam no mercado produtos diferenciados não só nos atributos tangíveis, mas também nos aspectos distintivos emocionais, estéticos, sociais. Logo, as marcas permitem que os compradores exprimam sua diferença, que dêem a conhecer a sua originalidade, a sua personalidade através da escolha que efetuam. Nesta perspectiva, a marca é um meio de comunicação social que permite aos compradores, privilegiando certos atributos da sua escolha, dar a conhecer quem são e qual o seu sistema de valores.

Ao considerar-se o conceito de marcas junto com os inter-relacionamentos que ele possui com seus consumidores, percebe-se, de acordo com Perez (2004, p.13), que ambos 
formam um sistema com elementos constitutivos que vão desde seu nome, logotipo, forma, cores, até a publicidade que lhe dá sustentação e o discurso sociocultural dos executivos e da organização que lhe deu origem. Trata-se, assim, de um sistema bastante complexo, com componentes tangíveis e grande carga subjetiva e, portanto, de difícil controle e mensuração.

Sendo a marca um sistema, ela tende ao desgaste, pela sua suscetibilidade entrópica. Assim, deve-se sempre estar injetando recursos nas marcas, pois, caso contrário, elas começarão a perder força até desaparecerem. Dado que a marca é uma construção sociocultural, estes recursos são, principalmente, investimentos constantes em campanhas e ações mercadológicas para manter a marca sempre em evidência para o consumidor (PEREZ, 2004).

\subsubsection{A evolução do conceito}

A idéia de marca existe desde quando os homens passaram a ter uma designação verbal, o que se acredita ser muito antes do desenvolvimento da escrita. O nome representava uma marca pessoal, esta vinculada à idéia de distintividade, identidade, autoria e propriedade. Já nas tribos nômades tem-se a origem da assinatura das pessoas, com o objetivo de assinalar a propriedade de seu gado e de seus objetos. Vestígios de assinaturas foram descobertos em fragmentos de utensílios de barro procedentes da Idade da Pedra (PEREZ, 2004).

Mais tarde, na Antiguidade, este movimento de utilizar a assinatura como forma de assinalar propriedade tornou-se comum e produtores, escultores e artistas assinavam seus produtos, como forma de identificação. Isso foi necessário por causa da grande distância entre o produtor e o consumidor e as questões comerciais resultantes do aumento de importações e exportações, o que obrigaram o consumidor a confiar nas evidências da marca do produtor para assegurar-se que os produtos que estava comprando eram da mesma qualidade (ELLWOOD, 2004).

Posteriormente, com a queda do Império Romano do Ocidente, houve a interrupção do comércio entre as nações e o feudalismo passou a ser o modelo econômico-produtivo dominante na Europa Ocidental, marcando uma espécie de retorno a uma economia autosuficiente e fechada, praticamente de subsistência, dispensando o intercâmbio comercial entre os diferentes povos, o que influenciou para o desaparecimento do uso de signos como marcas (PEREZ, 2004). O abandono do uso da marca agravou-se, na Idade Média, durante o período histórico conhecido como "Idade das Trevas”, quando desapareceu a tradição de assinar 
trabalhos de arte, entre outros motivos, devido ao medo dos autores de serem perseguidos pela Igreja Católica.

Porém, com o crescimento das cidades, os feudos começaram a romper seu isolamento e os encontros comerciais tornaram-se mais frequentes, dando origem às primeiras lojas varejistas. Surgiram então as guildas artesanais ou corporações de ofício, destinadas a controlar a quantidade e a qualidade de produção, o preço e o processo de produção. Este controle era feito por meio das marcas de corporação, adicionadas em cada produto e que identificavam os produtores. As marcas tornaram-se, assim, uma proteção ao consumidor, que poderia identificar facilmente a origem da mercadoria comprada. Deste modo, as marcas voltam a ganhar importância nas transações comerciais, embora ainda possuíssem uma função meramente burocrática (ELLWOOD, 2004; KHAUAJA, 2005; KOTLER; KELLER, 2006).

Já o retorno do uso da assinatura como marca em trabalhos de arte só volta a ocorrer na Renascença, quando os artistas, começam a assinar as suas obras, acreditando que, com este ato, pudessem influenciar na avaliação do valor comercial delas (KHAUAJA, 2005; KOTLER; KELLER, 2006; PEREZ, 2004).

Com a Revolução Industrial, os mercados começaram a se tornar mais competitivos, devido à uniformidade manufaturada, e isto levou ao desenvolvimento de técnicas promocionais para atrair a atenção do consumidor, o que ampliou a importância da escolha de um signo para o produto, a fim de se criar a diferença baseada em imagem, e, dessa forma, deu-se início às marcas modernas (PEREZ, 2004).

Essa inovação mercadológica levou a maioria dos países industrializados a criar, na última década do século XIX, legislação específica sobre propriedade e proteção de marcas (KHAUAJA; PRADO, 2008). Nessa época, algumas empresas desenvolveram formas de distribuição em larga escala e começaram a utilizar meios de comunicação com ampla cobertura geográfica, visando atingir a massa populacional crescente, a fim de influenciar os consumidores nos padrões de pensamento, educação e tomada de decisão (ELLWOOD, 2004; KHAUAJA, 2005). Conforme Ellwood (2004, p. 21), “a década de 1890 foi a primeira época de ouro do moderno símbolo de marca. Foi durante esse período que algumas das marcas mais famosas do mundo foram criadas e anunciadas ao consumidor”.

No século XX, ampliando o seu papel nas empresas, a marca deixa a finalidade burocrática para assumir a responsabilidade de diferenciar os produtos e reduzir a importância do preço na decisão de compra, ao influenciar na percepção de valor dos produtos, assumindo, deste modo, a idéia de que a marca é um ativo que possui um potencial para gerar valor para os seus acionistas. 
Nesse contexto, em 1931, a empresa Procter \& Gamble criou o primeiro sistema de gestão de marcas, no qual times multifuncionais foram criados para gerir estas marcas como se fossem unidades de negócio, as quais dependiam de algumas operações compartilhadas, e o gestor de marca tendia a ser tático e reativo, observando os concorrentes e as atividades do canal, além das vendas e das tendências a fim de detectar possíveis problemas e corrigir a rota, quando necessário (AAKER; JOACHIMSTHALER, 2007).

Na década de 1980, devido à multiplicação de operações de fusões e aquisições nas quais as empresas eram avaliadas pelo mercado como possuindo um valor maior do que a soma dos seus ativos tangíveis, intensificou-se a discussão sobre o valor da marca, fazendo com que ela passasse a ser analisada em um enfoque econômico-financeiro, enquanto ativo intangível gerador de valor para seu proprietário (KHAUAJA; PRADO, 2008).

Contudo, nos anos de 1990, a marca, seu valor e sua forma de gestão foram colocados em xeque devido à proliferação de marcas genéricas e de primeiro preço, que evitavam gastos com comunicação, ao pegar carona nas campanhas publicitárias das grandes marcas, e brigavam com elas por meio do oferecimento de um único atrativo: baixos preços. Demonstrando conhecimento desse cenário, Aaker e Joachimsthaler (2007, p. 25) escrevem que “a pressão sobre os preços é causada pelas novas empresas que surgem no mercado, pelo excesso de capacidade, pela queda nas vendas e pelo poder do varejo. As quedas de preço, os descontos e/ou as promoções surgem logo depois”.

Assim, o surgimento das marcas genéricas fez com que as grandes empresas repensassem os seus gastos com ações de marketing, realocando as verbas de comunicação para as promoções de vendas, a fim de fazer frente às marcas genéricas e gerar resultados de curto prazo. Em 1983, as marcas norte-americanas investiram 70\% do seu orçamento de marketing em propaganda e 30\% em outras formas de promoção e, dez anos depois, essa proporção já havia se invertido para 25\% e $75 \%$ respectivamente, sendo que muito dessa inversão é devido ao aumento do investimento em promoções de vendas (KHAUAJA; PRADO, 2008).

Além da administração precária e reativa, outro motivo que foi determinante na mudança do destino das marcas foram as mudanças no mercado competitivo. Devido ao maior acesso às informações, o mercado consumidor tornou-se mais exigente, menos atraído por falsos apelos promocionais e mais fragmentado em termos de desejos e necessidades.

Também, devido à globalização e o desenvolvimento tecnológico, houve uma ampliação e acirramento da concorrência, o que exigiu uma taxa de inovação maior do que no passado. Outro fator que alterou o destino das marcas foi o crescimento do poder de barganha 
dos varejistas, que se tornaram maiores conhecedores dos seus clientes, devido à maior adoção da tecnologia da informação, e mais concentrados, devido às sucessivas fusões e aquisições executadas no setor.

Fica claro, então, que o mercado mudou em ritmo acelerado. E o sistema clássico de gestão de marcas da $P \& G$, que vinha funcionando bem há muitas décadas, mostrou-se ineficiente em dar conta das complexidades dos mercados emergentes, das pressões competitivas, das dinâmicas de canal, das forças globais, dos ambientes de negócios com marcas múltiplas, das extensões de marcas agressivas e das complexas estruturas de submarcas (AAKER; JOACHIMSTHALER, 2007).

Entretanto, muitas empresas demoraram a reagir e alterar a forma como gerenciavam suas marcas. Elas mantiveram as mesmas estruturas de marketing e seguiram as mesmas receitas do passado, sendo que o resultado foi a erosão do valor de suas marcas por meio de promoções de vendas e outras técnicas que buscavam resultados imediatos, mas que em nada tinham relação com a criação de valor para o consumidor (KHAUAJA, 2005).

Essa desconfiança em relação ao potencial das marcas fez com que a construção delas mudasse substancialmente, deixando de serem construídas ao longo de anos ou décadas, com base nos atributos dos produtos, por intermédio principalmente de propaganda, e passassem a serem criadas mais rapidamente, impulsionadas pela identidade de marca baseada em idéias ou estilos de vida (necessidades emocionais das pessoas e seus desejos de consumo), utilizando a propaganda apenas como um dos muitos fatores criadores de marcas e sendo este processo realizado num mundo altamente competitivo, o que aumenta a dificuldade de lograr a diferenciação. O gestor de marca agora tem um papel estratégico e visionário, deixando de ser apenas tático e reativo, e preocupa-se com o posicionamento e imagem da marca, a fim de comunicar a identidade da marca de forma consistente, eficiente e efetiva (AAKER; JOACHIMSTHALER, 2007).

Assim, enquanto as marcas clássicas perdiam mercado para as focadas em preços baixos, as empresas que seguiram essa nova forma de construir marcas se tornaram cada vez mais sólidas (KHAUAJA; PRADO, 2008). E são essas empresas bem sucedidas que formam a chamada "terceira onda das marcas” (KHAUAJA, 2005).

É neste momento que o conceito atual de marca consolida-se, quando ocorre o deslocamento do entendimento da relação do comportamento de consumo com as marcas de uma ótica essencialmente racional para uma ótica emocional, relegando a função do produto ou serviço e seus aspectos tangíveis para segundo plano. A marca passa a ser um signo capaz 
de adquirir significados múltiplos junto ao consumidor, passando para ele a posse da imagem da marca, que antes era do produtor (ELLWOOD, 2004).

Como consequência dessa mudança da importância dos atributos materiais para os abstratos, as dimensões espiritual, comportamental e ideológica da marca ganham um papel determinante no comportamento de compra dos consumidores. Eles passam a desejar conhecer além dos aspectos funcionais de um produto ou serviço e dos significados que podem ser transmitidos pela marca, eles querem agora saber em que a marca acredita (PRINGLE; THOMPSON apud KHAUAJA, 2008).

Confirmando este novo paradigma, Miranda (2006, p.38) escreve que

o consumidor não é [mais] orientado apenas pelo aspecto funcional. O seu comportamento é significativamente afetado pelos símbolos encontrados na identificação dos produtos. Os produtos que as pessoas compram são vistos pelos significados pessoais e sociais adicionados aos funcionais. Pessoas compram coisas não somente pelo que estas coisas podem fazer, mas também pelo que elas significam.

Nesta fase da história da marca, de acordo com Khauaja (2005, p. 39), além de identificar-se com a personalidade da marca e com seu estilo de vida, o consumidor começa a sentir-se membro de uma comunidade, a qual é formada pelo desejo do consumidor de compartilhar experiências e de sentir-se pertencente a um grupo com o qual tenha alguma afinidade. [...] Trata-se de uma comunidade explicitamente comercial, com alto grau de comprometimento com os valores do grupo.

Assim, a marca impulsiona a atitude de compra para um produto ou outro, conforme os seus significados expressos na sociedade onde o indivíduo interage, levando-o a adquirir produtos que façam o seu eu ser percebido como desejado pela comunidade que almeja participar (MIRANDA, 2006).

Por fim, esse culto à marca promovido pelas comunidades desperta também a cobrança de uma postura ética delas, característica da terceira fase das marcas, o que resulta no desenvolvimento de marcas sociais, relacionadas com os conceitos de responsabilidade social e boa governança corporativa. Um resumo de toda evolução da marca descrita nessa seção é apresentado na ilustração 1, a qual possui os principais pontos da história da marca. 


\section{Ilustração 1: Evolução da marca}

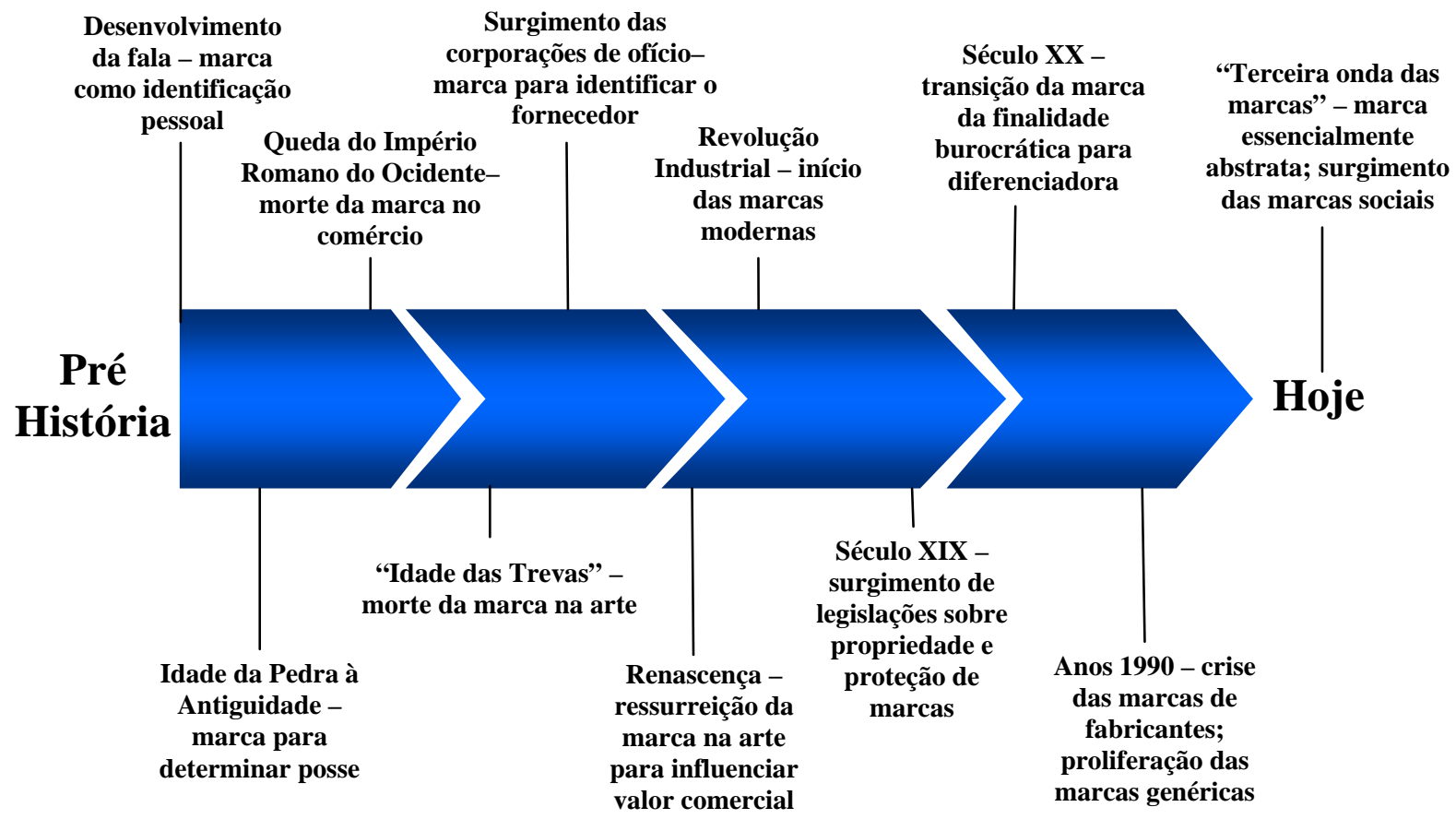

\subsection{Tipos de Marca}

Durante o movimento evolucionário da marca, alguns tipos de marca foram criados e, atualmente, eles co-existem no mercado. Dada essa grande variedade, para viabilizar o estudo dos tipos de marca, realizou-se a categorização deles em três grandes conjuntos de marcas: marcas genéricas/commodities, marcas de fabricantes e marcas sociais. Cada um dos três grupos é apresentado resumidamente no quadro 1 e detalhado a seguir. 


\begin{tabular}{|c|c|c|}
\hline Tipo de Marca & Característica & Exemplo \\
\hline Marca Genérica & $\begin{array}{l}\text { Possuem baixa identidade, pouca ou nenhuma } \\
\text { diferenciação e se posicionam no mercado como } \\
\text { produtos de baixo preço e de qualidade igual ou um } \\
\text { pouco inferior às marcas de fabricante. São marcas que } \\
\text { não fazem propaganda nenhuma. }\end{array}$ & $\begin{array}{l}\text { Produtos a granel ou com } \\
\text { marca somente para } \\
\text { identificar o fabricante }\end{array}$ \\
\hline Marca de Fabricante & $\begin{array}{l}\text { Possuem patrimônio construído sobre o seu know-how } \\
\text { tecnológico e das necessidades do mercado; são marcas } \\
\text { com tradição e reconhecimento entre os especialistas } \\
\text { do produto ou serviço em questão e entre os } \\
\text { consumidores, têm forte identidade, alta diferenciação, } \\
\text { investimento em comunicação, equipes dedicadas para } \\
\text { a gestão da marca, a fim de garantir o alto valor delas e } \\
\text { assegurar todos os benefícios que elas podem trazer. }\end{array}$ & $\begin{array}{l}\text { Hering, Banco Itaú, } \\
\text { Lacoste }\end{array}$ \\
\hline Marca Social & $\begin{array}{l}\text { É uma vertente das marcas de fabricante, assim, } \\
\text { compartilha das mesmas características, exceto pelo } \\
\text { fato de que, ao invés de ter patrimônio baseado em } \\
\text { avanço tecnológico e prestígio, estas marcas baseiam- } \\
\text { se no conceito da responsabilidade social, da produção } \\
\text { sustentável, com alto envolvimento com a natureza e a } \\
\text { sociedade. São, normalmente, marcas possuídas por } \\
\text { uma entidade sem fim lucrativo em parceria com uma } \\
\text { organização orientada pelo lucro e valor aos acionistas. }\end{array}$ & $\begin{array}{l}\text { Greenpeace, Banco Real, } \\
\text { Natura }\end{array}$ \\
\hline
\end{tabular}

\subsubsection{Marcas Genéricas ou ommodities}

As marcas genéricas ou commodities existem desde a invenção do comércio e reúnem as marcas que funcionam apenas como referência do produtor e os produtos sem marca (o que demonstra certa contradição, ao ser classificado como marca genérica), embora esse último esteja desaparecendo devido aos movimentos de defesa dos consumidores exigirem produtos assinados (LAMBIN, 2000).

São marcas que possuem uma baixa identidade, privada de valores imateriais e com pouca ou nenhuma diferenciação (acarretando menores custos de embalagem, de divulgação e de monitoramento), e que se posicionam no mercado como produtos de baixo preço e de qualidade igual ou um pouco inferior (mas, justa em relação ao preço pago) de outras marcas fortes (KAPFERER, 2004a; KAPFERER, 2004b). Conforme Kotler e Keller (2006), se a marca não possui diferenciais em relação aos concorrentes, ela pode ser classificada como uma commodity ou uma versão genérica do produto.

Ademais, são marcas que não fazem propaganda nenhuma, trabalhando na sombra da comunicação das marcas fortes ou beneficiando-se de comunicação institucional ou governamental (como ocorre no exemplo dos remédios genéricos). Ao trabalhar muito mais 
com o preço do que com os outros itens do composto de marketing, essas marcas confiam nos atacadistas e nos varejistas para encorajar os consumidores a comprá-las (CRAVENS, 1994).

Produto genérico tende a ter o objetivo de aumentar as margens dos canais distribuidores e proporcionar escolha de preço para os clientes. São produtos básicos e funcionais, normalmente com processo de produção simples e tecnologia básica atrasada com relação às marcas líderes de mercado.

O contrato implícito associado às marcas genéricas ou de primeiro preço é quantitativo e racional, trata-se de a empresa dar o máximo em troca do mínimo. A marca genérica luta contra a exclusão do consumo cotidiano ao compreender que o consumidor às vezes tem vontade de comprar, mas não possui dinheiro suficiente para comprar a marca de fabricante (KAPFERER, 2004a)

Uma descrição sintética, contudo, relevante, deste tipo de marca é feita por Perez (2004, p. 11) ao afirmar que

sem marca, um produto é uma coisa - uma mercadoria, um saquinho de café, um calçado ou uma latinha de molho. Para a maioria das categorias de produtos, a percepção que o consumidor tem de um produto genérico, sem marca, tende a ser dominada pela condição de coisa do produto, por seus atributos e benefícios meramente funcionais, desprovendo-o de sua carga emocional.

A mesma autora (2004, p. 42) divide as marcas genéricas em dois grupos:

1) as marcas que são genéricas a partir de sua concepção, como goiaba, marmelada e outros itens que não apresentem qualquer sinal que os diferencie; 2) as marcas que se tornaram genéricas por sua “vulgarização” ou popularização, como “tênis”, marca originalmente registrada pela São Paulo Alpargatas, que perdeu seu direito à proteção por ter ingressado no linguajar popular como sinônimo de “calçado esportivo”.

O caso da "vulgarização" da marca beneficia a empresa ao transformar a marca em sinônimo de categoria; porém, ao mesmo tempo, a empresa tem prejuízos pelo fato de que a marca perde identidade por não apresentar nenhum elemento diferenciador que transforme a sua marca em única, passando agora todos os concorrentes a desfrutarem das mesmas associações da marca sinônimo de categoria (PRADO; FARINHA, 2008)

As marcas genéricas alcançaram a maturidade e expressam o alto nível de responsabilidade na década de 70, quando grandes empresas varejistas, como Ahold, Cotsco e Carrefour, passaram a se expandir internacionalmente, promovendo uma consolidação do setor de varejo, o que resultou, por volta de vinte anos depois, no acirramento da competição 
por preços, guiado por: maior poder de barganha e de mercado dos varejistas, clientes sensíveis a preço, crescimento reduzido das categorias e excesso de capacidade (AAKER, 1996; ELLWOOD, 2004; KUMAR; STEENKAMP, 2008).

O sucesso das marcas genéricas chegou a colocar em questão a efetividade da gestão e o valor das marcas de fabricante, levantando a dúvida se não seria mais eficiente utilizar todo o orçamento de comunicação para fazer promoções de vendas das marcas fortes, a fim de conseguir competir em preço com as marcas genéricas.

As categorias de produtos maduras são os principais campos de proliferação das marcas genéricas, pois, com o maior conhecimento do consumidor sobre o produto, este se torna “transparente”, ou seja, os sinais de qualidade tornam-se acessíveis e mensuráveis, isso reduz a esfera imaterial e a insubstituibilidade da marca e o envolvimento do consumidor na compra, tornando o preço o critério discriminante das marcas (KAPFERER, 2004a; KAPFERER, 2004b). Segundo a pesquisa da Nielsen, nos mercados de bebidas alcoólicas e de mercearia salgada, as marcas genéricas são as preferidas, pois são as mais baratas (NUNES, 2008).

No Brasil, os produtos sem marca, relatam Prado e Farinha (2008, p. 42-43), tiveram destaque maior após o Plano Real, em 1994, quando a economia foi estabilizada e, em um primeiro momento, as classes de baixa renda puderam ter acesso à compra de produtos que antes eram privilégios das classes econômicas A e B. [...] Tudo isso deu força para a ascensão das marcas de primeiro preço, ou marcas populares, também conhecidas pelo nome $B$-brands, ou até mesmo marcas talibãs, as quais se caracterizam por produtos de preço baixo e qualidade aceitável, predominantemente nos setores de alimentos, de bebidas, de higiene pessoal e de limpeza.

Contudo, o segmento em que este tipo de marca encontra o seu maior sucesso, no país, é no farmacêutico, onde durante o governo do ex-presidente Fernando Henrique Cardoso (1994-2002), criou-se a oportunidade de ter acesso à compra de remédios genéricos, ou seja, remédios conhecidos pelos seus nomes científicos os quais possuíam preços até 80\% menores do que os preços das marcas de fabricante (KHAUAJA; PRADO, 2008). Também, esses remédios genéricos contavam com uma propaganda governamental em nível nacional, a qual era estrelada pelo então ministro da saúde, José Serra, que foi quem “lutou” pela implantação dos genéricos no segmento farmacêutico.

Devido à associação da marca genérica à idéia de vantajosa relação preço-qualidade, ao escolhê-la, o consumidor pode sinalizar, mesmo que sem intenção, que é uma pessoa racional nas compras e na gestão do dinheiro (ELLWOOD, 2004). Afinal, segundo Caldwell e Coshall (2002, p. 383), "todo tipo de escolha de compra em produtos e serviços carrega 
significados que têm sido incorporados nas marcas que consumimos. [...] É difícil evitar as associações que têm sido anexadas às marcas”.

\subsubsection{Marcas de Fabricante}

As marcas de fabricante ou conceituais são, basicamente, as marcas top of mind ou referenciais, caracterizadas por possuírem um patrimônio construído sobre o seu know-how tecnológico e das necessidades do mercado; são marcas com tradição e reconhecimento entre os especialistas do produto ou serviço em questão e entre os consumidores. Normalmente, elas possuem celebridades ou especialistas endossando-as para confirmar as afirmações de autoridade ou desempenho e, desse modo, propõem uma relação de confiança com o consumidor, ao transmitir a idéia de que elas fazem a boa escolha por ele, por isso elas são a sua boa escolha (ELLWOOD, 2004; KAPFERER, 2004a).

Além disso, essas marcas têm forte identidade e, consequentemente, alta diferenciação; têm como característica o investimento de grandes quantias de dinheiro em comunicação e o uso de equipes dedicadas para a gestão da marca, a fim de garantir o alto valor delas e assegurar todos os benefícios que elas podem trazer. Essa forte identidade da marca tende a aumentar a intensidade do vínculo com o consumidor, dando-lhe profundidade emocional e tornando-a menos substituível (KAPFERER, 2004a). A falta de uma forte identidade, segundo Kapferer (2004a, p. 45), é o que

\footnotetext{
faz com que muitos medicamentos não sejam marcas. Para os laboratórios farmacêuticos, todo medicamento se reduz à sua substância. A construção de um valor agregado que, longe de substituir a superioridade do produto, lhe daria uma identidade mais forte, mais ressonância, ainda é rara.
}

Este é o tipo de marca que tem sido difundido desde a antiguidade, quando os artesãos acreditavam que ao assinarem as suas obras, poderiam influenciar no valor delas; até hoje, quando as marcas que utilizam o nome do fabricante passaram a serem consumidas como símbolos de aspirações, imagens e estilos de vida (PEREZ, 2004; KUMAR; STEENKAMP, 2008).

A relação da marca de fabricante com o consumidor pode ser caracterizada como um contrato implícito especial, porque, de acordo com Kapferer (2004a, p. 44),

a marca forte possui, além de um produto e um serviço eficientes, um verdadeiro imaginário de marca, uma simbólica, seu consumo é tanto do produto como do símbolo. Consumimos a sua identidade em todas as suas facetas: 1) o físico da marca, seu produto, seu desempenho, seus serviços associados; 2) sua personalidade, 
levada ou não por um ícone de marca que estimula seu potencial simbólico; 3) seus valores [...]; 4) a relação proposta.

A existência da marca de fabricante pode ser explicada pela teoria da auto-congruência de Sirgy (apud MIRANDA, 2006, p. 65), a qual afirma que “consumidores preferem produtos e marcas com significados que são consistentes com seus auto-conceitos; assim sendo, motivados por auto-consistência, consumidores comparam seus auto-conceitos com a imagem dos produtos e preferem produtos cujas imagens são congruentes com suas auto-imagens”.

E, complementando a teoria de Sirgy, Ellwood (2004, p. 154) afirma que "na outra extremidade do espectro da identidade fica a imagem social que todos espelhamos aos nossos amigos, à família, aos colegas de trabalho e outras pessoas de nossas relações; [sendo que] essa imagem pode ser igual à nossa auto-imagem [, a qual normalmente reservamos para nossos conhecidos mais íntimos]”. Assim, sintetiza Kapferer (2004a, p. 44), construímos “a nossa própria identidade [e imagem] por meio [...] da identidade [e imagem] da marca: o reflexo (em relação ao exterior) e a mentalização (que valoriza o nosso self-concept)”. E, para estabelecer as suas imagens externas e a interna, a pessoa necessita observar as marcas de bens e serviços que são consumidas em suas situações cotidianas de uso.

Aliada à teoria de construção da identidade a partir das marcas que se consome, a crença de que os benefícios racionais geralmente propiciam apenas as condições de entrada para interessar a um consumidor, sendo que a escolha será feita com base nos benefícios emocionais que diferenciam as marcas, e de que as marcas de fabricante geram lealdade dos consumidores e, deste modo, abrem a possibilidade de cobrar preços premium (garantindo maiores margens), de ampliar a percepção do valor entregue e de serem criadas comunidades de pessoas engajadas que façam a comunicação boca-a-boca da marca (reduzindo-se a necessidade de gastos com comunicação); é um ponto vital que garante a sustentação dessa categoria de marcas (ELLWOOD, 2004).

Dado que, segundo Ellwood (2004, p. 260), marcas de fabricantes “são uma vasta gama de marcas que satisfazem as necessidades psicológicas e sociológicas dos clientes por uma identidade pessoal ou status e por uma identidade de grupo ou filiação”, elas são viáveis em produtos que podem ser diferenciados, ou seja, que podem ser ligados a atributos intangíveis, como experiências e emoções, que vão além das características físicas e funcionais do produto, em outras palavras, são produtos que possuem atributos subjetivos de difícil avaliação.

Uma prova disto é a pesquisa da Nielsen, a qual relata que entre os bens de consumo, somente na categoria de produtos de higiene pessoal é que as marcas de fabricante são 
preferidas (NUNES, 2008). Isto ocorreu provavelmente devido à complexidade dos produtos desta categoria, o que os torna de difícil avaliação, e ao alto risco à segurança física e emocional que esses produtos possuem, tornando, desse modo, o consumidor sensível à possível baixa qualidade de produtos genéricos e com preço baixo.

\subsubsection{Marcas Sociais}

A criação deste grupo de marcas é recente, datando do fim da década de 1990, com a consolidação do conceito de responsabilidade social corporativa (RSC), embora, segundo Bronn e Vrioni (2001), esse conceito tenha sido desenvolvido em 1960 nos EUA, decorrente do ceticismo e descontentamento com a postura adotada pelas empresas e da noção de que elas têm responsabilidades que vão além das suas obrigações legais.

Esse movimento de responsabilidade social corporativa acabou moldando o conteúdo das marcas, pois diferentes stakeholders e, em particular, consumidores, estão exigindo cada vez mais das empresas, demandando não somente produtos e serviços com alta qualidade e preço baixo, mas, também, uma postura ética e responsável das empresas, o que culminou na formação das marcas sociais, que são as marcas com uma dimensão "humana” ou "espiritual”, as quais são desenvolvidas no nível global do comportamento da organização e não só do produto ou da sua linha (ALCAÑIZ et al., 2010; ELLWOOD, 2004; MORT. et al., 2007; MAIO, 2003; SUBRAHMANYAN, 2004).

O grupo das marcas sociais ou marcas éticas é uma vertente das marcas de fabricante; assim, compartilha das mesmas características do grupo anterior, exceto pelo fato de que, ao invés de posicionarem-se como altamente tecnológicas e de prestígio, têm seu patrimônio baseado no conceito da responsabilidade social e financeira, da produção sustentável, com alto envolvimento com a natureza e a sociedade. De acordo com Leitch e Davenport (2007), as causas sócio-ambientais podem servir de veículo para a expressão da identidade pessoal e unir os seus adeptos em comunidades que se diferenciam umas das outras.

São, normalmente, marcas possuídas por uma entidade sem fim lucrativo em parceria com uma organização de bens ou serviços direcionada pelo valor aos acionistas, que, de acordo com Lafferty e Goldsmith (2005), se beneficiam da aliança devido ao aumento das associações positivas e do conhecimento tanto da causa quanto da marca. Nesses casos, a fidelidade do consumidor pode ser à marca social ao invés de a uma organização particular, visto que múltiplas organizações podem estar associadas para desenvolver essa marca (LEITCH; DAVENPORT, 2007). 
A explicação para o interesse de as entidades sem fim lucrativo participarem dessas parceiras é de que ao atuarem em um ambiente mais competitivo e com recursos mais escassos, elas tornaram-se cientes da importância do branding para realizar o financiamento das suas operações, dado que ele tem o poder de moldar as atitudes e ações dos stakeholders por meio da imagem da marca, construindo a confiança deles na entidade, alinhando-se às suas necessidades psicológicas e desejos e comunicando os pontos de diferença da entidade para eles e potenciais doadores (EWING; NAPOLI, 2005).

Essa tarefa de comunicação desempenhada pela marca é importante para as organizações sem fim lucrativo, pois, como competem pelo interesse e afeição do público e não oferecem produtos tangíveis para venda, mas sim serviços e ideais intangíveis, os doadores acabam precisando da marca para entender a missão dessas entidades e os benefícios sócio-ambientais de contribuir com uma delas (KHAN; EDE, 2009; VENABLE et al., 2005).

Basicamente, o conceito de marketing social estabelece a comunicação da empresa, por meio de propaganda, embalagens, promoções e outros meios, da sua responsabilidade social corporativa, como a sua afiliação ou trabalho em conjunto com uma organização sem fins lucrativos ou suportando uma causa (BRONN; VRIONI, 2001).

Assim, a marca social pode ser definida como um processo de formular e implementar um conceito de marca que é caracterizada pela contribuição a um determinado esforço que gera lucro social, ou seja, benefícios sociais, ambientais e/ou humanitários; o qual, por sua vez, leva os consumidores a engajarem-se em uma transação geradora de receita para a empresa (GILLIGAN; GOLDEN, 2009).

As marcas sociais normalmente baseiam os seus apelos em uma ou mais das seguintes áreas: meio ambiente, comunidade, bem estar, diversidade, direitos humanos, desempenho financeiro responsável e justo e governança corporativa (BLOMQVIST; POSNER, 2004; BRONN; VRIONI, 2001; POLONSKY; JEVONS, 2006).

Estas marcas se apóiam nas mesmas crenças das marcas de fabricante; contudo, as empresas que as adotam têm pelo menos um objetivo não-econômico relacionado ao bemestar social e, para atingí-lo, usam recursos da empresa e/ou de um de seus parceiros, pois confiam que o consumidor está disposto a pagar mais por marcas que respeitam todo o sistema sócio-ambiental que elas afetam. Conforme observa Ellwood (2004), usar as questões ideológicas contemporâneas, tais quais as sociais e ambientais, como uma essência da personalidade de uma marca pode atrair um grupo grande e crescente de consumidores que tenham convicções semelhantes. 
Estudos mostram que as marcas sociais afetam a percepção do consumidor e influenciam as suas atitudes em direção aos produtos que as usam, assim como melhoram a avaliação feita por eles dos produtos e das companhias que possuem essas marcas (HOEFFLER; KELLER, 2002; LAFFERTY; GOLDSMITH; HULT, 2004; PRACEJUS et al., 2004).

Porém, Subrahmanyan (2004) observou que as marcas sociais são mais prováveis de serem compradas no caso de itens práticos - aqueles consumidos rotineiramente - do que para hedônicos - os quais são ocasionalmente comprados e fortemente influenciados pelos significados e conceitos criados pelas marcas. No mesmo sentido, Ellwood (2004, p. 200) relata que as preocupações sócio-ambientais podem ser

\begin{abstract}
um elemento de insatisfação em relação à marca junto ao grupo alvo que deseje produtos de luxo. Esses consumidores desejam se agradar sem ficar com a consciência culpada. Eles podem se satisfazer no plano pessoal, sem a necessidade de equilibrar os seus desejos com a norma. As empresas que têm uma forte postura ambiental [e social] podem ser consideradas enfadonhas ou politicamente corretas demais por alguns consumidores. [...] Os consumidores podem associar negativamente as marcas [sócio-] ambientais com grupos com estilo de vida alternativos que são indesejáveis.
\end{abstract}

O uso da RSC pelas empresas veio como solução para ajudar a criar uma identidade de marca forte e significativa para o consumidor, a fim de diferenciá-la dos competidores e assegurar o seu valor simbólico e personalidade, dado que está difícil para diferenciar a marca usando atributos tradicionais como preço, valor ou qualidade (ALCAÑIZ et al., 2010; POLONSKY; JEVONS, 2006).

Algumas influências da marca social são obter benefícios organizacionais de curto e longo prazo mediante práticas socialmente responsáveis e melhorar a imagem da marca, ao demonstrar motivações altruístas (ALCAÑIZ et al., 2010; WYMER; SAMU, 2009). Hoeffler e Keller (2002) citam ainda que a marca social possibilita construir ligações emocionais, até mesmo espirituais, com os consumidores, ajuda a dirimir críticas e superar publicidade negativa advinda de um evento inesperado ou tragédia.

Já Bronn e Vrioni (2001) relatam que a associação com uma empresa sem fins lucrativos pode gerar cobertura de mídia positiva, construir uma reputação de compaixão e caridade para uma empresa, melhorar sua integridade e reduzir os efeitos negativos do ceticismo dos consumidores, aumentar a motivação e produtividade dos empregados e as preferências do público, fortalecer os relacionamentos com stakeholders internos e externos, cujos suportes são vitais para o patrimônio da marca e, em último caso, afetam o bottom line da empresa. 
O princípio que sustenta o uso de marca social é a possibilidade de transferir os valores da causa social ou ambiental para a marca e, desse modo, posicionando-a como socialmente responsável e criando para a marca associações únicas no mercado (ALCAÑIZ et al., 2010; LEITCH; DAVENPORT, 2007). Quanto mais os consumidores percebem convergência ou similaridade da causa com a marca, maior é a probabilidade de os consumidores inferirem associações similares para a marca (HOEFFLER; KELLER, 2002).

Porém, para ser bem sucedida, a marca social precisa superar o ceticismo inicial dos consumidores, transmitindo uma real motivação altruísta. Para reduzir essa tensão com os consumidores, conforme Alcañiz et al. (2010), a credibilidade da empresa na associação com as causas sociais é a chave, sendo que quanto mais confiança o consumidor tem na empresa, maior é o número de respostas positivas para as associações da marca com a causa social.

Para possuir uma alta credibilidade perante os consumidores, a aliança entre a marca e a causa deve possuir convergência funcional - conexão entre os atributos e funções da categoria de produtos da empresa e o tipo de causa social patrocinada - e convergência de imagem - ligação entre as associações da marca com a imagem da causa defendida, sendo que quando há coerência entre a marca e a causa apoiada, o consumidor tem menos desconfiança sobre os interesses das empresas com essa aliança (ALCAÑIZ et al., 2010).

No Brasil, é cada vez maior o número de empresas que estão posicionando as suas marcas nesta categoria; entre elas, tem-se a Petrobrás, o banco ABN Amro Real (recentemente adquirido pelo banco Santander), a empresa de calçados e têxteis Góoc e as de bens de consumo Natura e Unilever (com a Campanha pela Real Beleza, da marca Dove).

Nos EUA, segundo Blomqvist e Posner (2004), o varejista de alimentos naturais Whole Foods possui uma marca que promete sustentabilidade, sendo que a estratégia da empresa estabelece padrões para os produtos que ela vende (todos naturais e de criação sustentável, sendo banido qualquer produto com ingrediente artificial), o modo como ela vende e o modo como ela trata os empregados.

Ademais, é possível encontrar empresas sem fins lucrativos com marcas sociais fortes, como Greenpeace, Cruz Vermelha, Médicos Sem Fronteiras e WWF (World Wildlife Fund, que, entre outras ações, licenciou a sua marca para uma linha de animais de pelúcia da empresa de brinquedos Gulliver), que as utilizam para comercializar produtos, a fim de levantar fundos para sustentar as suas atividades e estrutura (MORT et al., 2007).

Também, há casos de fracasso no uso de marca social, como o ocorrido com as empresas como a Shell, Coca-Cola e British American Tobacco, que tiveram problema em posicionar a marca como social e não conseguir entregar o que foi prometido no 
posicionamento da marca (BLOMQVIST; POSNER, 2004). No caso da Shell, enquanto a sua marca comunicava a idéia de que somente se agir de maneira responsável uma companhia pode ser lucrativa, a empresa era criticada pelo comportamento impróprio dos seus executivos de alto escalão e acusada de falsamente posicionar-se como uma boa “vizinha”, pois deixava petróleo vazar sem os devidos cuidados e tinha programas muito ineficientes para o desenvolvimento das comunidades (BLOMQVIST; POSNER, 2004).

O Instituto Akatu, uma organização não-governamental (ONG) cuja missão é disseminar o comportamento responsável entre os consumidores brasileiros, descobriu, de acordo com Almeida (apud Khauaja, 2005), que atitudes como o cuidado de não poluir o meio ambiente e oferecer um bom atendimento ao consumidor já não são mais vistas pelo consumidor consciente como um diferencial das marcas. Estes consumidores acreditam que isso já é obrigação das empresas, demonstrando que as exigências dos consumidores com questões sociais e ambientais tende a crescer.

A mesma organização levantou que $37 \%$ dos brasileiros admitem a possibilidade de pagar mais por um produto ou serviço de uma empresa que realize projetos em favor do meio ambiente (PRODUTOS, 2008). Já um estudo realizado pela empresa Letshal, com 24 mil pessoas em 16 países, apontou que 64\% dos respondentes preferem marcas sociais, sendo que 74\% disseram que ajudar os outros traz significado para suas vidas (MAGALHÃES, 2011). E, pesquisas citadas por Bronn e Vrioni (2001) e Lafferty e Goldsmith (2005) mostram que muitos consumidores preferem empresas e produtos socialmente responsáveis.

Nos EUA, um terço da população disse que, após preço e qualidade, as práticas comerciais responsáveis de uma empresa são os fatores mais importantes na decisão de se comprar uma marca e, se o preço e a qualidade são iguais, eles são mais propensos a adquirir uma marca que tenha um benefício de marketing relacionado a uma causa social (BRONN; VRIONI, 2001). Na Ásia, as companhias que atuam no mercado business-to-business constataram que os compradores estão preferindo fornecedores que demonstram causar danos mínimos ao meio ambiente e à sociedade (DARNALL, 2008).

Entretanto, uma das dificuldades das marcas sociais é provar que elas realmente são sociais, pois, em alguns países, como o Brasil, não há certificação oficial para produtos sócioambientalmente responsáveis. Essa assimetria de informação dificulta a eficiência de mercado, sendo que consumidores que desejam consumir marcas sociais mantêm ceticismo perante elas e pessoas que desejam investir em negócios sociais têm dificuldade de identificálos (DARNALL, 2008).

Para contornar esse problema, Ellwood (2004, p. 201-202) escreve que 
as marcas geralmente usam algumas formas de endosso para confirmar as afirmações de autoridade ou desempenho da marca. [...]. A autoridade pode ser sustentada pelo credenciamento junto a uma organização profissional [ou] institucional [...]. Esse credenciamento sugere uma avaliação independente que pode ser separada das próprias alegações de desempenho do fabricante. Os consumidores apreciam esse tipo de orientação independente como um método de distinguir entre as marcas. Esses credenciamentos são muitas vezes apresentados graficamente como selos de aprovação ou assinaturas de credenciamento na embalagem ou em material promocional. [...] [Outro caminho] para o endosso é usar uma relação de referência entre duas empresas reconhecidas como especialistas nos próprios campos de atuação.

Assim, para construir uma marca social sem endosso e a parceria de uma entidade sem fim lucrativo, as empresas têm adotado comprometimentos unilaterais e/ou participação em programas voluntários sócio-ambientais. A primeira iniciativa consiste em esforços autoiniciados e auto-promovidos pelas empresas para proativamente endereçar seus impactos sócioambientais; porém, por não possuir uma entidade externa fiscalizando as atividades executadas, essa opção acaba resolvendo o problema da falta de informação sobre as ações da marca social, mas sofre da baixa credibilidade por falta de legitimidade externa (DARNALL, 2008).

Já os programas voluntários sócio-ambientais são conjuntos de códigos, acordos ou comprometimentos que encorajam as empresas a reduzir voluntariamente seus impactos sociais e ambientais e são desenvolvidos e patrocinados pelo governo, associações industriais ou entidades sem fim lucrativo, que determinam os objetivos do programa e subseqüentemente recrutam empresas que aceitam aderir aos padrões dele (DARNALL, 2008).

Quadro 2: As abordagens de desenvolvimento de marcas sociais.

\begin{tabular}{|c|l|l|l|l|}
\hline $\begin{array}{c}\text { Características do } \\
\text { programa }\end{array}$ & \multicolumn{1}{|c|}{$\begin{array}{c}\text { Abordagem } \\
\text { unilateral }\end{array}$} & \multicolumn{2}{|c|}{ Participação em programas voluntários sócio-ambientais } \\
\cline { 2 - 5 } $\begin{array}{c}\text { Objetivos sócio- } \\
\text { ambientais }\end{array}$ & $\begin{array}{l}\text { Estabelecido } \\
\text { internamente. }\end{array}$ & $\begin{array}{l}\text { Estabelecido } \\
\text { externamente. }\end{array}$ & $\begin{array}{l}\text { Estabelecido } \\
\text { externa } \\
\text { internamente. }\end{array}$ & $\begin{array}{l}\text { Estabelecido e } \\
\text { externa } \\
\text { internamente. }\end{array}$ \\
\hline Comunicação & $\begin{array}{l}\text { Auto-promoção } \\
\text { através de website e } \\
\text { materiais } \\
\text { corporativos. }\end{array}$ & $\begin{array}{l}\text { Auto-promoção } \\
\text { mais promoção } \\
\text { externa de } \\
\text { patrocinadores do do } \\
\text { programa. }\end{array}$ & $\begin{array}{l}\text { Auto-promoção } \\
\text { mais promoção } \\
\text { externa de } \\
\text { patrocinadores do } \\
\text { programa. }\end{array}$ & $\begin{array}{l}\text { Auto-promoção } \\
\text { mais promoção } \\
\text { externa de } \\
\text { patrocinadores } \\
\text { do programa. }\end{array}$ \\
\hline Custo & $\begin{array}{l}\text { Determinado pela } \\
\text { empresa. }\end{array}$ & Baixo. & Alto. & Moderado. \\
\hline $\begin{array}{l}\text { Legitimidade } \\
\text { externa }\end{array}$ & Baixa. & Moderada. & Moderada à alta. \\
\hline
\end{tabular}

Fonte: Adaptado de Darnall (2008) 
Esses programas podem ser: 1) auto-monitorados, quando os participantes determinam sua conformidade aos objetivos do programa e comunicam aos patrocinadores; 2) certificados por terceiros, onde se utiliza auditoria de terceiros independentes para assegurar a conformidade com os objetivos do programa; ou 3) híbridos, que seriam uma mescla das duas primeiras opções. As marcas que participam de programas certificados por terceiros desfrutam de maior legitimidade e credibilidade e têm maiores gastos do que as que seguem iniciativas auto-monitoradas, as quais são mais bem percebidas pelos consumidores em relação aos comprometimentos unilaterais (DARNALL, 2008). O quadro 2 faz um resumo dessas iniciativas.

Portanto, o uso de marcas sociais é muito sensível à desconfiança e crítica popular; por isso, as empresas devem tomar cuidado quando utilizá-las, pois, atividades promocionais muito exuberantes podem ser vistas como oportunistas e gerar dano reputacional (POLONSKY; JEVONS, 2006). Simplesmente falar em responsabilidade social não é suficiente, as marcas sociais necessitam ser suportadas por práticas empresariais e comunicação interna e externa consistente e clara, além de serem vivenciadas de maneira tangível pelos consumidores (BLOMQVIST; POSNER, 2004; POLONSKY; JEVONS, 2006).

\subsection{Construção de uma marca}

Por meio da sua capacidade de carregar e transmitir significados, as marcas que consumidas moldam as vidas das pessoas e, portanto, é necessário sintonizá-las com os seus interesses e desejos, a fim de se gerarem vivências da marca excitantes e qualitativas (ELLWOOD, 2004: 152).

A gestão de marcas, ou branding, é o conjunto de ações de marketing que envolvem a criação de estruturas mentais e que auxiliam o consumidor a organizar o seu conhecimento sobre os produtos e serviços de um modo que clarifique a sua tomada de decisão e, no processo, forneça valor para a empresa (KOTLER; KELLER, 2006, p. 270). A chave para o branding é alcançar o emocional do consumidor (e lá permanecer), com o objetivo que ele perceba a diferença entre as marcas na categoria de produtos.

Com base em Aaker e Joachimsthaler (2007), Kotler e Keller (2006) e Keller (2002), a construção de uma marca é apresentada neste trabalho como um ciclo estruturado de seis fases interligadas sequenciais, conforme a ilustração 2. Para fins de comparação do modelo elaborado, a estrutura proposta por Keller (2002) considera que o primeiro passo é a decisão de criar ou não a marca e, optado pela construção, os quatro passos subsequentes são: 
- Garantir a identificação da marca com os clientes e a associação dela, em suas mentes, com uma categoria de produtos específica ou com alguma(s) necessidade(s) dos clientes;

- Estabelecer a totalidade do significado da marca na mente dos clientes, criando uma ligação entre as associações tangíveis e intangíveis da marca com determinadas propriedades;

- Verificar as respostas dos clientes à identidade e ao significado da marca;

- Converter a resposta à marca em um relacionamento intenso e ativo de lealdade entre os clientes e a marca.

\section{Ilustração 2: Etapas de construção de uma marca}

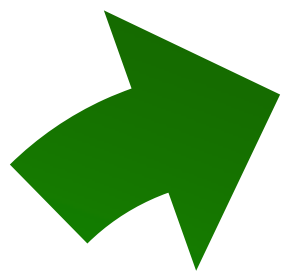

\section{Segmentação}

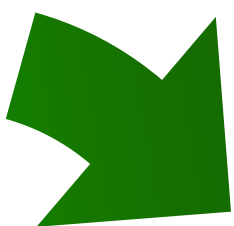

Avaliação da Marca

Arquitetura

de Marca
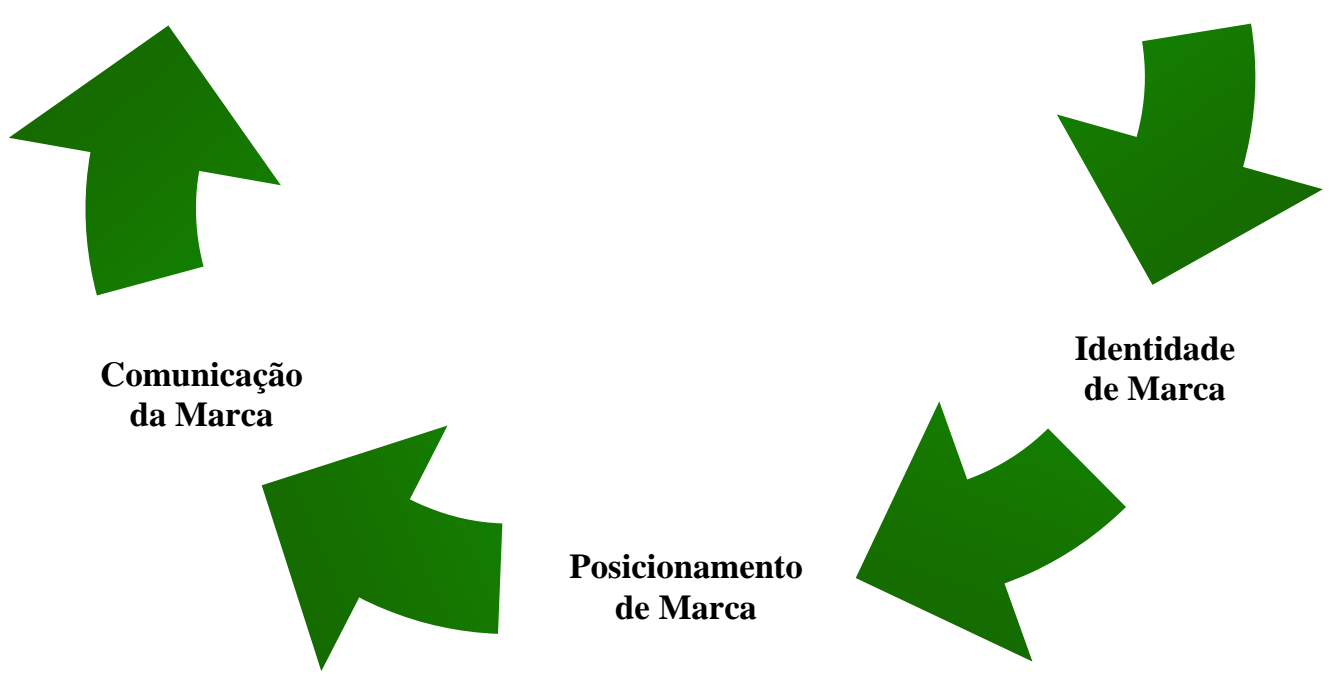

Posicionamento de Marca

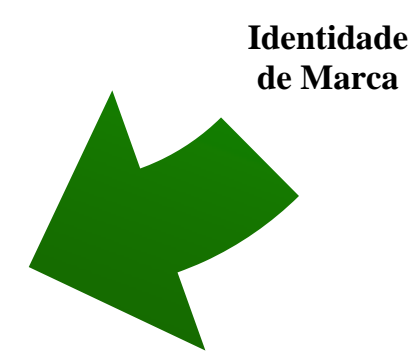

Estes quatro passos sequenciais são os fundamentos para desenvolver, respectivamente, a identidade da marca, o significado dela, os sentimentos e atitudes em relação a ela e o relacionamento com a marca (KELLER, 2002). 
O ciclo de construção de marca elaborado nesse trabalho contempla não só a criação, mas, também, o desenvolvimento posterior dela e, desse modo, se repete ao longo da vida de uma marca, o que demonstra que as decisões são reavaliadas ao longo do tempo, podendo ser alteradas ou não e transmite a idéia de que o desenvolvimento da marca é um processo de aperfeiçoamento ao longo do tempo. Nos primeiros ciclos, ou seja, no início da vida, a marca é pouco conhecida, não tem imagem, não influencia os compradores ou então impacta as suas decisões de forma leve, sendo que o produto acaba carregando a marca ao tê-la associada apenas às suas vantagens materiais (KAPFERER, 2004a; KAPFERER, 2004b).

Conforme os ciclos vão se sucedendo e a marca vai ganhando maturidade, a sua distribuição e o investimento em promoção aumentam, o que leva a marca a desenvolver associações mentais nos consumidores e a evocar valores imateriais - como estilos de vida, valores, comportamentos, idéias - que resultam em maior notoriedade, imagem, consciência e impacto na preferência do consumidor, invertendo-se, dessa forma, a relação inicial de dependência entre a marca e o produto (KAPFERER, 2004a; KAPFERER, 2004b). Assim, durante os seus ciclos de desenvolvimento, conforme as marcas vão aumentando o seu valor, elas passam do material ao imaterial, ou seja, do tangível para o intangível. A seguir, são descritas as seis etapas em que foi dividido o processo de construção de uma marca.

\subsubsection{Segmentação}

Na sociedade moderna, onde os produtos e serviços passam a ser consumidos por causa dos significados transmitidos por suas marcas e os mercados mostram sinais de fragmentação em micro-segmentos, é quase impossível para as empresas satisfazerem todos os compradores com uma marca padrão. Dado que a identidade que os consumidores cultivam e a imagem que desejam transmitir variam entre as pessoas de acordo com o tempo, as circunstâncias e os seus interesses e experiências, elas criam segmentos de mercado e levam as empresas a abandonar as estratégias de marketing de massa para focar em grupos de consumidores que tenham afinidade com as suas marcas (CRAVENS; PIERCY, 2007; ELLWOOD, 2004; LAMBIN, 2000).

A segmentação possui como objetivo a identificação dos grupos de consumidores-alvos e, assim, consiste em reunir os consumidores em grupos homogêneos internamente e heterogêneos externamente segundo um conjunto de critérios, como as necessidades, os comportamentos e as motivações de compra. Um segmento é um possível mercado-alvo para uma organização.

Essa etapa é o início do ciclo de criação de uma marca, visto que, primeiro, a empresa descobre necessidades e grupos diferentes no mercado e somente então estabelece a 
correspondência entre a competência organizacional e as oportunidades promissoras dos segmentos, define como alvo as necessidades e os grupos que é capaz de atender de forma superior e, por fim, posiciona seu produto e sua imagem de modo que o mercado-alvo os diferencie (CRAVENS; PIERCY, 2007; KOTLER; KELLER, 2006)

A segmentação é a base de desempenho superior da marca, pois, reconhecer, antes dos concorrentes, os segmentos de mercado e como eles se modificam, permite a empresa definir o seu mercado de atuação e estabelecer uma correspondência melhor entre suas marcas - por meio de mensagens e transmissão de significados, as competências que as diferenciam das demais e as exigências de valor dos compradores, a fim de melhor satisfazer os seus consumidores (CRAVENS; PIERCY, 2007; ELLWOOD, 2004; FURRIER, 2008b; LAMBIN, 2000).

A oportunidade de segmentação surge quando a marca não tem como se distinguir da concorrência em um mercado amplo e há diferenças nas respostas dos consumidores em relação a ela, o que permite que o mercado seja dividido em segmentos, cada um deles com uma demanda específica, a qual pode ser indicada pela quantidade e pela frequência de compra, lealdade à marca, o modo como a marca é consumida, o significado que a marca tem para o contexto dos consumidores etc. (CRAVENS; PIERCY, 2007; FURRIER, 2008b).

O grau de segmentação que a empresa utiliza varia num continuum entre o mercado considerado como um único grupo onde todas as pessoas têm as mesmas preferências e interesses - formando uma massa de consumidores - e o mercado individualizado, no qual cada pessoa é um segmento. No primeiro pólo está a estratégia de contra-segmentação, utilizada pelas marcas genéricas, a qual visa propor produtos sem variações, padronizados, fabricados em escala, que oferecem estritamente a função de base e são vendidos a um preço baixo e, desse modo, apóia-se na relação custo-benefício (KOTLER; KELLER, 2006; LAMBIN, 2000).

Já no extremo que considera cada consumidor como um segmento único, está a estratégia de hiper-segmentação, que, segundo Lambin (2000, p. 270), “conduz ao desenvolvimento dos produtos sob medida (personalizados), propondo, a um preço elevado, diversas opções ou funções secundárias variadas, para além da função de base”. Essa é a base do “marketing um a um” ou "marketing customizado", possibilitada pelo desenvolvimento tecnológico, que permite, por meio do uso de sistemas de gestão de relacionamento com o cliente, conhecer as necessidades, interesses e comportamentos dos consumidores e a realizar a personalização em massa (CRAVENS; PIERCY, 2007; KOTLER; KELLER, 2006). Essa é uma estratégia utilizada por marcas de fabricante, principalmente marcas de luxo, as quais possuem consumidores que prezam por produtos que, entre outras características, sejam exclusivos. 
Contudo, não se deve confundir as noções de segmentação e de diferenciação, sendo que esta última refere-se às diferenças dos produtos, em qualquer de suas características físicas e não-físicas, entre os concorrentes e entre os produtos de um mesmo fabricante propostos para segmentos diferentes, na tentativa de ganhar vantagem competitiva (CRAVENS; PIERCY, 2007; LAMBIN, 2000). Os produtos, de acordo com Lambin (2000, p. 246), são “diferenciados se os compradores pensam que eles são diferentes, isto é, que facultam soluções diferentes aos seus problemas”. Já a segmentação relaciona-se com as diferenças entre as necessidades dos consumidores que compõem o mercado, ao promover a desagregação do mercado como um todo para realizar a agregação de consumidores com interesses e características semelhantes (LAMBIN, 2000). Ou seja, resume Lambin (2000, p. 247), “a diferenciação é um conceito que descreve a diversidade da oferta, enquanto que a segmentação descreve a diversidade da procura”.

A marca promove a ligação entre esses dois conceitos, pois ela permite diferenciar produtos e serviços por meio de uma carga de significados que são consumidos por grupos de pessoas que desejam exprimir a sua diferença, originalidade e personalidade por meio das escolhas que efetuam e, desse modo, o ideal é que cada novo segmento seja atendido por uma nova marca pensada para atendê-lo melhor que a concorrência (KAPFERER, 2004a; LAMBIN, 2000).

Para tomar a decisão de segmentar ou não um mercado e, caso dividido, em quais grupos atuar, é de fundamental importância que a empresa analise o seu microambiente competitivo, composto pela própria corporação (a disponibilidade de recursos e competências e a cultura interna), pelos distribuidores (o grau de profissionalismo, concentração e o poder de barganha de cada distribuidor), consumidores (a disponibilidade de tempo ou dinheiro, o controle sobre a marca e a adequação ao processo de compra da marca) e concorrentes (a definição do cenário competitivo, a diferenciação entre os demais concorrentes, a avaliação da força estratégica das marcas concorrentes). Também, é necessária uma análise do macroambiente no qual a empresa está inserida, formado por fatores econômicos, demográficos, culturais, tecnológicos e, principalmente, políticos e legais.

De acordo com Cravens e Piercy (2007, p. 100),

o exame de segmentos específicos de mercado ajuda a identificar como (1) chegar a uma equivalência mais exata entre as preferências de valor dos compradores e as competências da organização e (2) comparar os pontos fortes (e fracos) da organização aos dos principais concorrentes de cada segmento. 
Para ser interessante segmentar um mercado, os agrupamentos de consumidores têm de apresentar respostas, em relação à marca, heterogêneas entre si e homogêneas internamente; os grupos devem ser identificáveis, acionáveis e estáveis durante o tempo necessário para que a estratégia de marca pretendida consiga produzir resultados favoráveis e, desse modo, torne a relação custo-benefício da segmentação financeiramente atraente (CRAVENS; PIERCY, 2007).

Caso a empresa se decida por segmentar o mercado, a questão torna-se determinar o(s) critério(s) para promover essa divisão. Os candidatos são vários: produto, preço, qualidade, condições de uso, benefício esperado, demografia, geografia, estilo de vida, personalidade dos consumidores, necessidades, atitudes, preferências, comportamento de compra e outros (CRAVENS; PIERCY, 2007; KAPFERER, 2004a; KOTLER; KELLER, 2006).

Contudo, algumas variáveis, como estilo de vida e demografia, são mais úteis para descrever segmentos após a sua formação do que para identificá-los (CRAVENS; PIERCY, 2007). E, normalmente, realiza-se a segmentação com base em mais de um fator, o que demonstra ser mais vantajoso, pois permite criar segmentos que possuem melhor correspondência com a proposta do produto/marca oferecida pela empresa e, consequentemente, acabam percebendo um maior valor recebido.

Escolhidas as variáveis de segmentação, os agrupamentos, segundo Cravens e Piercy (2007, p. 111), são formados

\begin{abstract}
por meio do: (a) agrupamento de clientes, obtendo características descritivas e, em seguida, diferenças de resposta entre os grupos ou (b) formação de grupos com base na resposta [...], determinando se os grupos podem ser identificados com base nas diferenças entre suas características.
\end{abstract}

A partição do mercado total, de acordo com Lambin (2000, p. 235) “opera-se geralmente em duas etapas: uma etapa, dita macro-segmentação, que identifica os produtosmercado e uma etapa de micro-segmentação, que conduz à identificação dos segmentos no interior de cada um dos produtos-mercado definidos”. Na primeira etapa, os produtos-mercado são formados por meio da combinação de grupos de consumidores - e seus desejos e necessidades - com a função base de um produto, considerando-se as possibilidades de substituição entre diferentes produtos e marcas, a extensão para outras funções, a substituição de tecnologias e as diversas maneiras pelas quais as pessoas fazem escolhas para atender as suas exigências (CRAVENS; PIERCY, 2007; LAMBIN, 2000).

A micro-segmentação consiste em repartir o produto-mercado definido na etapa anterior em segmentos de consumidores estreitamente caracterizados por uma ou mais variáveis, os quais 
buscam numa marca/produto o mesmo conjunto de atributos e benefícios e, desse modo, recebem um mix de marketing projetado para atender às exigências de valor do segmento (CRAVENS; PIERCY, 2007; LAMBIN, 2000). Assim, Lambin (2000, p. 246) afirma que "o objetivo da micro-segmentação é analisar a diversidade das necessidades dos diferentes grupos de compradores no interior dos produtos-mercado identificados pela análise de macro-segmentação”.

Após dividir o mercado total, cada segmento-alvo precisa ser estudado para determinação de sua atratividade potencial, devendo-se analisar os clientes, os concorrentes, a atratividade financeira e mercadológica dos agrupamentos e a equivalência deles com as competências/habilidades da empresa para implementar a estratégia e o posicionamento de marca, que serão as próximas etapas da construção da marca (CRAVENS; PIERCY, 2007)

Compreender a segmentação e a estratégia de segmentação, segundo Aaker e Joachimsthaler (2007, p. 156), é

\footnotetext{
importante porque a estrutura do portfólio da marca [próxima etapa do ciclo de construção da marca] precisa revestir a estratégia de segmentação. [...] Para criar uma estrutura de portfólio, é necessário, portanto, identificar as variáveis de segmentação, os segmentos mais importantes, as necessidades não satisfeitas desses segmentos e como a marca se conectará com eles.
}

A segmentação estabelece a base das estratégias de identificação e posicionamento da marca no mercado-alvo, auxiliando a detectar grupos de compradores que responderão favoravelmente aos seus esforços. O próximo passo é desenvolver a arquitetura da marca, tomando-se decisões importantes sobre como será criada a nova marca e o seu relacionamento com as marcas já existentes na empresa.

\subsubsection{Arquitetura de marca}

Após a decisão de segmentar ou não o mercado e - caso a divisão tenha sido realizada - feita a escolha dos agrupamentos de consumidores, a empresa deve decidir sobre a criação ou não de uma marca (sendo que essa segunda alternativa pode levar à criação de uma marca genérica). Se feita a opção por criar uma marca, deve-se escolher se a marca utilizada será do fabricante ou de algum parceiro, como um distribuidor ou varejista, e qual será o seu papel no portfólio de marcas da empresa, ou seja, como será a arquitetura da marca (KOTLER, 2000).

Ao fazer essas três escolhas, é necessário ter em mente que as marcas necessitam que algumas condições sejam satisfeitas, como: demanda atraente para justificar os investimentos 
que ela necessita; a qualidade percebida do produto que receberá a marca deve ser a melhor possível ao preço de mercado; a distribuição do produto deve ser adequada para que este esteja sempre disponível e a exposição no ponto-de-venda deve ser feita de forma que valorize a marca por meio de alta visibilidade a ela (PEREZ, 2004).

A arquitetura de marca é uma estrutura organizadora do portfólio de marcas, o qual, segundo Kapferer (2004a, 126), “é uma resposta a objetivos específicos da empresa, como dominação da categoria, criação de barreira na entrega do circuito de distribuição, atração e fidelização dos consumidores”. Ela especifica os papéis das marcas, as relações entre si e os diferentes contextos de marca no que diz respeito aos produtos e seus respectivos mercados, a fim de: criar marcas eficazes e poderosas; distribuir recursos para o desenvolvimento da marca; criar sinergia; alcançar clareza nas ofertas dos produtos; aumentar o valor da marca; e dar uma plataforma para opções futuras de crescimento (AAKER; JOACHIMSTHALER, 2007).

Na definição da arquitetura de marca, uma empresa pode utilizar cinco diferentes estratégias para atribuir marcas - e seus papéis - para seus produtos e serviços. A primeira, conhecida como estratégia de casa com marca, consiste em uma marca única, dominante, para todos os produtos ou serviços da empresa (AAKER; JOACHIMSTHALER, 2007). Esta opção cria as marcas guarda-chuva, ou marcas mestras, as quais são nomes fortes úteis para proteger novos lançamentos.

A marca guarda-chuva, de acordo com Aaker e Joachimsthaler (2007, p. 120), “pode agregar valor adicionando associações que contribuam para uma proposta de valor, fornecendo credibilidade à oferta, compartilhando a visibilidade da marca-mestra e gerando eficiência na comunicação que possa resultar em vantagens de custo”.

Essa estratégia é mais bem empregada quando a empresa que a utiliza possui produtos com qualidade e preços similares e sinergia entre eles, pois uma única marca transmitida em todos os produtos e ao longo do tempo é muito mais fácil de ser compreendida e lembrada do que uma dezena de marcas individuais, cada uma com suas próprias associações (AAKER; JOACHIMSTHALER, 2007; PRADO; FARINHA, 2008).

Essa opção estratégica possui como vantagens a menor necessidade de investimentos e maior consistência na comunicação da marca; fortalece a clareza, a sinergia e a promoção da marca; os custos e a credibilidade exigida para lançar novos produtos - principalmente inovações - são menores e a probabilidade de aceitação deles por parte dos consumidores é maior, devido às associações anteriores positivas em relação à marca-chuva; e a maior visibilidade da marca no ponto de venda, por causa da sua presença em diversos produtos/serviços (AAKER; JOACHIMSTHALER, 2007). 
No entanto, o uso de marcas guarda-chuva apresenta riscos, como a possibilidade de transferência de associações negativas entre diferentes produtos da mesma empresa, mas que estão sob a mesma marca; e a diluição do posicionamento da marca quando os consumidores deixarem de associá-la a um produto específico, devido à ampliação para uma grande variedade de produtos/serviços (AAKER; JOACHIMSTHALER, 2007; PRADO; FARINHA, 2008).

Marcas individuais exclusivas para cada item de produto é a segunda opção estratégica, também chamada de casa de marcas. Ela é utilizada para dar "vida própria” e independente à marca, atribuindo-lhe uma identidade específica e singular que permite o posicionamento claro e direto na mente do consumidor de um segmento-alvo e, desse modo, o oferecimento de uma proposta de valor melhor direcionada (AAKER; JOACHIMSTHALER, 2007).

Porém, alcançar consumidores de segmentos-alvo não é a única razão para utilizar essa estratégia, sendo que, entre outros motivos, tem-se: evitar associação de marca que seria incompatível com uma oferta; possuir uma nova associação de classe de produtos usando um nome poderoso que reflita um benefício importante; e evitar ou minimizar o conflito de canais (AAKER; JOACHIMSTHALER, 2007).

De acordo com Souza e Nemer (apud PRADO; FARINHA, 2008, p. 53), alguns fatores favorecem o conceito de marcas múltiplas, como:

a ausência de um histórico de investimentos em imagem institucional; a experiência anterior da empresa na introdução de marcas individuais; grande variedade de categorias de produto, produtos e/ou versões muito específicos; as crenças na competição interna como fator motivador e propiciador de eficácia e no posicionamento preciso como fator crítico de sucesso.

Também, quanto mais elevado o grau de envolvimento do consumidor, mais adequado é o uso de marcas múltiplas, pois as pessoas gostam de comprar marcas que reflitam mais intimamente o conceito que fazem de si mesmas; assim, se o produto/serviço consumido é importante para o desenvolvimento das auto-imagens, mais importante é para a empresa criar uma marca independente que possua os significados buscados por esses consumidores (ELLWOOD, 2004; KAPFERER, 2004a). E, de acordo com Ellwood (2004, p. 45), a estratégia de casa de marcas “é conveniente para empresas que desenvolvem produtos inovadores e criam novas categorias, uma vez que podem posicionar o novo produto ou categoria sem referência a outras proposições de marca”.

Entre os benefícios da estratégia de marcas múltiplas, tem-se a possibilidade de criar identidades de marcas diferentes e mais sintonizadas com os públicos específicos, as marcas 
múltiplas podem dar impressão de novidade ao consumidor e garantir maior espaço na gôndola para a empresa, os riscos de transferência de associações negativas entre produtos da mesma empresa, mas com marcas diferentes, é menor (ELLWOOD, 2004).

Porém, com essa estratégia, o custo de lançamento de novos produtos é muito maior do que quando se usa uma marca guarda-chuva; existem poucos benefícios cruzados para o resto da carteira e, assim, o sucesso em uma marca não é facilmente transferível a outra; e há maior gasto para construção da marca, pois os investimentos são somente para um produto, diferentemente das outras estratégias, em que eles são diluídos entre mais de um item (ELLWOOD, 2004).

Outra estratégia de atribuição de marca é combinar o nome da empresa com o nome do produto ou serviço. Esta opção busca personalizar um produto sem abandonar o aval de uma marca guarda-chuva, criando-se submarcas que aumentam ou modificam as associações da marca mestra (AAKER; JOACHIMSTHALER, 2007). Normalmente, a marca guarda-chuva, que possui um papel de endossante e impulsionadora da submarca, representa, conforme Aaker e Joachimsthaler (2007, p. 106), “as organizações e não os produtos, porque os fatores associados a organizações, como inovação, liderança e confiança, são particularmente relevantes no contexto do endosso”. Se a submarca for tão importante quanto a marca guardachuva, ocorre uma situação de co-impulso (AAKER; JOACHIMSTHALER, 2007).

Sendo uma estratégia híbrida em relação à opção de marcas múltiplas e de marca guarda-chuva, a marca que combina o nome da empresa com o do produto/serviço acaba por amenizar tanto as vantagens quanto as desvantagens de cada uma das duas estratégias. Contudo, Prado e Farinha (2008, p. 65) destacam uma desvantagem da estratégia mista que ocorre "no caso de o produto não ter uma boa aceitação no mercado, podendo prejudicar a imagem da organização”.

A quarta forma de atribuir marca é criar uma marca exclusiva para cada linha de produtos ou serviços, ou seja, uma marca de série, diferente da marca da empresa. É uma estratégia de extensão de uma marca forte, transformando-a em marca guarda-chuva. Independente dos possíveis perigos, o uso da estratégia de marcas de série está aumentando à medida que as empresas tentam fazer vendas cruzadas aos clientes leais, pois ela permite que o sucesso e a familiaridade de uma marca sejam transferidos para os novos produtos dentro da mesma categoria ou em relacionadas, sendo que o mesmo objetivo não seria atingido com uma marca única para todas as ofertas da empresa ou com uma marca que combinasse o nome da empresa com o do novo produto (CRAVENS; PIERCY, 2007; ELLWOOD, 2004).

Esse apoio de credibilidade fornecido pela marca de linha torna mais fácil e barato para uma empresa lançar novos produtos na série ou em categorias relacionadas devido à 
redução da resistência de toda a cadeia de distribuição e do consumidor, pois a história e o posicionamento da marca já estão contados e claros (ELLWOOD, 2004).

Adições bem sucedidas nas marcas de série podem modificar as percepções delas, ajudando-as a se revitalizarem e/ou a se encaixarem em outro lugar, mas, acreditar que por meio do uso dessa estratégia é possível criar volume complementar em um mercado competitivo sem investir é um erro, dado que os princípios que guiam o sucesso de novos produtos não deixam de ser válidos nesse caso (AAKER; JOACHIMSTHALER, 2007; KAPFERER, 2004a). Também, é importante observar os movimentos verticais que uma extensão da marca de linha pode provocar, pois, enquanto é fácil para a marca mover-se de uma posição de alta qualidade e/ou preço para uma mais baixa, desfazer esse movimento por meio da remoção da novidade pode ser bem difícil (ELLWOOD, 2004).

Entre as vantagens dessa estratégia, têm-se menores custos e riscos de lançamento de novos produtos/serviços, principalmente quando eles transmitem uma nova tendência de estilo de vida no mercado; compartilhamento dos custos fixos entre os itens da linha; mais oportunidades para o cliente experimentar e usar a marca; maior poder de barganha para a marca; fortalecimento da imagem da marca e menor necessidade de material de apoio à marca no ponto de venda, em decorrência da criação de um grande e visível bloco comercial nas estantes, onde as marcas individuais de produto estariam perdidas entre a concorrência; e alavancagem dos ativos da marca e sinergia ao gerar exposições e associações de marca em contextos diferentes (AAKER; JOACHIMSTHALER, 2007; CRAVENS; PIERCY, 2007; ELLWOOD, 2004).

Contudo, algumas desvantagens podem ser elencadas para as marcas de linha, como a redução do valor da marca como um todo, decorrente de mudanças negativas na percepção dos consumidores, se algum produto/serviço da série tiver qualidade inferior; a diluição da identidade e do poder distintivo da marca devido ao excessivo aumento da linha, principalmente se a expansão ocorrer para categorias inconsistentes com as quais a marca foi originalmente criada; e maior dificuldade para movimentar a marca para um nível mais elevado de preço e/ou qualidade (AAKER; JOACHIMSTHALER, 2007; CRAVENS; PIERCY, 2007; ELLWOOD, 2004).

A quinta estratégia para se atribuir uma marca é o uso de uma formada por 2 ou mais marcas fortes. Esta é uma estratégia de co-paternidade (conhecida também como co-marcas ou co-branding) onde duas ou mais marcas, da mesma empresa ou não, reconhecidas como especialistas nos próprios campos de atuação, se associam em benefício da nova marca que se pretende criar (AAKER; JOACHIMSTHALER, 2007; CRAVENS; PIERCY, 2007; ELLWOOD, 2004; KAPFERER, 2004a). 
Há a possibilidade, também, de uma das co-marcas ser uma marca de componente ou ingrediente ou de ocorrer o endosso organizacional de marca para impulsionar a marca independente, por meio da transferência de credibilidade à oferta (AAKER; JOACHIMSTHALER, 2007). Este último caso difere-se da marca formada pelo nome da empresa combinado com o nome do produto ou serviço, pois, no caso das marcas endossadas, a empresa não anexa o seu nome ao nome da marca, apenas endossa (“patrocina”) a nova marca.

Essa opção estratégica possibilita, de acordo com Aaker e Joachimsthaler (2007, p. 140), “a oferta capturar duas (ou mais) fontes de brand equity e, com isso, aumentar a proposta de valor e o ponto de diferenciação”. O co-branding tem crescido consideravelmente, visto que aproveitar a complementaridade de cada marca é uma alternativa que contorna os problemas de falta de legitimidade de cada uma delas tomada isoladamente; porém, é importante que as marcas participantes da parceria possuam associações fortes e complementares (AAKER; JOACHIMSTHALER, 2007; KAPFERER, 2004a).

Ademais, por meio da estratégia de co-paternidade, há a possibilidade de a empresa desenvolver o marketing de causas, o qual é uma forma de marketing societal que tem ganhado força no século XXI e é definido como um relacionamento ou uma parceria de longo prazo da marca com uma causa, ou certo número de causas, visando ao benefício mútuo (KOTLER; KELLER, 2006; LAFFERTY; GOLDSMITH, 2005).

As empresas vêem essa aliança entre marca e causa(s) como uma oportunidade para criar uma ligação mais profunda com o consumidor que irá resultar em melhora da reputação e da consciência de marca, menores chances de ataques a integridade ou operações da empresa advindas de grupos de pressão, aumento da fidelidade do cliente à marca e mais exposição na mídia (KOTLER; KELLER, 2006; LAFFERTY; GOLDSMITH, 2005; LEITCH; DAVENPORT, 2007). Além disso, a terceira geração das marcas acredita que os clientes tenderão a procurar, cada vez mais, sinais de boa cidadania corporativa que vão além do fornecimento de benefícios racionais e emocionais (KOTLER; KELLER, 2006).

Há três formas, conforme Hoeffler e Keller (2002), para aliar a marca a uma causa: 1) criar uma causa totalmente nova (self branding); 2) associar-se diretamente com uma organização relacionada a uma causa e co-nomeá-la, geralmente na forma de patrocinador; e 3) associar-se a uma organização já existente e relacionada a uma causa, mas desenvolver um programa explicitamente nomeado pela marca (joint branding).

Um modelo para avaliar sistematicamente as opções de causa para aliar a marca envolve a identificação dos programas voluntários convergentes com os interesses da empresa e com os valores que ela deseja associar à sua marca e o estudo das seguintes questões: 1) 
requisitos, 2) benefícios, 3) responsabilidade por atividades sócio-ambientais de uma empresa específica; e 4) investimentos necessários para participar do programa (DARNALL, 2008).

Entretanto, um estudo de Hoeffler e Keller (2002) constatou que a escolha da causa para se aliar gira em torno do interesse da empresa em reforçar a imagem e o patrimônio da marca existentes ou ampliar e adicionar associações a esse patrimônio e imagem de marca e, desse modo, essa é uma decisão estratégica extremamente importante para a marca, pois

associar-se com causas que têm um alto grau de afinidade com a marca [, estratégia de comunalidade,] irá fortalecer o conhecimento existente da marca. [...] Associar-se com causas com baixo grau de afinidade [, estratégia de complementaridade,] (a) pode aumentar a diferenciação e complementaridade mais do que se associando com uma causa com alto grau de afinidade e (b) será mais difícil do que associar-se com causas com um alto grau de afinidade (HOEFFLER; KELLER, 2002, p. 83-84).

Já, no que tange ao conhecimento da causa, Lafferty e Goldsmith (2005) observaram que qualquer que seja a causa, a marca beneficia-se do efeito positivo que é gerado pelo comportamento benevolente, o que sugere que os gerentes de marca não precisam ficar limitados apenas a causas famosas, mas devem, sim, avaliar as atitudes prévias em relação à causa para assegurar que elas são positivas.

Contudo, Hoeffler e Keller (2002), rebatem a irrelevância do conhecimento da causa ao elencá-lo entre os três fatores que são particularmente importantes em predizer a extensão da alavancagem da marca que pode resultar da sua associação com causas, os quais são: 1) consciência e conhecimento da causa (se os consumidores não conhecem a causa ou não têm familiaridade com ela, então não há nada que possa ser transferido dela para a marca); 2) relevância e sentido do conhecimento da causa (importância e relevância para a marca das associações, julgamentos e sentimentos positivos que a causa possui); e 3) transferência do conhecimento da causa (qual a capacidade de se transferir as associações, julgamentos e sentimentos úteis e significativos da causa para a marca).

Sobre a relevância da causa para os consumidores, Hoeffler e Keller (2002) comentam que as causas que têm um alto impacto pessoal percebido pelos consumidores-alvos da marca produzem melhores resultados para a marca em uma possível aliança. E, sobre a transferência do conhecimento da causa quanto maior a variedade de conexões entre a marca e a organização sem fins lucrativos o consumidor perceber, maiores serão as oportunidades para transferir as associações da entidade sem fins lucrativos para a marca (HOEFFLER; KELLER, 2002). 
Entretanto, Bronn e Vrioni (2001) lembram que somente uma contribuição consistente e crível a uma causa (ou uma organização sem fins lucrativos) pode construir imagem e patrimônio de marca social.

Entre as vantagens da estratégia de co-marcas têm-se a possibilidade de dividir, entre as marcas, os custos e riscos do desenvolvimento e lançamento da nova oferta; a flexibilidade para adaptar-se às mudanças do mercado sem alterar permanentemente as marcas envolvidas; a alavancagem das bases de clientes das marcas envolvidas; e a capacidade de agregar para a co-marca, associações que seriam difíceis de serem obtidas se os produtos atuassem isoladamente (CRAVENS; PIERCY, 2007; LEITCH; DAVENPORT, 2007).

Porém, há desvantagens dessa forma de atribuição de marca, como a criação de associações negativas para a nova marca, decorrente da incompatibilidade entre as parceiras ou pela diferença na percepção de qualidade e prestígio entre elas; o aumento da complexidade na gestão da co-marca, por causa da necessidade de conciliar os interesses dos parceiros; e o risco de um dos parceiros achar que o lucro advindo é inadequado ou que a parceria não se encaixa mais estrategicamente em seu negócio e, desse modo, se retirar ou ficar no negócio, mas sem o interesse e a colaboração necessários (AAKER; JOACHIMSTHALER, 2007; LEITCH; DAVENPORT, 2007).

Decidida a criação de marca e a estratégia de atribuí-la à sua oferta, a empresa deve agora iniciar o processo fundamental para a criação do conceito que será visto no mercado, o qual é a definição da identidade da marca, que consiste em definir aspectos que impactarão no posicionamento da marca e na forma como ela será comunicada ao mercado e recebida por ele.

\subsubsection{Identidade da marca}

Identidade da marca é o modo como a empresa busca representá-la ou significá-la, abrangendo um conjunto de associações e valores ideais que o estrategista de marca procura criar ou manter - o que implica na criação de promessas para os consumidores (AAKER; JOACHIMSTHALER, 2007; KHAUAJA, 2008; KOTLER; KELLER, 2006). Com o tempo, ela agrega, também, a soma das experiências vividas pela marca em todos os pontos de contato com o cliente (KAPFERER, 2004b).

Cada marca ativamente gerenciada necessita de uma identidade - uma visão dos seus significados, pois ela é o que inspira o programa de construção de marca (AAKER; JOACHIMSTHALER, 2007). Assim, a identidade de uma marca precisa ser clara e única, 
pois, se for confusa ou ambígua, há pouca chance de que ocorra uma construção adequada dessa marca (AAKER; JOACHIMSTHALER, 2007; KHAUAJA, 2008).

Uma identidade eficaz precisa exercer três funções: estabelecer a personalidade da marca e a proposta de valor; comunicar essa personalidade de forma diferenciada e clara; transmitir poder emocional além da imagem mental (KOTLER; KELLER, 2006). Desse modo, a identidade de marca deve ajudar a estabelecer uma relação com o cliente que se pareça com uma relação pessoal e, para tanto, ela deve compreendê-lo e entregar-lhe os valores que são desejados, através de uma proposta de valor que envolva benefícios funcionais, emocionais e auto-expressivos (AAKER; JOACHIMSTHALER, 2007).

Mesmo sendo os benefícios não-tangíveis os que garantem maior poder e distinção para a marca, os benefícios funcionais jamais devem ser esquecidos da composição da sua identidade, pois, com frequência, o consumidor define a sua escolha com base em atributos bastante concretos, palpáveis e tangíveis, como escopo e características do produto, qualidade/valor, país de origem e design (AAKER; JOACHIMSTHALER, 2007; KAPFERER, 2004a).

Já os benefícios emocionais, como o prestígio, o altruísmo e o sentimento de pertencer a um grupo seleto, geram a aura de uma marca, capaz de fazer com que o comprador e o usuário dela sintam alguma coisa por intermédio da agregação de riqueza e profundidade ao processo de compra, à propriedade e à experiência de uso (AAKER; JOACHIMSTHALER, 2007). Sendo essa aura exclusiva, ela permite a marca se diferenciar dos concorrentes, que podem reproduzir os seus benefícios funcionais; mas deve ser cuidadosamente gerida a fim de se estender a sua relevância com o passar do tempo e reduzir os efeitos colaterais dos gostos cíclicos dos consumidores (ELLWOOD, 2004).

O benefício de auto-expressão, como personalidade e valores da marca, é importante para a identidade da marca, pois ele permite que a pessoa utilize a compra e o consumo da marca como um veículo para proclamar uma determinada auto-imagem, sendo que as pessoas alteram o auto-conceito que desejam transmitir dependendo da situação em que se encontram e conforme o tempo vai passando (AAKER; JOACHIMSTHALER, 2007).

Para construir a identidade da marca, é necessário incentivar o conhecimento da mesma entre os clientes potenciais, diferenciar a marca dos concorrentes e representar aquilo que a organização pode fazer e fará com o tempo (AAKER; JOACHIMSTHALER, 2007). As escolhas iniciais dos elementos ou identidades da marca (nome da marca, logos, símbolos, caracteres, representantes, slogans, jingles, embalagens e sinais, por exemplo) são impulsionadoras do valor da marca, pois a auxiliam a transmitir os seus benefícios, a 
diferenciar-se dos concorrentes e, desse modo, a ser lembrada frequentemente e facilmente em diversas circunstâncias (AAKER; JOACHIMSTHALER, 2007; KOTLER; KELLER, 2006).

Mais do que lembrar o nome da marca, no entanto, o conhecimento de marca inclui relacioná-la (nome, logomarca, símbolos, entre outros) a certas associações na memória. O consumidor necessita saber quais necessidades dele a marca foi criada para satisfazer (KELLER, 2002). Zyman (apud KHAUAJA, 2005) complementa afirmando que construir identidade de marca significa definir quem a marca é e para onde pretende ir e significa, também, desenvolver uma arquitetura de marca coerente, que relacione a marca corporativa, as marcas do produto e as submarcas.

Portanto, o desenvolvimento da identidade de marca depende da completa compreensão do seu público relevante, ou seja, não somente os consumidores, mas também fornecedores, distribuidores, parceiros estratégicos, funcionários, comunidades que interagem com a marca, a mídia e diversas instituições ligadas à marca e à empresa detentora dela (AAKER; JOACHIMSTHALER, 2007; KHAUAJA, 2005). Ademais, devem ser considerados os concorrentes, visto que as marcas precisam se diferenciar deles ao longo do tempo; e a própria organização, cujas práticas, cultura interna e disposição em investir, podem tanto auxiliar quanto depreciar a proposição de valor de uma marca (AAKER; JOACHIMSTHALER, 2007).

Entendido o que se é esperado da marca, deve-se definir os valores, competências e aspirações dela. Esse conjunto precisa estar alinhado com a direção estratégica da organização: os valores devem refletir a cultura da organização e ser reforçados por ela; as competências são a fonte para diferenciação e reconhecimento da marca no mercado e as aspirações para o futuro guiam o desenvolvimento de novos produtos e os planos de expansão da marca.

Com a identidade da marca desenvolvida, parte-se para a definição de como transmitila ativamente para o público de interesse da empresa, ou seja, inicia-se a etapa de posicionamento da marca, que é a base do programa de comunicação da marca (AAKER; JOACHIMSTHALER, 2007; LAMBIN, 2000).

\subsubsection{Posicionamento das marcas}

A identidade da marca é uma proposição de valor que tenta incluir todas as necessidades funcionais, sociais e psicológicas dos clientes; faz parte dela também o posicionamento da marca. Segundo Aaker (1996, p. 71), o posicionamento da marca é uma 
"proposição de valor que é ativamente comunicada para o público-alvo e que demonstra a vantagem da marca sobre as marcas concorrentes”.

De acordo com Kotler e Keller (2006, p.305),

posicionamento é a ação de projetar a marca para ocupar um lugar diferenciado na mente do público-alvo. Um bom posicionamento de marca ajuda a orientar a estratégia de marketing, esclarecendo a essência da marca, que objetivos ela ajuda o consumidor a alcançar e como o faz de maneira inconfundível. O resultado do posicionamento é a criação bem-sucedida de uma proposta de valor focada no cliente, ou seja, um motivo convincente pelo qual o mercado-alvo deve comprar determinado produto.

Ampliando essa definição, Serralvo e Furrier (2005, p. 10) afirmam que o posicionamento de marca é "o processo de estudo, definição e implementação de uma oferta diferenciada de valor cujos atributos proporcionem uma posição vantajosa sustentável para uma marca em relação à concorrência em uma categoria, do ponto de vista da percepção de um público-alvo”. Portanto, o posicionamento, segundo Furrier (2008b, p. 171), “lembra que as escolhas dos clientes são feitas em uma base comparativa, e um produto só será escolhido se fizer parte claramente desse universo de seleção”.

Com uma hipotética origem nas discussões sobre segmentação de mercado, públicoalvo e estruturas de marketing, o posicionamento de marcas foi evoluindo com o passar do tempo, sendo, segundo Furrier (2008, p. 141), a seguinte progressão:

1) Sem marca: commodities, itens não industrializados ou indiferenciados.

2) Marca como referência: nome do produtor usado como identificação, fonte de atributos racionais e garantia de qualidade/consistência.

3) Marca como personalidade: marca isolada, suporte de marketing para criar apelo emocional, foco em benefícios do produto e propaganda.

4) Marca como ícone: consumidor se apossa da marca e incorpora a ela valores sociais, com a propaganda a sugerir relacionamentos de intimidade, uso de linguagem simbólica e expansão internacional.

5) Marca como companhia: a marca tem identidade complexa, a corporação se posiciona para diversos públicos, com estratégia de comunicação integrada.

6) Marca como política: companhia e marca alinhadas a questões sociais e políticas. Consumidores se relacionam com a marca, com a organização e com seu reflexo político [e social].

O posicionamento de marca engloba associações, estabelecidas na mente dos clientes, ou subconjunto delas, que derivam da identidade da marca e que, de acordo com Furrier 
(2008, p. 147), quando se tornam motivos de compra, "simplificam o processo de decisão, dão base para a formação de atitudes favoráveis e colaboram para futuras extensões de uma marca”. Assim, a empresa deve garantir que todos os itens que criam valor à marca sejam percebidos e associados pelos consumidores e que os que destroem valor não sejam relacionados à marca por eles.

Portanto, o gerenciamento de marca deve buscar implementar um posicionamento dela favorável, distinto, duradouro e relevante para o seu público-alvo, tornando essa posição a projeção desejada, pela empresa, da imagem da marca na mente dos consumidores e diferenciado-a da dos concorrentes (CRAVENS; PIERCY, 2007; FURRIER, 2008b). Essa necessidade do trabalho diferenciado com a marca, segundo Furrier (2008b, p. 164)

surge como decorrência de uma situação complexa: de um lado, é o consumidor quem decide o futuro de uma marca, quando se vê pronto a pagar mais caro ou a fazer um esforço extra para possuí-la; de outro, reafirma-se a necessidade da marca para o cliente como determinante de percepção/imagem nos processos de escolha comparada e compra.

A criação de um posicionamento adequado é importante, pois, segundo Kotler e Keller (2006, p.270), "para que as estratégias de branding sejam bem-sucedidas e o valor da marca seja criado, os consumidores devem estar convencidos de que existem diferenças significativas entre as marcas numa categoria de produto ou serviço”. Assim, esse processo possui uma dualidade, por que ao mesmo tempo em que posiciona a marca em uma categoria de produto ou serviço, ele deve diferenciá-la em relação aos concorrentes dessa classe (SERRALVO; FURRIER, 2005). Se ele falhar nessa última função, a marca poderá ser identificada em uma categoria, porém, devido à padronização de referenciais, mais semelhante aos concorrentes ela se parecerá (FURRIER, 2008b).

A seleção de um posicionamento que atenda adequadamente essa dualidade demanda uma compreensão das exigências de valores dos compradores - o que se pressupõe a necessidade da segmentação do mercado - e de suas percepções das marcas concorrentes, a fim de se decidir quais atributos e associações precisam ser trabalhados para oferecer a melhor proposta de valor da marca para cada mercado-alvo buscado pela organização (CRAVENS; PIERCY, 2007; FURRIER, 2008b).

Além disso, para escolher uma posição de marca vantajosa devem-se reunir, de acordo com Lambin (2000, p. 274-275), os seguintes requisitos:

1) ter um bom conhecimento do posicionamento atual detido pela marca no espírito dos compradores [...]; 2) conhecer o posicionamento detido pelas marcas 
concorrentes, em particular as marcas concorrentes prioritárias; 3) escolher um posicionamento e reter o argumento mais pertinente e mais credível para justificar o posicionamento adotado; 4) avaliar a rentabilidade potencial do posicionamento detido [...]; 5) verificar se a marca detém a personalidade requerida para conseguir atingir o posicionamento procurado no espírito dos compradores; 6) medir a vulnerabilidade do posicionamento adotado; 7) assegurar-se de que existe uma boa coerência entre o posicionamento escolhido e as outras variáveis do marketing: preço, distribuição, comunicação, embalagem, serviços etc.

Acrescenta-se a estes requisitos o fato de que o posicionamento de marca adotado deve estar plenamente alinhado com a sua identidade. A posição, tal qual a identidade, relaciona-se à idéia de como a marca deveria ser percebida pelo mercado, porém, o primeiro utiliza apenas um subconjunto do segundo componente da marca e, desse modo, não revela toda a riqueza de significados dela e nem reflete o seu potencial (FURRIER, 2008b). Assim, durante a construção de uma marca, é importante garantir que os dois processos estão alinhados e deve-se evitar uma armadilha muito comum nas empresas, que ocorre quando se define a identidade da marca com vistas no posicionamento dela, ou seja, o posicionamento da marca caba por influenciá-la e, desse modo, restringe-a.

Definido o posicionamento da marca, é interessante que a empresa reúna as decisões relativas a ele em uma declaração que, segundo Furrier (2008b, p. 186-187), deve conter “a descrição do cliente-alvo [...], a definição da associação a determinada categoria de produto, a razão por que a marca deve ser a escolhida, ou seja, o ponto diferencial, e como este se liga às metas do cliente-alvo”.

Feito isso, parte-se para a decisão da estratégia de posicionamento, que é diferente do seu conceito. O posicionamento de marca indica a percepção ou associação em relação a ela e deve estar ligado às preferências e necessidades dos compradores por meio de uma proposta de valor (CRAVENS; PIERCY, 2007). Portanto, o conceito é a primeira etapa para criar a estratégia de posicionamento, a qual é um conjunto coordenado das ações de marketing que possuem o objetivo de implementá-lo para atender às necessidades e exigências dos compradores pretendidos, a um custo que produza margens rentáveis para a organização (CRAVENS; PIERCY, 2007).

A estratégia de posicionamento é importante quando se adota um posicionamento diferente para cada segmento atingido pela marca, o que a obriga a justificar o porquê que ela deve ser considerada por esse grupo e o motivo de ser melhor do que as concorrentes (FURRIER, 2008b; LAMBIN, 2000). Embora não sejam necessárias mudanças frequentes, 
uma estratégia de posicionamento bem-sucedida deve ser avaliada regularmente para identificar as mudanças nas preferências do comprador e as variações nas estratégias do concorrente, a fim de se evitar a ineficácia e a perda de valor da posição possuída pela marca, que pode ocorrer devido aos seguintes erros citados por Cravens e Piercy (2007, p. 185):

- Subposicionamento - quando os clientes têm apenas vagas idéias sobre a companhia e seus produtos e não percebem nada distinto sobre eles;

- Superposicionamento - quando os clientes têm uma compreensão muito limitada da companhia, do produto ou da marca;

- Posicionamento confuso - quando alterações frequentes e mensagens contraditórias confundem os clientes em relação ao posicionamento da marca; e

- Posicionamento duvidoso - quando as alegações feitas para o produto ou marca não são encaradas pelo cliente como confiáveis.

Na execução do posicionamento da marca e da sua estratégia, a fim de transmitir a proposta de valor da marca e diferenciá-la dos concorrentes, a comunicação transforma-se em uma peça fundamental, pois a posição da marca é um estado cumulativo construído com base no histórico dela e sua visão futura (FURRIER, 2008b; SERRALVO; FURRIER, 2005). O processo de posicionar a marca ajuda a priorizar e focalizar a identidade da marca, apontando para qual fator há maior alavancagem em termos de posição em um determinado segmento e, em seguida, determinando-se os objetivos de comunicação (AAKER; JOACHIMSTHALER, 2007; FURRIER, 2008b). Assim, para a correta construção de uma marca, o próximo estágio caracteriza no processo de comunicação da sua proposta de valor, ou seja, do seu diferencial, dos seus valores e significados e, em última instância, da sua identidade, para o seu público de interesse.

\subsubsection{Comunicação da marca}

Feita a construção da identidade da marca, o próximo passo é transmiti-la, dando significado para ela. A comunicação da marca é a principal ferramenta para realizar a sua identidade e, desse modo, reforçar o vínculo emocional que a liga aos clientes (AAKER; JOACHIMSTHALER, 2007; KAPFERER, 2004a).

O maior veículo de comunicação da marca com o consumidor é o produto ou serviço adquirido, pois é o relacionamento com ele é que confirmará ou não todos os conceitos que o consumidor tinha em relação à marca; assim, o desempenho do produto ou serviço é muito importante e este pode ser traduzido na qualidade percebida da oferta. 
Essa qualidade deve no mínimo atender as expectativas dos clientes e, caso a empresa deseje que este se torne fiel à marca, a qualidade percebida deve então superar o que o cliente esperava da marca. Assim, muitos itens que influenciam a qualidade percebida da marca devem ser cuidadosamente pensados, como os serviços agregados, o estilo e design, o preço e a durabilidade do produto.

Além do produto ou serviço, os demais itens do composto promocional e de marketing, aliados à imagem corporativa, colaboram para viabilizar as associações recorrentes e diferenciadas que darão significado para a marca através da sua imagem (FURRIER, 2008b). A imagem da marca, segundo Keller (2002), diz respeito às características extrínsecas do produto ou serviço que buscam satisfazer as necessidades psicológicas e sociais do consumidor, ou seja, é o modo como o público vê a marca. Assim, a imagem refere-se mais a aspectos intangíveis da marca.

A imagem de marca, de acordo com Kotler e Keller (2006, p. 280), “diz respeito às percepções e crenças dos consumidores, as quais dependem, por sua vez, das associações retidas em sua memória [...] e que lhes transmitam significado, como o nome da empresa, de uma causa social, de uma personalidade, um país etc.”. Ampliando essas duas definições, Lambin (2000) observa que além das representações mentais, cognitivas e afetivas criadas pelos consumidores em relação à marca, a sua imagem engloba, também, o estoque de satisfações que criou, ou seja, o relacionamento dela com os consumidores.

Conforme Khauaja (2005), se a empresa for eficaz na construção de sua marca, a percepção dos consumidores, isto é, a imagem da marca, será equivalente à identidade da marca, que representa aquilo que a empresa deseja que sua marca signifique. Porém, não basta uma comunicação eficaz - clara e diferenciada - do posicionamento e identidade da marca, a organização precisa estar disposta a apoiá-la com um investimento substancial (AAKER; JOACHIMSTHALER, 2007).

Faz-se necessário destacar que em todo este processo deve haver a coerência na construção da marca. O posicionamento da marca deve ser a base de orientação de toda forma de contato do público com a marca, ou seja, de todo o seu mix de marketing (preço, promoção, ponto-de-venda e produto), e de todo contato da empresa com o público da marca.

Por fim, estando em um ambiente em que os gestores são pressionados a gerar valor para os seus acionistas, o retorno dos recursos investidos devem ser mensurados, avaliando-se se os esforços de promoção da marca ajudaram a construir um intervalo entre o custo do produto/serviço e o seu valor percebido e se reforçaram o vínculo emocional e psicológico entre a marca e os consumidores e, dessa forma, aumentaram a inelasticidade da demanda em 
relação à marca (FURRIER, 2008b; KAPFERER, 2004a). Portanto, o próximo passo, que é, também, o final, de um ciclo de construção da marca é a mensuração dos seus resultados.

\subsubsection{Mensuração dos resultados}

Seguindo a estrutura de criação de marcas, a etapa final do processo é mensurar se os resultados esperados para a marca foram atingidos, a fim de se analisar as decisões tomadas nas etapas anteriores e, se necessário, para modificá-las nos ciclos subsequentes de construção - ou, nesse caso, aprimoramento - da marca. Sem essa medição, os orçamentos de marca se tornam arbitrários e não é possível avaliar a sua contribuição à geração de valor para os acionistas (AAKER; JOACHIMSTHALER, 2007). Determinar como o público-alvo responderá a uma marca proposta e, após a sua comercialização, analisar as respostas dele é essencial para a correta gestão da marca, sendo que esse procedimento precisa ser realizado em bases constantes (CRAVENS; PIERCY, 2007).

Contudo, visto que a marca é um ativo intangível de difícil avaliação financeira, depender apenas de indicadores financeiros é uma receita para a subavaliação dos resultados atingidos e, desse modo, da erosão do real valor da marca e dos argumentos favoráveis para ao seu desenvolvimento. Para uma avaliação adequada do investimento nas marcas, Aaker e Joachimsthaler (2007) sugerem a utilização de indicadores que reflitam todas as dimensões do valor da marca: a consciência de marca, a qualidade percebida, a fidelidade dos clientes e associações (qualquer coisa que vincule o cliente à marca, como imagens, símbolos, atributos do produto e situações de uso).

Em acordo com esses indicadores, mas utilizando uma visão mais abrangente, Keller (2002) recomenda que se deve verificar as respostas em relação às marcas, por meio dos julgamentos e dos sentimentos dos clientes em relação a elas. Os julgamentos são as opiniões pessoais dos clientes e suas avaliações da marca e envolvem como os consumidores colocam junto todas as diferentes associações de desempenho e imagem da marca para formar diferentes tipos de opinião. Em termos de criação de uma marca forte, quatro tipos de julgamentos são importantes: qualidade percebida, credibilidade, consideração como uma opção de compra e superioridade (KELLER, 2002).

Já os sentimentos são as respostas emocionais e reações motivadas pela marca, como as emoções provocadas pela marca e por seu programa de marketing, a forma pela qual a marca afeta as percepções que os clientes têm de si mesmos e de seu relacionamento com outras pessoas (KELLER, 2002). 
Dado que o poder da marca deriva do que está residido nas mentes dos consumidores, o desafio das empresas em construir uma marca forte é, conforme Hoeffler e Keller (2002, p. 79), "garantir que os consumidores tenham o tipo correto de experiências com os produtos e serviços e seus programas de marketing, fazendo com que os pensamentos, sentimentos, imagens, crenças, percepções, opiniões desejados sejam associados à marca”.

Também, Keller (2002) aconselha medir a ressonância da marca, a qual foca no relacionamento e no nível de identificação que o consumidor tem com a marca e, desta forma, refere-se à natureza do relacionamento dos clientes com a marca e da extensão de sua "sintonia” com ela. A ressonância é caracterizada em termos de intensidade ou profundidade da ligação psicológica que o consumidor tem com a marca e, também, do nível de atividade gerado por esta lealdade.

A ressonância pode ser dividida em quatro categorias: lealdade (referindo-se à repetição de compra e participação no volume da categoria), vínculo pessoal, senso de comunidade e engajamento ativo (caracterizado pelos clientes dispostos a investir tempo, dinheiro, energia e outros recursos na marca, além de adquirí-la, como a criação de sites na Internet para a discussão de assuntos relacionados à marca) (KELLER, 2002).

O gestor de marcas, segundo Furrier (2008, p. 154), “procura garantir que a mensagem da marca tenha ressonância e se traduza para o público-alvo em ações de preferência e resultados financeiros, que são os efeitos do patrimônio de marca”.

Outros modelos de avaliação da marca serão apresentados na próxima seção e podem ser utilizados, isoladamente ou em conjunto, para mensurar o alcance dos resultados esperados com o seu desenvolvimento. Sintetizando as considerações de vários autores, Khauaja (2005, p. 23-24) concluiu que uma marca que tenha desempenhado um processo de construção adequado é aquela que:

- Conta com produtos e serviços na empresa que possuem desempenho e qualidade adequados aos segmentos-alvo;

- É lembrada pelos consumidores potenciais;

- Possui benefício(s) forte(s) e diferenciador(es) para o consumidor-alvo;

- É considerada relevante para atender às necessidades e desejos de um grupo;

- Mantém-se relevante para atender as necessidades e desejos de um grupo;

- É considerada diferente das demais pelos consumidores-alvos;

- Possui uma imagem condizente com a identidade transmitida pela empresa;

- Seu portfólio ajuda a construir sua imagem;

- Possui percepção de qualidade adequada às expectativas dos consumidoresalvos das ações de marketing da empresa; 
- Cria um vínculo de fidelidade com seus consumidores-alvos;

- Garante a lucratividade da empresa, ou pelo menos da unidade de negócio;

- Possui valor patrimonial elevado.

Assim, somente executando uma construção correta e coerente da marca é que se poderá desfrutar de uma marca forte que possa influenciar a percepção do consumidor e a sua tomada de decisão de compra, gerando benefícios tangíveis e intangíveis para a empresa.

\subsection{Patrimônio da marca}

A potencial contribuição da força da marca para criar valor ao cliente e vantagem competitiva estimulou a atenção dos gestores ao patrimônio (ou valor) que ela possui, também denominado de brand equity (CRAVENS; PIERCY, 2007; KAPFERER, 2004). No Brasil, os responsáveis pelas marcas estão começando a se preocupar com esse assunto; prova disso, é que, conforme análise feita pela Interbrand em 2011, as cinco marcas com maior patrimônio - Skol (R\$ 7,28 bilhões), Banco do Brasil (R\$ 11,31 bilhões), Petrobras (R\$ 11,61 bilhões), Bradesco (R\$ 13,63 bilhões) e Itaú (R 24,3 bilhões) - concentram 75\% do valor total das 25 maiores marcas do país, ou seja, ainda há poucas marcas relevantes financeiramente (BORGES, 2011).

O patrimônio da marca é definido por Aaker (1996, p. 7) como o "conjunto de ativos (e passivos) ligados a um nome da marca e a um símbolo, que adiciona (ou subtrai) valor oferecido por um produto ou serviço aos seus consumidores”. Assim, de acordo com Serralvo e Furrier (2005, p. 1), o “valor de uma marca provém da sua habilidade em ganhar um significado exclusivo, destacado e positivo na mente dos clientes”.

O valor oferecido adicionado ou subtraído pela marca, segundo Kotler e Keller (2006, p. 270), "pode se refletir no modo como os consumidores pensam, sentem e agem em relação à marca, bem como nos preços, na participação de mercado e na lucratividade que a marca proporciona à empresa”. A gestão do patrimônio das marcas, portanto, deve ser considerada como uma ferramenta essencial para o desenvolvimento da empresa e da sua rentabilidade, especialmente porque a marca precisa de tempo, recursos e consistência nas ações para adquirir, eventualmente, um valor tão alto que os compradores aceitem, sem hesitar, pagar mais pelos produtos que levam o seu nome (ELLWOOD, 2004; KAPFERER, 2004b).

O patrimônio da marca demonstra a sua força quando obtém respostas dos consumidores diferentes daquelas que se obteriam se o mesmo produto ou serviço não fosse identificado pela marca (D’EMIDIO, 2009). Contudo, a marca somente conseguirá 
acrescentar um valor adicional para um produto, caso seja posicionada de um modo que consiga construir uma imagem desejada pelos seus potenciais usuários. Esse requisito é destacado por Kotler (2000, p. 59) por meio da observação de que

muitas empresas criam uma defasagem de valor por não conseguirem alinhar valor de marca com valor para o cliente. [...] Essas empresas têm menos sucesso em entregar valor para o cliente, essencialmente porque seu pessoal de marketing está concentrado no desenvolvimento da marca. Se os clientes de fato receberão a proposta de valor prometida dependerá da capacidade do profissional de marketing de influenciar vários processos centrais.

Como um ativo, a marca é um símbolo de lucros futuros esperados pela empresa, mas o problema é como avaliar o seu patrimônio e mensurar o seu desempenho no mercado (ELLWOOD, 2004). Para isso, muitos modelos foram desenvolvidos, sendo que eles podem ser divididos em financeiros e comportamentais.

A análise financeira é muito utilizada por pessoas dentro e fora da empresa para se tomarem decisões estratégicas sobre aquisições e venda, para fazer acordos de licenciamento e franquia, para direcionar investimentos de acionistas e da própria empresa, entre outras finalidades; devido à sua maior objetividade (ELLWOOD, 2004). Na ótica financeira, a mensuração do valor patrimonial de uma marca, segundo Furrier (2008, p.156), deriva de três variáveis primárias:

a expectativa de geração de fluxo de caixa ou lucro incremental atribuível à força da marca - possibilitada pela preferência de marca; a estimativa do potencial de crescimento das contribuições da marca ao longo do tempo - indicada pela penetração da marca; e o grau de risco ou de volatilidade embutidos nas expectativas de crescimento ou de geração dos fluxos incrementais - inferido, por exemplo, pelos índices de lealdade à marca.

Para calcular o patrimônio de uma marca, o modelo financeiro tende, normalmente, a calcular qual é o fluxo de caixa incremental proporcionado pela marca, analisa a taxa de crescimento dele ao longo dos anos e desconta todos esses fluxos de caixa futuros por uma taxa que representa o custo de oportunidade da empresa - ou o custo de capital - acrescentado do grau de risco da marca, o que resulta no seu valor presente. Essa é uma forma de avaliação que, embora seja simples, é bem aceita entre as empresas e especialistas, embora não considere diversos benefícios propiciados pela marca que possuem um valor difícil de medir.

Existem outros modos de valoração de uma marca que utilizam parâmetros diferentes e que não são largamente aceitos pelas empresas e especialistas. Um dos métodos é o de 
avaliação da marca que se baseia no custo para criá-la, ou seja, o valor da marca seria igual ao montante despendido para criá-la ou que seria necessário para recriar uma marca semelhante; porém, esse modo de cálculo do valor da marca é muito básico e desconsidera o seu poder mercadológico (D’EMIDIO, 2009; LAMBIN, 2000).

Outro modelo é o de avaliação baseado em mercado que calcula o valor da marca mediante a dedução do valor dos ativos tangíveis da quantia total da venda de uma marca semelhante - não necessariamente realizada pela mesma empresa - ou do valor de mercado da empresa ou de outra que tenha ações em bolsa e possua uma única marca, a qual deve ser semelhante à estudada; e posterior alocação da quantia do valor dos ativos intangíveis resultante que é atribuível à marca (D’EMIDIO, 2009; LAMBIN, 2000). Esse método é muito contestado porque é difícil de serem obtidas as informações de operações realizadas por empresas de capital fechado, ou seja, que não são listadas em bolsa; o modelo desconsidera o entendimento de que cada marca é única e, desse modo, cada qual tem o seu valor; e é muito difícil alocar qual é a quantia dos ativos intangíveis que é relativa à marca.

Portanto, em linhas gerais, o valor de marca deriva, sob o ponto de vista financeiro, da habilidade de, por ações táticas e estratégicas, gerar lucros correntes e futuros superiores aos da concorrência e com riscos mais baixos. Contudo, como apresentado, não existe nenhum modelo financeiro de cálculo do valor de marca que possua plena aceitação e não se constatou evidência empírica sobre a maior validade de um método sobre o outro (D’EMIDIO, 2009).

Dado que a marca é um ativo intangível, a compreensão do efetivo valor da marca está centrada nas percepções do consumidor final em relação a ela; assim, a avaliação econômicofinanceira não consegue captar todos os benefícios gerados por ela e, desse modo, acaba subestimando o valor da marca (D’EMIDIO, 2009). Com a finalidade de auxiliar na correta criação de valor, muitos modelos de avaliação não-financeira do valor da marca, também conhecidos como comportamentais, foram criados, sendo um deles o de Aaker (1996), que considera como pilares do patrimônio da marca os itens: conscientização, fidelidade, qualidade percebida, associações relativas à marca, como patentes, entre outros ativos.

Nesse modelo, de acordo com Ellwood (2004, p. 248), “o termo 'valor’ é usado para caracterizar o valor total da marca para uma empresa, o que reflete a natureza correta e integrada do que uma marca representa para a empresa acima de um artigo genérico”. Para executar a mensuração do valor da marca com este método, Aaker e Joachimsthaler (2007) sugerem indicadores para avaliar cada um dos pilares:

- Fidelidade: preço diferenciado e satisfação do cliente;

- Qualidade percebida: percepção de qualidade e liderança/popularidade; 
- Associações relativas à marca: percepção de valor, personalidade de marca e associações organizacionais;

- Conscientização: familiaridade da marca; e

- Outros ativos: entre as possíveis métricas tem-se a participação de mercado e a cobertura de mercado.

Essas dimensões de valor são importantes, pois proporcionam valor para os clientes por meio da facilitação do processamento de informações sobre o produto/serviço, redução da insegurança em relação à oferta e aumento da satisfação do consumidor; além de gerar valor para a empresa mediante o aumento da eficiência dos programas de marketing, redução da elasticidade da demanda, maiores margens de lucro, vantagem competitiva, facilidade para lançamento de novos produtos, entre outros exemplos (AAKER, 1996).

A consultoria IPSOS-ASI (2010), especialista em assuntos de marketing, mede o valor da marca por meio de cinco características: relevância, popularidade, qualidade, diferenciação e familiaridade. A relevância diz respeito, segundo Furrier (2008, p. 144), ao "grau de importância que a marca tem para as pessoas, isto é, valores atribuídos à marca, seu prestígio e seu grau de reconhecimento”, ou seja, avalia, de acordo com Khauaja (2005, p. 20), se “o consumidor se identifica com a marca e se ela satisfaz as suas necessidades”.

A popularidade de uma marca é decorrente da percepção das pessoas sobre o grau de aceitabilidade e uso dela na sociedade e dos sentimentos de simpatia e agradabilidade despertados por ela (FURRIER, 2008; KHAUAJA, 2005). A qualidade assume o sentido de produtos que atendam adequadamente tanto as necessidades físicas quanto emocionais, do consumidor conforme prometido e comunicado pelo posicionamento da marca.

A diferenciação refere-se às associações e atributos da marca que a tornam diferente em relação aos concorrentes e o grau dessa distinção para os consumidores. E a familiaridade representa o nível de conhecimento dos consumidores sobre a marca e se entendem o que ela oferece (KHAUAJA, 2005).

Já a consultoria Young \& Rubicam (Y\&R), mensura o valor da marca por intermédio do Avaliador de Ativo de Marca (Brand Asset Valuator - BAV), que divide o patrimônio da marca, conforme Aaker (1996) e Kotler e Keller (2006), em quatro conjuntos de medidas: 1) diferenciação: que mede o grau em que uma marca é vista como diferente das outras; 2) relevância: mede se a marca tem relevância pessoal/significado para o consumidor; 3) estima: mede o quanto a marca é conceituada e reconhecida como a melhor em sua categoria (essa medida é altamente relacionada à qualidade percebida e à extensão na qual a marca está 
crescendo em popularidade); 4) conhecimento: mede o quanto os consumidores se sentem familiarizados e íntimos da marca e da sua promessa.

Juntas, a diferenciação e a relevância determinam a força da marca, indicando o valor futuro que ela terá, em vez de apenas refletir seu passado, enquanto que a estima e conhecimento formam a reputação da marca, uma espécie de "boletim” do desempenho anterior (KOTLER; KELLER, 2006).

Os modelos da IPSOS-ASI e da Young \& Rubicam são bem parecidos, sendo que ambos mensuram os fatores diferenciação e relevância, e os fatores qualidade e familiaridade, no primeiro modelo, são parecidos, respectivamente, com os fatores estima e conhecimento, presentes no último modelo. A diferença entre os modelos acaba resumindo-se ao fator popularidade que é mensurado no modelo da IPSOS-ASI, mas é superficialmente estudado no modelo da Y\&R por meio do fator estima.

O valor da marca também pode ser medido pelo modelo escrito por Keller (2002), no qual o patrimônio deriva de uma estrutura de quatro níveis sequenciais baseados no consumidor, demonstrada na ilustração 3, os quais se originam do método de construção de marca desenvolvido por ele. O primeiro patamar é a saliência da marca, que se relaciona ao nível em que a marca é conhecida e atende as necessidades dos consumidores. Nesse nível, o objetivo, segundo Kotler e Keller (2006, p. 274), é “assegurar a identificação da marca entre os clientes e sua associação na mente deles, valendo-se de uma classe de produtos ou de uma necessidade do cliente".

O segundo nível é o do significado da marca, o qual é formado pelo desempenho do produto (como preço, design, durabilidade) e pela imagem criada pela marca (personalidade, valores sociais, situação de uso e compra). A intenção nessa etapa é, de acordo com Kotler e Keller (2006, p. 274), “estabelecer com solidez a totalidade do significado da marca na mente dos clientes, vinculando estrategicamente a ela uma quantidade de associações tangíveis e intangíveis".

O terceiro estrato desta pirâmide são as respostas adequadas dos clientes em relação à marca, medida esta que é composta pelos julgamentos de credibilidade, qualidade, superioridade e pelos sentimentos que os consumidores possuem em relação à marca (diversão, segurança, excitação). O último nível é o do relacionamento que a marca gera com o consumidor e é caracterizado pela lealdade, engajamento, participação da comunidade de usuários, mostrando que o consumidor realmente se sente representado pela marca.

Este modelo de Keller é bem completo, pois, assim como o modelo de Aaker, associa o patrimônio de marca com as vantagens comerciais auferidas por uma posição diferenciada; 
contudo, ele vai além e não foca somente na marca, mas observa também o relacionamento dela com o produto e com os seus usuários (FURRIER, 2008).

\section{Ilustração 3: Pirâmide do patrimônio da marca baseado no consumidor}

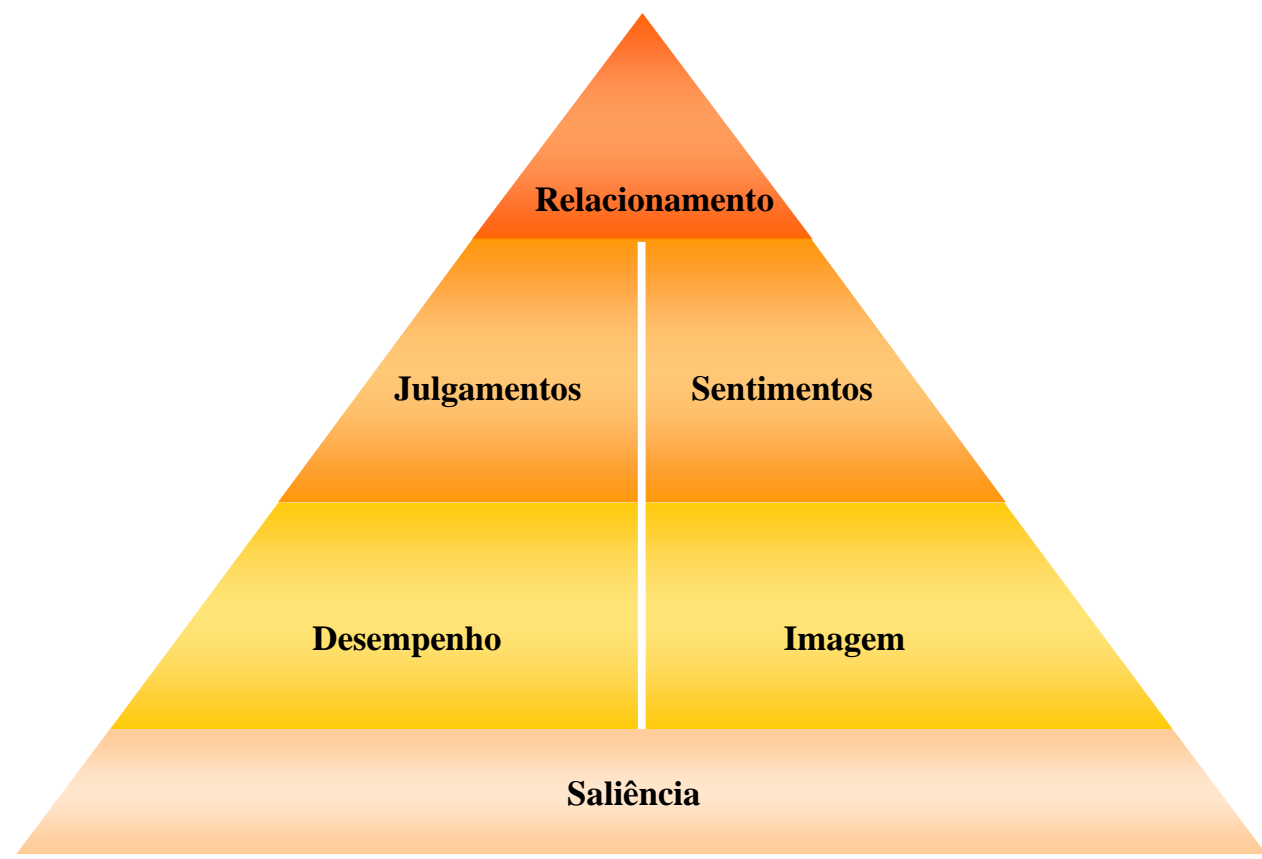

Fonte: Keller (2002, p. 76)

O Brandz, modelo da agência Ogilvy do grupo WPP, representa o valor das marcas por uma pirâmide de cinco níveis - cada um representando o quanto a marca captura do share of wallet dos consumidores, sendo que esse aumenta conforme se avança nos estratos - os quais, em ordem crescente, são: taxa de presença na mente do consumidor (familiaridade com a marca baseada em experiência anterior, saliência ou conhecimento da promessa da marca), relevância (a marca é relevante para as necessidades do consumidor, e possui o correto nível de preço), desempenho percebido (a marca possui um desempenho aceitável), vantagens percebidas (a marca possui vantagens racionais ou emocionais em relação às concorrentes) e vínculo (ligação racional e emocional com a marca, o que leva à exclusão da maioria das outras marcas da mente do consumidor) (BRANDZ, 2009; KAPFERER 2004).

O EquiTrend, método desenvolvido pela consultoria Total Research, avalia o valor de uma marca por meio da saliência (a porcentagem de respondentes que têm uma opinião sobre a marca), assim como o modelo de Keller (2002); da qualidade percebida e da satisfação do usuário (AAKER, 1996).

Três outros modelos para medir o valor da marca são apresentados por D’Emidio (2009): 
- Método de Yoo e Donthu: escala multidimensional baseada em Aaker (1996) e que mede o valor da marca apenas por meio da lealdade, qualidade percebida e lembrança/associações da marca;

- Modelo de Biel: considera o valor da marca como dependente da imagem que é percebida pelo consumidor, ou seja, do conjunto de atributos e associações que os consumidores conectam com o nome da marca, sendo que essa imagem é dividida em corporativa, do usuário da marca e do produto/serviço; e

- Método de Lassar: avalia a marca com base na opinião de seus consumidores, apenas em relação à sua qualidade percebida (ou desempenho da marca), imagem social, comprometimento, valor percebido e credibilidade.

Portanto, em linhas gerais, conforme Hoeffler e Keller (2002, p.78), “as abordagens teóricas [não-financeiras] interpretam, de um modo ou de outro, os efeitos da gestão da marca sobre o conhecimento do consumidor em relação à marca e como que esse conhecimento afeta o comportamento do consumidor”, sendo o modelo de Lassar uma exceção a essa afirmação.

Conforme apresentado, os itens mais comuns nos modelos comportamentais de avaliação do patrimônio da marca são as associações de marca, a qual pode ser criada por meio do seu posicionamento; a qualidade percebida e a fidelidade/vínculo com o cliente, atributos esses extrínsecos ao produto, pois estão mais associados à resposta e percepção do consumidor do que às características reais da oferta (D’EMIDIO, 2009).

Devido à forte ligação com medidas do campo do marketing, os modelos comportamentais tendem a tornar imprecisa a contabilidade financeira da marca (ELLWOOD, 2004). Assim, é interessante notar que os modelos que estão sendo efetivamente adotados por empresas e instituições de avaliação de ativos são uma mistura dos modelos financeiros e comportamentais, resultando em modelos monetários direcionados pelo comportamento do consumidor em relação à marca (D’EMIDIO, 2009).

Em resumo, diversos modelos de avaliação do valor da marca foram desenvolvidos todos com suas vantagens e limitações específicas - a fim de mensurar adequadamente esse ativo e guiar os gestores sobre quais medidas tomar para maximizar as dimensões do brand equity, pois ter um nome de marca forte confere certas vantagens aos proprietários da marca. 


\subsection{Benefícios da marca para a empresa}

Marcas fortes podem desfrutar de diversos benefícios que influenciam positivamente na sua avaliação de valor e, consequentemente, acabam gerando um retorno financeiro maior e mais constante para a empresa, protegendo-a em períodos de baixa demanda e de guerra de preços.

Quando eram vistas como uma ferramenta meramente burocrática, usada só para facilitar as transações, as marcas tinham como benefício: 1) a indicação da fonte ou origem de produtos e serviços; 2) a distinção dos produtos e serviços de uma empresa; 3) uma pequena representação do valor intrínseco da empresa proprietária da marca registrada, servindo como indicativo de qualidade de seus produtos e serviços (KOTLER; KELLER, 2006; PEREZ, 2004).

Com a ampliação da visão do valor da marca, novos benefícios da marca para a empresa foram descobertos, como a proteção dos produtos contra imitações e falsificações; a diferenciação, identificação e localização do produto no ponto-de-venda; a possibilidade de extensões; e a facilidade para o lançamento de novos produtos (LAMBIN, 2000; PEREZ, 2004).

Outros benefícios da marca para a empresa, adicionados por Khauaja e Prado (2008), são que ela: permite segmentação do mercado, localiza o produto no ponto de venda e facilita o processo de decisão e escolha do consumidor. Já Keller (2002) e Aaker e Joachimsthaler (2007) observam que a marca promove a geração de fidelidade do consumidor em relação à marca, a possibilidade de cobrar preços diferenciados (o que resulta em maiores margens) e o aumento da qualidade percebida. Kapferer (2004a, 2004b) também cita a fidelidade dos consumidores em relação à marca e acrescenta a redução do risco percebido, tanto financeiro quanto físico e emocional, que a marca promove em toda a sua cadeia de compra e consumo, visto que ela associa o seu nome a satisfações garantidas decorrentes de experiências passadas positivas.

Em consonância com Khauaja e Prado (2008) e Keller (2002), Cravens e Piercy (2007) citam que marcas bem administradas facilitam a fidelidade a elas; a introdução de novos produtos no mercado, devido à familiaridade com a marca; a eficiência promocional, ao prover um ponto focal; a fixação de preços diferenciados; e a segmentação de mercado.

Além da fidelidade e dos preços diferenciados, Lambin (2000) comenta que uma marca influente possui fraca sensibilidade ao preço, ou seja, resiste melhor a aumentos de preço em relação às marcas concorrentes, o que seria uma consequência da fidelidade e um requisito para se implementarem preços diferenciados; além de desfrutar de atitudes positivas dos consumidores, como familiaridade, estima, preferência, intenção de compra. 
Além de todos esses benefícios, ao associar a marca com uma causa social, Hoeffler e Keller (2002) adicionam mais quatro dividendos para a marca e, consequentemente, à empresa, os quais são:

- Constrói consciência sobre a marca: devido à maior exposição, como resultado da aliança com uma causa, haverá um aumento no conhecimento, por parte do público-alvo, das empresas e das marcas envolvidas;

- Melhora a imagem da marca e da empresa: a marca social possibilita aos consumidores o desenvolvimento de uma imagem positiva do perfil dos usuários da marca aos quais eles podem, também, aspirar; melhora a dimensão de sinceridade da marca e da empresa e, desse modo, os consumidores podem perceber as pessoas por trás da marca como atenciosas e verdadeiras; além de gerar diversos tipos de julgamentos e sentimentos positivos dos consumidores que podem, também, serem associados à marca;

- Estabelece credibilidade para a marca: a marca social pode afetar a credibilidade da marca por meio da melhoria das considerações dos consumidores sobre a expertise, confiabilidade e atratividade/apelo da marca, dado que os consumidores podem perceber a empresa como desejosa em investir em uma causa como forma de preocupar-se mais com os consumidores e de mostrar que é confiável, pelo menos no sentido amplo, e, além disso, interessada em "fazer as coisas certas”;

- Evoca sentimentos em relação à marca: quando os consumidores acreditam que a causa cria um imaginário favorável para a marca, sentimentos de aprovação social podem emergir, assim como sentimentos de auto-respeito, pela transmissão para as pessoas da noção de que elas estão fazendo as coisas certas e que elas devem sentir-se bem sobre elas mesmas por estarem fazendo isso.

Assim, embora antigamente as marcas fossem vistas como gastos necessários, pois geravam benefícios funcionais tanto para os fornecedores quanto para os consumidores, agora elas estão sendo utilizadas com outra mentalidade. Atualmente as marcas são aceitas como ativos intangíveis e, desse modo, os desembolsos de caixa nelas não são mais despesas, mas sim investimentos, dado que atualmente é sabido que além do caráter funcional, elas também têm funções emocionais, sociais e psicológicas que influenciam na tomada de decisão de compra do consumidor e podem gerar enormes benefícios financeiros para as empresas. 
Por fim, os benefícios para a empresa mais citados pelos principais autores do tema de marcas, como Keller (2002), Hoefler e Keller (2002), Kotler e Keller (2006), Aaker (1996), Aaker e Joachimsthaler (2007) e Kapferer (2003, 2004a, 2004b), foram a fidelidade do consumidor à marca, a possibilidade de se cobrar preço diferenciado e o aumento da qualidade percebida, os quais, devido à relevância, serão mais detalhados a seguir.

\subsubsection{Fidelidade}

Nos mercados maduros, que são a maioria dos casos, o crescimento do valor da marca consequentemente, da empresa - não se dá mais por meio das estratégias extensivas ou expansivas, mas sim das intensivas, aumentando a intensidade do vínculo entre o consumidor e a marca, mediante a compreensão dos interesses do consumidor, do alinhamento aos seus valores, sua ética, seus interesses e desejos, fazendo com que ele goste da marca, tornando-se fiel a ela e, desse modo, passando a consumí-la em maior quantidade e com mais frequência (KAPFERER, 2004a).

As empresas reequilibraram os seus objetivos de mercado para menos conquista e mais fidelização, pois a preocupação com o volume e participação de mercado só tem sentido se houver lucro; portanto, a receita (ou consumo) per capita deve ser uma das principais metas para aumentar o valor da marca (e, em decorrência, da empresa); logo, deve haver uma concentração dos esforços de marketing na fidelização dos clientes (KAPFERER, 2004a). As marcas líderes do mercado, segundo Kapferer (2004a, p. 115), “desfrutam de uma penetração mais forte que as outras e, ao mesmo tempo, também de uma taxa de fidelidade mais alta e de um maior volume de consumo per capita”.

Assim, a fidelidade é um benefício-chave para geração de valor para a marca e referese ao aumento do consumo da marca pelo consumidor e a escolha repetida dela nas sucessivas situações de compra (AAKER, 1996; ELLWOOD, 2004; LAMBIN, 2000). Um conceito alternativo de fidelidade à marca é proposto por Jakoby e Kyner (apud LAMBIN, 2000, p. 213) e a estabelece como “a resposta comportamental, não aleatória, expressa através do tempo, por uma unidade de decisão a uma ou mais marcas [...] [de] um conjunto de múltiplas marcas e que resulta de um processo psicológico de evolução”. Essa definição é interessante, mas é controversa, pois ela defende a possibilidade da multifidelidade, que seria o vínculo por mais de uma marca em um conjunto de alternativas, o que, por outro lado, pode ser visto como a inexistência de fidelidade às marcas e sim de preferência por elas, que seria um estado de menor intensidade de vínculo emocional. 
É possível identificarem-se dois tipos de fidelidade, uma racional e outra emocional (KAPFERER, 2004b). A primeira relaciona-se aos casos em que o consumidor percebe algum benefício material em permanecer fiel à marca, como um desconto por frequência de compra e os programas de bônus desenvolvidos pelas empresas. Já a fidelidade emocional não exclui o vínculo dos consumidores à marca decorrente das vantagens materiais, mas poderia dispensá-las por pura identificação deles com a marca e reconhecimento dos benefícios intangíveis dela.

O valor da marca para uma empresa é largamente criado pela fidelidade do cliente. Conforme Kapferer (2003, p. 160), uma marca “só será forte se ela tiver uma taxa elevada de clientes grandes e fiéis”. Esta relação entre fidelidade do consumidor à marca e o seu valor decorre do fato de que uma base de clientes altamente fiéis à marca gera um fluxo previsível de vendas e lucro (KOTLER; KELLER, 2006; FURRIER, 2008). Na verdade, uma marca sem uma base de clientes fiéis é, normalmente, vulnerável ou tem valor somente em seu potencial de criar clientes fiéis (AAKER, 1996).

Além de gerar receita, a lealdade à marca impacta também nos custos de marketing, pois reter um cliente fiel custa cinco vezes menos do que conquistar um novo (KOTLER; KELLER, 2006). Por esse motivo, a lealdade dos atuais clientes também representa uma barreira de entrada substancial para os competidores e, desta forma, acaba-se evitando gastos desnecessários, como em campanhas publicitárias para ofuscar os movimentos dos concorrentes (KOTLER; KELLER, 2006). A fidelidade dos clientes à marca também pode gerar um comportamento de resistência no que se refere a contratempos e simplificar o processo de compra do produto/serviço ao gerar familiaridade e confiança ao consumidor (FURRIER, 2008; KAPFERER, 2004a).

Talvez a mais forte demonstração de fidelidade à marca é quando um consumidor deseja investir tempo, energia, dinheiro ou outros recursos na marca, além daquele gasto durante a compra ou o consumo da marca (HOEFFLER; KELLER, 2002; KELLER 2002). Chamado de bonding pelos anglo-saxões, esse intenso vínculo,

\footnotetext{
feito de sentimento de exclusividade, de insubstituibilidade, tanto para os benefícios tangíveis como pelos valores intangíveis, cria uma comunidade de pessoas que se deve qualificar mais como adeptos do que como clientes. Mais do que em fidelidade, deve-se falar aqui em comprometimento recíproco. O ideal de cada marca é criar esse vínculo indefectível e único (KAPFERER, 2004a, p. 159).
}

As comunidades de marca são formadas por clientes-fãs comprometidos com a marca, que percebem compatibilidade de metas grupais e individuais, indo além da simples 
correspondência de atributos, imagens e personalidade com seus referenciais, e que possuem o desejo de compartilhar experiências - gerando propaganda boca a boca - e de se sentirem pertencentes a um grupo com o qual possuam alguma afinidade ou afiliação, desenvolvendo, desse modo, um engajamento ativo com a marca (FURRIER, 2008b; HOEFFLER; KELLER, 2002; KHAUAJA, 2008).

Essas comunidades são importantes para as empresas, pois na sociedade pós-moderna, a transmissão dos hábitos e costumes se faz cada vez mais pelos semelhantes e não pela família; assim, o compartilhamento de experiências das outras pessoas com interesses semelhantes e que participam do mesmo grupo auxilia no desenvolvimento da fidelidade à marca por parte de um novo consumidor (KAPFERER, 2004a).

No caso de marcas sociais, uma causa bem escolhida pode servir, dependendo dos tipos de associações, julgamentos e sentimentos criados, como um ponto de união para os usuários da marca e um significado para conectá-los ou incentivá-los a trocar experiências com outros consumidores ou empregados da companhia (HOEFFLER; KELLER, 2002).

O valor de uma marca, de acordo com Kapferer (2004, p. 121), “é medido pela sua capacidade de criar um vínculo de fidelidade perene com o consumidor, em certo nível de preço”. Segundo Aaker (1996, p. 320), “um indicador básico de lealdade é a quantia que um consumidor pagará por uma marca em comparação com outra marca, oferecendo os mesmos benefícios ou piores”.

Outras possíveis medidas de fidelidade são o valor presente dos ganhos trazidos pelos clientes ao longo do relacionamento com a marca, a porcentagem das ocasiões de compra em que a marca foi lembrada e o histórico da quantidade adquirida pelo comprador (KAPFERER, 2004b). Porém, a primeira métrica é difícil de implementar, pois exige a estimativa dos ganhos futuros advindos dos clientes e a definição da taxa de desconto para trazê-los para o presente. Já o segundo indicador mede mais o grau de lembrança da marca, ou seja, a presença dela no grupo de consideração do consumidor, e não necessariamente a fidelidade a ela. E o histórico de quantidade adquirida pelo consumidor é falho, porque pode não desconsiderar outros fatores, além da lealdade, que afetam essa medida, como o crescimento da família ou a descoberta de novas situações de uso para a marca.

Portanto, a medida sugerida por Aaker (1996) é mais adequada para a medição da fidelidade à marca, pois ele fornece o grau de diferenciação da marca e o quanto ela é essencial para a pessoa. A quantia a mais paga por uma marca forte ocorre porque a relação que o consumidor acaba tendo com ela é de dependência, o que gera uma demanda inelástica da marca, reduz a sensibilidade de preço do consumidor e abre uma oportunidade para 
geração de outro benefício das marcas para as empresas, a aplicação de um preço diferenciado (KOTLER; KELLER, 2006; LAMBIN, 2000).

\subsubsection{Preço diferenciado}

A oferta e a comunicação das empresas foram construídas em torno de marcas que herdam, com o tempo, valores imateriais, significados e representações que as diferenciam e levam os clientes a apresentarem uma relação de dependência por elas e, desse modo, uma fraca sensibilidade ao preço, que os faz pagarem mais caro em comparação aos concorrentes diretos e ao preço justo da oferta, o que ultrapassa a simples realização das funcionalidades do produto (CRAVENS; PIERCY, 2007; KAPFERER, 2004; LAMBIN, 2000).

A marca é um valor agregado do invisível, impalpável, daquilo que se esconde sob os benefícios materiais. Normalmente, é por esse valor agregado que o comprador está disposto a pagar. Razão pela qual, aliás, às vezes se avalia o valor financeiro de uma marca medindo-se a diferença de preço que o consumidor está disposto a pagar para adquirir o produto dessa marca em comparação a um idêntico, mas sem marca, ou de uma marca desconhecida (KAPFERER, 2004).

Uma marca forte gera maiores retornos em lucratividade para a empresa, devido à possibilidade de se cobrar um preço diferenciado, o qual é, normalmente, 20 a 25 por cento maior do que o preço justo (FURRIER, 2008b; KOTLER; KELLER, 2006; SERRALVO; FURRIER, 2005). O preço diferenciado é o benefício econômico mais explícito de uma marca e tem correlação significativa com o desempenho financeiro nas perspectivas de longo prazo da empresa (FURRIER, 2008b). Ele representa a possibilidade de a empresa receber uma maior margem líquida por um produto.

Reforçando este ponto, Aaker (1996, p. 321) afirma que

\footnotetext{
o preço [...] [diferenciado] pode ser a melhor medida individual disponível do patrimônio da marca, porque ele captura diretamente a lealdade dos consumidores de um modo relevante. Se eles são leais, eles devem logicamente estar desejando pagar um preço [...] [diferenciado]; se eles não desejam pagar mais, o nível de lealdade é baixo.
}

As economias de mercado livre encorajam e permitem que as marcas sejam bemsucedidas com base no preço que o consumidor está disposto a pagar pela marca (um valor acima de qualquer preço de mercadoria de referência); porém, vale ressaltar que apesar de ser afirmado que as marcas fortes podem cobrar um preço diferenciado, a sensibilidade dos 
consumidores, na verdade, varia caso a caso, de acordo com as marcas, e isto influencia na propensão de pagar o preço mais alto ou não (ELLWOOD, 2004; KHAUAJA, 2005).

Nenhuma fidelidade à marca é incondicional e o preço é um importante sinalizador do valor da marca, desenvolvendo no consumidor uma expectativa do quanto se é possível receber de qualidade e benefícios por aquele preço (ELLWOOD, 2004; FURRIER, 2008b). Assim, é essencial ter uma política de preço adequada ao que a marca oferece. Ao mesmo tempo em que uma posição consolidada de marca permite a prática de preços diferenciados, um preço elevado demais em relação à qualidade e aos benefícios percebidos pelo consumidor gera a sua frustração (FURRIER, 2008b). Já um preço subestimado resulta na desvalorização da marca em comparação às semelhantes, o que é difícil de ser contornado posteriormente, pois se cria um ciclo descendente em que a redução do lucro leva ao menor investimento em comunicação e qualidade do produto o que reduz ainda mais as vendas e, consequentemente, o lucro (ELLWOOD, 2004).

Assim, o preço diferenciado tem uma relação causal mútua com outro benefício que a marca gera para a empresa, que é o aumento da qualidade percebida. O preço diferenciado de uma marca tenderá a influenciar a qualidade percebida de um produto quando outros sinalizadores não estiverem disponíveis; assim, quanto maior o preço de um produto, maior seria a sua qualidade (AAKER, 1996, AAKER; JOACHIMSTHALER, 2007). Porém, o preço diferenciado somente se sustentará se a marca conseguir transmitir uma qualidade percebida maior.

\subsubsection{Aumento da qualidade percebida}

Outro benefício gerado pela marca para a empresa é o aumento da qualidade percebida. De acordo com D’Emidio (2009, p. 19-20), “a qualidade percebida é o conhecimento que o consumidor tem da qualidade geral ou superioridade de um produto ou serviço pretendido, em comparação a alternativas”.

Assim, nem sempre a qualidade que uma empresa entrega é a mesma que o consumidor avalia ter recebido. Se uma empresa entrega uma qualidade maior do que a percebida, significa que ela está investindo mal os seus recursos, desperdiçando-os. Entretanto, quando a qualidade entregue é menor que a percebida, isto leva a crer que a empresa utilizou tão bem seus recursos que geraram um resultado alavancado, ou seja, maior do que seria em condições normais.

Como visto anteriormente, a fixação de preço tem relação mútua de potencialização e sustentação com a qualidade percebida, visto que o preço, na ausência de outros fatores, pode ser um indicativo de qualidade do produto (AAKER; JOACHIMSTHALER, 2007). Assim, é necessário ter uma cuidadosa gestão da combinação desses dois fatores, pois, se uma empresa 
superestimar o preço da marca, pode-se gerar a expectativa de uma qualidade acima da real e, desse modo, frustrar o consumidor. Por outro lado, um preço baixo pode transmitir a idéia de uma marca de baixa qualidade, levando a um ciclo - difícil de corrigir - de corrosão dos lucros da empresa e deterioração da marca.

E, assim como ocorre entre a fidelidade e o preço diferenciado, a relação da primeira com o aumento da qualidade percebida existe somente em um sentido; porém, nesse caso, é a qualidade percebida que impacta a fidelidade, pois produtos de marca com alta qualidade percebida têm maior probabilidade de gerar compra repetida, ou seja, fidelidade (CALDWELL; COSHALL, 2002). Assim, a ilustração 4 mostra uma idéia de como os três benefícios da marca para a empresa interagem em um ciclo que, dependendo da gestão da marca, pode ser virtuoso ou destrutivo.

\section{Ilustração 4: Ciclo de relacionamento dos benefícios da marca para a empresa}

Fidelidade

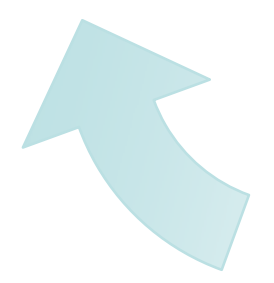

Preço diferenciado

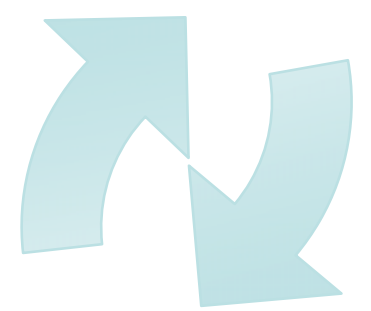

Qualidade Percebida

A qualidade percebida é ampliada pelas marcas fortes, pois a pessoa passa a entender que não são somente os itens tangíveis (como desempenho, durabilidade, forma e acabamento do produto) que a marca está entregando, mas também aspectos emocionais, intangíveis, que aumentam a qualidade, embora não possam ser avaliados fisicamente. Outro motivo para essa percepção alavancada é o fato de que o consumidor interpreta o alto investimento de marketing na marca e o alto preço dela como indicativos de qualidade do produto (AAKER, 1996). 
Este relacionamento entre marca forte e alta qualidade é feito muito comumente na compra de produtos e serviços complexos (como cremes anti-idade, cirurgias médicas, cortes de cabelo) que possuem itens de difícil avaliação. Como os consumidores raramente têm todas as informações necessárias para fazer um julgamento racional e objetivo sobre a qualidade - e mesmo que eles tenham as informações, eles podem não ter tempo e motivação para processá-las - eles confiam em uma ou duas pistas que associam com a qualidade (MOWEN; MINOR, 2003). As marcas podem ser um desses sinalizadores de qualidade e, dessa maneira, consumidores satisfeitos podem facilmente optar novamente pelo produto (KOTLER; KELLER, 2006).

Destacando a importância deste benefício gerado pela marca, Aaker (1996, p. 17-19) afirma que a "qualidade percebida está normalmente no coração do que os clientes estão comprando e, neste sentido, ela é uma medida básica do impacto de uma identidade de marca” e diz ainda:

1) entre todas as associações da marca, somente qualidade percebida tem sido mostrada influenciando o desempenho financeiro; 2) qualidade percebida é frequentemente uma importante (se não a principal) verdade estratégica dos negócios; 3) qualidade percebida é ligada e frequentemente influencia outros aspectos de como a marca é percebida [em um ciclo de reforço positivo]. 


\section{METODOLOGIA}

\subsection{O tipo de estudo}

Para o alcance do objetivo deste estudo foi realizada uma pesquisa exploratória quantitativa com a utilização de dados primários. Enquadrou-se a pesquisa nessa categoria, pois há o objetivo de aumentar o conhecimento sobre algumas características de determinada população, bem como observar as relações entre variáveis e fatos, por meio da utilização de dados que não foram submetidos a nenhuma interpretação e que procurarão refletir as percepções e expectativas das pessoas em relação aos diferentes conceitos de marcas.

Os estudos quantitativos, de acordo com Cooper e Schindler (2003, p. 130), “são voltados para amplitude e não para profundidade. Eles tentam captar as características de uma população ao fazer inferências das características de uma amostra”. E os mesmos autores (2003, p. 136) afirmam que pesquisas descritivas relacionam-se a

- descrições de fenômenos ou características associadas à população-alvo (o quem, que, quando, onde e como de um tópico);

- estimativa das proporções de uma população que tenha essas características;

- descoberta de associações entre as diferentes variáveis; e

- descoberta e mensuração de relações de causa e efeito entre as variáveis

A coleta de opiniões dos clientes em relação a fatores contribuintes para a criação do patrimônio da marca, como a preferência de compra e preço justo da marca, é uma maneira popular de se inferir o valor e a força da marca (FURRIER, 2008, p. 157).

\subsection{População/Amostra: unidades de análise}

A população de interesse corresponde aos brasileiros maiores de 18 anos de ambos os sexos. A escolha de pessoas com 18 anos ou mais foi devido ao fato de que é um grupo que já faz parte da população economicamente ativa e, portanto, possui poder de compra para adquirir bens e serviços.

Foi empregada a amostragem acidental, definida por Martins (2002) como formada por pessoas de possível acesso até se alcançar o número desejado de tamanho da amostra. A quantidade de respostas obtida foi 248, o que corresponderia, em um caso de amostragem aleatória simples, a um nível de confiança de 95\% e a margem de erro de 6,47\%. Para esse 
cálculo, a variável escolhida para a estimativa de proporção da população foi a preferência de compra de um produto com uma marca social ao invés de outras marcas. Segundo Produtos (2008), esta preferência é estimada em torno de 37\%. O universo foi considerado infinito, pois, em 2010, o tamanho da população brasileira com 18 anos ou mais era maior do que 127 milhões, o que permite a adoção da fórmula de dimensionamento de amostra oriunda de um universo infinito (IBGE, 2011).

Em relação à composição da amostra, não houve nenhuma definição de quotas de respondentes por idade, classe social e gênero social, ou seja, escolheram-se os respondentes por conveniência.

\subsection{Coleta de dados}

A coleta de dados foi realizada por meio de uma abordagem pela internet. O plano para a obtenção das respostas consistiu em disponibilizar o questionário em um site especializado, denominado QuestionPro, e divulgá-lo pelo envio do seu endereço, via correio eletrônico, para pessoas conhecidas responderem e para secretarias de alguns cursos de pósgraduação repassarem para os seus alunos, a fim de que eles participassem. Um exemplo da mensagem que foi enviada para as secretarias é apresentado no apêndice 1. Esse levantamento de dados ocorreu em Março de 2011 e, posteriormente, em Julho do mesmo ano, com o objetivo de aumentar o tamanho da amostra.

Escolheram-se por conveniência as instituições contatadas, as quais foram: Fundação João Pinheiro, Universidade Federal da Bahia, Universidade Federal do Espírito Santo, Faculdades Pedro Leopoldo, Universidade Federal de Pernambuco, Universidade Estadual de Maringá, Universidade Federal de Santa Maria, Universidade Metodista de Piracicaba, Universidade do Sul de Santa Catarina, Universidade Paulista, Fundação Getúlio Vargas, Universidade Federal do Rio Grande do Sul, Universidade Federal de Rondônia, Universidade Federal do Rio Grande do Norte, Universidade do Grande Rio, IBMEC-RJ, Universidade Federal do Rio de Janeiro, Universidade Positivo, Pontifícia Universidade Católica do Paraná, Universidade Federal da Paraíba, Universidade Federal de Mato Grosso do Sul, Pontifícia Universidade Católica de Minas Gerais, Universidade Federal de Uberlândia, Universidade Federal de Lavras, Universidade Federal de Viçosa, Universidade Federal de Minas Gerais, Centro Universitário Euro-Americano, Universidade de Brasília, Universidade Estadual do Ceará, Universidade Salvador, Universidade de Cruz Alta, 
Universidade Estácio e Universidade Fundação Mineira de Educação e Cultura. Descartou-se o envio do questionário para alunos da pós-graduação da Faculdade de Economia, Administração e Contabilidade da Universidade de São Paulo (FEA/USP), pois alguns deles já conheciam com mais detalhes o estudo e, desse modo, poderiam enviesar os resultados.

Ademais, foi enviado o arquivo do questionário para a professora doutora Maria Aparecida Gouvêa, a fim de que ela solicitasse o preenchimento do mesmo aos alunos de graduação da disciplina Técnicas Estatísticas de Agrupamento, ministrada na FEA/USP. Esse levantamento ocorreu entre 28 de Março e 11 de Abril de 2011.

O questionário era composto por nove questões fechadas que tratavam sobre características do respondente e opiniões e preferências relativas à compra de camisetas, conforme pode ser visto no apêndice 2. Para avaliar o impacto das marcas sobre a opinião e as preferências de compra de uma pessoa, foi necessário simular uma avaliação de alternativas de compra e, para facilitar esse processo para o entrevistado, decidiu-se pela adoção de um produto, que deveria ser consumível por ambos os sexos e estar presente na realidade de consumo da população em geral. Assim, decidiu-se pelo uso de camisetas para gerar a situação desejada, pois é um item comum para ambos os sexos e acessível para quase todas as classes sociais, reduzindo-se, desse modo, o viés decorrente ao afastamento da realidade dos entrevistados.

Também, optou-se pela camiseta pelo fato de ser, conforme Kotler (2000), um bem de compra comparada, ou seja, durante o processo de seleção e compra, o cliente acaba comparando-a em termos de adequação, qualidade, marca e modelo e é um produto simples, o que possibilita uma avaliação objetiva, características essas diferentes de outros produtos como cosméticos anti-idade e perfumes.

Outro ponto decisivo para a escolha de camisetas foi o fato de elas serem um veículo de comunicação dos valores e personalidade do usuário para a sociedade, ou seja, é um meio de auto-expressão, como apresentado na ilustração 5, onde mensagens são transmitidas por meio de camisetas. Assim, nesse tipo de produto, a marca e os seus significados têm enorme valor, conforme observa Ellwood (2004, p. 204-205) ao relatar que

a aprovação sociológica da marca deriva da satisfação que os clientes obtêm da associação e do reconhecimento do grupo [...]. As roupas de marca são claramente usadas para permitir a inclusão em um grupo social especifico, ou podem excluir as pessoas de um grupo. O que as roupas dizem sobre quem as usa foi traduzido em grande parte no lema "você é o que você usa"; seus companheiros de grupo o reconhecem como alguém da mesma categoria e interagem com você com base em que vocês têm alguma coisa em comum. O fato de usar roupas de uma determinada marca representa uma afirmação de valores que pode ser interpretada pelos outros. [...] Esse tipo de aprovação 
da marca baseia-se no reconhecimento e na compreensão de uma identidade de grupo, para satisfazer as necessidades de socialização. É duvidoso sugerir que um simples distintivo pode definir o nosso caráter, mas as pesquisas sugerem que a maioria das pessoas confia em parte nesse tipo de simbolismo. [...] Os consumidores podem comunicar identidades verdadeiras ou desejadas para o seu grupo.

\section{Ilustração 5: Camisetas como meio de expressão}

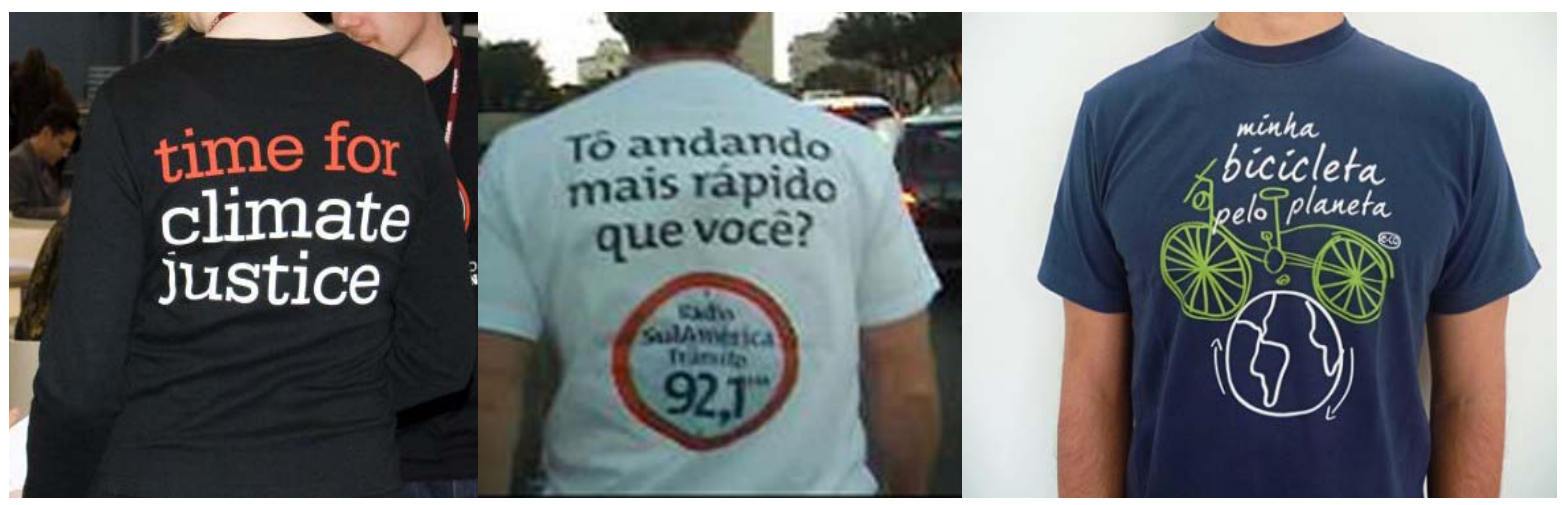

Uma justificativa adicional para a escolha das camisetas é o fato de que nessa categoria de produtos é possível encontrar os três tipos de marcas que são objetos de estudo deste trabalho, como demonstrado na ilustração 6, onde três camisetas muito semelhantes da empresa Hering são diferenciadas pela marca estampada ou pela sua omissão, no caso do produto de marca genérica.

\section{Ilustração 6: Camisetas segundo o tipo de marca}

a)

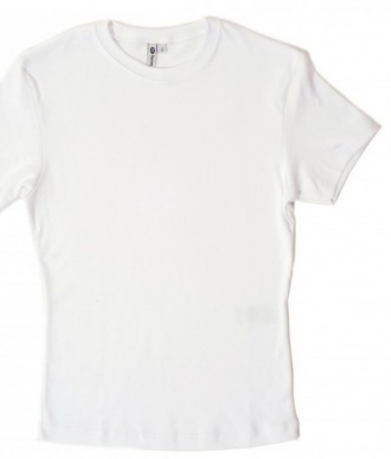

b)

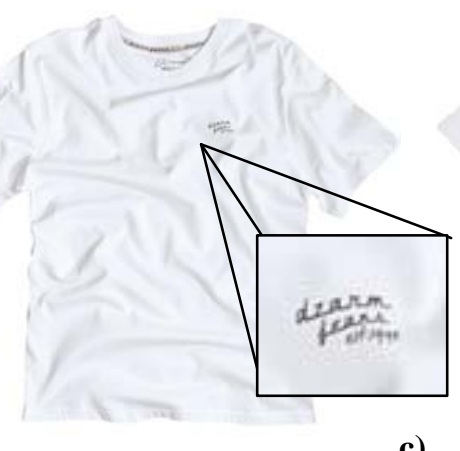

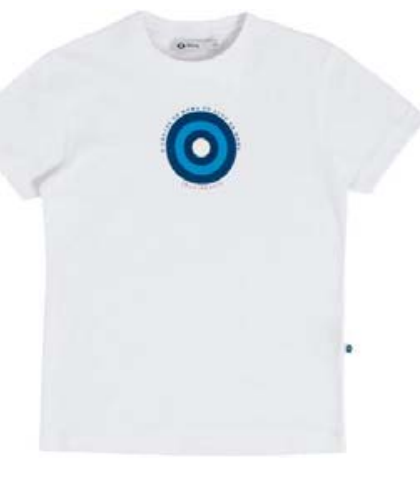

Modelos: a) camiseta de marca genérica, sem qualquer marca visível; b) camiseta de marca de fabricante, com a marca no destaque; c) camiseta de marca social, referente à campanha contra o câncer de mama.

Fonte: Autor baseado em Hering (2011) 
As quatro primeiras perguntas do questionário eram referentes a características do respondente, solicitando informações do gênero sexual, idade, escolaridade e renda familiar, sendo que o fornecimento desse último dado não era obrigatório. As demais questões tratavam das preferências de compra dos participantes em relação a camisetas.

A pergunta cinco solicitava para o respondente ordenar, de acordo com a sua preferência, 12 produtos diferentes, que combinavam os três tipos de marca estudados com três diferentes níveis de preço e qualidade, fatores esses importantes na avaliação de alternativas de compra, muito comuns nos modelos para a construção do valor da marca - por estarem mais associados à resposta e percepção do consumidor - e apontados por autores como Keller (2002), Kotler e Keller (2006), Perez (2004), Aaker (1996), Aaker e Joachimsthaler (2007), Kapferer (2003, 2004a, 2004b), entre outros, como capazes de influenciarem as marcas e serem influenciados por elas. Os produtos avaliados nessa questão foram apresentados aos respondentes em ordem aleatória, a fim de se evitar o viés decorrente da sequência de exposição dos objetos.

Uma camiseta branca de manga curta sem estampas, outra com o símbolo de uma famosa causa social estampado na frente e uma terceira com o logo de uma marca de roupas, que faz muitos comerciais na televisão, estampado na face frontal, foram as descrições que representavam, respectivamente, produtos de marca genérica, social e de fabricante.

Já os níveis de preço e qualidade utilizados foram baixo, médio e alto, evitando-se, desse modo, medidas numéricas, pois, como a população de interesse era heterogênea em diversas características (inclusive renda), uma medida desse tipo poderia ter diferente interpretação para cada pessoa, por exemplo, o preço de $\mathrm{R} \$ 30$ poderia ser considerado alto por alguns e baixo por outros. Assim, para que a medida fosse interpretada da mesma forma por todas as pessoas, optou-se por níveis não-numéricos, que, embora possam representar valores diferentes para pessoas diferentes (por exemplo, o nível de preço alto pode ser R\$100 para uma pessoa e R \$ 30 para outra), transmitem a mesma mensagem de grandeza para todos, ou seja, dizem se o produto possui preço (ou qualidade) alto ou baixo.

A sexta e sétima questões foram elaboradas para avaliar a diferenciação e a sensibilidade de preço, respectivamente, dos tipos de marca estudados, os quais foram descritos do mesmo modo da pergunta cinco, porém, agora se definiu que a qualidade dos produtos era mediana. Na questão seis era solicitada à pessoa a precificação dos três tipos de camiseta e, na pergunta sete, ela era convidada a estabelecer o quanto deveria custar cada camiseta dos diferentes tipos a fim de que ela levasse duas do mesmo modelo, mas de cores diferentes. 
Por fim, as duas últimas questões foram elaboradas para levantar dados em relação ao perfil de preferência dos respondentes em relação a camisetas, a fim de se realizarem cruzamentos com as informações obtidas no restante do questionário. A questão oito solicitava para o respondente apontar a sua preferência entre três tipos de camiseta, a mais barata, a que é anunciada na TV e a produzida por uma empresa envolvida em causas sociais e/ou ambientais, as quais representavam, respectivamente, atributos simbólicos das marcas genérica, de fabricante e social. Já a questão nove apresentava quatro características das camisetas e solicitava para a pessoa ordená-las segundo a importância deles na decisão de compra de uma camiseta. Esses atributos eram mostrados em ordem aleatória, para reduzir o viés da sequência de exibição.

Visando à adequação do instrumento de coleta de dados aos objetivos do estudo, foi realizado um pré-teste com cinco pessoas, o que permitiu avaliar a adequação do seu conteúdo, a clareza dos textos e o tempo de preenchimento, o qual foi, em média, 11 minutos.

\subsection{Técnicas de análise dos dados}

A seguir serão apresentadas as cinco técnicas estatísticas utilizadas para a geração dos resultados deste trabalho. A relação de cada uma delas com as análises realizadas para o alcance da finalidade proposta para esse estudo, elencados na seção sobre o objetivo do estudo, é apresentada no quadro 3.

\section{Quadro 3: Relação das técnicas estatísticas com as análises realizadas}

\begin{tabular}{|l|c|}
\hline \multicolumn{1}{|c|}{ Análise realizada } & Técnica(s) estatística(s) \\
\hline Importância da marca na preferência de compra de um produto & Análise conjunta \\
\hline $\begin{array}{l}\text { Predileção das pessoas diante de produtos de marca social, } \\
\text { genérica e de fabricante }\end{array}$ & Análise conjunta \\
\hline $\begin{array}{l}\text { Relação dos três tipos de marca com o preço justo e a qualidade } \\
\text { percebida do produto }\end{array}$ & $\begin{array}{c}\text { Análise conjunta e teste-t para amostras } \\
\text { relacionadas }\end{array}$ \\
\hline $\begin{array}{l}\text { Fidelidade/inelasticidade criada pela marca social, genérica e de } \\
\text { fabricante }\end{array}$ & $\begin{array}{c}\text { Análise de elasticidade-preço da demanda } \\
\text { e teste-t para amostras relacionadas }\end{array}$ \\
\hline $\begin{array}{l}\text { Existência de grupos de consumidores segundo a preferência } \\
\text { pelos tipos de marca e sensibilidade à qualidade e ao preço do } \\
\text { produto }\end{array}$ & Análise conjunta e de conglomerados \\
\hline
\end{tabular}

\subsubsection{Análise conjunta}

A análise conjunta (ou conjoint analysis) é uma técnica de análise multivariada da estrutura das preferências que permite entender o processo de decisão do consumidor no que 
diz respeito a produtos e marcas (HAIR JR. et al., 2006). Especificamente, solicitando que os consumidores expressem suas preferências ou façam escolhas entre um número de produtos com diferentes atributos, pode-se determinar qual é o sacrifício que uma pessoa consente no que se refere a um atributo para beneficiar uma maior satisfação em outro e, assim, a importância que os consumidores atribuem para cada um deles (HAIR JR. et al., 2006; KELLER, 2002; LAMBIN, 2000).

A medida de preferência calculada por essa técnica é a utilidade, a qual é o conceito fundamental da análise conjunta, pois é o valor relacionado ao julgamento de preferência de um indivíduo que mede o nível de felicidade ou satisfação que ele obtém com uma escolha (HAIR JR. et al., 2006; MANKIW, 2001).

A análise conjunta permite descobrir tipos de atributos que intervêm a diversos níveis e que satisfazem da melhor forma as expectativas dos potenciais compradores; assim, há muitas aplicações, sendo o tradeoff marca-preço uma versão simplificada da aplicação desta técnica (LAMBIN, 2000). A principal limitação desse método é a sobrecarga de informações que pode existir, o que pode incitar o respondente a simplificar a tarefa de escolha, ignorando as variações das características menos importantes, ou até mesmo fazê-lo desistir da participação (LAMBIN, 2000).

Para a execução dessa análise elaborou-se a questão cinco do instrumento de coleta de dados, a qual apresentava 12 produtos formados pela combinação de diferentes tipos de marcas (genérica, de fabricante e social) e níveis de preço e qualidade (baixo, médio e alto), levando o inquirido a comparar os produtos de um modo realista, pois a situação de pesquisa está muito próxima do método que adotaria no seu comportamento de compra.

Esses produtos foram montados utilizando-se a opção orthogonal design do programa estatístico Statistical Package for Social Sciences (SPSS) 9.0, sendo que nove deles são estímulos planejados, utilizados para calcular as utilidades, e três deles são estímulos de validação (holdout), ou seja, são casos julgados pelos respondentes, mas não usados para estimar as utilidades, apenas servindo para confirmar a validade interna delas. Para testar a capacidade preditiva do modelo obtido, dois casos de simulação foram criados para serem utilizados durante a análise dos dados, o que totaliza 14 combinações de produtos que são apresentados no quadro 4.

Da forma como foi elaborada e apresentada, a questão cinco atende às suposições teóricas da análise conjunta de que o comprador percebe um produto como um conjunto de atributos que intervêm num determinado nível e diferenciam as ofertas, e de que o comprador realiza sacrifícios em alguns atributos do produto para beneficiar outros (LAMBIN, 2000). Ela também obedece às seguintes exigências dessa técnica: 
1) serem atributos determinantes da escolha e não só atributos importantes; 2) serem atributos independentes ou não redundantes, ou seja, não sistematicamente correlacionados, a presença de um não implica a presença de outro; 3) descreverem o produto o mais completamente possível, o que implica que o julgamento deve poder apoiar-se no conjunto dos atributos, ou pelo menos nos mais importantes; 4) serem atributos manipuláveis pela empresa que poderá agir sobre o nível de intervenção dos atributos (LAMBIN, 2000, p. 164).

Quadro 4: Estímulos utilizados na análise conjunta

\begin{tabular}{|c|c|c|c|c|}
\cline { 2 - 5 } \multicolumn{1}{c|}{} & Modelo de Camiseta & Preço & Qualidade & Tipo de Estímulo \\
\hline \multirow{5}{*}{} & Z & Baixo & Alta & Planejado \\
\cline { 2 - 5 } & Z & Alto & Média & Planejado \\
\cline { 2 - 5 } & X & Alto & Alta & Planejado \\
\cline { 2 - 5 } & X & Médio & Baixa & Planejado \\
\cline { 2 - 5 } & X & Baixo & Alta & Planejado \\
\cline { 2 - 5 } & Y & Médio & Baixa & Planejado \\
\cline { 2 - 5 } & Y & Alto & Baixa & Planejado \\
\cline { 2 - 5 } & Z & Médio & Altado & Validação \\
\cline { 2 - 5 } & Y & Baixo & Média & Validação \\
\cline { 2 - 5 } & Z & Alto & Baixa & Validação \\
\cline { 2 - 5 } & Y & Médio & Média & Simulação \\
\cline { 2 - 5 } & X & Alto & Alta & Baixo \\
\cline { 2 - 5 }
\end{tabular}

Modelo de camiseta: X: Sem estampas; Y: Possui o símbolo de uma famosa causa social estampado na frente; Z: Possui o símbolo de uma marca de roupas, que faz muitos comerciais na TV, estampado na frente.

Para o processamento da análise conjunta, utilizou-se uma sintaxe do programa estatístico SPSS 9.0, na qual as classificações das doze camisetas foram utilizadas como dados de entrada, sendo designados como dados ordenados (rank). Quanto ao relacionamento dos níveis dos fatores, nenhuma suposição foi feita sobre a preferência pelos tipos de marca. Já no que tange à variável qualidade, assumiu-se que níveis maiores são preferidos em relação aos menores; tendência essa oposta ao que foi adotado para o fator preço, visto que, nesse caso, níveis menores devem ser esperados como os preferidos.

Por fim, embora tenha requisitos conceituais, a execução da análise conjunta possui baixas exigências estatísticas; assim, testes de normalidade, homocedasticidade e independência das variáveis, que são realizados em outros métodos multivariados, não são necessários nessa técnica e, desse modo, não foram realizados com as variáveis estudadas. 


\subsubsection{Análise de conglomerados}

A análise de conglomerados é uma técnica estatística multivariada que permite a segmentação de um mercado ao combinar os objetos, ou as unidades observadas, para se formarem novos grupos com homogeneidade interna e heterogêneos externamente. (AAKER; KUMAR; DAY, 1995; HAIR JR. et al., 2006; LAMBIN, 2000).

Ela corresponde também a um importante método que pode ser exploratório ou confirmatório e que busca identificar uma estrutura de agrupamentos naturais para avaliar a dimensionalidade dos dados, encontrar outliers e fornecer hipóteses acerca do relacionamento das variáveis (HAIR JR. et al., 2006; JOHNSON; WICHERN, 1992).

Para a realização dessa análise utilizaram-se como variáveis de agrupamento os valores de utilidade dos tipos de marca e dos fatores qualidade e preço, todos obtidos da equação de preferência gerada para cada respondente após a execução da análise conjunta. $\mathrm{O}$ uso desse tipo de dado encontra fundamento em escritos de Furrier (2008b), Hair Jr. et al.(2006) e Lambin (2000) e atende a exigência da técnica de que as variáveis processadas caracterizem a opinião dos participantes que estão sendo agrupados. Devido ao modo como o relacionamento dos níveis de cada fator foi estabelecido, obtiveram-se cinco medidas de utilidade (uma para cada tipo de marca, uma para o fator qualidade e mais outra para o preço).

O programa utilizado para a execução da análise de dados foi o SPSS 9.0. A primeira etapa do processo foi a realização do agrupamento hierárquico, a fim de se avaliar a quantidade de grupos que poderiam ser formados. Para evitar impactos negativos na análise decorrentes de diferenças nas escalas das variáveis, elas foram padronizadas por meio da conversão em valores Z.

Nesta etapa, visto que a natureza dos dados de entrada era métrica, a similaridade entre os casos, a qual é o grau de correspondência entre os objetos através de todas as características consideradas na técnica, foi calculada por meio da medida de distância quadrática euclidiana. O algoritmo de agrupamento - que estabelece como a similaridade será definida entre os membros dos grupos durante o processo de aglomeração - utilizado foi average linkage, no qual a semelhança entre dois conglomerados é a similaridade média de todos os indivíduos em um grupo com todos os membros em outro, o que reduz a dependência do algoritmo em relação a valores extremos, como ocorre nos métodos nearest neighbor e complete linkage, tornando-o menos afetado por outliers e, também, tende a gerar grupos com variação interna menor e aproximadamente igual entre si (HAIR JR. et al., 2006). 
Como não havia nenhuma quantidade de grupos pré-estabelecida e fundamentada nos trabalhos consultados, este número foi escolhido quando o coeficiente de variância (ou heterogeneidade) de uma solução para a seguinte mais compacta apresentou um grande aumento, optando-se, desse modo, pela solução anterior, a fim de evitar uma forte redução da semelhança interna nos grupos (HAIR JR. et al., 2006).

Em um segundo momento, realizou-se o agrupamento não-hierárquico - o qual aloca as observações entre uma quantidade de grupos pré-determinada - a fim de aperfeiçoar o resultado obtido na etapa anterior por meio da melhor distribuição dos casos entre os grupos. Essa combinação de procedimentos permite que as vantagens do método hierárquico sejam complementadas pela habilidade do agrupamento não-hierárquico de refinar os resultados (HAIR JR. et al., 2006).

As variáveis de agrupamento dos respondentes utilizadas na aglomeração nãohierárquica foram as mesmas do método hierárquico, incluindo a padronização por meio da conversão em valores Z. A variável de identificação dos casos foi o número do grupo a que cada um foi associado (cluster membership) na alternativa escolhida entre as respostas do método hierárquico. O algoritmo utilizado no processamento não-hierárquico foi o nearest centroid sorting. Como centróides iniciais, utilizaram-se as médias aritméticas dos valores $\mathrm{Z}$ de cada variável em cada agrupamento da alternativa escolhida no processamento do método hierárquico. E, para obtenção da melhor divisão dos respondentes, optou-se que fosse realizada a iteração e a classificação, limitando-se a quantidade de tentativas em 100, sendo que o critério de convergência foi zero e a média móvel (running mean) foi adotada para as iterações.

Por fim, embora tenha requisitos conceituais, a execução da análise de conglomerados não possui requisitos de normalidade, linearidade e homocedasticidade; assim, os testes que verificam essas propriedades das variáveis não foram realizados em nenhum momento do processamento da técnica.

\subsubsection{Análise de elasticidade-preço da demanda}

A elasticidade, de acordo com Mankiw (2001, p. 94), “é a medida da resposta da quantidade demandada ou da quantidade oferecida às variações em seus determinantes”. Uma das variantes dessa medida é a elasticidade-preço da demanda, a qual mede a sensibilidade dos compradores ao preço por intermédio da intensidade da resposta da quantidade demandada a alterações no preço do bem, sendo calculada como variação percentual da quantidade demandada dividida pela variação percentual do preço (LAMBIN, 2000; MANKIW, 2001). 
Quando a elasticidade-preço da demanda é superior a 1 em magnitude, tem-se que a demanda de uma oferta é elástica ao preço, porque o percentual de redução da quantidade demandada é maior que o de aumento do preço; assim, um aumento de preços reduz a receita total e uma queda nos preços eleva a receita total (MANKIW, 2001; PINDYCK; RUBINFELD, 2002). Em casos extremos, chamados de demanda infinitamente elástica, os consumidores vão adquirir uma determinada quantidade a um dado preço e, de acordo com Pindyck e Rubinfeld (2002, p. 32), "no caso de um ínfimo aumento de preço acima desse nível, a quantidade demandada cai à zero; da mesma maneira, para quaisquer reduções no preço, a quantidade demandada aumenta de forma ilimitada”.

Já, se a elasticidade-preço da demanda é inferior a 1 em magnitude, diz-se que a demanda de uma oferta é inelástica ao preço, de modo que o percentual de redução da quantidade comercializada é menor do que o de aumento do preço; assim, um aumento de preços aumenta a receita total e uma queda de preços a reduz (MANKIW, 2001; PINDYCK; RUBINFELD, 2002). O caso extremo da inelasticidade ocorre quando os consumidores adquirirão uma quantidade fixa, não importando o nível de preço (PINDYCK; RUBINFELD, 2002).

E, quando a elasticidade-preço da demanda é exatamente igual a 1, diz-se que a demanda de uma oferta possui elasticidade unitária ao preço, visto que o aumento de preço é compensado exatamente na mesma proporção de queda da demanda; assim, uma variação no preço não afeta a receita total da empresa (MANKIW, 2001).

Em geral, a elasticidade-preço da demanda por uma oferta tende a variar em algumas situações devido a fatores externos a essas duas variáveis. Ela tende a aumentar conforme a disponibilidade de ofertas substitutas cresça, pois um aumento no preço de uma oferta faz com que o consumidor passe a comprar menos dela e mais de uma substituta (MANKIW, 2001; PINDYCK; RUBINFELD, 2002). Também, se uma oferta possui seu consumo considerado como necessário, ela passa a ter demanda menos elástica (MANKIW, 2001).

De acordo com Mankiw (2001, p. 94-95),

mercados definidos de forma restrita tendem a ter uma demanda mais elástica do que mercados definidos de forma ampla, uma vez que é mais fácil encontrar substitutos próximos para bens definidos de forma restrita. Por exemplo, comida, uma categoria ampla, tem uma demanda bastante inelástica [...]. Sorvete, uma categoria restrita, tem uma demanda mais elástica porque é fácil substituir sorvete por outras sobremesas.

As ofertas tendem a ter uma demanda mais elástica no longo prazo do que no curto, pois as pessoas demoram a modificar seus hábitos de consumo e a demanda por uma oferta 
pode estar ligada ao estoque de outra, a qual muda lentamente (MANKIW, 2001; PINDYCK; RUBINFELD, 2002).

O conhecimento da grandeza da elasticidade-preço da demanda é útil porque permite compará-la entre os tipos de marcas concorrentes a fim de se identificarem as que resistem melhor ao aumento de preço, ou seja, as que possuem maior fidelidade dos consumidores e, desse modo, prever os deslocamentos da procura de uma marca relativamente à outra, permitindo agir sobre os preços para estimular a procura e aumentar o volume de vendas (LAMBIN, 2000).

Nesse estudo, a elasticidade-preço da demanda foi calculada para os diferentes tipos de marca com base nas respostas obtidas para as questões seis e sete do instrumento de coleta de dados, sendo que a primeira perguntava sobre o quanto a pessoa pagaria por uma determinada camiseta conforme o seu tipo de marca e a segunda questionava sobre o quanto deveria custar essa mesma camiseta para cada tipo de marca a fim de que ela levasse mais outra igual, mas de cor diferente.

Geralmente, a elasticidade-preço da demanda é calculada como a variação percentual da quantidade demandada dividida pela variação percentual do preço; porém, a fim de garantir o mesmo valor de elasticidade no caso de um aumento ou redução de preço, adotouse para o seu cálculo o método do ponto médio (MANKIW, 2001). Para verificar se as elasticidades obtidas para cada tipo de marca são estatisticamente diferentes, realizou-se o teste t para amostras relacionadas, o qual é um teste de médias paramétrico descrito a seguir.

\subsubsection{Teste t para amostras relacionadas}

O teste $\mathrm{t}$ para amostras relacionadas é uma técnica paramétrica para avaliar a significância estatística da diferença entre as médias de duas amostras dependentes de uma variável, por exemplo, avaliações dos entrevistados sobre dois produtos (COOPER; SCHINDLER, 2003; HAIR JR. et al., 2006).

Essa técnica é aplicada aos escores-diferença, os quais podem ser obtidos a partir dos dois valores de cada sujeito submetido às duas condições, e estabelece como hipótese nula o fato de que não há diferença entre as médias das duas situações analisadas (ANDERSON et al., 2008; COOPER; SCHINDLER, 2003; SIEGEL; CASTELLAN JR., 2006).

O teste $t$ assume que os escores-diferença são extraídos de uma distribuição normal, o que implica que as variáveis são medidas pelo menos em uma escala intervalar; porém, quando o número de observações analisadas é maior do que 30, aproxima-se a distribuição 
delas à normal, mesmo elas não possuindo essa característica (ANDERSON et al., 2008; SIEGEL; CASTELLAN JR., 2006).

Neste estudo, o teste t foi utilizado para avaliar se havia diferença estatística entre as elasticidades-preço da demanda dos tipos de marca, a fim de se observar estatisticamente se um tipo de marca consegue desfrutar de maior fidelidade dos respondentes. Também, processou-se essa técnica com os preços atribuídos a cada tipo de camiseta apresentado na questão seis do instrumento de coleta de dados, com o objetivo de medir estatisticamente se um tipo de marca consegue desfrutar de um preço diferencial em relação aos demais.

Como os preços dos três tipos de camiseta foram atribuídos por todos os respondentes, esses dados e a elasticidade calculada com base neles atendem a exigência da técnica de dependência, ou relacionamento, das amostras analisadas. E, visto que a quantidade de respostas avaliadas é maior do que 30, desconsidera-se a necessidade de distribuição normal delas e, desse modo, satisfaz-se outro requisito do teste t. Finalmente, para a realização desse teste, utilizou-se o programa estatístico SPSS 9.0 e o nível de erro foi fixado em 1,67\%, pois, como foram realizadas, de modo separado, três comparações de média para cada grupo avaliado, utilizou-se a abordagem da desigualdade de Bonferroni para ajustar o nível de erro, a qual, de acordo com Hair Jr. et al.(2006), consiste em dividir o valor alfa proposto, que nesse estudo é $5 \%$, pelo número de testes estatísticos realizados, ou seja, três, resultando em um grau de significância mais exigente. 


\section{RESULTADOS}

\subsection{Características da amostra}

Foram obtidas 260 respostas; porém, a amostra efetivamente utilizada neste estudo é composta de 248 pessoas. Das 12 remoções, três foram por falta de informação em alguma das questões, exceto a pergunta quatro, a qual possuía preenchimento não obrigatório. As outras nove exclusões ocorreram por inconsistência entre as respostas nas questões seis e sete, visto que, ao ser obrigado a comprar, no mesmo momento, duas camisetas do mesmo tipo e que possuíam diferença somente na cor, esperava-se que o respondente oferecesse um preço unitário menor ou igual ao oferecido na situação em que se avaliava a compra de apenas uma camiseta de cada tipo; assim, pessoas que estabeleceram, na questão sete, preços unitários, para qualquer uma das camisetas, maiores do que os determinados na seis, foram excluídos.

Como exibido no gráfico 1, 126 participantes eram mulheres (51\% da amostra) e 122 eram homens (49\% dos entrevistados), o que demonstra um equilíbrio na distribuição entre os gêneros sexuais e confere a ambos o mesmo peso nos resultados da amostra.

\section{Gráfico 1: Distribuição da amostra por gênero sexual}

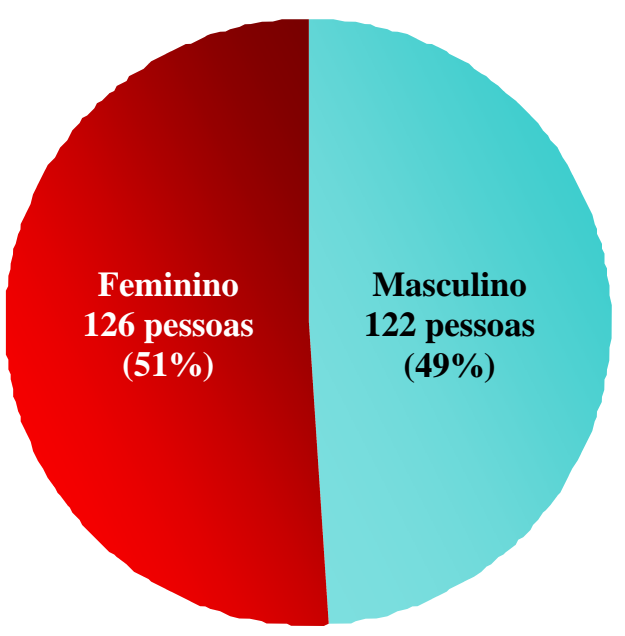

Quanto à distribuição etária, apresentada no gráfico 2, percebe-se que 80\% da amostra (198 pessoas) encontra-se entre 18 e 35 anos, sendo que 53\% possui idade entre 18 e 26 anos (131 respondentes). As idades com maior representatividade são 19 e 26 anos (23 e 22 casos, respectivamente), ambas com aproximadamente $9 \%$ da amostra, e o valor máximo encontrado na distribuição foi 65 anos. 
A distribuição etária da amostra não é normal, pois o seu valor $Z_{\text {curtose }}$ é igual a 3,72 e o $\mathrm{Z}_{\text {assimetria }}$ é 8,03, que indicam que, ao nível de erro de 5\%, rejeita-se a hipótese nula, a qual afirma que a variável possui distribuição normal. A mesma conclusão é obtida por meio do teste Kolmogorov-Smirnov, cuja significância foi menor do que 5\%.

\section{Gráfico 2: Distribuição da amostra por idade}

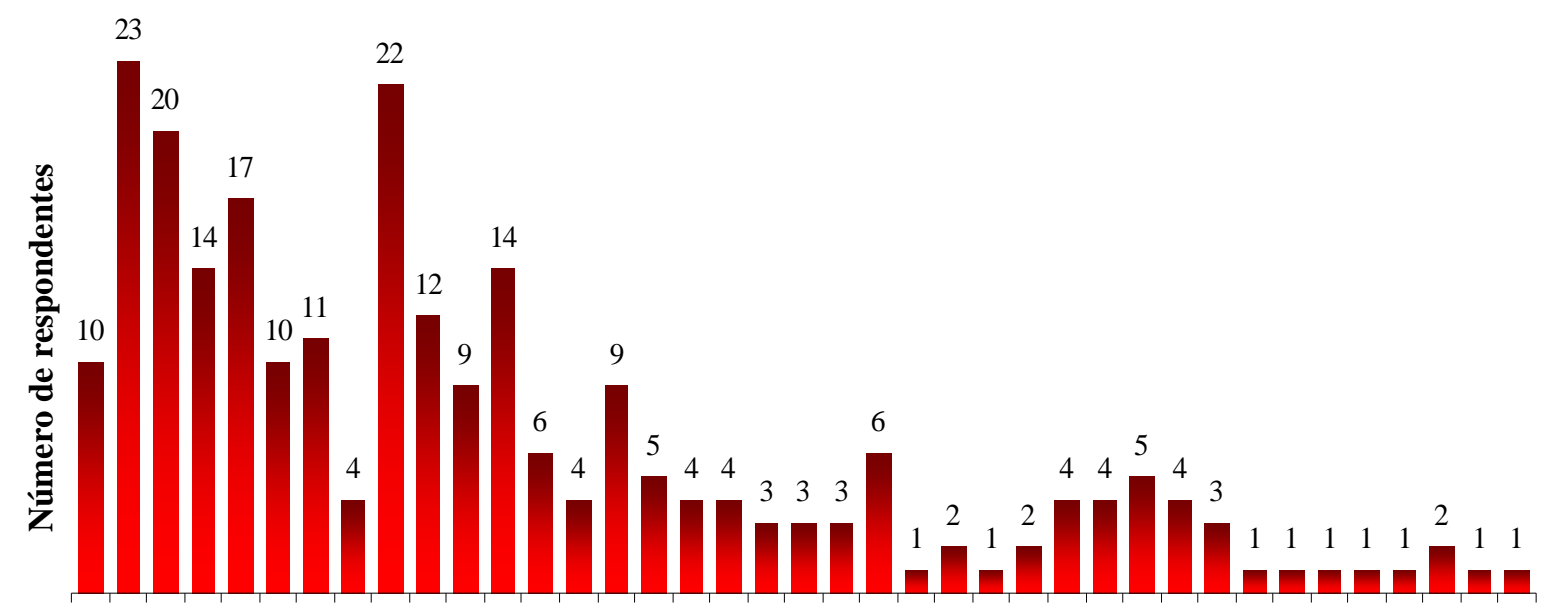

181920212223242526272829303132333435363738394041424344454647484950535455586165

Em relação ao grau de instrução, 99\% da amostra está concentrada nos níveis pósgraduação, superior completo e superior incompleto (109, 46 e 90 pessoas, respectivamente), conforme mostrado no gráfico 3, o que resulta em baixa representatividade de alguns grupos da população brasileira, como os que possuem somente o primeiro ou segundo grau completo, podendo, desse modo, haver algum viés nos resultados devido à baixa diversidade dos respondentes quanto ao grau de instrução. O principal motivo da concentração da amostra em três níveis de instrução foi a forma de coleta de dados adotada, visto que se focou na divulgação do questionário por meio de secretarias de cursos de pós-graduação e na sua aplicação em uma disciplina ministrada em um curso de graduação.

Contudo, a opinião de pessoas com menor grau de instrução não atenderia plenamente os objetivos deste estudo, visto que há indícios de que pessoas com baixo nível de escolaridade possuem menor grau de consciência de marcas (FURRIER, 2008). Desse modo, a fragilidade oriunda da concentração dos respondentes em altos níveis de instrução acaba não sendo tão grande. 


\section{Gráfico 3: Distribuição da amostra por grau de instrução}

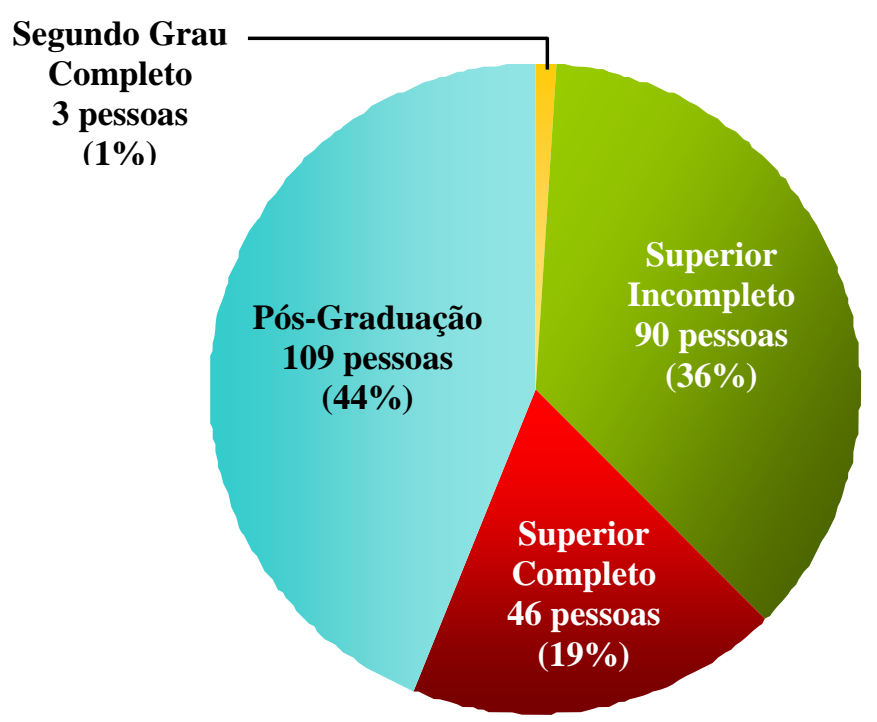

Gráfico 4: Distribuição da amostra por renda familiar mensal

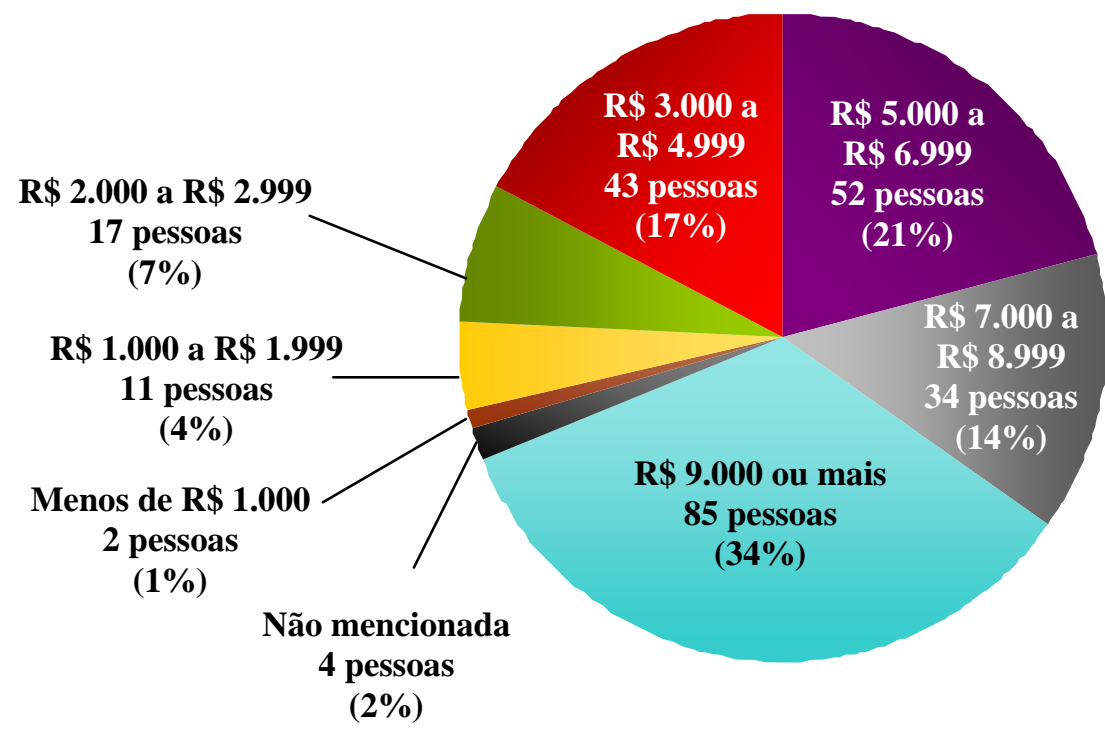

Observando-se a divisão dos respondentes segundo a renda familiar mensal, apresentada no gráfico 4, percebe-se uma melhor distribuição dos respondentes entre as faixas de renda estabelecidas; porém, ainda assim há uma concentração de quase $70 \%$ da amostra (171 casos) em respondentes com renda familiar mensal maior ou igual a R\$ 5000 (entre os homens, essa concentração é ainda maior, 76\%), o que, novamente, abre espaço para um possível viés devido à falta da opinião de pessoas de faixas de renda familiar menores, e é decorrente do modo como se executou a coleta de dados, visto que, normalmente, pessoas que 
frequentam ou finalizaram a pós-graduação, normalmente, possuem alta renda familiar, devido à maior instrução educacional.

Entretanto, uma grande presença de respondentes de níveis de baixa renda familiar mensal não era muito interessante para os objetivos desse trabalho, pois, devido ao baixo poder aquisitivo, as pessoas pertencentes a eles acabam tendo pequeno poder de escolha entre as marcas disponíveis. Como já comentado, há indícios de que as classes econômicas mais baixas possuem menor grau de consciência de marcas, devido à menor instrução e limitação de consumo decorrente da baixa renda (FURRIER, 2008).

Tendo sido optativo o fornecimento da informação da renda familiar mensal, quatro pessoas não a mencionaram.

Em relação à preferência expressa pela amostra aos tipos de marcas, exibida no gráfico 5, observa-se que a camiseta mais barata é a preferida pelas pessoas (38\% dos respondentes), sendo essa a descrição associada à marca genérica, a qual compete no mercado pela melhor relação custo-benefício. E, entre o grupo de respondentes do sexo masculino, essa preferência é ainda maior, 43\%, versus o segundo tipo de marca mais escolhido, a de fabricante, que possuía 33\% das respostas desse grupo.

\section{Gráfico 5: Distribuição da amostra por tipo de camiseta preferido}

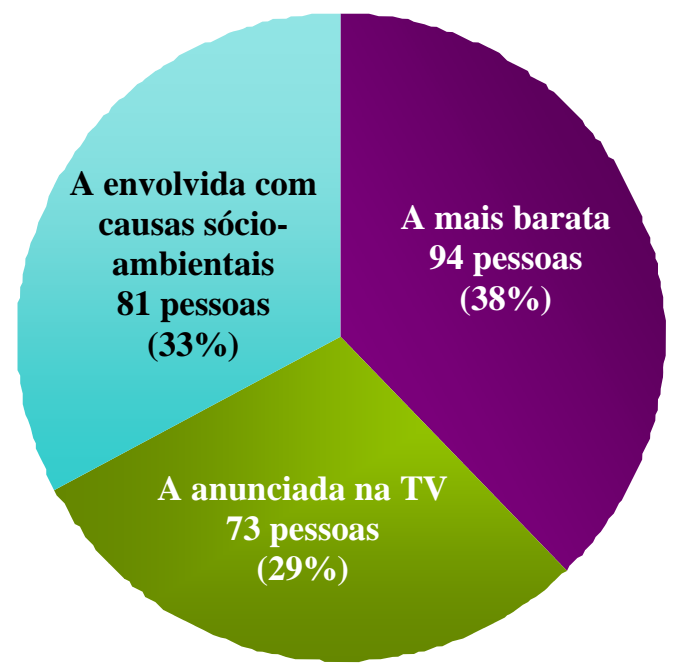

Contudo, a camiseta cuja comercialização possui envolvimento, direto ou indireto, com uma causa social e/ou ambiental teve aceitação de 33\% da amostra, a qual pode ser considerada alta, sendo esse número muito próximo da preferência de $37 \%$ citada por Produtos (2008). Constatou-se, também, que das 81 pessoas que escolheram a marca social, 
51 eram mulheres. Analisando-se somente os respondentes do sexo feminino, a preferência pela camiseta social salta para $40 \%$, a qual é seguida pela marca genérica, que conta apenas com 31\% da preferência das mulheres. Esses dados demonstram que a marca social possui uma maior aceitação entre o público feminino, semelhante ao que foi encontrado em estudo da Letshal, o qual apontava, de acordo com Magalhães (2011), que 51\% das mulheres se preocupam mais em ajudar os outros.

Ao serem solicitados para ordenarem, de acordo com a importância para a decisão de compra, quatro atributos de camisetas estudados, observou-se, conforme tabela 1, que a qualidade é, com grande vantagem, o primeiro fator em termos de importância (principal atributo para 169 pessoas, ou seja, 68\% da amostra válida) e preço é o segundo atributo mais importante para 58\% dos respondentes (144 casos). Já a marca e o envolvimento dela com uma causa sócio-ambiental são os fatores menos importantes para a amostra.

Tabela 1: Distribuição da opinião de importância dos atributos de uma camiseta

\begin{tabular}{|c|c|c|c|c|}
\cline { 2 - 5 } \multicolumn{1}{c|}{} & Preço & Marca & Qualidade & Envolvimento sócio-ambiental \\
\hline Primeiro atributo & 43 & 25 & 169 & 11 \\
\hline Segundo atributo & 144 & 33 & 50 & 21 \\
\hline Terceiro atributo & 54 & 79 & 26 & 89 \\
\hline Quarto atributo & 7 & 111 & 3 & 127 \\
\hline
\end{tabular}

A leitura da tabela 1 em conjunto com o gráfico 5 mostra que primeiramente uma marca precisa aplicar um preço considerado justo e transmitir a percepção de qualidade, a fim de entrar no grupo de consideração do consumidor, para somente então diferenciar-se dos concorrentes e ser escolhida por meio dos seus significados e envolvimento com causas sociais e/ou ambientais. E, há um grupo de respondentes que ainda é subdesenvolvido em termos de consumo dos significados da marca, preferindo produtos que tragam benefícios tangíveis, principalmente, preço baixo.

Portanto, a amostra desse estudo é bem dividida entre ambos os gêneros sexuais, possui concentração etária entre 18 e 35 anos, alto grau de instrução, alta renda familiar mensal, têm maior preferência declarada pelas camisetas mais baratas e a qualidade e o preço são os atributos citados como os mais importantes na decisão de compra desse produto.

\subsection{Análise da importância dos atributos na preferência de compra}

A análise conjunta das opiniões de preferência de compra da amostra em relação às doze camisetas testadas forneceu um modelo ajustado aos dados, cuja correlação de postos de 
Kendall era 0,817, mas com baixa validade interna, sendo que a correlação de Kendall para o conjunto de validação (holdout) foi 0,333. Ademais, foram obtidos cinco casos com dois reversals - respostas em sentido contrário ao relacionamento dos níveis assumido para algum fator - e 42 com somente um reversal, sendo que relacionamento determinado para os níveis do fator qualidade foi responsável por 37 desses casos e o do atributo preço por 15 deles. A tabela 2 reúne essas medidas de qualidade do modelo.

Tabela 2: Medidas de qualidade do modelo de preferência da amostra

\begin{tabular}{|c|c|c|c|c|c|}
\hline \multicolumn{2}{|c|}{ Correlação de Kendall } & \multicolumn{3}{|c|}{ Quantidade de casos com reversals } \\
\cline { 3 - 6 } & & \multicolumn{2}{|c|}{ Por quantidade } & \multicolumn{2}{c|}{ Por fatores } \\
\hline Modelo & Validação & 1 reversal & 2 reversals & Qualidade & Preço \\
\hline 0,817 & 0,333 & 42 & 5 & 37 & 15 \\
\hline
\end{tabular}

A fim de melhorar a qualidade do modelo de preferência gerado para a amostra, procedeu-se com a remoção de alguns casos. Primeiramente, retiraram-se os 47 casos com reversals. Optou-se por iniciar com a remoção desses casos, sem avaliar o coeficiente de correlação de Kendall de cada um deles com o modelo, pois, como somente dois fatores possuíam tendência definida, o número máximo de reversals que poderia ocorrer eram dois; assim, a ocorrência de somente um já seria o suficiente para reduzir a contribuição do caso para o modelo de preferência gerado pela análise conjunta, visto que um terço dos fatores estaria comprometido para o caso. Ademais, uma ordem de preferência contrária à pressuposta aos fatores preço e qualidade não possui sentido prático, visto que significaria que o respondente prefere qualidade baixa ao invés de alta, ou o contrário no caso do fator preço.

Como nenhuma melhora ocorreu na correlação de Kendall para o conjunto de validação, após essa primeira etapa de retiradas, procedeu-se com a remoção dos casos que não possuíam reversals, mas que tivessem o módulo da correlação de validação menor ou igual a 0,333 e da correlação da modelagem abaixo de 0,7. A ordem de exclusão desses casos foi do menor módulo de correlação de Kendall do modelo ao mais próximo do valor 0,7, sendo que, após a exclusão de cada caso, era avaliada a possível melhora dos indicadores de qualidade do modelo antes da próxima retirada. Para melhoria dos indicadores de qualidade do modelo, foram necessárias mais 17 exclusões, totalizando 64 casos retirados de uma amostra de 248, conforme apresentado na tabela 3.

O modelo de preferência de compra da amostra gerado após as exclusões apresentou melhor ajuste aos dados - correlação de postos de Kendall 0,833 - e validade interna, sendo que a correlação de Kendall para o conjunto de validação (holdout) passou para 0,816; desse 
modo, esse é o modelo adotado para descrever a preferência de compra de camisetas pela amostra. Devido aos critérios de exclusão adotados, o número de reversals foi zero.

Tabela 3: Casos excluídos para melhoria do modelo de preferência da amostra

\begin{tabular}{|c|c|c|c|}
\hline Código do Caso & $\begin{array}{c}\text { Correlação de Kendall } \\
\text { do modelo }\end{array}$ & $\begin{array}{c}\text { Correlação de Kendall } \\
\text { da validação }\end{array}$ & Quantidade de reversals \\
\hline 7 & 0,333 & 0,333 & - \\
\hline 12 & 0,817 & 1,000 & 1 \\
\hline 20 & 0,514 & 0,816 & 1 \\
\hline 27 & 1,000 & 1,000 & 1 \\
\hline 31 & 0,629 & 0,333 & - \\
\hline 35 & 0,592 & 0,333 & - \\
\hline 36 & 0,667 & 0,333 & - \\
\hline 37 & 0,667 & $-0,333$ & 1 \\
\hline 39 & 0,833 & 1,000 & 1 \\
\hline 51 & 0,500 & 0,333 & 1 \\
\hline 53 & 0,254 & $-0,333$ & 2 \\
\hline 55 & 0,667 & 1,000 & 1 \\
\hline 65 & 0,648 & 0,333 & 1 \\
\hline 66 & 0,629 & $-0,333$ & - \\
\hline 70 & 0,611 & 0,333 & - \\
\hline 72 & 0,535 & 0,333 & - \\
\hline 76 & 0,278 & $-0,333$ & 2 \\
\hline 82 & 0,500 & 0,333 & - \\
\hline 83 & 0,743 & 1,000 & 1 \\
\hline 87 & 0,167 & 0,333 & 1 \\
\hline 91 & 0,648 & 0,333 & - \\
\hline 100 & 0,629 & $-0,333$ & - \\
\hline 101 & 0,889 & 1,000 & 2 \\
\hline 113 & 0,629 & $-0,333$ & - \\
\hline 121 & 0,833 & $-0,333$ & 1 \\
\hline 126 & 0,889 & 1,000 & 1 \\
\hline 140 & 0,889 & 1,000 & 1 \\
\hline 145 & 0,535 & 0,333 & 1 \\
\hline 146 & 0,548 & 0,816 & 1 \\
\hline 148 & 0,889 & 0,333 & 1 \\
\hline 153 & 0,377 & $-1,000$ & 1 \\
\hline 154 & 0,366 & $-0,333$ & 1 \\
\hline 159 & 0,611 & 0,333 & 1 \\
\hline 165 & 0,667 & 0,333 & - \\
\hline 166 & 0,889 & 1,000 & 2 \\
\hline 167 & 0,556 & $-0,333$ & - \\
\hline 168 & 0,913 & 0,333 & 1 \\
\hline 169 & 0,889 & 1,000 & 2 \\
\hline 184 & 1,000 & 1,000 & 1 \\
\hline 186 & 0,817 & 1,000 & 1 \\
\hline 187 & 0,761 & 0,333 & 1 \\
\hline 190 & 0,833 & 0,333 & 1 \\
\hline 192 & 0,833 & $-0,333$ & 1 \\
\hline 194 & 0,261 & 0,333 & 1 \\
\hline 196 & 0,778 & 0,333 & 1 \\
\hline 200 & 1,000 & 1,000 & 1 \\
\hline 201 & 0,444 & $-0,333$ & 1 \\
\hline 203 & 1,000 & 0,333 & 1 \\
\hline
\end{tabular}




\begin{tabular}{|c|c|c|c|}
\hline Código do Caso & $\begin{array}{c}\text { Correlação de Kendall } \\
\text { do modelo }\end{array}$ & $\begin{array}{c}\text { Correlação de Kendall } \\
\text { da validação }\end{array}$ & Quantidade de reversals \\
\hline 205 & 0,778 & 0,816 & 1 \\
\hline 209 & 0,928 & $-0,333$ & 1 \\
\hline 210 & 0,944 & 1,000 & 1 \\
\hline 213 & 0,592 & 0,333 & 1 \\
\hline 215 & 0,667 & 0,333 & - \\
\hline 216 & 0,889 & 0,333 & 1 \\
\hline 217 & 0,686 & 0,333 & - \\
\hline 223 & 0,611 & 0,333 & - \\
\hline 224 & 0,389 & $-0,333$ & 1 \\
\hline 225 & 1,000 & 1,000 & 1 \\
\hline 226 & 0,857 & 0,333 & 1 \\
\hline 232 & 0,833 & 0,333 & - \\
\hline 234 & 0,889 & 1,000 & 1 \\
\hline 237 & 0,545 & 0,333 & 1 \\
\hline 247 & 0,778 & 0,333 & \\
\hline 248 & 0,889 & 1,000 & \\
\hline
\end{tabular}

Gráfico 6: Importância dos atributos da camiseta na preferência de compra da amostra

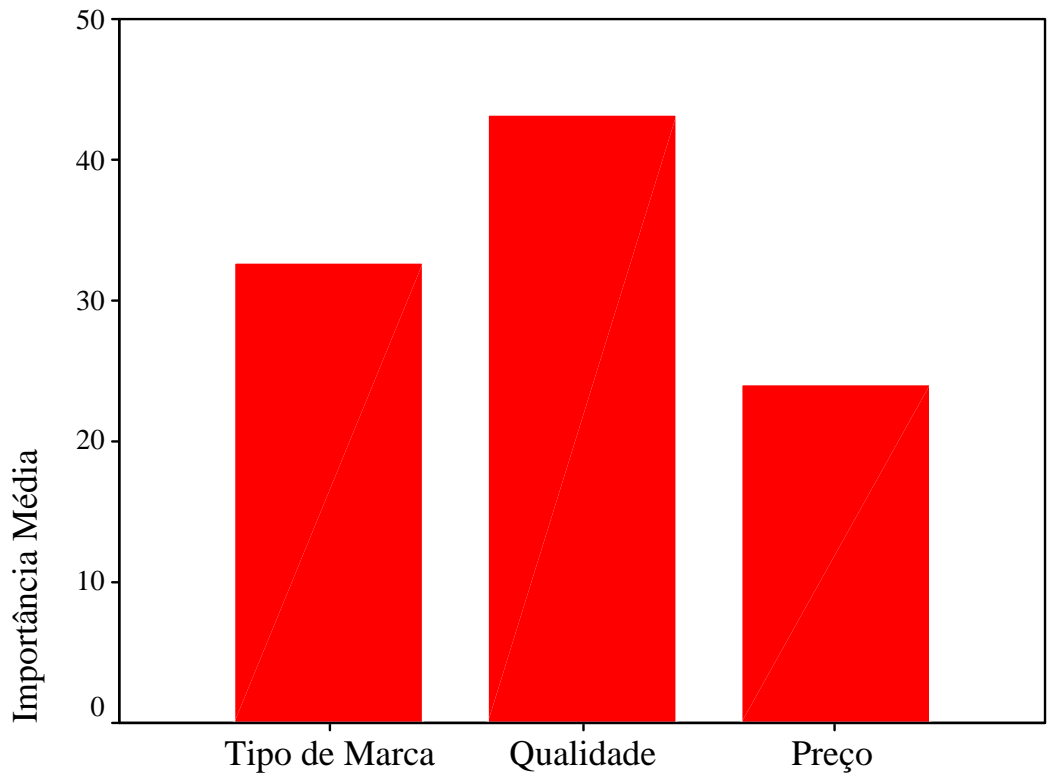

Atributo

Na opinião da amostra, a qualidade de uma camiseta é o atributo mais importante para o respondente (importância média de 43,3\%), sendo o tipo de marca (32,7\%) e o preço (24\%), respectivamente, o segundo e o terceiro em termos de relevância, como mostrado no gráfico 6. A sequência de preferência desses fatores é diferente do que havia sido constatado quando foi pedido para os respondentes ordenarem, segundo a importância em uma situação de compra de uma camiseta, esses três atributos mais o envolvimento com uma causa social e/ou 
ambiental, sendo que nesse caso, apesar de a qualidade ainda tenha sido citada como o principal, o preço havia obtido uma maior importância em relação à marca. Assim, embora a amostra não expresse quando questionada, inconscientemente a marca possui maior importância em relação ao preço na preferência dela por diferentes camisetas.

A maior importância da marca, em comparação ao preço, na preferência da amostra, revela um bom nível de desenvolvimento dos respondentes em termos de conscientização do consumo de significados da marca e opõe-se à idéia de que as pessoas escolhem produtos pelo preço, optando sempre pelo mais barato, independente da marca. Além disso, ao ser a qualidade o atributo de maior importância na preferência do respondente, conclui-se que uma marca deve, primeiramente, apresentar benefícios tangíveis, para somente depois diferenciarse por meio dos seus significados. O interessante é que a marca pode reforçar a percepção dessa qualidade e isso novamente enfatiza a importância da marca na opinião da amostra.

\section{Gráfico 7: Preferência da amostra pelos tipos de marca}

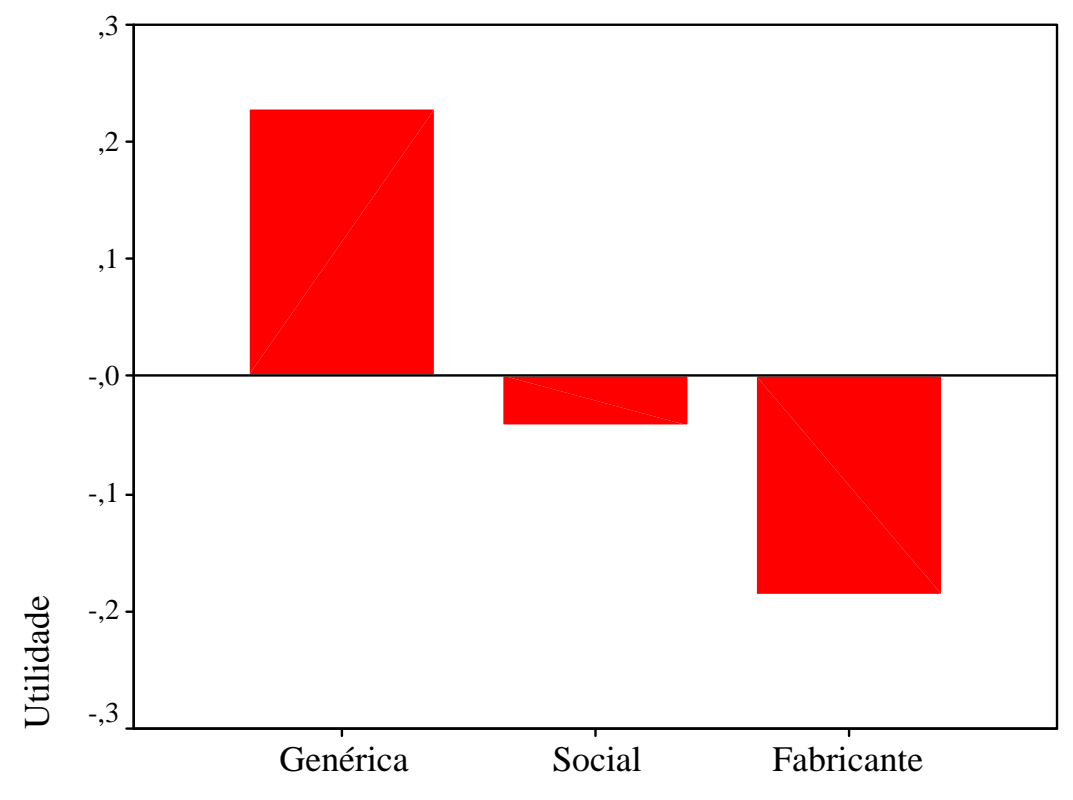

Tipo de Marca

Em relação aos tipos de marca, o gráfico 7 revela que a marca genérica é a preferida pela amostra (utilidade de 0,2283). A marca social e de fabricante possuem, respectivamente, utilidade de -0,0417 e -0,1866; assim, a amostra apresenta certa aversão a esses tipos de marca, sendo que o último deles tem um impacto negativo na preferência quase tão forte quanto a influência positiva da marca genérica. Essa ordem de preferência pelos tipos de marca é 
bastante coerente com a declaração explícita feita pelos respondentes durante a coleta de dados, quando 38\% deles disseram preferir a marca genérica, 33\% a social e $29 \%$ a de fabricante.

A maior preferência pela marca genérica demonstra que os respondentes preocupamse em não transmitir explicitamente os seus valores e idéias, o que ocorreria no caso de uma camiseta com uma marca de fabricante ou social, a qual comunicaria os significados associados à marca. Também, a maior escolha pelas marcas genéricas reduz a possibilidade de se criar fidelidade a elas, pois esse tipo de marca possui baixa ou nenhuma diferenciação, sendo apenas associada à boa relação qualidade-preço.

A estrutura de preferência da amostra pela qualidade apresentou, de acordo com o gráfico 8, uma maior utilidade ao nível alta $(-1,8351)$ e uma menor ao estado baixo $(-5,5054)$, sendo esse o movimento que havia sido pressuposto para o fator, visto que em uma relação comercial, é esperado que uma pessoa prefira a maior quantidade possível de benefícios (entre eles a qualidade) para cada unidade de recursos dados em troca. Nota-se, também, o grande impacto que a qualidade tem na utilidade de um produto $(B=-1,8351)$, sendo $77 \%$ maior do que o do fator preço ( $\mathrm{B}=1,0362$, como apresentado no gráfico 9).

\section{Gráfico 8: Preferência da amostra pelos níveis de qualidade}

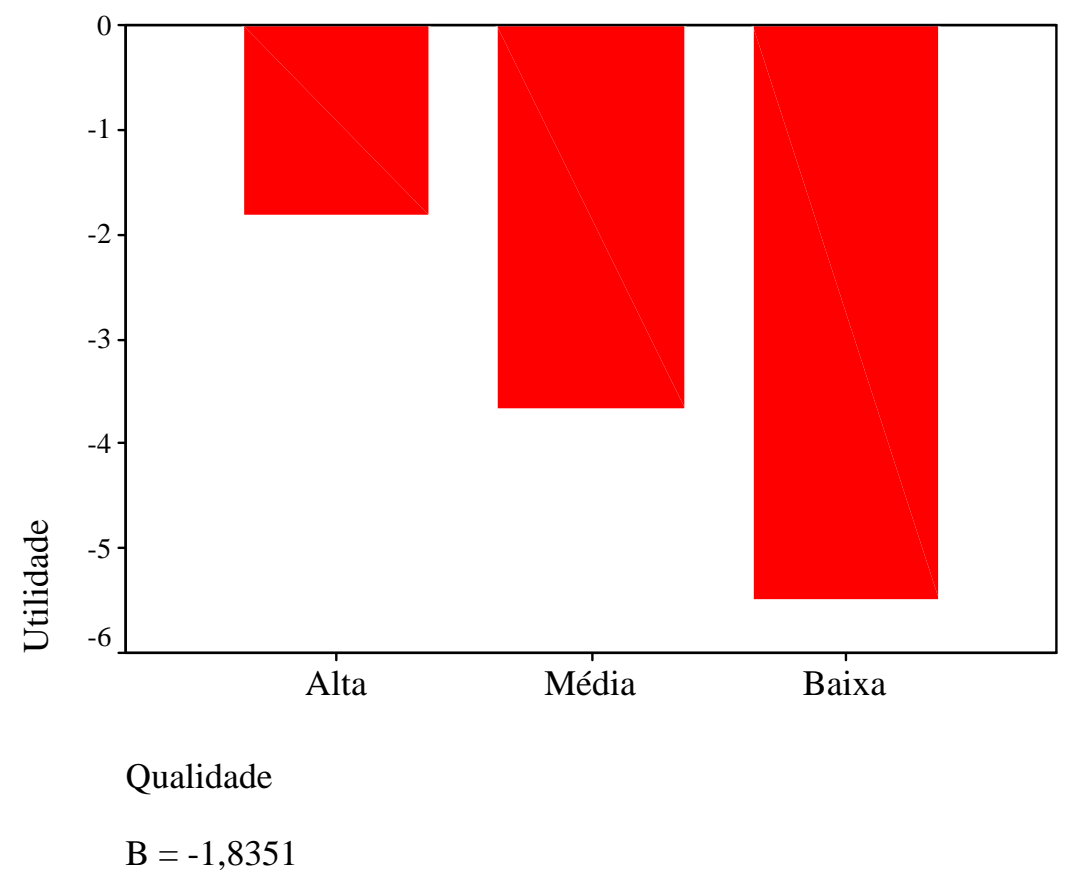

Quanto menor é o índice de utilidade de um nível, menor é a preferência por ele; contudo, ressalta-se que os valores negativos da utilidade das graduações do fator qualidade não ocorreram devido à aversão da amostra a elas, mas sim pelo modo como foram 
estabelecidas e processadas pela análise conjunta, pois, como os níveis alto, médio e baixo foram codificados, respectivamente, como 1, 2 e 3, e a relação entre eles foi estabelecida como linear decrescente (linear less), visto que se assumiu que níveis mais altos de qualidade são os preferidos, a estrutura de preferência do fator qualidade apresentou-se como negativa a fim de representar uma tendência decrescente conforme o código do nível aumenta.

As respostas em relação ao fator preço, mostradas no gráfico 9, deixam clara a preferência da amostra por camisetas com preços mais baixos, o que é coerente com a maior inclinação dela para as marcas genéricas, as quais possuem a estratégia de fornecer uma boa relação entre qualidade e preço, e com o pressuposto assumido para esse fator na execução da análise conjunta, o qual estabelecia que as pessoas preferem produtos com o menor preço em relação a similares de preço maior.

Gráfico 9: Preferência da amostra pelos níveis de preço

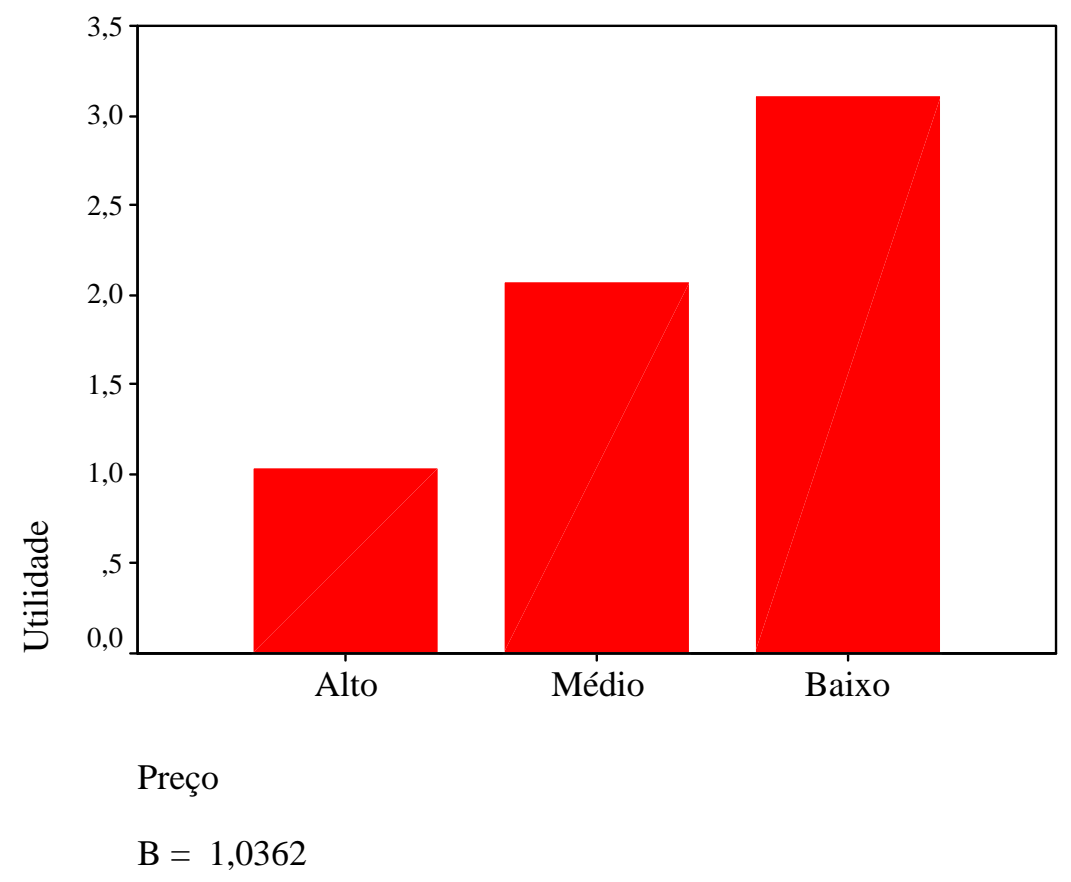

Portanto, de acordo com os resultados apresentados, para integrar a lista de consideração dos respondentes, a marca primeiro precisa reforçar a percepção de qualidade do produto, o principal fator de preferência por parte da amostra, para somente depois atuar como um elemento de diferenciação, restando ao preço o papel de critério de desempate no caso de não diferenciação entre duas ou mais marcas. Essa constatação é convergente com a afirmação de Steenkamp, Batra e Alden (2003) de que as marcas devem se focar em criar e 
comunicar qualidade ao invés de benefícios em termos de status e prestígio. E, o tipo de camiseta preferido pela amostra é o de marca genérica, que não exibe nenhum signo aparente, com alta qualidade e baixo preço, sendo essas duas últimas características coerentes com o tipo de marca preferido, pois as marcas genéricas concorrem por meio do oferecimento de produtos com a melhor qualidade a um determinado preço.

Por fim, para testar a capacidade de previsão do modelo de preferência da amostra, avaliou-se a escolha entre as duas camisetas criadas para simulação. A que possui marca social (modelo Y), preço baixo e qualidade alta é a predileta. Mesmo apresentando marca genérica, a qual é a preferida pelos respondentes, a outra opção não foi escolhida por muitos porque esse atributo não possui utilidade suficiente para compensar o menor nível de qualidade, que nesse caso é média, sendo que, para a amostra, a qualidade tem importância maior que o tipo de marca. A tabela 4 apresenta os percentuais de preferência de cada camiseta simulada segundo os métodos de previsão de escolha utilidade máxima, BTL e Logit.

Tabela 4: Preferência da amostra pelos dois estímulos de simulação

\begin{tabular}{|l|c|c|c|}
\hline \multicolumn{1}{|c|}{ Produto simulado } & Utilidade máxima & BTL & Logit \\
\hline Camiseta modelo X, preço baixo, qualidade média & $24,18 \%$ & $44,82 \%$ & $28,94 \%$ \\
\hline Camiseta modelo Y, preço baixo, qualidade alta & $75,82 \%$ & $55,18 \%$ & $71,06 \%$ \\
\hline
\end{tabular}

Modelo de camiseta: X: Sem estampas; Y: Possui o símbolo de uma famosa causa social estampado na frente.

\subsubsection{Análise da importância dos atributos na preferência de compra dos optantes pela marca genérica}

Possuindo a preferência expressa dos respondentes pelos tipos de marca, decidiu-se comparar se ela é realmente considerada no momento de escolha das camisetas. Primeiramente analisaram-se as pessoas que, ao escolherem a opção da camiseta mais barata na questão oito, foram consideradas como tendo declarado preferirem a marca genérica, grupo esse composto por 94 respondentes. Os parâmetros utilizados para a análise conjunta das opiniões desse grupo permaneceram iguais aos utilizados na da amostra total.

O modelo gerado para o grupo que declarou preferir a marca genérica apresentou um forte ajuste aos dados (coeficiente de correlação de Kendall igual a 0,889); porém, possuía baixa validade interna, apresentando um valor de correlação de Kendall para o conjunto de validação (holdout) de 0,333. E, dos 94 respondentes, três apresentaram dois reversals e 14 tiveram apenas um, sendo que o atributo preço foi responsável por 14 deles e a qualidade pelos outros seis reversals. A tabela 5 reúne essas medidas de qualidade do modelo. 
Tabela 5: Medidas de qualidade do modelo de preferência dos optantes pela marca genérica

\begin{tabular}{|c|c|c|c|c|c|}
\hline \multicolumn{2}{|c|}{ Correlação de Kendall } & \multicolumn{3}{|c|}{ Quantidade de casos com reversals } \\
\cline { 3 - 6 } & & \multicolumn{2}{|c|}{ Por quantidade } & \multicolumn{2}{c|}{ Por fatores } \\
\hline Modelo & Validação & 1 reversal & 2 reversals & Qualidade & Preço \\
\hline 0,889 & 0,333 & 14 & 3 & 6 & 14 \\
\hline
\end{tabular}

A fim de melhorar a qualidade do modelo de preferência gerado para o grupo que diz optar pela marca genérica, procedeu-se com a remoção de alguns casos. Igual ao feito no modelo gerado para a amostra total, primeiramente, retiraram-se os 17 casos com reversals. E, como nenhuma melhora ocorreu na correlação de Kendall para o conjunto de validação, após a exclusão desses 17 respondentes, procedeu-se com a remoção dos casos que não possuíam reversals, mas que tivessem o módulo da correlação de validação menor ou igual a 0,333 e da correlação da modelagem abaixo de 0,8.

Tabela 6: Casos excluídos para melhoria do modelo dos optantes pela marca genérica

\begin{tabular}{|c|c|c|c|}
\hline Código do Caso & $\begin{array}{c}\text { Correlação de Kendall } \\
\text { do modelo }\end{array}$ & $\begin{array}{c}\text { Correlação de Kendall } \\
\text { da validação }\end{array}$ & Quantidade de reversals \\
\hline 14 & 0,722 & 0,333 & - \\
\hline 20 & 0,514 & 0,816 & 1 \\
\hline 35 & 0,592 & 0,333 & - \\
\hline 39 & 0,833 & 1,000 & 1 \\
\hline 47 & 0,761 & 0,333 & - \\
\hline 51 & 0,500 & 0,333 & 1 \\
\hline 53 & 0,254 & $-0,333$ & 2 \\
\hline 55 & 0,667 & 1,000 & 1 \\
\hline 70 & 0,611 & 0,333 & - \\
\hline 76 & 0,278 & $-0,333$ & 2 \\
\hline 101 & 0,889 & 1,000 & 2 \\
\hline 119 & 0,778 & 0,333 & - \\
\hline 126 & 0,889 & 1,000 & 1 \\
\hline 133 & 0,704 & 0,333 & - \\
\hline 134 & 0,778 & 0,333 & - \\
\hline 145 & 0,535 & 0,333 & 1 \\
\hline 154 & 0,366 & $-0,333$ & 1 \\
\hline 165 & 0,667 & 0,333 & - \\
\hline 178 & 0,704 & 0,333 & - \\
\hline 186 & 0,817 & 1,000 & 1 \\
\hline 190 & 0,833 & 0,333 & 1 \\
\hline 192 & 0,833 & $-0,333$ & 1 \\
\hline 203 & 1,000 & 0,333 & 1 \\
\hline 207 & 0,722 & 0,333 & - \\
\hline 209 & 0,928 & $-0,333$ & 1 \\
\hline 216 & 0,889 & 0,333 & 1 \\
\hline 232 & 0,833 & 0,333 & 1 \\
\hline 237 & 0,545 & 0,333 & - \\
\hline
\end{tabular}


A ordem de exclusão desses casos foi do menor módulo de correlação de Kendall do modelo ao mais próximo do valor 0,8 , sendo que, após a exclusão de cada caso, era avaliada a possível melhora dos indicadores de qualidade do modelo antes da próxima retirada, o que resultou na manutenção de dois casos que possuíam correlação de Kendall do modelo e de validação igual a 0,778 e 0,333, respectivamente, enquanto outros dois que possuíam os mesmos valores foram excluídos. Para melhoria dos indicadores de qualidade do modelo, foram necessárias mais 11 exclusões, totalizando 28 casos retirados de uma amostra de 94, conforme apresentado na tabela 6.

O modelo de preferência de compra da amostra gerado após as exclusões apresentou uma pequena redução no ajuste aos dados, correlação de postos de Kendall do modelo reduziu-se de 0,889 para 0,833; porém, agora ele possui um bom grau de validade interna, visto que a correlação de Kendall para o conjunto de validação (holdout) passou para 0,816. Desse modo, esse é o modelo adotado para descrever a preferência de compra das pessoas que declararam optarem pelas camisetas com característica de marca genérica. Devido aos critérios de exclusão adotados, o número de reversals foi zero.

\section{Gráfico 10: Importância dos atributos da camiseta na preferência de compra dos optantes pela marca genérica}

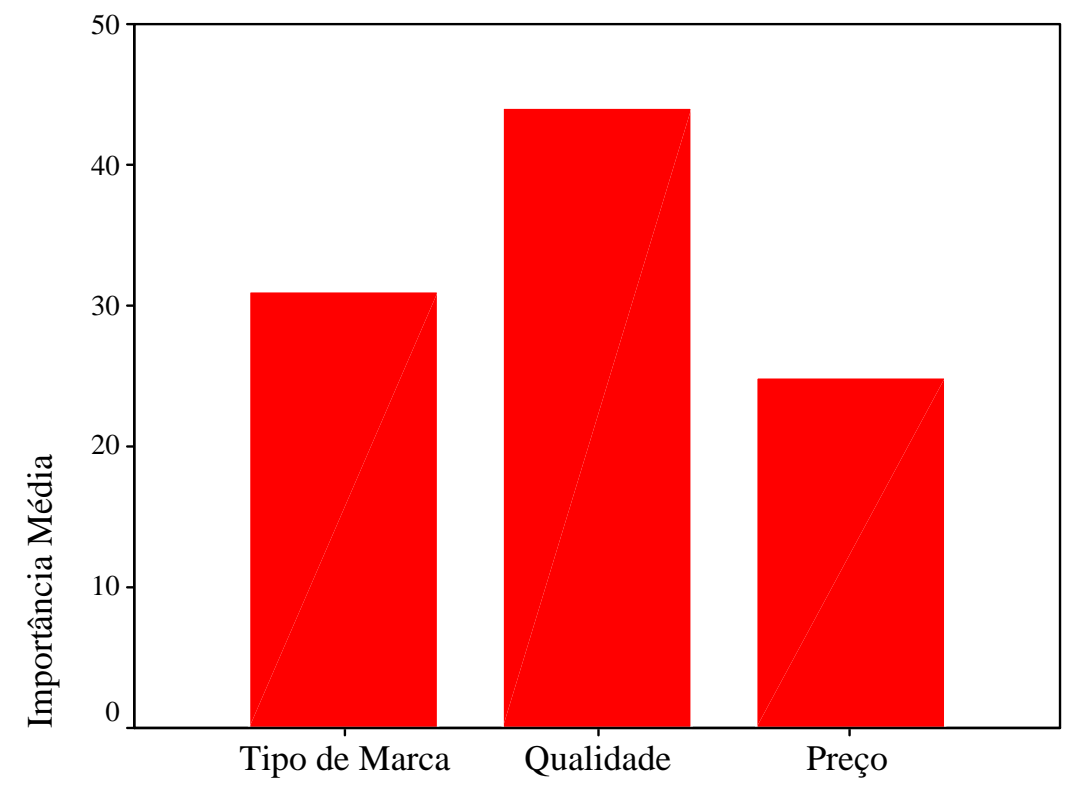

Atributo 
Na opinião do grupo que prefere a marca genérica, a qualidade de uma camiseta é o atributo principal (importância média de 44,12\%), sendo o tipo de marca (30,94\%) e o preço (24,94\%), respectivamente, o segundo e o terceiro em termos de relevância, como mostrado no gráfico 10. Pelo fato de esse grupo ter declarado que no momento de escolha prefere a camiseta mais barata, era esperado que pelo menos a ordem dos fatores preço e tipo de marca fosse diferente, pois havia a expectativa de que esses respondentes fossem mais preocupados com o preço do que com a marca do produto.

Em relação aos tipos de marca, conforme o gráfico 11, a marca genérica é a preferida por esse grupo (utilidade de 0,7727 ), sendo que a de fabricante vem em seguida com índice de utilidade de -0,3636, o que demonstra aversão dos respondentes a ela. A preferência pela marca genérica fornecida pelo modelo é maior do que a obtida para a amostra total e é coerente com a declarada pelo grupo em relação à camiseta mais barata, visto que o baixo preço, característica escolhida por esses respondentes, é comum a esse tipo de marca.

Essa predileção pela marca genérica demonstra que esse grupo preocupa-se em não transmitir explicitamente os seus valores e idéias por meio de signos estampados na camiseta. Ademais, em relação à amostra total, a maior aversão pela marca social (utilidade igual a -0,4091) e a maior importância da qualidade e preço demonstra que esse grupo é mais focado em benefícios para si, como produtos de melhor desempenho ou mais baratos.

\section{Gráfico 11: Preferência dos optantes pela marca genérica pelos tipos de marca}

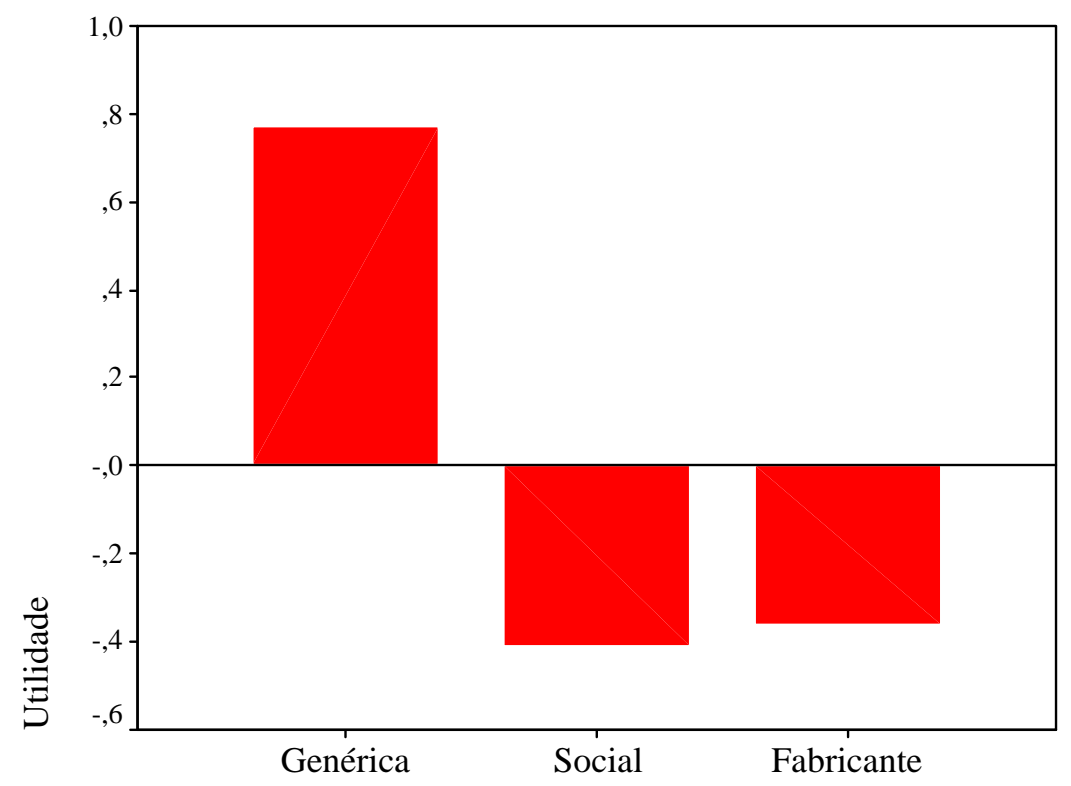

Tipo de Marca 
A estrutura de preferência, do grupo que escolheu a marca genérica, pela qualidade apresentou, de acordo com o gráfico 12, uma maior utilidade ao nível alta $(-1,8788)$ e uma menor ao estado baixo $(-5,6364)$, sendo esse o movimento que havia sido pressuposto para o fator. E, igual ao que havia ocorrido com a amostra total, há grande impacto da qualidade na utilidade de um produto ( $\mathrm{B}=-1,8788$ ), sendo, novamente, $77 \%$ maior do que o do fator preço ( $B=1,0606$, como verificado no gráfico 13). Ressalta-se que os valores negativos da utilidade dos níveis do fator qualidade não ocorreram devido à aversão da amostra a eles, mas sim pelo modo como foram estabelecidos e processados pela análise conjunta. Contudo, quanto mais negativo é o valor de um nível, menor é a preferência por ele.

Gráfico 12: Preferência dos optantes pela marca genérica pelos níveis de qualidade

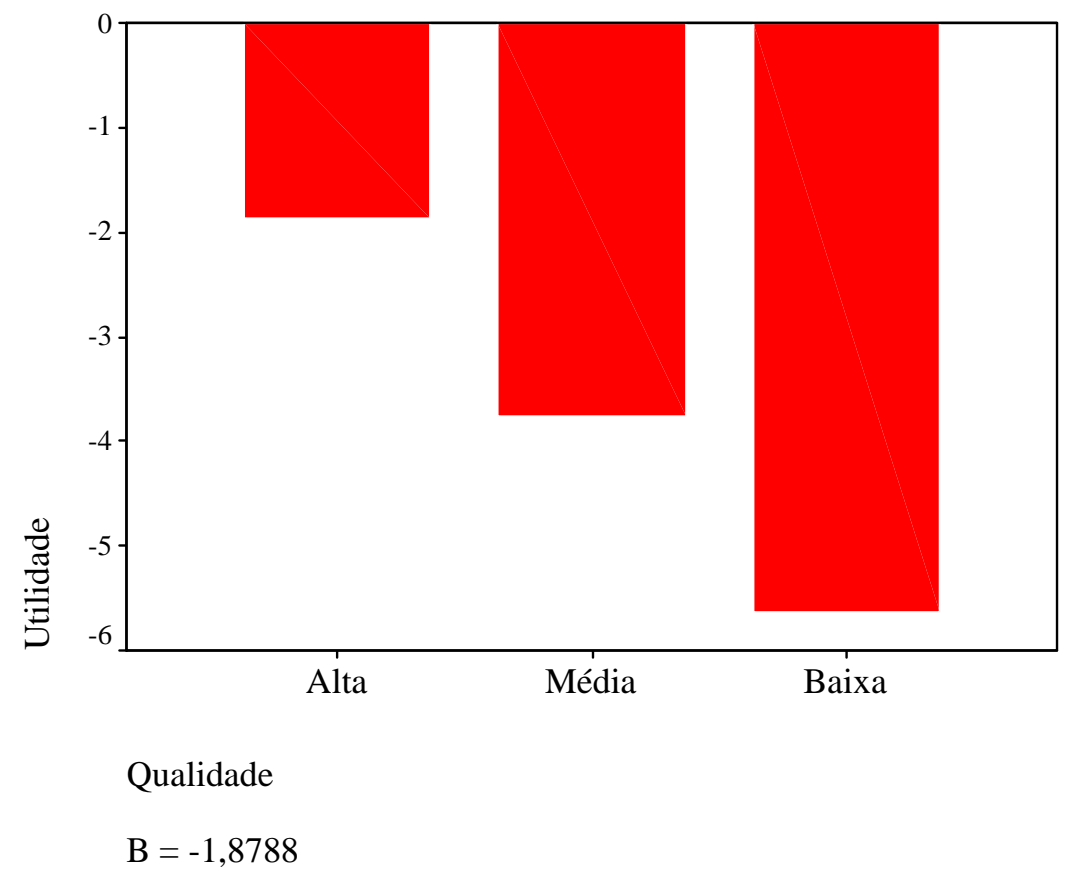

Já as respostas em relação ao fator preço, mostradas no gráfico 13, deixam clara a preferência desse grupo por camisetas com preços mais baixos, o que é coerente com a sua opção declarada pelas marcas genéricas, as quais possuem a estratégia de fornecer um determinado nível de qualidade ao menor preço possível, e com o pressuposto assumido para esse fator na execução da análise conjunta, o qual estabelecia que as pessoas preferem produtos com o menor preço em relação a similares de preço maior. 
Gráfico 13: Preferência dos optantes pela marca genérica pelos níveis de preço

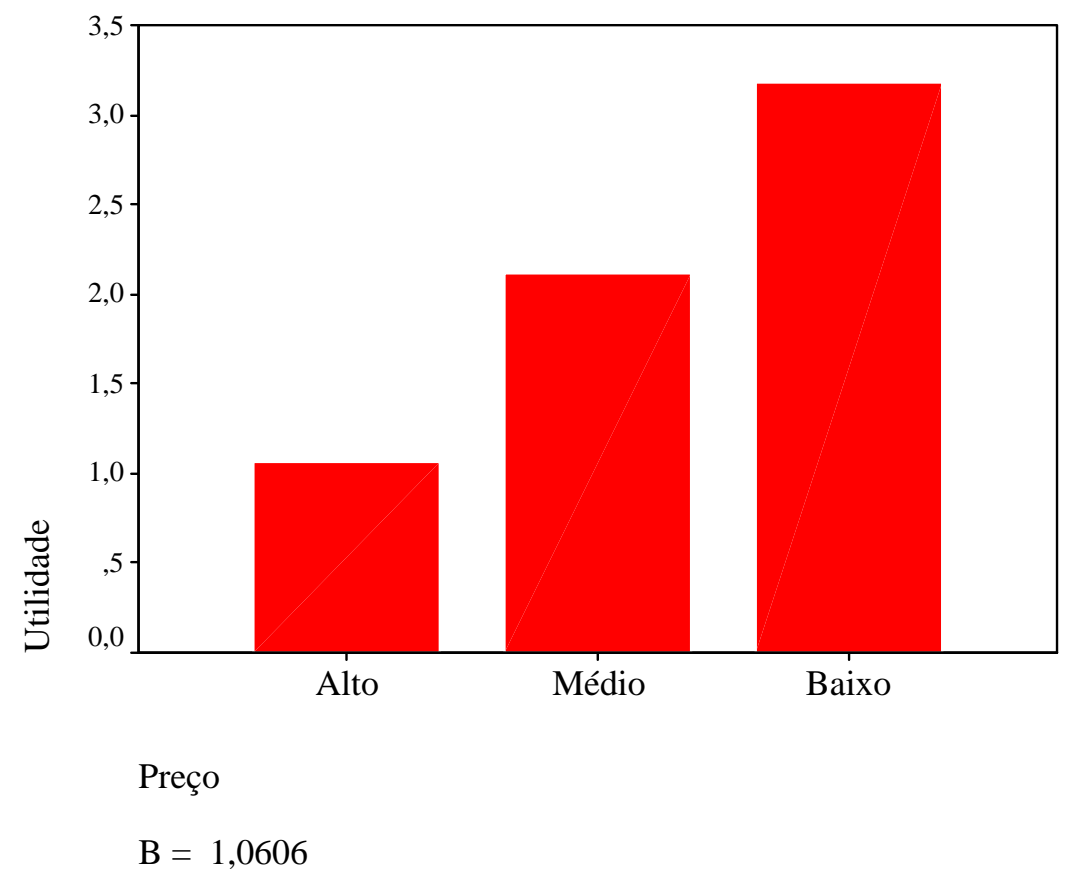

O maior impacto, assim como a maior importância, dos fatores preço e qualidade na preferência desse grupo, em relação à amostra total, revela uma maior preocupação desses respondentes por benefícios tangíveis ao invés dos imateriais, proporcionados pelas marcas, o que é coerente com a preferência declarada pela marca genérica, dado que elas baseiam-se no oferecimento do benefício material da melhor combinação possível de qualidade e preço e não desenvolvem os aspectos intangíveis.

Portanto, conforme resultados apresentados, a preferência declarada dos respondentes pela marca genérica, revelada por meio da escolha de uma de suas características básicas, é consistente com as decisões desse grupo na avaliação de camisetas. Para essas pessoas, o atributo mais importante é a qualidade, seguido pelo tipo de marca e preço, sendo que o primeiro e o terceiro apresentam uma maior relevância em comparação com a amostra total. E, a camiseta preferida por esse grupo é a que apresenta marca genérica, qualidade alta e preço baixo, igual à resposta da amostra total.

Finalmente, para testar a capacidade de previsão do modelo de preferência do grupo optante pela marca genérica avaliou-se a escolha entre as duas camisetas criadas para simulação. A que possui marca social (modelo Y), preço baixo e qualidade alta é a predileta. Mesmo apresentando marca genérica, a qual é a preferida por esses respondentes, a outra opção não foi escolhida por muitos porque esse atributo não possui utilidade suficiente para compensar o menor 
nível de qualidade, que nesse caso é média, sendo que, para eles, a qualidade tem importância maior que o tipo de marca. A tabela 7 apresenta os percentuais de preferência de cada camiseta simulada segundo os métodos de previsão de escolha utilidade máxima, BTL e Logit.

Tabela 7: Preferência dos optantes pela marca genérica pelos dois estímulos de simulação

\begin{tabular}{|l|c|c|c|}
\hline \multicolumn{1}{|c|}{ Produto simulado } & Utilidade máxima & BTL & Logit \\
\hline Camiseta modelo X, preço baixo, qualidade média & $31,82 \%$ & $47,97 \%$ & $38,47 \%$ \\
\hline Camiseta modelo Y, preço baixo, qualidade alta & $68,18 \%$ & $52,03 \%$ & $61,53 \%$ \\
\hline
\end{tabular}

Modelo de camiseta: X: Sem estampas; Y: Possui o símbolo de uma famosa causa social estampado na frente.

\subsubsection{Análise da importância dos fatores na preferência dos optantes pela marca de fabricante}

Estudando-se as pessoas que, ao escolherem a opção da camiseta que é anunciada em propagandas na TV na questão oito, foram consideradas como tendo declarado a preferência pela marca de fabricante, encontra-se um grupo composto por 73 respondentes. Os parâmetros utilizados para a análise conjunta das opiniões desse grupo permaneceram iguais aos utilizados na da amostra total.

O modelo gerado para o grupo que declarou preferir a marca de fabricante apresentou um bom ajuste aos dados (coeficiente de correlação de Kendall igual a 0,833) e forte indicação de validade interna, devido à correlação de Kendall para o conjunto de validação (holdout) ser 1. Porém, dos 73 respondentes, um apresentava dois reversals e 16 tiveram apenas um, sendo que o atributo preço foi responsável por 14 deles e a qualidade pelos outros quatro reversals. A tabela 8 reúne essas medidas de qualidade do modelo.

Tabela 8: Medidas de qualidade do modelo de preferência dos optantes pela marca de fabricante

\begin{tabular}{|c|c|c|c|c|c|}
\hline \multicolumn{2}{|c|}{ Correlação de Kendall } & \multicolumn{3}{|c|}{ Quantidade de casos com reversals } \\
\cline { 3 - 6 } & & \multicolumn{2}{|c|}{ Por quantidade } & \multicolumn{2}{c|}{ Por fatores } \\
\hline Modelo & Validação & 1 reversal & 2 reversals & Qualidade & Preço \\
\hline 0,833 & 1,000 & 16 & 1 & 4 & 14 \\
\hline
\end{tabular}

Como o modelo gerado inicialmente para o grupo que prefere as marcas de fabricante apresentou boas medidas de ajuste e validade, a fim de preservar o tamanho e a diversidade do grupo estudado, decidiu-se que não havia necessidade de remoção de casos, inclusive dos reversals, pois eles não estão comprometendo de forma relevante a qualidade do modelo e nem há necessidade de melhorá-la. Assim, o modelo sem exclusão de casos é utilizado para 
descrever a preferência de compra das pessoas que declararam optarem pelas camisetas com característica de marca de fabricante.

Na opinião do grupo que prefere a marca de fabricante, a qualidade de uma camiseta é o atributo principal (importância média de 42,26\%), sendo o tipo de marca (36,39\%) e o preço (21,34\%), respectivamente, o segundo e o terceiro em termos de relevância, como mostrado no gráfico 14. Pelo fato de esse grupo ter declarado que no momento de escolha prefere a camiseta anunciada na TV, era esperado que esse grupo atribuísse alta importância para a qualidade e o tipo de marca, sendo que a desse último fator é maior do que a obtida com a amostra total, pois pessoas que preferem a marca de fabricante tendem a se preocupar com a marca (e seus significados) que estão consumindo, a fim de transmitir os significados desejados para a sociedade, e escolhem esse tipo de marca por acreditar que os seus produtos possuem mais qualidade.

\section{Gráfico 14: Importância dos atributos da camiseta na preferência de compra dos optantes pela marca de} fabricante

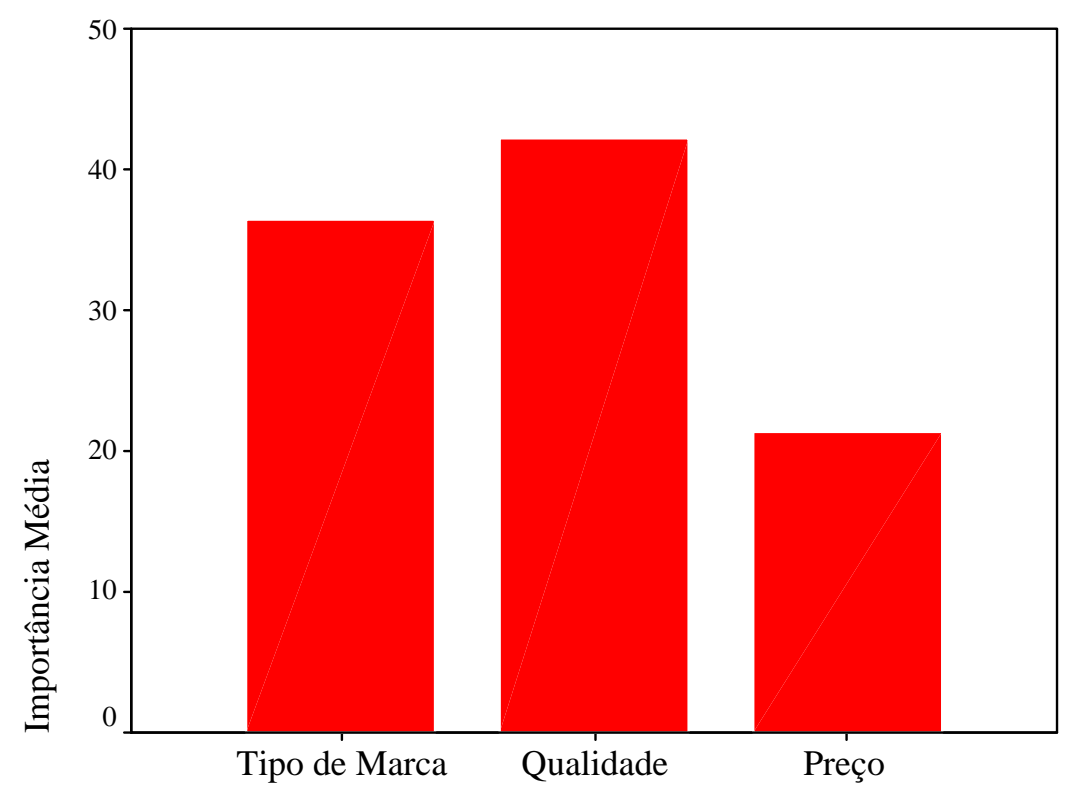

Atributo

Em relação aos tipos de marca, conforme o gráfico 15, a marca de fabricante é a preferida por esse grupo (utilidade de 0,5708). Diferentemente do ocorrido com a amostra total, a marca de fabricante agora apresenta preferência e não mais aversão do grupo analisado e, desse modo, há indício de esses respondentes serem fiéis a uma marca que atenda seus desejos e necessidades. Essa preferência pela marca de fabricante é coerente com a opção 
declarada pelo grupo em relação à camiseta anunciada na TV, visto que comunicação da marca, característica escolhida por esses respondentes, é comum a esse tipo de marca.

Também, a predileção pela marca de fabricante aliada à aversão à genérica (utilidade igual a -0,1644) revela que esse grupo é preocupado com os significados e benefícios intangíveis que uma marca pode oferecer. E, a aversão à marca social (utilidade de -0,4064) sugere que esse pode ser um grupo que, como observado por Ellwood (2004), deseja se agradar sem ficar com a consciência culpada e, desse modo, associa a marca social a grupos com estilo de vida indesejáveis.

\section{Gráfico 15: Preferência dos optantes pela marca de fabricante pelos tipos de marca}

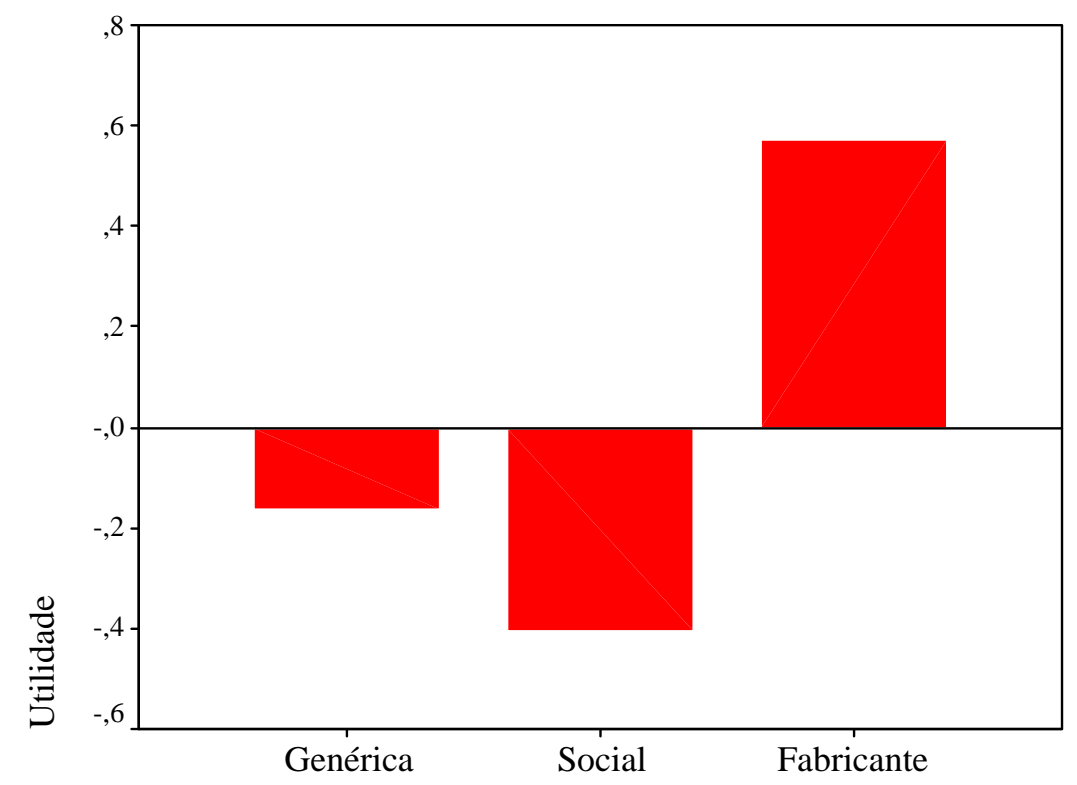

Tipo de Marca

A estrutura de preferência, do grupo que escolheu a marca de fabricante, pela qualidade apresentou, de acordo com o gráfico 16, uma maior utilidade ao nível alta $(-1,6438)$ e uma menor ao estado baixo $(-4,9315)$, sendo esse o movimento que havia sido pressuposto para o fator. Ressalta-se que os valores negativos da utilidade dos níveis do fator qualidade não ocorreram devido à aversão da amostra a eles, mas sim pelo modo como foram estabelecidos e processados pela análise conjunta. Contudo, quanto mais negativo é o valor de um nível, menor é a preferência por ele.

O impacto da qualidade $(B=-1,6438)$ na utilidade de uma camiseta, para esses respondentes, é $120 \%$ maior do que o do fator preço $(B=0,7443$, segundo apresentado no 
gráfico 17), ou seja, quando comparado com a amostra total, a qualidade é bem mais relevante para esse grupo do que o preço e essa constatação confirma que o grupo que declarou preferência pela marca de fabricante, busca não só os benefícios intangíveis dela, como também uma garantia de qualidade maior.

\section{Gráfico 16: Preferência dos optantes pela marca de fabricante pelos níveis de qualidade}

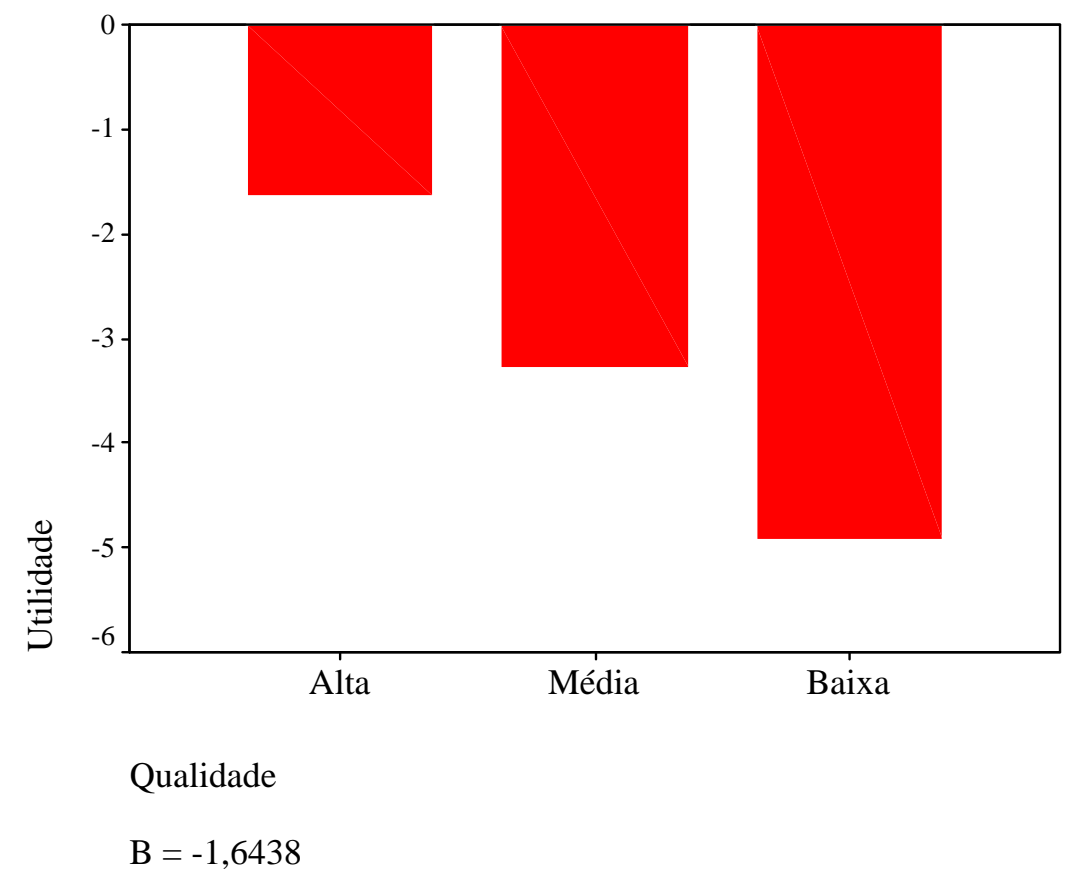

As respostas em relação ao fator preço, mostradas no gráfico 17, deixam clara a preferência desse grupo por camisetas com preços mais baixos, o que é coerente com o pressuposto assumido para esse fator na execução da análise conjunta, o qual estabelecia que as pessoas preferem produtos com o baixo preço em relação a similares de preço maior.

O menor impacto do fator preço na utilidade das camisetas para os respondentes que preferem a marca de fabricante sugere uma menor sensibilidade ao preço em benefício do maior foco em outros atributos, como a qualidade, e, dessa forma, abre a possibilidade de aplicação de preços diferenciados para marcas que atendam os interesses dessas pessoas. 


\section{Gráfico 17: Preferência dos optantes pela marca de fabricante pelos níveis de preço}

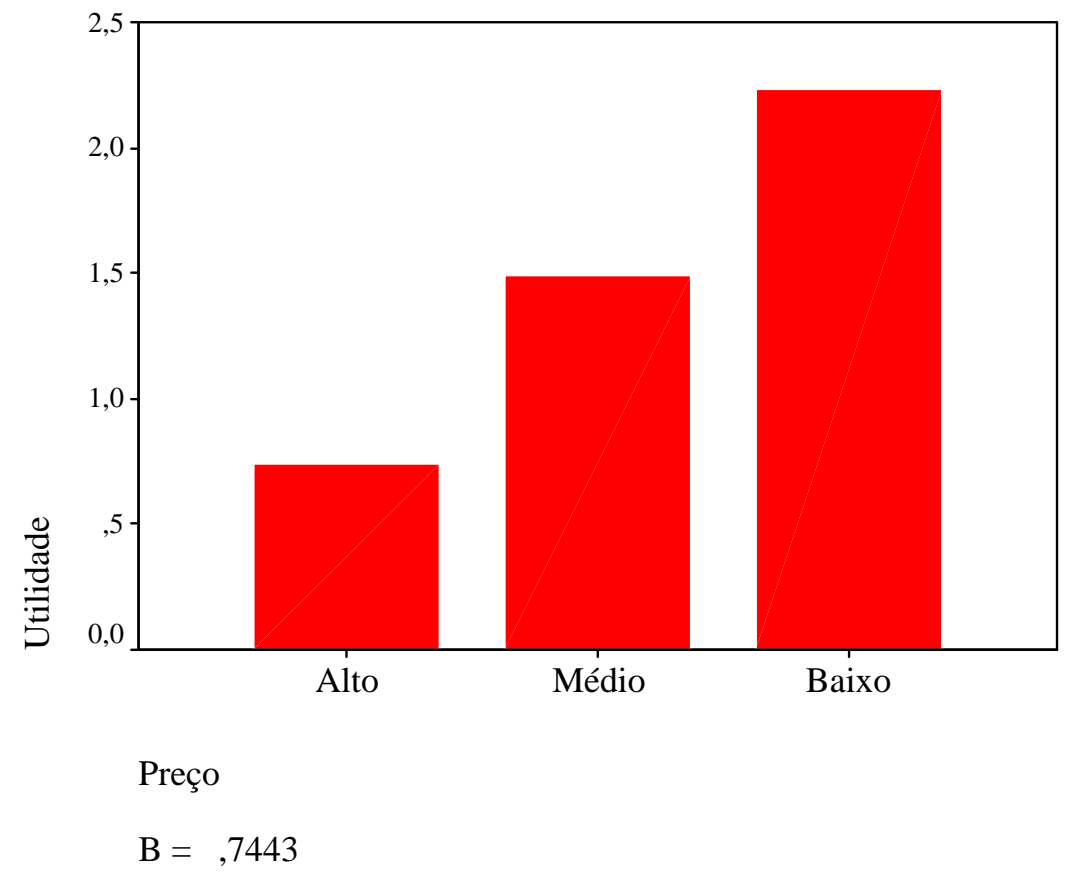

Por conseguinte, conforme resultados apresentados, a preferência declarada dos respondentes pela marca de fabricante, revelada por meio da escolha de uma de suas características básicas, é consistente com as decisões desse grupo na avaliação de camisetas. Para essas pessoas, o atributo mais importante é a qualidade, seguido pelo tipo de marca e preço, sendo que os dois últimos apresentam maior e menor importância, respectivamente, em relação ao modelo da amostra total. A camiseta preferida por esse grupo é a que apresenta marca de fabricante, qualidade alta e preço baixo, sendo que há indícios de que a escolha por esse tipo de marca ocorre devido à busca por garantia de qualidade superior e benefícios intangíveis que ela pode proporcionar. E, esse grupo aparenta ser fiel à marca que melhor lhe atende e menos sensível ao preço.

Por fim, para testar a capacidade de previsão do modelo de preferência do grupo optante pela marca de fabricante avaliou-se a escolha entre as duas camisetas criadas para simulação. A que possui marca social (modelo Y), preço baixo e qualidade alta é a predileta. Mesmo possuindo um tipo de marca com menor aversão dos respondentes, a outra opção não foi escolhida por muitos deles porque esse atributo não possui utilidade suficiente para compensar o seu menor nível de qualidade em relação ao produto preferido, sendo que, para esses participantes, a qualidade tem importância maior que o tipo de marca. A tabela 9 
apresenta os percentuais de preferência de cada camiseta simulada segundo os métodos de previsão de escolha utilidade máxima, BTL e Logit.

Tabela 9: Preferência dos optantes pela marca de fabricante pelos dois estímulos de simulação

\begin{tabular}{|l|c|c|c|}
\hline \multicolumn{1}{|c|}{ Produto simulado } & Utilidade máxima & BTL & Logit \\
\hline Camiseta modelo X, preço baixo, qualidade média & $27,40 \%$ & $45,37 \%$ & $31,09 \%$ \\
\hline Camiseta modelo Y, preço baixo, qualidade alta & $72,60 \%$ & $54,63 \%$ & $68,91 \%$ \\
\hline
\end{tabular}

Modelo de camiseta: X: Sem estampas; Y: Possui o símbolo de uma famosa causa social estampado na frente.

\subsubsection{Análise da importância dos fatores na preferência de compra dos optantes pela marca social}

Estudando-se as pessoas que, ao escolherem a opção da camiseta produzida por uma empresa engajada em alguma causa social e/ou ambiental na questão oito, foram consideradas como tendo declarado a preferência pela marca social, encontra-se um grupo composto por 81 respondentes. Os parâmetros utilizados para a análise conjunta das opiniões desse grupo permaneceram iguais aos utilizados na da amostra total.

O modelo gerado para o grupo que declarou preferir a marca social apresentou forte ajuste aos dados (coeficiente de correlação de Kendall igual a 0,889) e validade interna, devido à correlação de Kendall para o conjunto de validação (holdout) ser 1. Porém, entre os respondentes, um apresentava dois reversals e 12 tiveram apenas um, sendo que o atributo preço foi responsável por nove deles e a qualidade pelos outros cinco reversals. A tabela 10 reúne essas medidas de qualidade do modelo.

Tabela 10: Medidas de qualidade do modelo de preferência dos optantes pela marca social

\begin{tabular}{|c|c|c|c|c|c|}
\hline \multicolumn{2}{|c|}{ Correlação de Kendall } & \multicolumn{3}{|c|}{ Quantidade de casos com reversals } \\
\cline { 3 - 6 } & & \multicolumn{2}{|c|}{ Por quantidade } & \multicolumn{2}{c|}{ Por fatores } \\
\hline Modelo & Validação & 1 reversal & 2 reversals & Qualidade & Preço \\
\hline 0,889 & 1,000 & 12 & 1 & 5 & 9 \\
\hline
\end{tabular}

Como o modelo gerado inicialmente para o grupo que prefere as marcas sociais apresentou boas medidas de ajuste e validade, a fim de preservar o tamanho e a diversidade do grupo estudado, decidiu-se que não havia necessidade para remoção de casos, inclusive dos reversals, pois eles não estão comprometendo de forma relevante a qualidade do modelo e nem há necessidade de melhorá-la. Assim, o modelo sem exclusão de casos é utilizado para descrever a preferência de compra das pessoas que declararam optarem pelas camisetas com característica de marca social. 
Na opinião do grupo que prefere a marca social, a qualidade de uma camiseta é o atributo principal (importância média de 42,89\%), sendo o tipo de marca (33,65\%) e o preço (23,46\%), respectivamente, o segundo e o terceiro em termos de relevância, como mostrado no gráfico 18. A preferência por um tipo de marca diferente da genérica impacta na importância desse atributo, tornando-a maior do que a obtida com a amostra total, o que mostra que esse consumidor é menos indiferente às opções de marca ao preferir, declaradamente, uma delas.

\section{Gráfico 18: Importância dos atributos da camiseta na preferência de compra dos optantes pela marca social}

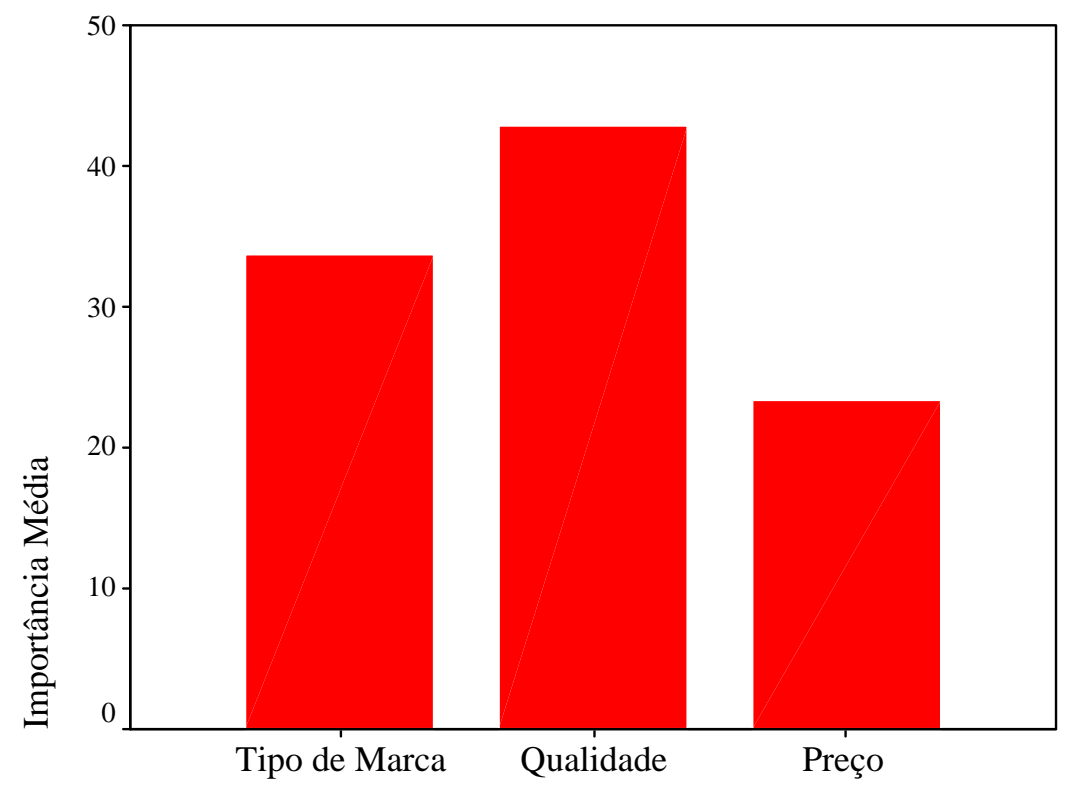

Atributo

Em relação aos tipos de marca, conforme o gráfico 19, a marca social é a preferida por esse grupo (utilidade de 0,4527). Diferentemente do ocorrido com a amostra total, a marca social agora apresenta preferência e não mais aversão do grupo analisado e, desse modo, há indício de esses respondentes serem fiéis a uma marca que atenda seus desejos e necessidades. Essa preferência pela marca social é coerente com a opção declarada pelo grupo em relação à camiseta de uma empresa engajada em causas sócio-ambientais, visto que o envolvimento com essas causas, característica escolhida por esses respondentes, é comum a esse tipo de marca.

A predileção pela marca social aliada à forte aversão à de fabricante (utilidade igual a -0,5967) e a baixa preferência - e não aversão - à marca genérica (utilidade de 0,1440) sugerem que esse grupo é preocupado com os benefícios sócio-ambientais que uma marca 
pode oferecer e não com as associações obtidas por meio dela, ou seja, se a marca não tivesse apelo social, essas pessoas escolheriam um produto sem significados e comunicação aparente, por evitar expor publicamente seus valores e idéias. Uma hipótese que pode ser formulada para essa aversão à marca de fabricante pelo grupo é a ligação dela a práticas empresariais agressivas e que muitas vezes não são sócio e nem ambientalmente corretas.

\section{Gráfico 19: Preferência dos optantes pela marca social pelos tipos de marca}

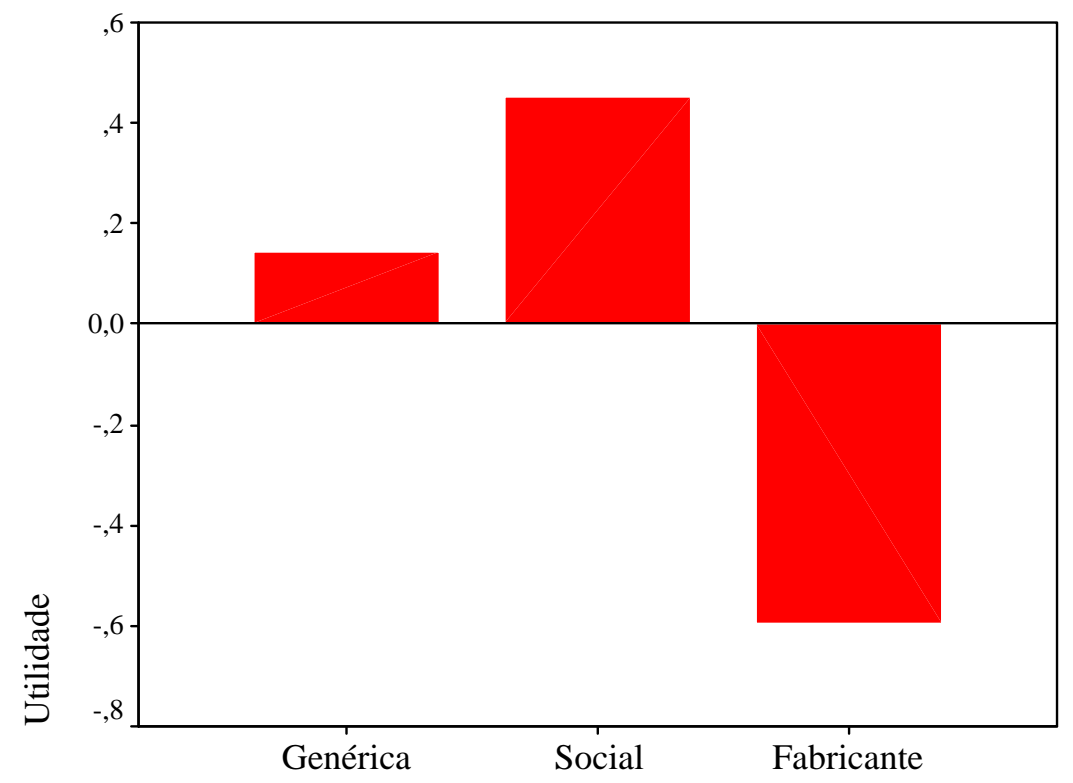

Tipo de Marca

A estrutura de preferência, do grupo que escolheu a marca social, pela qualidade apresentou, de acordo com o gráfico 20, uma maior utilidade ao nível alta (-1,7243) e uma menor ao estado baixo $(-5,1728)$, sendo esse o movimento que havia sido pressuposto para o fator. Ressalta-se que os valores negativos da utilidade dos níveis do fator qualidade não ocorreram devido à aversão da amostra a eles, mas sim pelo modo como foram estabelecidos e processados pela análise conjunta. Contudo, quanto mais negativo é o valor de um nível, menor é a preferência por ele.

O impacto da qualidade $(B=-1,7243)$ na utilidade de uma camiseta, para esses respondentes, é $101 \%$ maior do que o do fator preço ( $\mathrm{B}=0,8560$, como mostrado no gráfico 21), ou seja, quando comparado com a amostra total, a qualidade é bem mais relevante para esse grupo do que o preço e essa constatação confirma que o grupo que declarou preferência pela marca social, busca não só os benefícios dela, como também uma garantia de qualidade (do produto ou das ações da empresa) maior. Porém, não sendo qualidade o principal interesse desse grupo e nem 
a medida exata da contribuição sócio-ambiental de uma marca, que é a preocupação dessas pessoas, o impacto desse fator para os respondentes que preferem a marca social é menor do que para os que optaram pela de fabricante, para os quais a qualidade é muito importante e a marca é um signo fundamental na garantia e transmissão de um nível superior desse atributo.

\section{Gráfico 20: Preferência dos optantes pela marca social pelos níveis de qualidade}

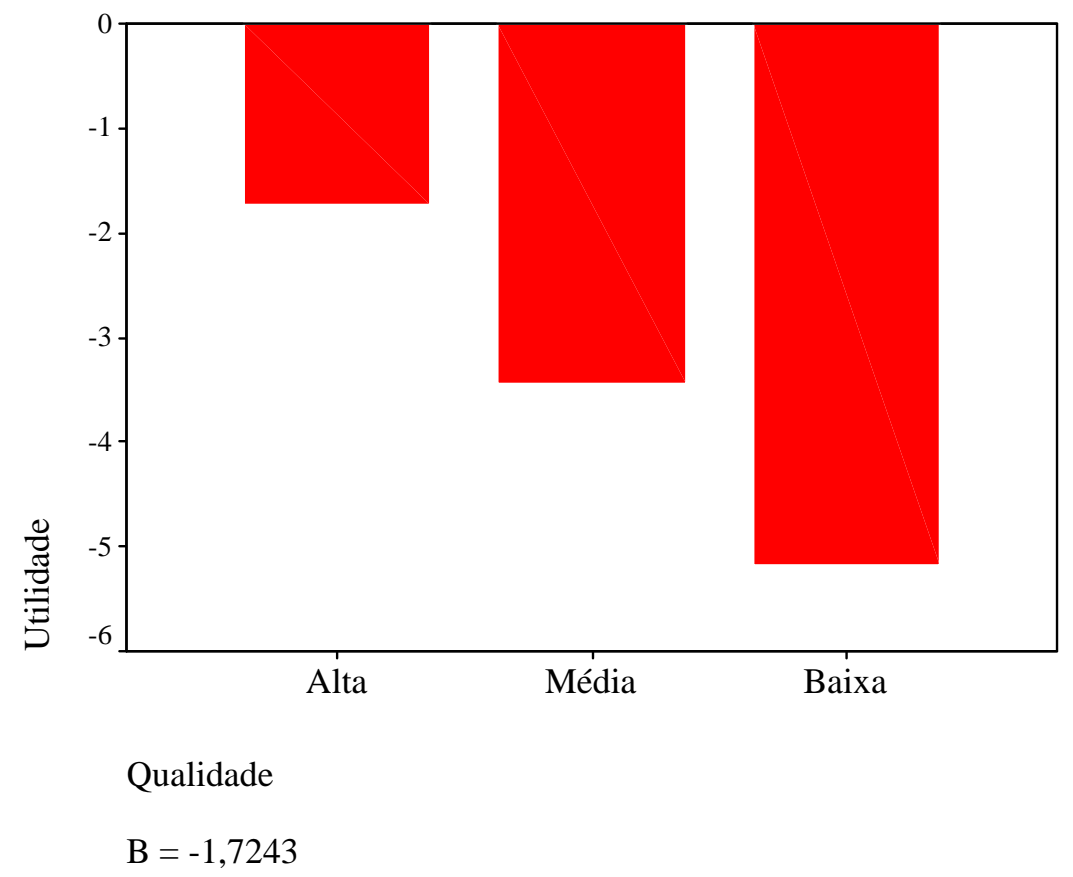

As respostas em relação ao fator preço, mostradas no gráfico 21, deixam clara a preferência desse grupo por camisetas com preços mais baixos, o que é coerente com o pressuposto assumido para esse fator na execução da análise conjunta, o qual estabelecia que as pessoas preferem produtos com o baixo preço em relação a similares de preço maior.

O menor impacto do fator preço na utilidade das camisetas para os respondentes que preferem a marca social sugere uma menor sensibilidade ao preço em benefício do maior foco em outros atributos, como a contribuição à causa, e, dessa forma, abre a possibilidade de aplicação de preços diferenciados para marcas que atendam os interesses dessas pessoas.

Assim, conforme resultados apresentados, a preferência declarada dos respondentes pela marca social, revelada por meio da escolha de uma de suas características básicas, é consistente com as decisões desse grupo na avaliação de camisetas. Para essas pessoas, o atributo mais importante é a qualidade, seguido pelo tipo de marca e preço. A camiseta preferida por esse grupo é a que apresenta marca social, qualidade alta e preço baixo, sendo que há indícios de que a escolha por esse tipo de marca ocorre devido à preocupação com os benefícios sócio- 
ambientais que uma marca pode oferecer e não com as associações obtidas por meio dela. E, esse grupo aparenta ser fiel à marca que melhor lhe atende e menos sensível ao preço.

\section{Gráfico 21: Preferência dos optantes pela marca social pelos níveis de preço}

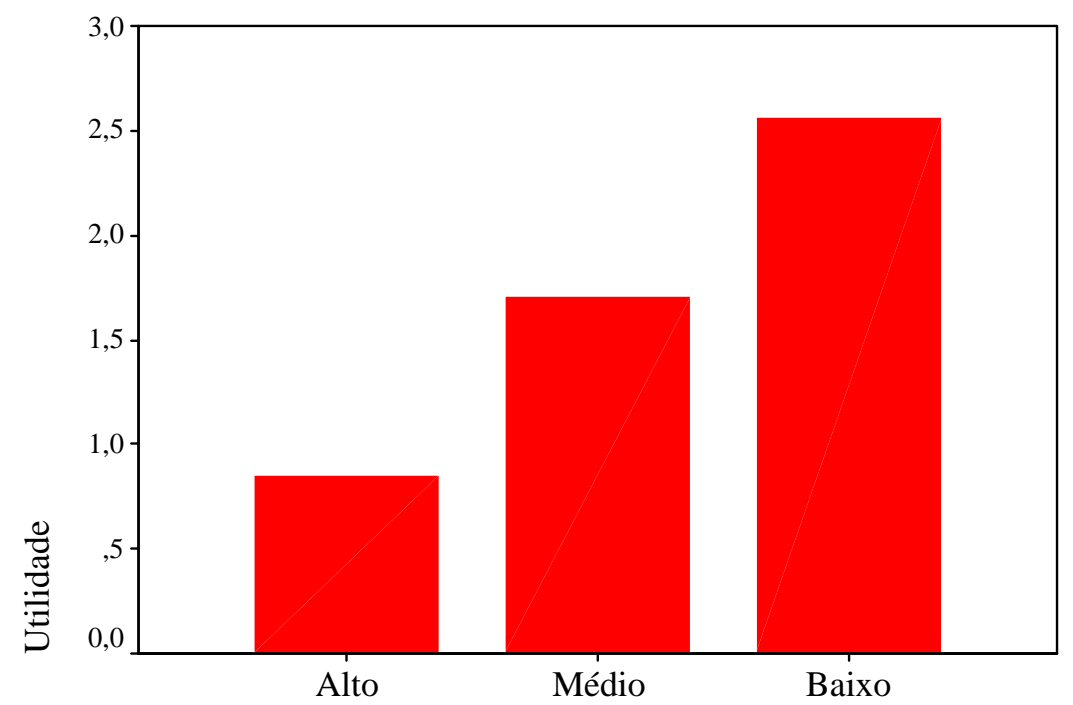

Preço
$\mathrm{B}=, 8560$

Por fim, para testar a capacidade de previsão do modelo de preferência do grupo optante pela marca social avaliou-se a escolha entre as duas camisetas criadas para simulação. Como esperado, a que possui marca social (modelo Y), preço baixo e qualidade alta é a predileta, pois é justamente a composição da camiseta ideal para esse grupo e, desse modo, ela teve uma preferência muito maior do que a obtida nos grupos de respondentes optantes dos outros tipos de marca e na amostra total.

A outra opção simulada não foi escolhida por muitos membros do grupo de optantes pela marca social, pois apresentava um tipo de marca - a genérica - com baixa preferência mas não aversão - e um menor nível de qualidade em relação ao produto preferido, sendo que, para esses respondentes, também, a qualidade tem grande importância. A tabela 11 apresenta os percentuais de preferência de cada camiseta simulada segundo os métodos de previsão de escolha utilidade máxima, BTL e Logit.

Tabela 11: Preferência dos optantes pela marca social pelos dois estímulos de simulação

\begin{tabular}{|c|c|c|c|}
\hline Produto simulado & Utilidade máxima & BTL & Logit \\
\hline Camiseta modelo X, preço baixo, qualidade média & $19,75 \%$ & $42,88 \%$ & $23,93 \%$ \\
\hline Camiseta modelo Y, preço baixo, qualidade alta & $80,25 \%$ & $57,12 \%$ & $76,07 \%$ \\
\hline
\end{tabular}

Modelo de camiseta: X: Sem estampas; Y: Possui o símbolo de uma famosa causa social estampado na frente. 


\subsubsection{Análise da importância dos fatores na preferência de compra das pessoas segundo o gênero sexual}

Possuindo a identificação dos respondentes por gênero sexual, decidiu-se comparar as opiniões dos homens e mulheres em relação às camisetas e seus atributos. Conforme apresentado anteriormente, a amostra possui uma equilibrada distribuição entre homens e mulheres, sendo 122 e 126 pessoas, respectivamente. Os parâmetros utilizados para a análise conjunta das opiniões desses grupos permaneceram iguais aos utilizados na da amostra total.

O modelo gerado para os homens da amostra apresentou razoável ajuste aos dados (coeficiente de correlação de Kendall igual a 0,778); porém, possuía baixa validade interna, apresentando um valor de correlação de Kendall para o conjunto de validação (holdout) de 0,333. E, dos 122 respondentes, três apresentaram dois reversals e 21 tiveram apenas um, sendo que o atributo preço foi responsável por 18 deles e a qualidade pelos outros nove reversals. A tabela 12 reúne essas medidas de qualidade do modelo.

Tabela 12: Medidas de qualidade do modelo de preferência dos homens da amostra

\begin{tabular}{|c|c|c|c|c|c|}
\hline \multicolumn{2}{|c|}{ Correlação de Kendall } & \multicolumn{3}{|c|}{ Quantidade de casos com reversals } \\
\cline { 3 - 6 } & & \multicolumn{2}{|c|}{ Por quantidade } & \multicolumn{2}{c|}{ Por fatores } \\
\hline Modelo & Validação & 1 reversal & 2 reversals & Qualidade & Preço \\
\hline 0,778 & 0,333 & 21 & 3 & 9 & 18 \\
\hline
\end{tabular}

A fim de melhorar a qualidade do modelo de preferência gerado para os homens da amostra, procedeu-se com a remoção de alguns casos. Igual ao feito no modelo gerado para a amostra total, primeiramente, retiraram-se os 24 casos com reversals. E, como nenhuma melhora ocorreu na correlação de Kendall para o conjunto de validação, após a exclusão desses 24 respondentes, procedeu-se com a remoção dos casos que não possuíam reversals, mas que tivessem o módulo da correlação de validação menor ou igual a 0,333 e da correlação da modelagem abaixo de 0,778 .

A ordem de exclusão desses casos foi do menor módulo de correlação de Kendall do modelo ao mais próximo do valor 0,778 , sendo que, após a exclusão de cada caso, era avaliada a possível melhora dos indicadores de qualidade do modelo antes da próxima retirada. Para melhoria dos indicadores de qualidade do modelo, foram necessárias mais 14 exclusões, totalizando 38 casos retirados de uma amostra de 122, conforme apresentado na tabela 13. 
Tabela 13: Casos excluídos para melhoria do modelo dos homens da amostra

\begin{tabular}{|c|c|c|c|}
\hline Código do Caso & $\begin{array}{c}\text { Correlação de Kendall } \\
\text { do modelo }\end{array}$ & $\begin{array}{c}\text { Correlação de Kendall } \\
\text { da validação }\end{array}$ & Quantidade de reversals \\
\hline 14 & 0,722 & 0,333 & - \\
\hline 20 & 0,514 & 0,816 & 1 \\
\hline 27 & 1,000 & 1,000 & 1 \\
\hline 31 & 0,629 & 0,333 & - \\
\hline 38 & 0,722 & 0,333 & - \\
\hline 39 & 0,833 & 1,000 & 1 \\
\hline 43 & 0,722 & 0,333 & - \\
\hline 47 & 0,761 & 0,333 & - \\
\hline 50 & 0,743 & 0,333 & - \\
\hline 51 & 0,500 & 0,333 & 1 \\
\hline 55 & 0,667 & 1,000 & 1 \\
\hline 70 & 0,611 & 0,333 & - \\
\hline 72 & 0,535 & 0,333 & - \\
\hline 76 & 0,278 & $-0,333$ & 2 \\
\hline 82 & 0,500 & 0,333 & - \\
\hline 83 & 0,743 & 1,000 & 1 \\
\hline 87 & 0,167 & 0,333 & 1 \\
\hline 101 & 0,889 & 1,000 & 2 \\
\hline 121 & 0,833 & $-0,333$ & 1 \\
\hline 126 & 0,889 & 1,000 & 1 \\
\hline 133 & 0,704 & 0,333 & - \\
\hline 140 & 0,889 & 1,000 & 1 \\
\hline 145 & 0,535 & 0,333 & 1 \\
\hline 146 & 0,548 & 0,816 & 1 \\
\hline 148 & 0,889 & 0,333 & 1 \\
\hline 154 & 0,366 & $-0,333$ & 1 \\
\hline 165 & 0,667 & 0,333 & - \\
\hline 169 & 0,889 & 1,000 & 2 \\
\hline 184 & 1,000 & 1,000 & 1 \\
\hline 186 & 0,817 & 1,000 & 1 \\
\hline 194 & 0,261 & 0,333 & 1 \\
\hline 196 & 0,778 & 0,333 & 1 \\
\hline 201 & 0,444 & $-0,333$ & 1 \\
\hline 207 & 0,722 & 0,333 & - \\
\hline 217 & 0,686 & 0,333 & 1 \\
\hline 226 & 0,857 & 0,333 & 1 \\
\hline 227 & 0,761 & 0,333 & - \\
\hline 237 & 0,545 & 0,333 & - \\
\hline
\end{tabular}

O modelo de preferência de compra dos homens da amostra gerado após as exclusões apresentou um melhor ajuste aos dados, sendo a nova correlação de postos de Kendall do modelo de 0,873 , e um bom grau de validade interna, visto que a correlação de Kendall para o conjunto de validação (holdout) passou para 0,816. Desse modo, esse é o modelo adotado para descrever a preferência de compra dos homens da amostra. Devido aos critérios de exclusão adotados, o número de reversals foi zero.

Já o modelo gerado para as mulheres da amostra apresentou um forte ajuste aos dados (coeficiente de correlação de Kendall igual a 0,889); porém, possuía baixa validade interna, 
apresentando um valor de correlação de Kendall para o conjunto de validação (holdout) de 0,333. E, dos 126 respondentes, dois apresentaram dois reversals e 21 tiveram apenas um, sendo que o atributo preço foi responsável por 19 deles e a qualidade pelos outros seis reversals. A tabela 14 reúne essas medidas de qualidade do modelo.

Tabela 14: Medidas de qualidade do modelo de preferência das mulheres da amostra

\begin{tabular}{|c|c|c|c|c|c|}
\hline \multicolumn{2}{|c|}{ Correlação de Kendall } & \multicolumn{3}{|c|}{ Quantidade de casos com reversals } \\
\cline { 3 - 6 } & & \multicolumn{2}{|c|}{ Por quantidade } & \multicolumn{2}{c|}{ Por fatores } \\
\hline Modelo & Validação & 1 reversal & 2 reversals & Qualidade & Preço \\
\hline 0,889 & 0,333 & 21 & 2 & 6 & 19 \\
\hline
\end{tabular}

A fim de melhorar a qualidade do modelo de preferência gerado para as mulheres da amostra, procedeu-se com a remoção de alguns casos. Igual ao feito no modelo gerado para os homens da amostra, primeiramente, retiraram-se os 23 casos com reversals. E, como nenhuma melhora ocorreu na correlação de Kendall para o conjunto de validação, após a exclusão desses 23 respondentes, procedeu-se com a remoção dos casos que não possuíam reversals, mas que tivessem o módulo da correlação de validação menor ou igual a 0,333 e da correlação da modelagem abaixo de 0,743.

A ordem de exclusão desses casos foi do menor módulo de correlação de Kendall do modelo ao mais próximo do valor 0,743 , sendo que, após a exclusão de cada caso, era avaliada a possível melhora dos indicadores de qualidade do modelo antes da próxima retirada, o que resultou na manutenção de quatro casos que possuíam correlação de Kendall do modelo e de validação igual a 0,722 e 0,333, respectivamente, enquanto outros dois que possuíam os mesmos valores foram excluídos. Para melhoria dos indicadores de qualidade do modelo, foram necessárias mais 11 exclusões, totalizando 35 casos retirados de uma amostra de 126, conforme apresentado na tabela 15.

O modelo de preferência de compra da amostra gerado após as exclusões manteve o nível de ajuste aos dados, visto que a correlação de postos de Kendall do modelo permaneceu em 0,889, e agora ele possui um bom grau de validade interna, dado que a correlação de Kendall para o conjunto de validação (holdout) passou para 0,816. Desse modo, esse é o modelo adotado para descrever a preferência de compra das mulheres da amostra. Devido aos critérios de exclusão adotados, o número de reversals foi zero. 
Tabela 15: Casos excluídos para melhoria do modelo das mulheres da amostra

\begin{tabular}{|c|c|c|c|}
\hline Código do Caso & $\begin{array}{c}\text { Correlação de Kendall } \\
\text { do modelo }\end{array}$ & $\begin{array}{c}\text { Correlação de Kendall } \\
\text { da validação }\end{array}$ & Quantidade de reversals \\
\hline 7 & 0,333 & 0,333 & - \\
\hline 9 & 0,704 & 0,333 & - \\
\hline 12 & 0,817 & 1,000 & 1 \\
\hline 35 & 0,592 & 0,333 & - \\
\hline 36 & 0,667 & 0,333 & - \\
\hline 37 & 0,667 & $-0,333$ & 1 \\
\hline 53 & 0,254 & $-0,333$ & 2 \\
\hline 65 & 0,648 & 0,333 & 1 \\
\hline 91 & 0,648 & 0,333 & - \\
\hline 153 & 0,377 & $-1,000$ & 1 \\
\hline 159 & 0,611 & 0,333 & 1 \\
\hline 160 & 0,704 & 0,333 & - \\
\hline 166 & 0,889 & 1,000 & 2 \\
\hline 168 & 0,913 & 0,333 & 1 \\
\hline 174 & 0,722 & 0,333 & - \\
\hline 178 & 0,704 & 0,333 & - \\
\hline 185 & 0,722 & 0,333 & - \\
\hline 187 & 0,761 & 0,333 & 1 \\
\hline 190 & 0,833 & 0,333 & 1 \\
\hline 192 & 0,833 & $-0,333$ & 1 \\
\hline 200 & 1,000 & 1,000 & 1 \\
\hline 203 & 1,000 & 0,333 & 1 \\
\hline 205 & 0,778 & 0,816 & 1 \\
\hline 209 & 0,928 & $-0,333$ & 1 \\
\hline 210 & 0,944 & 1,000 & 1 \\
\hline 211 & 0,704 & 0,333 & - \\
\hline 213 & 0,592 & 0,333 & 1 \\
\hline 215 & 0,667 & 0,333 & - \\
\hline 216 & 0,889 & 0,333 & 1 \\
\hline 223 & 0,611 & 0,333 & - \\
\hline 225 & 1,000 & 1,000 & 1 \\
\hline 232 & 0,833 & 0,333 & 1 \\
\hline 234 & 0,889 & 1,000 & 1 \\
\hline 247 & 0,778 & 0,333 & 1 \\
\hline 248 & 0,889 & 1,000 & 1 \\
\hline
\end{tabular}

Na opinião dos homens da amostra, a qualidade de uma camiseta é o atributo principal (importância média de 45,39\%), sendo o tipo de marca $(28,68 \%)$ e o preço $(25,94 \%)$, respectivamente, o segundo e o terceiro em termos de relevância, como mostrado no gráfico 22. O mesmo ocorre com as mulheres, para quem a importância da qualidade, tipo de marca e preço é, em igual ordem, 41,68\%, 37,57\% e 20,75\%.

Nota-se que o tipo de marca tem uma relevância maior para as mulheres do que para os homens, já com o preço e a qualidade ocorre o contrário. Essa maior importância atribuída pelas mulheres ao tipo de marca mostra o grande interesse delas pelos benefícios intangíveis que a camiseta pode lhe dar por meio da sua marca; já os homens têm maior foco nos ganhos 
tangíveis que esse produto pode proporcionar e, desse modo, atribuem menor importância para a marca e maior para a qualidade e preço dele.

Gráfico 22: Importância dos atributos da camiseta na preferência de compra dos homens e mulheres da amostra

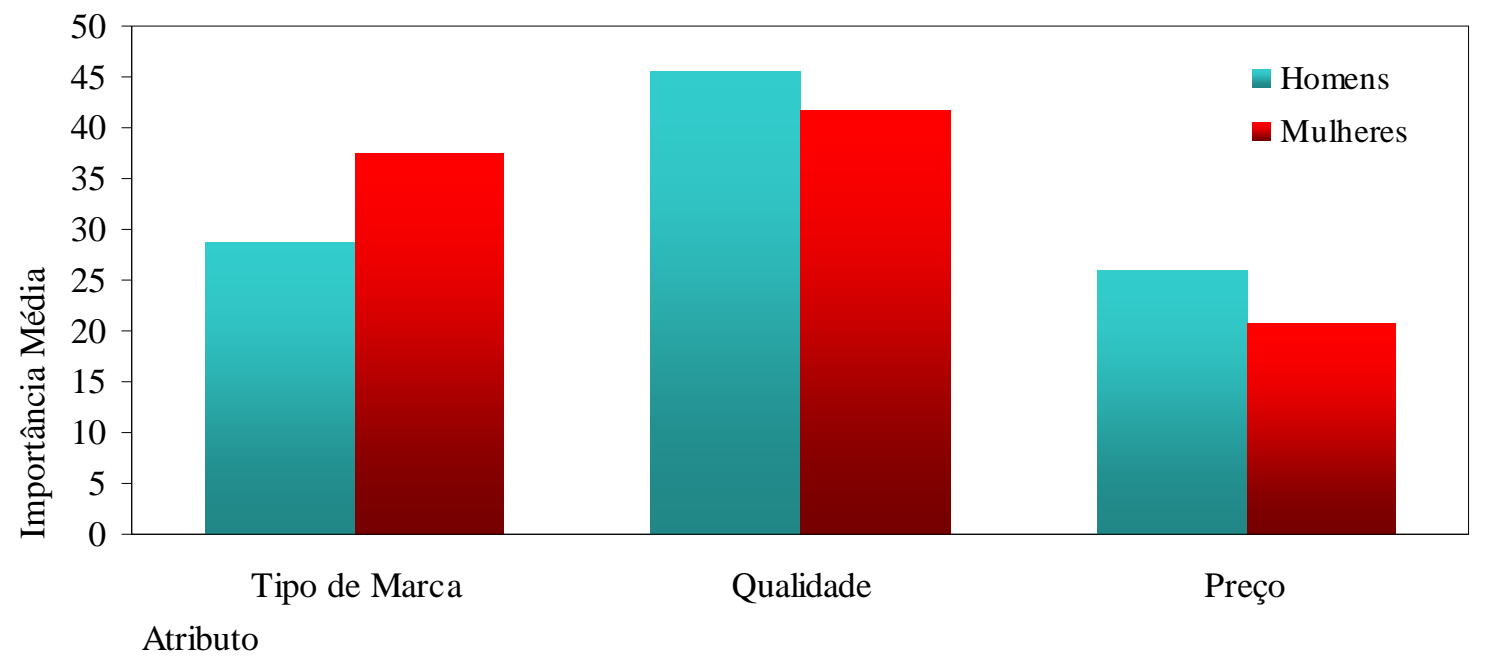

Gráfico 23: Preferência dos homens e mulheres da amostra pelos tipos de marca

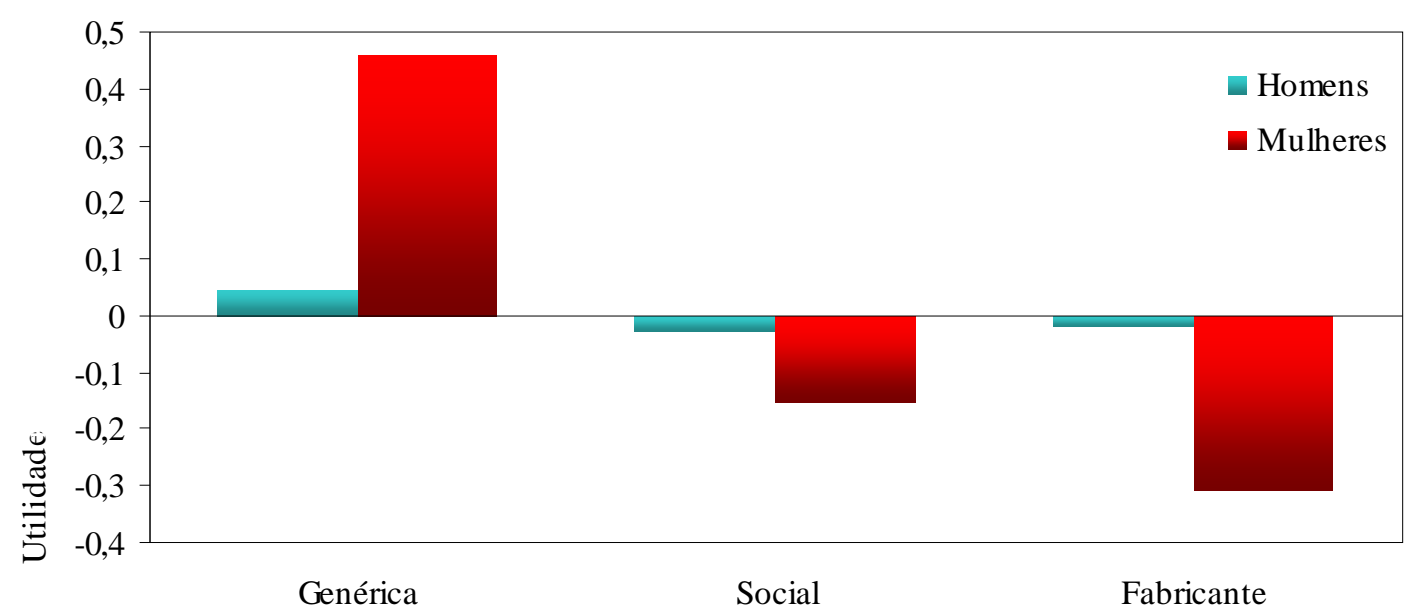

Tipo de Marca

Em relação aos tipos de marca, conforme o gráfico 23, a marca genérica é a preferida tanto por homens quanto por mulheres (utilidade de 0,0476 e 0,4579, na mesma ordem). A marca social e de fabricante possui aversão de ambos os grupos, porém, sendo que para as mulheres a utilidade das duas é menor, -0,1502 e -0,3077, respectivamente, enquanto que para os homens a utilidade da primeira é -0,0278 e da segunda é -0,0198. A utilidade da marca 
social entre os dois gêneros sexuais é diferente do que foi encontrado no estudo da Letshal, citado por Magalhães (2011), o qual concluía que as mulheres se preocupam mais em ajudar os outros do que os homens e, desse modo, esperava-se que a aversão do grupo feminino da amostra à marca social fosse menor, o que não ocorreu.

Essa estrutura de preferência entre os tipos de marca sugere que a mulher se importa com a marca principalmente por preferir as que não transmitam explicitamente valores e idéias por meio de signos ou imagens estampados, ou seja, preferem camisetas genéricas, sem mensagens e símbolos. Enquanto os homens da amostra, por apresentarem a utilidade dos três níveis muito próxima, aparentam serem indiferentes aos tipos de marca - embora prefiram a marca genérica e terem maior interesse em aspectos materiais do produto, como qualidade e preço. Assim, devido à maior preferência pela marca genérica, percebe-se uma menor possibilidade de se desenvolver a fidelidade à marca entre as mulheres e homens da amostra.

A ordem de preferência dos homens e mulheres da amostra pela qualidade apresentou, de acordo com o gráfico 24, uma maior utilidade ao nível alta (-1,9306 e -1,7564, respectivamente) e uma menor ao estado baixo (-5,7917 para os homens e -5,2692 para as mulheres), sendo esse o movimento que havia sido pressuposto para o fator. Ressalta-se que os valores negativos da utilidade dos níveis do fator qualidade não ocorreram devido à aversão da amostra a eles, mas sim pelo modo como foram estabelecidos e processados pela análise conjunta. Contudo, quanto mais negativo é o valor de um nível, menor é a preferência por ele.

\section{Gráfico 24: Preferência dos homens e mulheres da amostra pelos níveis de qualidade}

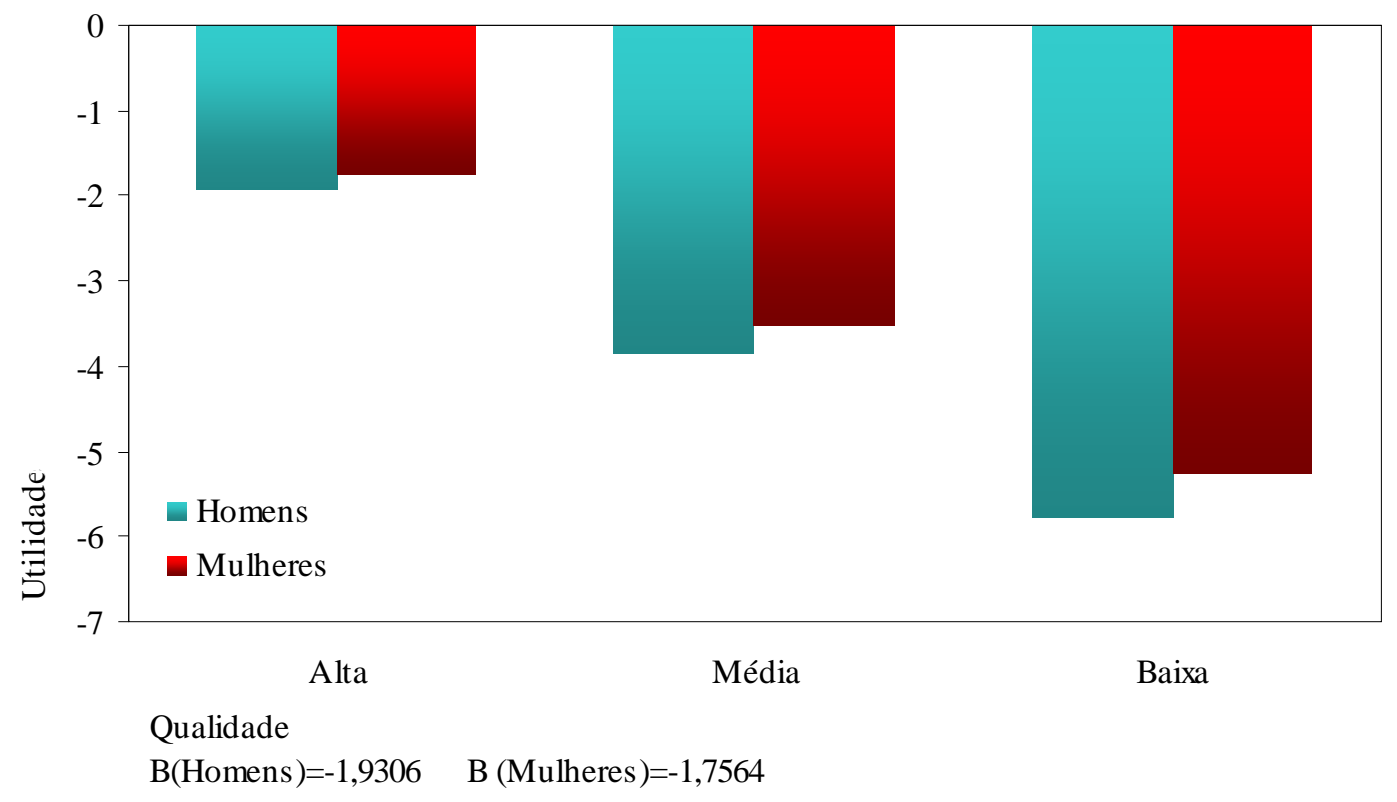


Devido ao maior interesse do grupo masculino nos benefícios tangíveis, a qualidade acabou apresentando maior impacto para ele $(B=-1,9306)$ do que para as mulheres $(B=-$ 1,7564). E, o impacto da qualidade na utilidade de uma camiseta é 70,7\% e 97,7\% maior do que o do preço $\left(B_{\text {homens }}=1,1310\right.$ e $B_{\text {mulheres }}=0,8883$, segundo o gráfico 25) para os homens e mulheres da amostra, respectivamente. Assim, como já observado anteriormente, os homens atribuem maior relevância ao atributo preço em relação à qualidade do que as mulheres, o que sugere que eles possuem um maior equilíbrio na ponderação entre preço e qualidade quando comparado a elas, enquanto as mulheres, embora se preocupem com o tipo de marca a fim de evitar a transmissão pública dos seus valores e idéias, ao mesmo tempo, escolhem-nas entre as opções que lhe agradam para garantir um determinado nível de qualidade.

As respostas em relação ao fator preço, mostradas no gráfico 25, deixam clara a preferência de ambos os sexos por camisetas com preços mais baixos, o que é coerente com o pressuposto assumido para esse fator na execução da análise conjunta, o qual estabelecia que as pessoas preferem produtos com o baixo preço em relação a similares de preço maior.

O menor impacto do fator preço na utilidade das camisetas para as mulheres da amostra sugere uma menor sensibilidade ao preço em benefício do maior foco em outros atributos, como a qualidade, e, dessa forma, abre a possibilidade de aplicação de preços diferenciados para marcas que atendam os interesses dessas pessoas.

\section{Gráfico 25: Preferência dos homens e mulheres da amostra pelos níveis de preço}

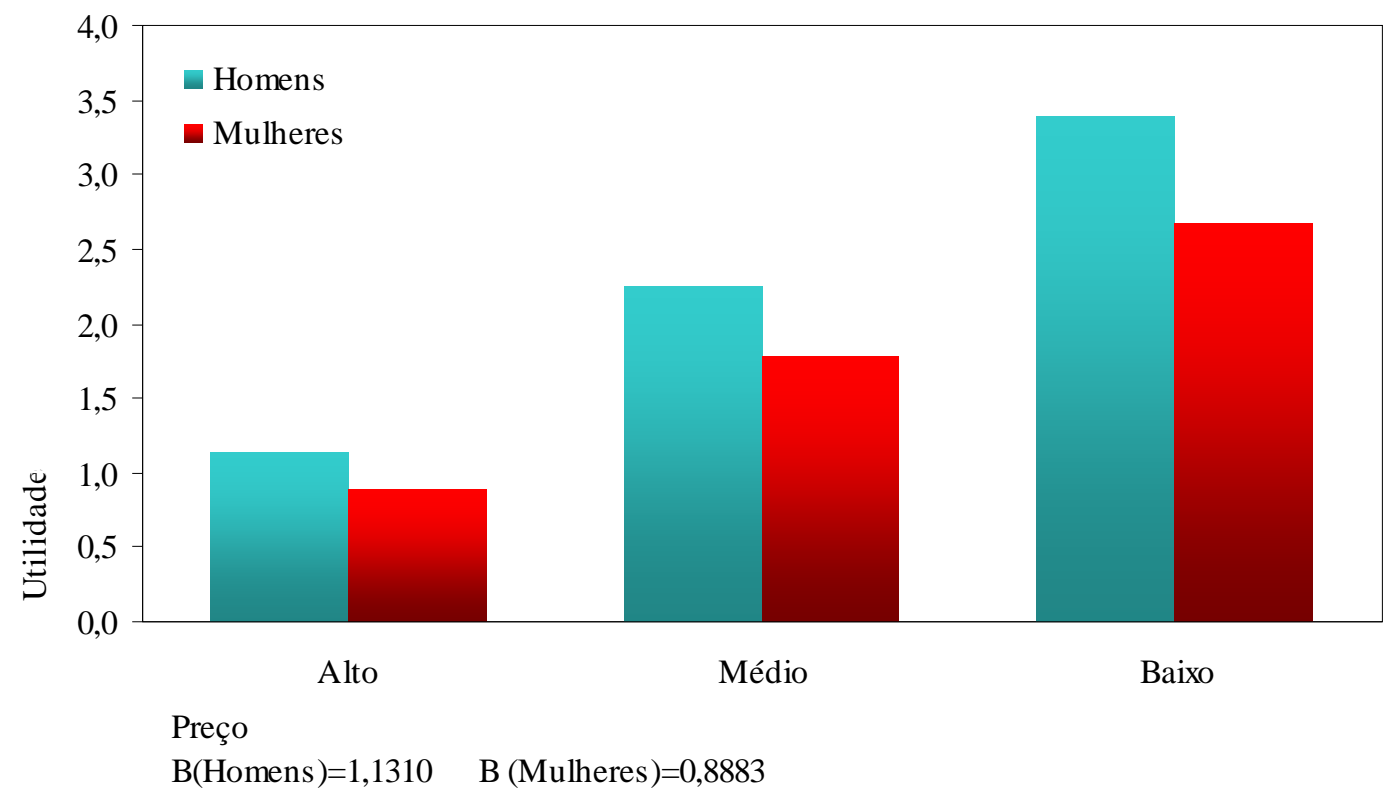


Assim, conforme resultados apresentados, o atributo mais importante para os homens e mulheres da amostra na hora de avaliar camisetas é a qualidade, seguido pelo tipo de marca e preço. A camiseta preferida por ambos os sexos é a que apresenta marca genérica, que não exibe nenhum signo aparente, qualidade alta e preço baixo, sendo essas duas últimas características coerentes com o tipo de marca preferido, pois as marcas genéricas concorrem por meio do oferecimento de produtos com a melhor qualidade a um determinado preço. E, o grupo feminino aparenta ser menos sensível ao preço.

Por fim, para testar a capacidade de previsão do modelo de preferência dos homens e mulheres da amostra avaliou-se a escolha entre as duas camisetas criadas para simulação. A versão que possui marca social (modelo Y), preço baixo e qualidade alta é a predileta por ambos os sexos, visto que, dessa composição, somente o tipo de marca não é o preferido. Entre os homens esse produto teve maior aceitação, visto que eles são menos preocupados com o tipo de marca e, desse modo, a aversão deles à social é menor do que a das mulheres.

Embora apresentasse o tipo de marca e o nível de preço preferido pelos homens e mulheres da amostra, a outra opção simulada não foi muito escolhida, pois possuía um menor nível de qualidade em relação ao produto predileto, aspecto esse que teve maior peso na preferência dos respondentes do que a marca genérica. A tabela 16 apresenta os percentuais de preferência de cada camiseta simulada segundo os métodos de previsão de escolha utilidade máxima, BTL e Logit.

Tabela 16: Preferência dos homens e mulheres da amostra pelos dois estímulos de simulação

\begin{tabular}{|c|c|c|c|c|}
\hline & Produto simulado & Utilidade máxima & BTL & Logit \\
\hline \multirow{2}{*}{$\begin{array}{l}\tilde{\Xi} \\
\text { : } \\
\text { : }\end{array}$} & Camiseta modelo X, preço baixo, qualidade média & $16,07 \%$ & $43,81 \%$ & $23,98 \%$ \\
\hline & Camiseta modelo Y, preço baixo, qualidade alta & $83,93 \%$ & $56,19 \%$ & $76,02 \%$ \\
\hline \multirow{2}{*}{ 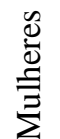 } & Camiseta modelo X, preço baixo, qualidade média & $35,16 \%$ & $46,25 \%$ & $36,08 \%$ \\
\hline & Camiseta modelo Y, preço baixo, qualidade alta & $64,84 \%$ & $53,75 \%$ & $63,92 \%$ \\
\hline
\end{tabular}

Modelo de camiseta: X: Sem estampas; Y: Possui o símbolo de uma famosa causa social estampado na frente.

\subsection{Análise dos segmentos de consumidores}

A segmentação dos respondentes apoiou-se nos valores de utilidade atribuídos por eles aos três tipos de marca e aos fatores qualidade e preço, todos obtidos após realização da 
análise conjunta sobre as escolhas da amostra. Como o modelo de preferência da amostra considerado no estudo foi gerado com base na opinião de 184 casos, essas foram as observações processadas na análise de conglomerados.

O processo hierárquico de aglomeração resultou em seis conglomerados com coeficiente de variância (ou heterogeneidade) igual a 6,772, visto que soluções mais compactas apresentavam grande aumento desse indicador, como mostrado no apêndice 3. Essa solução, contudo, possuía má distribuição dos casos entre os grupos, uma vez que um deles concentrou 122 pessoas enquanto os demais tinham 19, 16, 16, 8 e 3 observações.

Para melhorar essa solução, executou-se a aglomeração não-hierárquica objetivandose a criação de seis grupos. Os centróides iniciais de cada variável para cada conglomerado, exibidos na tabela 17, foram calculados por meio da média aritmética dos valores $\mathrm{Z}$ delas para os casos contidos em cada grupo gerado no processo hierárquico. A divisão otimizada da amostra resultou em uma distribuição muito boa de pessoas entre os grupos, sendo que a composição deles agora era de 55, 33, 14, 19, 16, e 47 casos.

Tabela 17: Centróides iniciais utilizados no agrupamento não-hierárquico

\begin{tabular}{|c|c|c|c|c|c|}
\hline Grupos & $\begin{array}{c}\text { Marca } \\
\text { Genérica }\end{array}$ & Marca Social & $\begin{array}{c}\text { Marca de } \\
\text { Fabricante }\end{array}$ & Qualidade & Preço \\
\hline 1 & $-0,08991$ & 0,13070 & $-0,02694$ & $-0,56294$ & 0,06946 \\
\hline 2 & 1,79708 & $-0,43332$ & $-1,46842$ & 0,98310 & $-0,75129$ \\
\hline 3 & $-0,50408$ & 0,09763 & 0,43392 & 1,34819 & 2,26850 \\
\hline 4 & $-1,71537$ & 1,25287 & 0,62873 & 0,68816 & $-0,13394$ \\
\hline 5 & 0,54859 & $-2,22912$ & 1,48289 & 1,50349 & $-0,44485$ \\
\hline 6 & $-0,15799$ & 2,37556 & $-2,02365$ & 1,38270 & $-1,02897$ \\
\hline
\end{tabular}

Sobre as variáveis utilizadas para o processo de agrupamento, de acordo com a tabela 18, para todas foi possível rejeitar a hipótese nula do teste $\mathrm{F}$, a qual estabelece que a média da variável é igual nos grupos, e, portanto, elas são úteis para discriminar os grupos. Observa-se que a utilidade da qualidade é a que possui maior poder discriminatório, enquanto que a preferência pela marca social é a que possui o menor.

Tabela 18: Resultado do teste $F$ para as variáveis de aglomeração

\begin{tabular}{|l|c|c|}
\hline \multicolumn{1}{|c|}{ Variável } & F & Sig. \\
\hline Valor Z: Marca Genérica & 89,590 & 0,000 \\
\hline Valor Z: Marca Social & 50,350 & 0,000 \\
\hline Valor Z: Marca de Fabricante & 80,523 & 0,000 \\
\hline Valor Z: Qualidade & 97,639 & 0,000 \\
\hline Valor Z: Preço & 86,101 & 0,000 \\
\hline
\end{tabular}


Analisando-se os seis grupos formados após o agrupamento não-hierárquico, é possível descrevê-los por meio de seus valores médios de utilidade, os quais são mostrados na tabela 19. Como já dito anteriormente na apresentação dos resultados sobre a predileção dos respondentes pelos fatores estudados, os valores negativos da utilidade média dos grupos conferidos ao fator qualidade são decorrentes do modo como o relacionamento dos níveis desse atributo foi estabelecido durante a análise conjunta e, dessa forma, esses números não indicam aversão a ele. Assim, na análise do fator qualidade, é importante observar o impacto que o seu valor médio de utilidade tem na equação de preferência do grupo, sendo que quanto maior é a magnitude desse número, mais importante é a qualidade (e, consequentemente, o seu nível alto) para o agrupamento.

Tabela 19: Características dos grupos de respondentes

\begin{tabular}{|c|c|c|c|c|c|c|}
\hline \multirow{2}{*}{ Grupos } & \multirow{2}{*}{$\begin{array}{c}\text { Número de } \\
\text { pessoas }\end{array}$} & $\begin{array}{c}\text { Marca } \\
\text { Genérica }\end{array}$ & $\begin{array}{c}\text { Marca } \\
\text { Social }\end{array}$ & $\begin{array}{c}\text { Marca de } \\
\text { Fabricante }\end{array}$ & Qualidade & Preço \\
\hline Social exigente & 55 & $-0,1152$ & 0,3758 & $-0,2606$ & $-2,2485$ & 1,5424 \\
\hline $\begin{array}{c}\text { Anti-social de } \\
\text { qualidade }\end{array}$ & 47 & 0,2057 & $-0,2766$ & 0,0709 & $-2,6135$ & 0,5000 \\
\hline $\begin{array}{c}\text { Genérico de } \\
\text { qualidade }\end{array}$ & 33 & 2,2020 & 0,0606 & $-2,2626$ & $-1,2879$ & 0,4495 \\
\hline $\begin{array}{c}\text { Sócio-fabricante } \\
\text { exigente }\end{array}$ & 19 & $-2,2982$ & 1,2105 & 1,0877 & $-1,3333$ & 1,1228 \\
\hline $\begin{array}{c}\text { Barganhador } \\
\text { anti-social }\end{array}$ & 16 & 1,0208 & $-2,8958$ & 1,8750 & $-0,6250$ & 0,7083 \\
\hline $\begin{array}{c}\text { Barganhador } \\
\text { social }\end{array}$ & 14 & $-0,4762$ & 0,4286 & 0,0476 & $-0,9524$ & 2,4881 \\
\hline
\end{tabular}

Para um grupo ser classificado em termos das marcas preferidas, observou-se a diferença dos valores de utilidade entre os três tipos de marca e a possível existência de aversão a um deles. Já, sobre os fatores qualidade e preço, para serem considerados importantes para a preferência do grupo por uma camiseta, estabeleceu-se que o primeiro precisava ter uma utilidade média menor do que -1 , enquanto o segundo necessitava de um valor maior do que 0,5 .

O conglomerado denominado social exigente é o maior e caracteriza-se por pessoas que gostam da marca social e têm aversão aos outros dois tipos e são altamente demandantes em termos de proposta de valor tangível, pois exigem alta qualidade por um baixo preço. Assim, esse grupo tende a ser sensível ao preço e pode apresentar lealdade a marcas que tenham relacionamento com causas sócio-ambientais, transmitam a sensação de qualidade e não sejam demasiadamente caras. 
O conjunto denominado anti-social de qualidade é o segundo em termos de número de pessoas, as quais se caracterizam pela predileção de marcas que não tenham cunho social, alta exigência em termos de qualidade e baixa sensibilidade ao preço, o que sugere a possibilidade de se cobrar preço diferenciado caso se consiga desenvolver uma marca de fabricante que agrade esses respondentes e gere um vínculo a ela, embora seja difícil, dada a maior preferência deles pela marca genérica e a quase indiferença pela de fabricante.

Observando-se o agrupamento intitulado genérico de qualidade, percebem-se algumas semelhanças com o anti-social de qualidade, como uma grande exigência de qualidade da camiseta e uma baixa sensibilidade ao seu preço; porém, o que os diferencia é que o genérico de qualidade tem elevada preferência pelo tipo genérico de marca de camiseta, indiferença pelo social e aversão ao de fabricante. Assim, como é difícil criar um vínculo perene com esses respondentes, visto a escolha deles pela marca genérica, entende-se que há menor possibilidade de se aproveitar a baixa sensibilidade ao preço para se cobrar um valor acima do mercado, sendo que uma das únicas oportunidades para isso é por meio do oferecimento de provas concretas que o produto possui qualidade maior do que os concorrentes e, portanto, preço maior.

Os sócio-fabricante exigentes são as pessoas que preferem produtos com marca, tanto social quanto de fabricante, têm aversão à marca genérica e gostam de produtos de alta qualidade e preço baixo. Assim, esse grupo tende a ser sensível ao preço e pode apresentar lealdade a marcas que tenham relacionamento com causas sócio-ambientais ou possuam alto reconhecimento no mundo da moda, transmitam a sensação de qualidade e não sejam demasiadamente caras, ou seja, é necessário oferecer uma proposta de valor vantajosa, com benefícios tangíveis e abstratos, para convencê-los a pagar um preço maior do que o aplicado pelos concorrentes.

Por fim, os grupos barganhador anti-social e barganhador social são semelhantes ao não se importarem em demasia com a qualidade e sim com o preço; porém, diferem ao escolher o tipo de marca, sendo que o primeiro prefere o tipo de marca genérica e de fabricante (sendo essa última a predileta) e tem aversão ao social, enquanto que o segundo tem preferência pela opção de marca social, indiferença pela de fabricante e não gosta da genérica. É possível criar fortes vínculos com essas classes de respondente, porém, a cobrança de preço diferenciado por um produto é difícil, visto a sensibilidade deles ao valor da mercadoria, e, desse modo, é necessário oferecer uma proposta de valor vantajosa, com benefícios tangíveis e abstratos, para convencêlos a pagar um preço maior do que o aplicado pelos concorrentes.

Essas características sugerem que os barganhadores anti-sociais poderiam ser vistos como comprando em promoções de camisetas, com marca, principalmente, ou sem; já os 
sociais seriam pessoas que gostam de liquidações, pontas de estoque e outlets de camisetas de marca de fabricante ou social.

Em resumo, observa-se que os seis grupos formados realmente possuem características que os tornam únicos entre si, demonstrando que há demanda para diferentes tipos de marcas e que a relação com elas varia entre os diferentes segmentos, sendo que em alguns deles podese desfrutar de fidelidade e insensibilidade aos preços ou qualidade por parte do consumidor e em outros não.

\subsection{Diferencial de preço atribuído aos tipos de marca}

A marca é um valor agregado, ela revela o invisível, o impalpável, que se esconde sob os valores materiais. São valores agregados pelos quais o comprador está disposto a pagar (KAPFERER, 2004). Razão pela qual, aliás, às vezes se avalia o valor financeiro de uma marca medindo-se o ágio associado a ela, o qual é a diferença entre o preço que o consumidor está disposto a pagar para adquirir um produto dela e o de um produto idêntico, mas genérico ou de uma marca desconhecida (ELLWOOD, 2004; KAPFERER, 2004: 24).

Assim, uma forma importante de se medir a apreciação por uma marca é o preço adicional que os consumidores estariam dispostos a pagar para continuarem comprando-a (D’EMIDIO, 2009). Para essa análise, utilizaram-se as opiniões dos 248 respondentes pertencentes à amostra válida deste estudo. Durante a coleta de dados, pediu-se para eles escreverem o valor que pagariam por uma camiseta branca de manga curta e qualidade média de cada tipo de marca estudado. Com base nesses dados, executou-se o teste t para amostras relacionadas a fim de se verificar, ao nível de erro de 1,67\%, se a média de preço de cada tipo de camiseta é estatisticamente diferente.

Tabela 20: Medidas de dispersão e posição dos preços das camisetas atribuídos pela amostra

\begin{tabular}{|c|c|c|c|c|c|}
\hline Tipo de Marca & Mínimo & Máximo & Mediana & Média & Desvio-Padrão \\
\hline Genérica & 1,00 & 100,00 & 20,00 & 23,67 & 11,79 \\
\hline Social & 0,00 & 90,00 & 26,50 & 29,53 & 14,95 \\
\hline Fabricante & 1,50 & 100,00 & 35,00 & 37,20 & 18,89 \\
\hline
\end{tabular}

Como exibido na tabela 20, as três marcas possuem valores máximos e mínimos muito próximos, sendo que o maior preço é visto na genérica e na de fabricante ( $\mathrm{R} \$ 100,00$, ambas) e o menor é constatado na social ( $\mathrm{R} \$ 0,00$, ou seja, só aceitaria a camiseta se fosse sem custo). O desvio-padrão que é alto, representando aproximadamente 50\% da média dos preços para cada 
tipo de marca. Tentou-se reduzir essa variabilidade por meio da exclusão de alguns possíveis outliers; contudo, como a redução na dispersão foi pouca, decidiu-se conservar todos os casos e assumir que essa alta variância nas respostas reflete a diversidade de opiniões dos participantes.

Em relação ao teste t para amostras relacionadas realizado com as médias de preços dos três tipos de marca, conforme os valores apresentados na tabela 21, rejeita-se, ao nível de erro de $1,67 \%$, a hipótese nula, ou seja, há indícios estatísticos de que as três médias são diferentes. Assim, é possível afirmar que, na opinião da amostra, camisetas com marca de fabricante, em média, são as mais valiosas, seguidas pela social e genérica, sugerindo-se que o investimento no desenvolvimento do patrimônio de uma marca possibilita que a de fabricante e a social consigam aplicar, em média, preços diferenciados em relação à genérica (57\% e $25 \%$ a mais, respectivamente), sendo que, por trabalhar com muitas propagandas e associar-se ao mercado da moda e, às vezes, de luxo, a de fabricante consegue desfrutar de um diferencial maior do que a social.

Tabela 21: Teste t das médias dos preços das camisetas atribuídos pela amostra

\begin{tabular}{|c|c|c|}
\hline Marcas relacionadas & t & Sig. (bicaudal) \\
\hline Genérica/Social & $-8,498$ & 0,000 \\
\hline Genérica/Fabricante & $-13,044$ & 0,000 \\
\hline Social/Fabricante & $-8,523$ & 0,000 \\
\hline
\end{tabular}

Tabela 22: Medidas de dispersão e posição dos preços das camisetas atribuídos pela amostra segundo gênero sexual

\begin{tabular}{|c|c|c|c|c|c|c|}
\hline Gênero sexual & Tipo de Marca & Mínimo & Máximo & Mediana & Média & Desvio-Padrão \\
\hline \multirow{3}{*}{ Masculino } & Genérica & 1,00 & 100,00 & 20,00 & 23,01 & 12,55 \\
\cline { 2 - 7 } & Social & 7,50 & 90,00 & 25,00 & 28,62 & 14,65 \\
\cline { 2 - 7 } & Fabricante & 1,50 & 100,00 & 35,00 & 37,28 & 19,48 \\
\hline \multirow{3}{*}{ Feminino } & Genérica & 5,00 & 50,00 & 20,00 & 24,31 & 11,01 \\
\cline { 2 - 7 } & Social & 0,00 & 75,00 & 30,00 & 30,43 & 15,23 \\
\cline { 2 - 7 } & Fabricante & 7,00 & 90,00 & 35,00 & 37,13 & 18,37 \\
\hline
\end{tabular}

Avaliando as médias de preço dos tipos de marca por gênero sexual, os dados apresentados na tabela 22 mostram que os homens atribuem os preços máximos mais altos para os três tipos de camiseta e, também, os mínimos mais baixos para a genérica e de fabricante, restando às mulheres o preço mais baixo para a social. Porém, em termos de média e mediana, as mulheres possuem valores maiores do que os homens para as marcas genérica e social, ou seja, embora não atribuam preços extremos, os valores citados por elas estão em média em um patamar mais alto do que os pensados pelos homens, sendo que isso é comprovado pelo desviopadrão relativo à média, o qual é mais alto para os respondentes do sexo masculino (variando de 
51\% da média da marca social a 54\% para a genérica) do que para os do feminino (variando de 45,3\% da média da marca genérica a 50\% no caso da social). É interessante notar que a maior diferença entre as médias e as medianas de preços entre homens e mulheres reside na marca social, sendo que o primeiro grupo atribui preço menor do que o último.

Conforme exibido na tabela 23, ao nível de erro de 1,67\%, rejeita-se a hipótese nula do teste t para amostras relacionadas das médias de preços dos três tipos de marca, ou seja, há indícios estatísticos de que elas são diferentes tanto para homens quanto para mulheres. Assim, é possível afirmar que, na opinião de ambos os sexos, camisetas com marca de fabricante são, em média, as mais valiosas, seguidas pela social e genérica, sugerindo-se, semelhantemente à amostra como um todo, que o investimento no desenvolvimento do patrimônio de uma marca possibilita que a de fabricante e a social consigam aplicar, em média, preços diferenciados em relação à genérica (62\% e 24\% a mais, respectivamente, para os homens e $53 \%$ e $25 \%$, na mesma ordem, para as mulheres).

E, observa-se que os homens atribuem, em média, preços menores do que as mulheres, mostrando, desse modo, uma maior exigência deles em relação ao fator preço das marcas (igualmente ao encontrado no modelo de preferência gerado pela análise conjunta para um grupo menor de respondentes do sexo masculino e feminino), além de considerarem um diferencial de preço maior da marca de fabricante em relação à social quando comparado com as mulheres.

Tabela 23: Teste t das médias dos preços das camisetas atribuídos pela amostra segundo gênero sexual

\begin{tabular}{|c|c|c|c|}
\hline Gênero sexual & Marcas relacionadas & t & Sig. (bicaudal) \\
\hline \multirow{3}{*}{ Homens } & Genérica/Social & $-5,502$ & 0,000 \\
\cline { 2 - 4 } & Genérica/Fabricante & $-8,750$ & 0,000 \\
\cline { 2 - 4 } & Social/Fabricante & $-6,206$ & 0,000 \\
\hline \multirow{3}{*}{ Mulheres } & Genérica/Social & $-6,254$ & 0,000 \\
\cline { 2 - 4 } & Genérica/Fabricante & $-9,873$ & 0,000 \\
\cline { 2 - 4 } & Social/Fabricante & $-5,865$ & 0,000 \\
\hline
\end{tabular}

Já, analisando as médias de preço dos tipos de marca por preferência declarada a elas, os dados apresentados na tabela 24 mostram que os respondentes que declararam preferir a marca genérica e de fabricante atribuem os preços máximos mais altos para as camisetas que possuem os respectivos tipos de marca; porém, isso não ocorre no caso da marca social, sendo atribuído o preço máximo desse tipo de camiseta pelo grupo que prefere a marca genérica. Para os três aglomerados, a marca de fabricante apresenta o maior preço mínimo em relação às outras duas opções. 
Em termos de média e mediana, a marca de fabricante e a genérica sempre possuem os maiores e menores valores, respectivamente, não importando o grupo de respondentes. Diferente do esperado, somente a marca social e de fabricante apresentam os maiores valores de média e mediana entre os respondentes que preferem os respectivos tipos de marca, faltando o mesmo ocorrer com a marca genérica. E, em relação ao desvio-padrão, constata-se que ele é alto (coeficiente de variação, o qual é o desvio-padrão em relação à média, entre 46\% e 57\%, inclusive); contudo, assume-se que essa alta variância nas respostas reflete a diversidade de opiniões dos participantes.

Tabela 24: Medidas de dispersão e posição dos preços das camisetas atribuídos pela amostra segundo preferência declarada de tipo de marca

\begin{tabular}{|c|c|c|c|c|c|c|}
\hline Preferência & Tipo de Marca & Mínimo & Máximo & Mediana & Média & Desvio-Padrão \\
\hline \multirow{4}{*}{ Genérica } & Genérica & 1,00 & 100,00 & 20,00 & 23,68 & 12,60 \\
\cline { 2 - 7 } & Social & 10,00 & 90,00 & 25,00 & 27,95 & 13,05 \\
\cline { 2 - 7 } & Fabricante & 1,50 & 80,00 & 35,00 & 34,08 & 16,24 \\
\hline \multirow{3}{*}{ Fabricante } & Genérica & 5,00 & 55,00 & 20,00 & 22,82 & 11,37 \\
\cline { 2 - 7 } & Social & 0,00 & 80,00 & 25,00 & 27,06 & 15,39 \\
\cline { 2 - 7 } & Fabricante & 7,00 & 100,00 & 40,00 & 42,79 & 20,30 \\
\hline \multirow{3}{*}{ Social } & Genérica & 5,00 & 50,00 & 20,00 & 24,43 & 11,26 \\
\cline { 2 - 7 } & Social & 5,00 & 75,00 & 30,00 & 33,60 & 15,91 \\
\cline { 2 - 7 } & Fabricante & 7,00 & 100,00 & 30,00 & 35,80 & 19,55 \\
\hline
\end{tabular}

De acordo o apresentado na tabela 25, ao nível de erro de 1,67\%, rejeita-se a hipótese nula do teste t para amostras relacionadas das médias de preços dos três tipos de marca, exceto na comparação entre a marca social e de fabricante para o grupo que prefere a social, pois, nesse caso, a significância do teste (13,8\%) foi maior do que o limiar de rejeição, definido como 1,67\%.

Tabela 25: Teste $t$ das médias dos preços das camisetas atribuídos pela amostra segundo preferência declarada de tipo de marca

\begin{tabular}{|c|c|c|c|}
\hline Preferência & Marcas relacionadas & t & Sig. (bicaudal) \\
\hline \multirow{3}{*}{ Genérica } & Genérica/Social & $-4,054$ & 0,000 \\
\cline { 2 - 4 } & Genérica/Fabricante & $-7,024$ & 0,000 \\
\cline { 2 - 4 } & Social/Fabricante & $-4,731$ & 0,000 \\
\hline \multirow{3}{*}{ Fabricante } & Genérica/Social & $-3,143$ & 0,002 \\
\cline { 2 - 4 } & Genérica/Fabricante & $-10,132$ & 0,000 \\
\cline { 2 - 4 } & Social/Fabricante & $-9,775$ & 0,000 \\
\hline \multirow{3}{*}{ Social } & Genérica/Social & $-7,977$ & 0,000 \\
\cline { 2 - 4 } & Genérica/Fabricante & $-6,166$ & 0,000 \\
\cline { 2 - 4 } & Social/Fabricante & $-1,498$ & 0,138 \\
\hline
\end{tabular}

Assim, para os optantes pela marca genérica e de fabricante, há indícios estatísticos de que as médias de preços dos três tipos de marca são diferentes. Para eles, camisetas com 
marca de fabricante são, em média, as mais valiosas, seguidas pela social e genérica, sugerindo-se, novamente, que o investimento no desenvolvimento do patrimônio de uma marca possibilita que a de fabricante e a social consigam aplicar, em média, preços diferenciados em relação à genérica (44\% e 18\% a mais, respectivamente, para os optantes pela marca genérica e $88 \%$ e 19\%, na mesma ordem, para os que preferem a de fabricante).

É interessante citar que para o grupo que prefere a marca de fabricante, a diferença da média de preços entre a camiseta que a possui e a de marca social é maior, muito devido ao valor mais alto atribuído à de marca de fabricante e, em parte, ao menor apreço desse grupo pela camiseta de marca social, visto o menor preço mínimo e média de preços em relação aos demais conjuntos de respondentes, o que é coerente com o modelo de preferência gerado por intermédio da análise conjunta para um agrupamento mais reduzido de optantes pela marca de fabricante e com a observação de Ellwood (2004) de que respondentes que preferem esse tipo de marca desejam se agradar sem ficar com a consciência culpada e, desse modo, associam a marca social a grupos com estilo de vida indesejáveis.

Já para os que preferem a marca social, há indícios estatísticos de que a média de preços da marca genérica é diferente das demais, mas o mesmo não ocorre entre a social e a de fabricante. Portanto, camisetas com marca de fabricante e social possuem estatisticamente igual diferencial de valor, em média, quando comparadas com as genéricas, sugerindo-se que o investimento no desenvolvimento do patrimônio de qualquer um desses dois tipos de marca pode agregar, estatisticamente, o mesmo diferencial de valor para um produto em relação a uma versão genérica. O adicional da média de preço da marca de fabricante e da social é, nessa mesma ordem, 47\% e 38\% maior em relação à genérica, sendo que esse é o grupo onde a marca social apresenta a maior percepção de valor.

Portanto, conforme apresentado, na opinião da amostra, o investimento no patrimônio de uma marca gera maiores ganhos para uma empresa por meio da possibilidade de se aplicar preço diferenciado em relação a uma versão genérica do produto, sendo que as marcas de fabricante são as que desfrutam de maior percepção de valor. É interessante agora avaliar a sensibilidade de preço desses respondentes diante da necessidade de se consumir mais uma unidade de cada tipo de marca.

\subsection{Fidelidade aos tipos de marca}

Para a análise da fidelidade aos tipos de marca estudados, utilizaram-se as opiniões dos 248 respondentes pertencentes à amostra válida deste estudo. Durante a coleta de dados, 
pediu-se para eles escreverem o valor que pagariam por uma camiseta branca de manga curta e qualidade média de cada tipo de marca estudado e, posteriormente, que registrassem o valor unitário que pagariam por duas camisetas com essas mesmas características, mas com cores diferentes, de cada um dos três modelos avaliados. Com base nesses dados, calculou-se a elasticidade-preço da demanda dos tipos de marca para cada respondente e executou-se o teste t para amostras relacionadas a fim de se verificar, ao nível de erro de 1,67\%, se a média da elasticidade-preço da demanda para cada tipo de camiseta é estatisticamente diferente. As medidas de dispersão e posição da elasticidade-preço da demanda estão em módulo, pois, para a análise desse indicador, o que interessa é a sua magnitude.

Como exibido na tabela 26, as três marcas possuem valores mínimos de elasticidade igual a zero, ou seja, alguns respondentes apresentam demanda infinitamente inelástica diante da necessidade de se comprar mais uma camiseta da mesma marca, mas de cor diferente. Em relação aos valores máximos, percebe-se que a marca de fabricante apresenta a maior elasticidade, talvez devido ao seu alto preço, o que exigiria um desconto maior para aumentar para dois o número de camisetas compradas. Devido à alta variabilidade dos dados, o coeficiente de variação (desviopadrão em relação à média) é maior do que $118 \%$ nos três casos, a média e mediana dos preços das camisetas de cada marca são bem diferentes. Decidiu-se não promover a redução dessa variância por meio de exclusões de respondentes da amostra estudada e assumiu-se que essa alta dispersão nas respostas reflete a diversidade de opiniões dos participantes.

Tabela 26: Medidas de dispersão e posição das elasticidades-preço da demanda segundo a amostra

\begin{tabular}{|c|c|c|c|c|c|}
\hline Tipo de Marca & Mínimo & Máximo & Mediana & Média & Desvio-Padrão \\
\hline Genérica & 0,00 & 9,67 & 1,00 & 1,37 & 1,75 \\
\hline Social & 0,00 & 9,67 & 1,2 & 1,63 & 1,94 \\
\hline Fabricante & 0,00 & 14,67 & 1,33 & 1,84 & 2,33 \\
\hline
\end{tabular}

Em relação ao teste t para amostras relacionadas das médias de elasticidades-preço da demanda dos três tipos de marca, conforme os valores apresentados na tabela 27, rejeita-se, ao nível de erro de 1,67\%, a hipótese nula somente para a comparação entre a marca genérica e de fabricante.

Assim, há indícios estatísticos de que a média das elasticidades-preço da demanda da marca genérica é diferente da de fabricante, mas o mesmo não ocorre entre a social e as outras duas. Portanto, marca de fabricante para camisetas possui, em média, menor fidelidade do que a marca genérica. Essa constatação é diferente do que estabelece a teoria, pois, por ser um produto com baixa diferenciação e, desse modo, com um maior número de substitutos, era esperado que a 
demanda pela camiseta de marca genérica fosse mais elástica (LAMBIN, 2000). Contudo, a maior fidelidade a esse tipo de marca converge com a estrutura de preferência da amostra, gerada pela análise conjunta, que apontava a marca genérica como a predileta pelos respondentes.

Essa menor fidelidade à marca de fabricante, que possui em média maior diferencial de preço (conforme exibido anteriormente), pode ter ocorrido devido ao modo como os dados foram coletados, pois, ao solicitar que o respondente determinasse quanto deveria ser o preço unitário de uma camiseta de cada tipo de marca a fim de se adquirirem duas semelhantes, ele exigiria uma redução de preço maior no caso das marcas mais caras, pois, devido ao alto valor, ele não teria interesse em comprar mais outra unidade parecida. Esse entendimento é sustentado por Lambin (2000), que afirma que a sensibilidade dos consumidores ao preço é maior quando ele é mais alto e vice-versa. Se fosse apresentada a possibilidade de comprar outra unidade que tivesse maior diferenciação, talvez os resultados fossem outros.

Já as marcas sociais para camisetas possuem, estatisticamente, igual fidelidade em relação às genéricas e de fabricante, sugerindo que embora tenham oportunidade para desfrutar de preço diferenciado, as marcas sociais possuem uma fidelidade do consumidor que pode ser tão alta quanto à da marca genérica ou igualmente baixa como a da marca de fabricante, sendo que essa definição provavelmente vai depender do posicionamento da marca, da causa apoiada e do segmento de consumidores alvejado.

Tabela 27: Teste t das médias das elasticidades-preço da demanda segundo a amostra

\begin{tabular}{|c|c|c|}
\hline Marcas relacionadas & t & Sig. (bicaudal) \\
\hline Genérica/Social & 2,342 & 0,020 \\
\hline Genérica/Fabricante & 3,746 & 0,000 \\
\hline Social/Fabricante & 1,908 & 0,058 \\
\hline
\end{tabular}

Avaliando as médias das elasticidades-preço da demanda por gênero sexual, os dados apresentados na tabela 28 mostram que tanto os homens quanto as mulheres possuem o valor mínimo igual a zero para todos os tipos de marca, ou seja, existe um ou mais respondentes de ambos os sexos que apresentam demanda infinitamente inelástica diante da necessidade de se comprar mais uma camiseta da mesma marca, mas de cor diferente. Em relação aos valores máximos, percebe-se que a marca de fabricante apresenta a maior elasticidade para ambos os sexos, talvez devido ao seu alto preço, o que exigiria um desconto maior para aumentar para dois o número de camisetas compradas. Devido à alta variabilidade dos dados, o coeficiente de variação é maior do que $115 \%$ nas três marcas para ambos os sexos, a média e mediana dos preços das camisetas de cada marca são bem diferentes. 
Tabela 28: Medidas de dispersão e posição das elasticidades-preço da demanda segundo gênero sexual da amostra

\begin{tabular}{|c|c|c|c|c|c|c|}
\hline Gênero sexual & Tipo de Marca & Mínimo & Máximo & Mediana & Média & Desvio-Padrão \\
\hline \multirow{3}{*}{ Masculino } & Genérica & 0,00 & 9,67 & 0,00 & 1,39 & 1,90 \\
\cline { 2 - 7 } & Social & 0,00 & 8,33 & 1,17 & 1,55 & 1,91 \\
\cline { 2 - 7 } & Fabricante & 0,00 & 11,89 & 1,13 & 1,94 & 2,48 \\
\hline \multirow{3}{*}{ Feminino } & Genérica & 0,00 & 6,33 & 1,00 & 1,35 & 1,60 \\
\cline { 2 - 7 } & Social & 0,00 & 9,67 & 1,30 & 1,71 & 1,98 \\
\cline { 2 - 7 } & Fabricante & 0,00 & 14,67 & 1,33 & 1,75 & 2,17 \\
\hline
\end{tabular}

Em relação ao teste t para amostras relacionadas das médias de elasticidades-preço da demanda dos três tipos de marca, conforme os valores apresentados na tabela 29, rejeita-se, ao nível de erro de 1,67\%, a hipótese nula, exceto na comparação entre a marca social e de fabricante, para as mulheres, e entre a social e as outras duas, para os homens, pois, nesses casos, a significância do teste foi maior do que o limiar de rejeição, definido como 1,67\%. Assim, excetuando-se essas três comparações, há indícios estatísticos de que as médias das elasticidades-preço da demanda das marcas são diferentes.

Portanto, para os homens, a marca genérica de camiseta possui maior fidelidade, em média, do que a marca de fabricante. E, a marca social possui uma medida média de fidelidade que não é possível distinguir, estatisticamente, se é maior ou menor do que a das demais. Já para as mulheres, marcas de camisetas de fabricante e social possuem, estatisticamente, igual fidelidade por parte dos respondentes, sendo elas em média menores do que a da marca genérica.

Tabela 29: Teste t das médias das elasticidades-preço da demanda segundo gênero sexual da amostra

\begin{tabular}{|c|c|c|c|}
\hline Gênero sexual & Marcas relacionadas & t & Sig. (bicaudal) \\
\hline \multirow{3}{*}{ Homens } & Genérica/Social & 0,905 & 0,367 \\
\cline { 2 - 4 } & Genérica/Fabricante & 2,713 & 0,008 \\
\cline { 2 - 4 } & Social/Fabricante & 2,050 & 0,043 \\
\hline \multirow{3}{*}{ Mulheres } & Genérica/Social & 2,594 & 0,011 \\
\cline { 2 - 4 } & Genérica/Fabricante & 2,607 & 0,010 \\
\cline { 2 - 4 } & Social/Fabricante & 0,318 & 0,751 \\
\hline
\end{tabular}

Analisando as médias das elasticidades-preço da demanda por preferência declarada aos tipos de marca, de acordo com o exibido na tabela 30, todos os grupos possuem o valor mínimo igual a zero, ou seja, possuem um ou mais respondentes que apresentam demanda infinitamente inelástica diante da necessidade de se comprar mais uma camiseta da mesma marca, mas de cor diferente; e os três agrupamentos têm a marca de fabricante com o maior valor máximo de elasticidade. Observa-se, também, que o valor máximo de elasticidade de uma marca é menor 
no seu respectivo grupo de preferência, exceto no caso da marca social, cujo menor valor máximo ocorreu no grupo optante pela marca genérica. Devido à alta variabilidade dos dados, o coeficiente de variação é igual ou maior do que $100 \%$ nas três marcas para todos os grupos de preferência, a média e mediana dos preços das camisetas de cada marca são bastante diferentes.

Tabela 30: Medidas de dispersão e posição das elasticidades-preço da demanda segundo preferência declarada de tipo de marca da amostra

\begin{tabular}{|c|c|c|c|c|c|c|}
\hline Preferência & Tipo de Marca & Mínimo & Máximo & Mediana & Média & Desvio-Padrão \\
\hline \multirow{3}{*}{ Genérica } & Genérica & 0,00 & 6,33 & 0,00 & 1,10 & 1,46 \\
\cline { 2 - 7 } & Social & 0,00 & 7,67 & 0,89 & 1,33 & 1,74 \\
\cline { 2 - 7 } & Fabricante & 0,00 & 11,89 & 0,87 & 1,65 & 2,30 \\
\hline \multirow{3}{*}{ Fabricante } & Genérica & 0,00 & 9,67 & 0,00 & 1,20 & 1,82 \\
\cline { 2 - 7 } & Social & 0,00 & 8,33 & 1,18 & 1,47 & 1,86 \\
\cline { 2 - 7 } & Fabricante & 0,00 & 9,67 & 1,31 & 1,64 & 2,02 \\
\hline \multirow{3}{*}{ Social } & Genérica & 0,00 & 7,67 & 1,60 & 1,84 & 1,91 \\
\cline { 2 - 7 } & Social & 0,00 & 9,67 & 1,89 & 2,14 & 2,14 \\
\cline { 2 - 7 } & Fabricante & 0,00 & 14,67 & 1,56 & 2,26 & 2,57 \\
\hline
\end{tabular}

Em relação ao teste t para amostras relacionadas das médias de elasticidades-preço da demanda dos três tipos de marca, conforme os valores apresentados na tabela 31, rejeita-se, ao nível de erro de 1,67\%, a hipótese nula somente na comparação entre a marca de fabricante e a marca genérica para os optantes dessa última, sendo que as demais relações possuem valor de significância do teste maior do que o limiar de rejeição, definido como 1,67\%. Assim, para o único caso em que houve rejeição da hipótese nula, há indícios estatísticos de que as médias das elasticidades-preço da demanda das marcas são diferentes.

Tabela 31: Teste t das médias das elasticidades-preço da demanda segundo preferência declarada de tipo de marca da amostra

\begin{tabular}{|c|c|c|c|}
\hline Preferência & Marcas relacionadas & t & Sig. (bicaudal) \\
\hline \multirow{3}{*}{ Genérica } & Genérica/Social & 1,711 & 0,090 \\
\cline { 2 - 4 } & Genérica/Fabricante & 3,036 & 0,003 \\
\cline { 2 - 4 } & Social/Fabricante & 2,073 & 0,041 \\
\hline \multirow{3}{*}{ Fabricante } & Genérica/Social & 1,102 & 0,274 \\
\cline { 2 - 4 } & Genérica/Fabricante & 1,528 & 0,131 \\
\cline { 2 - 4 } & Social/Fabricante & 0,703 & 0,484 \\
\hline \multirow{3}{*}{ Social } & Genérica/Social & 1,381 & 0,171 \\
\cline { 2 - 4 } & Genérica/Fabricante & 2,090 & 0,040 \\
\cline { 2 - 4 } & Social/Fabricante & 0,647 & 0,519 \\
\hline
\end{tabular}

Desse modo, para o grupo que prefere a marca genérica, esse tipo de marca possui, estatisticamente, igual fidelidade por parte dos respondentes em relação à marca social e maior comparada à de fabricante. Já para os optantes da marca de fabricante, todos os três 
tipos de camiseta têm, estatisticamente, a mesma fidelidade por parte dos membros desse grupo; porém, a marca de fabricante apresenta a menor média das elasticidades entre os valores obtidos nos outros três grupos de optantes.

E, as pessoas que preferem a marca social também apresentam, estatisticamente, igual fidelidade entre os três tipos de marca, sendo a de fabricante a que possui a maior média de elasticidade. Vale notar que no grupo dos optantes pela marca social, as elasticidades das marcas possuem os maiores valores médios, ou seja, há indícios que esse é o grupo menos fiel às marcas. Além disso, exceto no caso da social, a marca declarada como preferida por um grupo apresenta nele a menor média de elasticidade entre os valores obtidos por ela nos demais grupos.

Em resumo, embora as marcas de fabricante para camisetas apresentem os maiores valores percebidos, seguidas pelas que possuem a marca social, elas não aparentam desfrutar da maior fidelidade dos respondentes, visto que a marca genérica, possui a menor elasticidade e, consequentemente, a maior fidelidade dos respondentes. Contudo, a marca social também pode desfrutar dessa mesma fidelidade em relação à genérica, sendo que isso vai depender da forma como ela é construída e do mercado a que se destina.

Como já mencionado, essa divergência entre a possibilidade de se aplicar preço diferenciado e o nível de fidelidade aos tipos de marca pode ter ocorrido devido ao modo como os dados foram coletados, pois, ao solicitar que o respondente determinasse quanto deveria ser o preço unitário de uma camiseta de cada tipo de marca a fim de se adquirirem duas semelhantes, ele exigiria uma redução de preço maior no caso das marcas mais caras, pois, devido ao alto valor, ele não teria interesse em comprar mais outra unidade parecida. Se fosse apresentada a possibilidade de comprar outra unidade que tivesse maior diferenciação, talvez os resultados fossem outros. 


\section{CONSIDERAÇÕES FINAIS}

Neste capítulo apresenta-se um entendimento que resume os resultados e conceitos apresentados neste trabalho, as limitações deste estudo e propostas para investigações futuras.

\subsection{Conclusão}

Com o crescimento populacional e o desenvolvimento econômico e tecnológico de alguns países, ocorreu um aumento da demanda por produtos, que foi incentivada pelo barateamento e proliferação deles nas gôndolas do varejo, decorrente da globalização, a qual derrubou as barreiras mercadológicas dos países e permitiu a obtenção de economias de escala em nível global. Categorias que não existiam foram criadas e as que já existiam foram ampliadas.

Contudo, o consumidor, pressionado por um mundo profissional e pessoal mais demandante, iniciou uma tendência declinante de tempo gasto nas compras dos supermercados. Isto impôs que as marcas se adaptassem a um novo contexto, no qual precisariam saltar aos olhos do consumidor, facilitando a sua experiência de compra e, desse modo, elas deixaram de ser meramente burocráticas e facilitadoras das transações para se tornarem poderosos signos de representação do ser, do comportamento, do posicionamento social e econômico, além de influenciadores da avaliação de valor dos seus produtos.

Com o refinamento do gosto dos consumidores em relação às marcas consumidas, passouse a exigir delas uma dimensão "espiritual”, relacionada aos seus valores sociais e éticos e ao envolvimento com a sociedade e o ambiente que impactam. Isso leva à criação de marcas diferenciadas por meio da parceria com entidades sem fins lucrativos, as quais, com o acirramento da competição por recursos, passaram a considerar as suas marcas como importantes para diferenciarem-se e angariarem o apoio necessário.

Durante esse movimento evolucionário, alguns tipos de marca foram criados e, atualmente, eles co-existem no mercado. Dada essa grande variedade, para viabilizar o estudo dos tipos de marca, realizou-se a categorização deles em três grandes conjuntos de marcas: marcas genéricas/commodities, marcas de fabricantes e marcas sociais. As marcas genéricas são basicamente as que concorrem por meio de preço, oferecendo a melhor qualidade possível a um determinado custo (normalmente baixo).

Já a marca de fabricante caracteriza-se por possuir um patrimônio construído sobre o seu know-how tecnológico e das necessidades do mercado; ser uma marca com tradição e reconhecimento entre os especialistas do produto ou serviço em questão e entre os 
consumidores; ter identidade e, consequentemente, alta diferenciação; e investir grandes quantias de dinheiro em comunicação. E, a marca social é uma vertente da marca de fabricante; assim, compartilha das mesmas características do grupo anterior, exceto pelo fato de que, ao invés de posicionar-se como altamente tecnológica e de prestígio, tem seu patrimônio baseado no conceito da responsabilidade social, da produção sustentável, com alto envolvimento com a natureza e a sociedade.

Visto que cada patrimônio de marca cria valor em uma variedade de formas, a fim de auxiliar na gestão efetiva de uma marca realizou-se, por meio deste trabalho, uma análise de alguns pontos relativos à influência da marca nas preferências do consumidor, comparando-se os efeitos dos três tipos estudados.

Foram consultadas, no Brasil, 260 pessoas para este trabalho; porém, a amostra válida consistiu de 248 respondentes e caracterizou-se por uma divisão quase igual entre os gêneros sexuais, uma concentração etária entre 18 e 35 anos, alto grau de instrução e renda familiar mensal, preferência declarada pelas camisetas mais baratas e pela qualidade e preço como os atributos citados como os mais importantes na decisão de compra desse produto.

A análise da preferência da amostra foi realizada com um grupo menor de respondentes, 184, e revelou que o tipo de camiseta preferido pela amostra é o de marca genérica, que não exibe nenhum signo aparente, com alta qualidade e baixo preço, sendo a qualidade, seguido pela marca e depois pelo preço, os atributos mais importantes para a preferência por uma camiseta.

Contudo, essa preferência da amostra altera-se quando se avaliam as opiniões de subgrupos de respondentes, formados segundo a predileção declarada deles por um dos tipos de marca estudados, sendo que a diferença consiste basicamente no modelo de camiseta escolhido, ocorrendo, nos três grupos, a confirmação da preferência, previamente declarada, pelo tipo de marca.

Os resultados obtidos por meio do modelo de preferência da amostra sugerem que a marca mantém considerável importância na decisão do consumidor; porém, este ainda preocupa-se em escolher camisetas cuja marca seja uma garantia de benefícios tangíveis, como a qualidade, e, se possível, não expresse de forma explícita os seus valores e ideais por meio de logos estampados, ou seja, ele não está preocupado com os significados de uma marca, o que o torna mais difícil de ser fidelizado.

Avaliando a estrutura de preferência dos 184 respondentes, foi possível perceber que há seis segmentos de consumidores com características bem definidas e distintas entre si, sendo que a preferência pelas marcas e a sensibilidade ao preço e qualidade variavam entre 
eles, gerando oportunidades que poderiam ser exploradas pelos três tipos de marca por intermédio de diferentes posicionamentos e estratégias.

Avaliou-se, também, a capacidade dos três tipos de marca em aplicar preço diferenciado para uma camiseta. Conforme a resposta dos 248 participantes, camisetas com marca de fabricante, em média, são as mais valiosas, seguidas pela social e genérica, sugerindo-se, desse modo, que o investimento no desenvolvimento do patrimônio de uma marca possibilita que a de fabricante e a social consigam aplicar, em média, preços diferenciados em relação à genérica (57\% e 25\% a mais, respectivamente), sendo que, por trabalhar com muitas propagandas e relacionar-se ao mercado da moda e, às vezes, de luxo, a de fabricante consegue desfrutar de um diferencial maior do que a social.

Esses resultados variam em magnitude quando se analisa a opinião dos respondentes segundo o gênero sexual ou a preferência declarada pelo tipo de marca, porém, o entendimento permanece o mesmo. É interessante notar que para as pessoas que declararam gostar da marca social, o preço diferenciado da marca de fabricante e social é estatisticamente o mesmo, ou seja, esse é o grupo que passa a valorizar as marcas que possuem uma dimensão “espiritual”.

E, estudando-se a elasticidade dos três tipos de marca diante da situação de se aumentar de uma para duas camisetas compradas, os 248 entrevistados demonstraram que a marca genérica possui, estatisticamente, menor elasticidade média quando comparada com a de fabricante, sendo que ambas são, estatisticamente, iguais ao valor obtido para a marca social. Esse resultado se repete, na maioria das vezes, quando se analisa a opinião dessas pessoas segundo o gênero sexual ou a preferência declarada pelo tipo de marca, embora, em alguns casos, os valores médios de elasticidade dos três tipos de marca sejam considerados estatisticamente iguais, ou seja, eles não conseguem diferenciar-se no grupo de consumidores pesquisados e, desse modo, não conseguem desfrutar de maior fidelidade deles em relação às demais marcas.

O que se sugere ao olhar a análise de elasticidade em parceria com a de diferencial de preço, ambas realizadas para os 248 participantes, é que por ser a camiseta de fabricante um produto de preço maior em relação às demais, a sensibilidade a mudanças dessa variável é, também, maior, pois esse tipo de camiseta passa a representar uma fatia maior do rendimento da pessoa, o que torna a compra de mais um produto de alto preço semelhante ao já adquirido menos interessante. Ademais, é válido observar que a marca social pode apresentar menor elasticidade do que a de fabricante, podendo isso ser decorrente do menor preço dela, mas também do seu posicionamento e do desenvolvimento de benefícios sócio-ambientais que as tornam diferenciadas e, desse modo, mais resistentes a alterações de preço devido a 
consumidores mais fiéis do que os da marca de fabricante, que possuem maior número de concorrentes com associações semelhantes.

Enfim, com os resultados aqui apresentados, acredita-se que foi possível apresentar uma análise comparativa exploratória sobre a influência das marcas sociais, genéricas e de fabricante sobre a opinião de valor e preferência de compra de uma camiseta, atingindo-se, desse modo, o objetivo proposto e acrescentando-se novos insumos para o campo de estudo de marcas e para a prática de gestão delas. A mensagem final que se obtém é que há indícios de que diferentes tipos de marcas são capazes de acrescentar valor a um produto em níveis variados, os quais dependem do segmento de consumidores que está sendo alvejado.

\subsection{Limitações do estudo}

Embora tenha sido conduzido com o alto rigor acadêmico possível, resultados aqui apresentados devem ser lidos com algumas ressalvas devido ao foco e à maneira como esse estudo foi desenvolvido. Primeiramente, as observações apresentadas limitam-se no tempo e espaço, pois, considerou-se a opinião de uma amostra da população brasileira maior de 18 anos, a qual foi coletada somente uma vez em março e julho de 2011. Assim, não é possível extrapolar esses dados para períodos muito distantes da coleta de dados, pois não se pode garantir que a opinião dos respondentes é consistente durante o tempo; e, também, para universos de pessoas diferentes do pesquisado.

Por não ter sido extraída uma amostra representativa da população de interesse e nem selecionado aleatoriamente os participantes, os resultados obtidos não podem ser generalizados para todo o universo de pesquisa e, desse modo, guardam um caráter de informações exploratórias. Ademais, a amostra apresentou uma concentração muito grande em termos de nível educacional e de renda familiar mensal, o que acabou por reduzir ainda mais a sua representatividade.

Tendo sido elaborada especificamente para a realização da análise conjunta, a questão cinco do instrumento de coleta de dados era complexa e pode ter gerado uma sobrecarga de informação para alguns respondentes, o que é comum para essa técnica, segundo Lambin (2000), e, desse modo, para simplificar a tarefa, os inquiridos que sentiram essa dificuldade podem ter ignorado as variações de características dos produtos consideradas menos importantes e ter realizado uma ordenação das opções de modo não representativo da sua realidade.

Também, para o alcance do objetivo proposto, na análise conjunta das opiniões sobre as camisetas, utilizaram-se como variáveis de estudo apenas a marca e dois aspectos que ela 
pode influenciar, os quais são a qualidade e o preço. Outras características que podem ser importantes na avaliação de camisetas não foram consideradas e, caso fossem, talvez pudessem conduzir a resultados diferentes dos apresentados. Assim, é importante ter em mente que outros atributos do produto podem influenciar a preferência por ele e os resultados aqui apresentados são válidos somente quando os fatores do bem avaliado, além da marca, qualidade e preço, são mantidos constantes.

Sobre os resultados do teste de elasticidade, ressalta-se que ele é limitado à situação em que a quantidade consumida passa de uma unidade para duas. Ademais, nessa análise, houve uma alta variância em relação à média; porém, a fim de conservar a amostra estudada, ela foi aceita e considerada como decorrente da variedade de opinião entre as pessoas do universo de interesse.

Portanto, com as limitações e resultados apresentados, faz-se a seguir sugestões de estudos futuros para testar os achados deste estudo exploratório e reduzir os limites impostos pelos métodos e amostra utilizados neste trabalho.

\subsection{Recomendações de estudos futuros}

Entre as recomendações de estudos futuros para testar os resultados deste estudo, têmse a sua replicação com uma amostra maior, representativa, escolhida de forma aleatória e com melhor distribuição de algumas características sócio-demográficas, como nível de escolaridade e renda familiar mensal. Ademais, sugere-se colher a opinião dos respondentes em dois momentos distintos, a fim de avaliar a sua consistência no tempo.

Um estudo cuja coleta de dados seja feita pessoalmente e com produtos físicos que possam ser avaliados pode facilitar para o respondente a tarefa complexa de se analisar de forma conjunta todos os atributos dos objetos estudados, tornando a situação de estudo mais próxima da real ao reduzir-se a probabilidade de ocorrer uma simplificação intencional da tarefa (por meio da decisão de predileção com base em somente um atributo, por exemplo), a qual pode ocorrer no caso de uma avaliação complexa com o apoio apenas de uma descrição dos produtos.

Outra proposta interessante é avaliar se as mesmas respostas obtidas para camisetas se replicam para outros bens de consumo não-duráveis e, também, para os duráveis, a fim de avaliar se os resultados podem ser generalizados para outros mercados. Além disso, esse estudo poderia ser replicado em outros países para avaliar se as mesmas opiniões se manifestam internacionalmente e comparar os valores obtidos.

Já a análise de elasticidade poderia ser testada para outros pontos de demanda, a fim de se avaliarem as possíveis alterações desse indicador nos demais níveis de consumo. E, na 
coleta de dados para essa análise, ao invés de solicitar o valor unitário dos produtos na situação em que a quantidade comprada precisa ser maior do que uma unidade, recomenda-se perguntar o desconto necessário no valor unitário para que a compra seja realizada, pois, dessa forma, diminui-se a chance de inconsistência dos dados com a situação em que a compra de somente uma unidade é possível e motiva-se o respondente a exercer uma diferenciação dos preços na nova situação, reduzindo-se, assim, a ocorrência de casos de inelasticidade absoluta e possibilitando a verificação da semelhança entre a elasticidade da marca social e das outras duas ser decorrente da real opinião dos entrevistados ou do modo como os dados foram coletados neste estudo.

Por fim, com esses trabalhos futuros sugeridos, acredita-se que é possível testar a validade externa dos resultados apresentados neste estudo e resolver algumas limitações que foram elencadas na seção anterior. 


\section{REFERÊNCIAS}

AAKER, D. A. Building strong brands. New York: The Free Press, 1996.

AAKER, D. A.; JOACHIMSTHALER, E. Como construir marcas líderes. Porto Alegre: Bookman, 2007.

AAKER, D. A.; KUMAR, V.; DAY, G. S. Marketing research. 5. ed. New York: John Wiley \& Sons, Inc., 1995.

ALCAÑIZ, E. B.; CÁCERES, R. C.; PÉREZ, R. C. Alliances between brands and social causes: the influence of company credibility on social responsibility image. Journal of Business Ethics: Dordrecht: v. 96, n. 2, p. 169 -186. 2010

AMERICAN MARKETING ASSOCIATION - AMA. Dictionary. Disponível em: << http://www.marketingpower.com/_layouts/Dictionary.aspx?dLetter=B >>. Acesso em: 02 dez. 2009.

ANDERSON, D. R.; SWEENEY, D. J.; WILLIAMS, T. A. Estatística aplicada à administração e economia. 2ed. São Paulo: Cengage Learning, 2008.

BLOMQVIST, K. H.; POSNER, S. Three strategies for integrating CSR with brand marketing. Market Leader. Verão 2004. Disponível em << www.warc.com/marketleader $>>$. Acesso em 01 mai. 2008

BORGES, D. L. Bancos possuem marcas mais valiosas do país, diz consultoria. Infomoney. 2011. Disponível em << www.infomoney.com.br >>. Acesso em 09 jun. 2011.

BRANDZ. Brand dynamic pyramid. 2009. Disponível em: < http://www.brandz.com/output/Branddynamicpyramid.aspx >>. Acesso em 03 dez. 2009.

BRONN, P. S.; VRIONI, A. B. Corporate social responsibility and cause-related marketing: an overview. International Journal of Advertising: [S.l.]: v. 20, p. 207-222. 2001. 
CAlAntOnE, R. J.; DI BEnEDETTO, A. A.; HAKAM, A.; BOJANIC, D. C. Multiple multinational tourism positioning using correspondence analysis. Journal of Travel Research: Boulder, v. 28, n. 2, p. 25-32. Fall, 1989.

CALDWELL, N; COSHALL, J. Measuring brand associations for museums and galleries using repertory grid analysis. Management Decision: London, v. 40, n. 4, p. 383-392. 2002.

COOPER, D. R.; SCHINDLER, P. S. Métodos de pesquisa em administração. 7 ed. Porto Alegre: Bookman, 2003.

CRAVENS, D. W. Strategic marketing. 4 ed. Burr Ridge: Irwin, 1994.

CRAVENS, D. W; PIERCY, N. F. Marketing estratégico. 8 ed. São Paulo: McGraw-Hill, 2007.

DARNALL, N. Creating a green brand for competitive distinction. Asian Business e Management: Houndmills, v. 7, n. 4, p. 445-466. 2008.

D’EMIDIO, M. O valor de marca: uma abordagem de equações estruturais. 2009. 115p. Tese (Doutorado em Administração) - Faculdade de Economia, Administração e Contabilidade, Universidade de São Paulo, São Paulo.

ELLWOOD, I. O livro essencial das marcas: tudo o que você precisa saber, em mais de 100 técnicas para aumentar o valor das marcas. São Paulo: Clio Editora, 2004.

EWING, M. T; NAPOLI, J. Developing and validating a multidimensional nonprofit brand orientation scale. Journal of Business Research: New York, v. 58, n. 6, p. 841-853. 2005.

FAIRCLOTH, J. B. Factor influencing nonprofit resource provider support decisions: applying the brand equity concept to nonprofits. Journal of Marketing Theory and Practice: Armonk, v. 13, n. 3, p. 1-15. 2005.

FURRIER, M. T. Patrimônio de marca. In: SERRALVO, F. A. [org]; YAMAGUTI, C. L.; et. al. Gestão de marcas no contexto brasileiro. São Paulo: Saraiva, 2008. p. 133-162. 
Posicionamento e reposicionamento de marcas. In: SERRALVO, F. A. [org]; YAMAGUTI, C. L.; et. al. Gestão de marcas no contexto brasileiro. São Paulo: Saraiva, 2008b. p. 163-209.

GILLIGAN, C; GOLDEN, L. Re-branding social good: social profit as a new conceptual framework. Academy of Marketing Studies Journal: Cullowhee, v. 13, n. 2, p. 97-117. 2009

HAIR JR., J. F.; BLACK, W. C.; BABIN, B. J.; ANDERSON, R. E.; TATHAM, R. L.; Multivariate data analysis. 6 ed. Upper Saddle River: Prentice Hall, 2006.

HERING. Hering webstore. 2011. Disponível em: << http://www.heringwebstore.com.br/loja/ >>. Acesso em: 09 jul. 2011.

HOEFFLER, S.; KELLER, K. L. Building brand equity through corporate societal marketing. Journal of Public Policy \& Marketing: Chicago: v. 21, n. 1; p. 78-89. 2002.

PRODUTOS verdes: nos EUA, 50\% pagariam a mais por eles; no Brasil, 37\%. Infomoney. 2008. Disponível em <<www.infomoney.com.br >>. Acesso em 01 ago. 2008.

INSTITUTO BRASILEIRO DE GEOGRAFIA E ESTATÍSTICA - IBGE. Censo demográfico 2010. 2011. Disponível em: < http://www.ibge.gov.br/home/estatistica/populacao/censo2010/default_sinopse.shtm >>. Acesso em: 09 jul. 2011.

IPSOS-ASI. Equity*Builder. 2010. Disponível em $<<$ http://www.ipsos.com.br $>>$. Acesso em: 03 out. 2011.

JOHNSON, R. A.; WICHERN, D. W. Applied multivariate statistical analysis. 3 ed. Englewood Cliffs: Prentice Hall, 1992

KAPFERER, J. N. Marcas à prova de prática: aprendendo com os erros. 2 ed. Porto Alegre: Bookman, 2004a 
O que vai mudar as marcas. Porto Alegre: Bookman, 2004b

As marcas, capital da empresa: criar e desenvolver marcas fortes. 3 ed.

Porto Alegre: Bookman, 2003.

KELLER, K. L. Strategic Brand Management. Upper Saddle River: Prentice Hall, 2002.

KHAN, H; EDE, D. How do not-for-profit SMEs attempt to develop a strong brand in an increasingly saturated market? Journal of Small Business and Enterprise Development: Bradford, v. 16, n. 2, p. 335-354. 2009.

KHAUAJA, D. M. R. Construção de marcas. In: SERRALVO, F. A. [org]; YAMAGUTI, C. L.; et. al. Gestão de marcas no contexto brasileiro. São Paulo: Saraiva, 2008. p. 77-131

. Fatores de marketing na construção de marcas sólidas: estudo exploratório com marcas brasileiras. 2005. 239p. Dissertação (Mestrado em Administração) - Faculdade de Economia, Administração e Contabilidade, Universidade de São Paulo, São Paulo

KHAUAJA, D. M. R.; PRADO, K. P. L. A. Contextualização das marcas. In: SERRALVO, F. A. [org]; YAMAGUTI, C. L.; et. al. Gestão de marcas no contexto brasileiro. São Paulo: Saraiva, 2008. p. 11-35

KOTLER, P. Administração de marketing. São Paulo: Prentice Hall. 2000.

KOTLER, P.; KELLER, K. L. Administração de marketing. 12 ed. São Paulo: Pearson Prentice Hall, 2006.

KUMAR, N.; STEENKAMP, J. B. E. M. Estratégia de marca própria. São Paulo: M. Books, 2008. 
LAFFERTY, B. A.; GOLDSMITH, R.E. Cause-brand alliances: does the cause help the brand or does the brand help the cause? Journal of Business Research: New York: v. 58, n. 4, p. 423-429. 2005.

LAFFERTY, B. A.; GOLDSMITH, R.E.; HULT, G. T. M. The impact of the alliance on the partners: a look at cause-brand alliances. Psychology \& Marketing: Hoboken, v. 21, n. 7, p. 509-531. July, 2004.

LAMBIN, J. J. Marketing estratégico. Lisboa: McGraw-Hill, 2000.

LEITCH, S. R; DAVENPORT, S. Corporate brands and social brands: co-branding GM-free and UK supermarkets. International Studies of Management and Organizations: White Plains, v. 37, n. 4, p. 45-63. Winter, 2007.

MAGALHÃES, G. F. Mais de $60 \%$ das pessoas preferem marcas que ajudam a ajudar os outros. Infomoney. 2011. Disponível em $<<$ www.infomoney.com.br $>>$. Acesso em 15 jun. 2011.

MAIO, E. Managing brand in the new stakeholder environment. Journal of Business Ethics: Dordrecht, v. 44, n. 2/3, p. 235-246. May, 2003

MANKIW, N. G. Introdução à economia: princípios de micro e macroeconomia. 2 ed. Rio de Janeiro: Campus, 2001.

MIRANDA, A. P. C. Comportamento de consumo simbólico: a marca como instrumento da relação pessoa-objeto. 2006. 210p. Tese (Doutorado em Administração) - Faculdade de Economia, Administração e Contabilidade, Universidade de São Paulo, São Paulo.

MOHR, L.A.; WEBB, D. J. The effects of corporate social responsibility and price on consumer responses. The Journal of Consumer Affairs: Madison, v. 39, n. 1, p. 121-147. Summer, 2005. 
MORT, G. S.; WEERAWARDENA, J.; WILLIAMSON, B. Branding in the non-profit context: the case of Surf Life Saving Australia. Australasian Marketing Journal: St. Lucia, v. 15, n. 2, p. 108-119. 2007.

MOWEN, J. C.; MINOR, M. S. Comportamento do consumidor. 1ed. São Paulo: Prentice Hall, 2003.

NUNES, F. F. Brasileiro preza mais marca de preço baixo na compra de bebidas. Infomoney. 2008. Disponível em << www.infomoney.com.br >>. Acesso em 22 out. 2008.

PEREZ, C. Signos da marca: expressividade e sensorialidade. São Paulo: Pioneira Thomson, 2004.

PINDYCK, R. S; RUBINFELD, D. L. Microeconomia. 5ed. São Paulo: Prentice Hall, 2002.

POLONSKY, M. J; JEVONS, C. Understanding issue complexity when building a socially responsible brand. European Business Review: Bradford, v. 18, n. 5, p. 340-349. 2006.

PRACEJUS, J. W; OLSEN, G. D; BROWN, N. R. On the prevalence and impact of vague quantifiers in the advertising of cause-related marketing (CRM). Journal of Advertising: Armonk, v. 32, n. 6, p. 19-28. Winter 2003/2004.

PRADO, K. P. L. A; FARINHA, H. Classificação e estratégias de marcas. In: SERRALVO, F. A. [org]; YAMAGUTI, C. L.; et. al. Gestão de marcas no contexto brasileiro. São Paulo: Saraiva, 2008. p. 37-75.

SERRALVO, F. A; FURRIER, M. T. Tipologías del posicionamento de marcas, un estudio conceptual en Brasil y en España. Revista Galega de Economia: Santiado de Compostela, v 14, n 1-2, p 1-15. 2005

SIEGEL, S; CASTELLAN JR., N. J. Estatística não-paramétrica para ciências do comportamento. 2ed. Porto Alegre: Artmed, 2006. 
STEENKAMP, J. B. E. M; BATRA, R; ALDEN, D. L. How perceived brand globalness creates brand value. Journal of International Business Studies: Washington, v. 34, n. 1, p. 53-65. 2003.

SUBRAHMANYAN, S. Effects of price premium and product type on the choice of causerelated brands: a Singapore perspective. Journal of Product and Brand Management: Santa Barbara, v. 13, n. 2; p. 116-124. 2004

VALLONE. G. Classe C se consolida como a maior do Brasil em 2008. Estadão.com.br. 2009. Disponível em: << http://www.estadao.com.br/economia/not_eco396290,0.htm >>. Acesso em: 01 dez. 2009.

VENABLE, T. B; ROSE, G. M; BUSH, V. D; GILBERT, F. W. The role of brand personality in charitable giving: an assessment and validation. Journal of the Academy of Marketing Science: Greenvale, v. 33, n. 3, p. 295-312. 2005.

WYMER, W; SAMU, S. The influence of cause marketing associations on product and cause brand value. International Journal of Nonprofit and Voluntary Sector Marketing: London, v. 14, n. 1, p. 1-19. 2009. 


\section{APÊNDICES}

APÊNDICE 1: EXEMPLO DE E-MAIL CONVITE PARA PARTICIPAÇÃO NA PESQUISA

APÊNDICE 2: QUESTIONÁRIO UTILIZADO NA COLETA DE DADOS

APÊNDICE 3: ESQUEMA DE AGLOMERAÇÃO DO MÉTODO HIERÁRQUICO 


\section{Apêndice 1: Exemplo de e-mail convite para participação na pesquisa}

Assunto: Auxílio para divulgação de questionário de dissertação da FEA/USP

Bom dia!

Meu nome é Luiz Alberto Marcondes Homen de Mello e Castro, sou aluno de Mestrado do Programa de Pós-Graduação em Administração da Faculdade de Economia, Administração e Contabilidade da Universidade de São Paulo (FEA/USP) e estou elaborando, sob a orientação da Profa. Dra. Maria Aparecida Gouvêa, a dissertação "AVALIAÇÃO DA INFLUÊNCIA DAS MARCAS SOCIAIS, DE FABRICANTE E GENÉRICAS NA DECISÃO DE COMPRA", a qual possui o intuito de detectar a influência de diferentes tipos de marcas sobre a decisão de compra de camisetas.

Por favor, você poderia auxiliar-me repassando a mensagem abaixo para os alunos do Programa de Pós-Graduação em Administração da Universidade Federal de Santa Maria UFSM?

Olá!

Meu nome é Luiz Alberto Marcondes Homen de Mello e Castro, sou aluno de Mestrado do Programa de Pós-Graduação em Administração da Faculdade de Economia, Administração e Contabilidade da Universidade de São Paulo (FEA/USP) e estou elaborando, sob a orientação da profa. dra. Maria Aparecida Gouvêa, a dissertação "AVALIAÇÃO DA INFLUÊNCIA DAS MARCAS SOCIAIS, DE FABRICANTE E GENÉRICAS NA DECISÃO DE COMPRA", a qual possui o intuito de detectar a influência de diferentes tipos de marcas sobre a decisão de compra de camisetas.

Solicito a vossa ajuda por meio do preenchimento do meu questionário da minha dissertação (composto por apenas 9 questões sobre a decisão de compra de camisetas) que está disponível no link abaixo.

http:/questionpro.com/t/CJWmAZEzmEo

Grato pela vossa colaboração.

Luiz Alberto M. H. de M. e Castro. 


\section{Apêndice 2: Questionário utilizado na coleta de dados}

1) O seu gênero sexual é:

( ) Masculino

( ) Feminino

2) A sua idade é: anos

3) O seu grau de instrução é:

( ) Primeiro Grau Incompleto

( ) Superior Incompleto

( ) Primeiro Grau Completo

( ) Superior Completo

( ) Segundo Grau Incompleto

( Pós-Graduação (MBA, Mestrado ou Doutorado)

( ) Segundo Grau Completo

4) A sua renda familiar é:

( ) Menos de R $\$ 1000$

（ ） De R\$ 5.000 a R \$ 6.999

（ ） De R\$ 1000 a R\$ 1.999

（ ） De R\$ 7.000 a R\$ 8.999

（） ） De R 2.000 a R\$ 2.999

( ) $\mathrm{R} \$ 9.000$ ou mais

（） ） De R 3.000 a R\$ 4.999 
5) Abaixo há 12 diferentes camisetas brancas de manga curta. Ordene, de $\underline{\mathbf{1}}$ a $\underline{\mathbf{1 2}}$, por ordem de preferência em relação aos atributos revelados, as camisetas da tabela abaixo, sendo que $\underline{\mathbf{1}}$ é a camiseta mais preferida e $\mathbf{1 2}$ é a camiseta menos preferida. Não pode haver empates de preferência.

\section{Legenda:}

Modelo X: Sem estampas

$\underline{\text { Modelo Y: }}$ : Possui o símbolo de uma famosa causa social estampado na frente

Modelo Z: Possui o símbolo de uma marca de roupas, que faz muitos comerciais na TV, estampado na frente

\begin{tabular}{|c|c|c|c|c|}
\hline & Modelo & Preço & Qualidade & Preferência \\
\hline \multirow{12}{*}{ 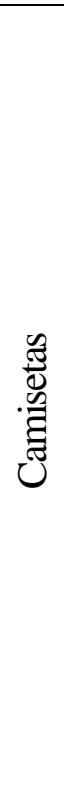 } & $\mathrm{Z}$ & Baixo & Alta & \\
\hline & $\mathrm{Z}$ & Alto & Média & \\
\hline & $\mathrm{X}$ & Alto & Alta & \\
\hline & $\mathrm{Z}$ & Alto & Alta & \\
\hline & $\bar{Y}$ & Médio & Média & \\
\hline & $\mathrm{X}$ & Baixo & Baixa & \\
\hline & $\bar{Y}$ & Médio & Alta & \\
\hline & $\mathrm{Y}$ & Alto & Baixa & \\
\hline & $\mathrm{X}$ & Médio & Média & \\
\hline & $\mathrm{X}$ & Alto & Baixa & \\
\hline & $\mathrm{Y}$ & Baixo & Média & \\
\hline & Z & Médio & Baixa & \\
\hline
\end{tabular}


6) Para você aceitar comprar, quanto deveria custar uma camiseta branca de manga curta, qualidade média, dos modelos abaixo?

\section{Legenda:}

Modelo X: Sem estampas

Modelo Y: Possui o símbolo de uma famosa causa social estampado na frente

Modelo Z: Possui o símbolo de uma marca de roupas, que faz muitos comerciais na TV, estampado na frente

\section{Preço (R\$)}

\begin{tabular}{|l|l|}
\hline Modelo $\mathbf{X}$ \\
\hline Modelo $\mathbf{Y}$ \\
\hline Modelo Z \\
\hline
\end{tabular}

7) Para você aceitar comprar, no mesmo momento, duas camisetas de manga curta, qualidade média, do mesmo modelo, mas com cores diferentes, quanto deveria custar cada uma delas?

\section{Legenda:}

$\underline{\text { Modelo X: }}$ : Sem estampas

$\underline{\text { Modelo Y }}$ : Possui o símbolo de uma famosa causa social estampado na frente

Modelo Z: Possui o símbolo de uma marca de roupas, que faz muitos comerciais na TV, estampado na frente

\section{Preço de cada camiseta (R\$)}

\begin{tabular}{|l|}
\hline 2 Camisetas do Modelo $X$ \\
\hline 2 Camisetas do Modelo $Y$ \\
\hline 2 Camisetas do Modelo $Z$ \\
\hline
\end{tabular}

8) Ao escolher uma camiseta, você prefere:

( ) A mais barata

( ) A que está sendo anunciada em comerciais na TV

( ) A produzida por uma empresa envolvida com causas sociais e/ou ambientais 
9) Ordene de 1 a 4 os atributos abaixo segundo a importância deles para você na decisão de compra de uma camiseta, sendo $1 \mathrm{o}$ atributo mais importante e 4 o menos importante. Não pode haver empates de preferência.

( ) Preço

( ) Marca

( ) Qualidade

( ) Envolvimento com uma causa social ou ambiental 
Apêndice 3: Esquema de aglomeração do método hierárquico

\begin{tabular}{|c|c|c|c|}
\hline \multirow{2}{*}{ Estágio } & \multicolumn{2}{|c|}{ Aglomeração } & \multirow{2}{*}{$\begin{array}{l}\text { Coeficiente de } \\
\text { variância }\end{array}$} \\
\hline & Grupo1 & Grupo2 & \\
\hline 1 & 156 & 179 & ,000 \\
\hline 2 & 29 & 176 & ,000 \\
\hline 3 & 20 & 153 &, 000 \\
\hline 4 & 148 & 151 &, 000 \\
\hline 5 & 68 & 148 & ,000 \\
\hline 6 & 54 & 147 &, 000 \\
\hline 7 & 118 & 136 &, 000 \\
\hline 8 & 106 & 131 & ,000 \\
\hline 9 & 111 & 118 &, 000 \\
\hline 10 & 64 & 105 & ,000 \\
\hline 11 & 63 & 98 & ,000 \\
\hline 12 & 3 & 96 &, 000 \\
\hline 13 & 1 & 20 &, 000 \\
\hline 14 & 52 & 121 & 4,930E-32 \\
\hline 15 & 108 & 177 & 1,602E-31 \\
\hline 16 & 40 & 157 & 1,661E-31 \\
\hline 17 & 40 & 57 & 2,802E-31 \\
\hline 18 & 29 & 62 & 3,361E-31 \\
\hline 19 & 31 & 108 & 5,023E-31 \\
\hline 20 & 49 & 101 & 1,347E-30 \\
\hline 21 & 60 & 183 & 9,400E-02 \\
\hline 22 & 145 & 171 & 9,400E-02 \\
\hline 23 & 52 & 166 & 9,400E-02 \\
\hline 24 & 91 & 146 & 9,400E-02 \\
\hline 25 & 26 & 132 & 9,400E-02 \\
\hline 26 & 115 & 124 & $9,400 \mathrm{E}-02$ \\
\hline 27 & 1 & 86 & 9,400E-02 \\
\hline 28 & 29 & 84 & 9,400E-02 \\
\hline 29 & 22 & 56 & $9,400 \mathrm{E}-02$ \\
\hline 30 & 13 & 47 & 9,400E-02 \\
\hline 31 & 31 & 40 & 9,400E-02 \\
\hline 32 & 3 & 156 & ,154 \\
\hline 33 & 100 & 152 & ,154 \\
\hline 34 & 51 & 143 & ,154 \\
\hline 35 & 5 & 140 & ,154 \\
\hline 36 & 46 & 139 & ,154 \\
\hline 37 & 122 & 129 & ,154 \\
\hline 38 & 21 & 117 & ,154 \\
\hline 39 & 8 & 90 & ,154 \\
\hline 40 & 14 & 85 & ,154 \\
\hline 41 & 36 & 74 & ,154 \\
\hline 42 & 11 & 70 & ,154 \\
\hline 43 & 6 & 49 & ,154 \\
\hline 44 & 1 & 10 & , 160 \\
\hline 45 & 73 & 137 & ,162 \\
\hline 46 & 94 & 133 & ,162 \\
\hline 47 & 42 & 125 & ,162 \\
\hline 48 & 50 & 116 & ,164 \\
\hline 49 & 35 & 75 & ,164 \\
\hline 50 & 17 & 64 &, 164 \\
\hline 51 & 33 & 115 & ,168 \\
\hline 52 & 81 & 168 & ,168 \\
\hline 53 & 76 & 154 & ,168 \\
\hline
\end{tabular}




\begin{tabular}{|c|c|c|c|}
\hline \multirow{2}{*}{ Estágio } & \multicolumn{2}{|c|}{ Aglomeração } & \multirow{2}{*}{$\begin{array}{c}\text { Coeficiente de } \\
\text { variância }\end{array}$} \\
\hline & Grupo1 & Grupo2 & \\
\hline 54 & 15 & 69 &, 168 \\
\hline 55 & 128 & 159 & ,172 \\
\hline 56 & 37 & 106 & ,172 \\
\hline 57 & 48 & 54 & ,172 \\
\hline 58 & 34 & 41 & ,172 \\
\hline 59 & 169 & 181 & ,176 \\
\hline 60 & 71 & 174 & ,176 \\
\hline 61 & 65 & 87 & ,176 \\
\hline 62 & 26 & 29 & ,198 \\
\hline 63 & 161 & 178 & ,205 \\
\hline 64 & 95 & 149 & ,205 \\
\hline 65 & 18 & 43 & ,215 \\
\hline 66 & 58 & 88 & ,219 \\
\hline 67 & 111 & 182 & ,223 \\
\hline 68 & 2 & 38 & ,223 \\
\hline 69 & 48 & 93 & ,223 \\
\hline 70 & 109 & 122 & ,230 \\
\hline 71 & 5 & 68 & ,230 \\
\hline 72 & 26 & 30 & ,239 \\
\hline 73 & 79 & 128 & ,246 \\
\hline 74 & 28 & 102 & ,247 \\
\hline 75 & 6 & 18 & ,258 \\
\hline 76 & 9 & 46 & ,260 \\
\hline 77 & 21 & 24 & ,260 \\
\hline 78 & 37 & 104 & ,269 \\
\hline 79 & 31 & 111 & ,270 \\
\hline 80 & 32 & 50 & ,275 \\
\hline 81 & 33 & 89 & 279 \\
\hline 82 & 119 & 162 & ,315 \\
\hline 83 & 52 & 100 & ,322 \\
\hline 84 & 44 & 83 & ,326 \\
\hline 85 & 17 & 145 & ,333 \\
\hline 86 & 25 & 77 & ,333 \\
\hline 87 & 59 & 113 & ,344 \\
\hline 88 & 48 & 66 & ,367 \\
\hline 89 & 1 & 6 & ,374 \\
\hline 90 & 19 & 71 & ,402 \\
\hline 91 & 9 & 55 & ,412 \\
\hline 92 & 28 & 109 & ,450 \\
\hline 93 & 39 & 95 & ,480 \\
\hline 94 & 21 & 97 & ,481 \\
\hline 95 & 45 & 150 & ,486 \\
\hline 96 & 5 & 32 & ,492 \\
\hline 97 & 103 & 107 & ,494 \\
\hline 98 & 8 & 81 & ,544 \\
\hline 99 & 80 & 126 & ,548 \\
\hline 100 & 76 & 161 & ,550 \\
\hline 101 & 12 & 51 & ,550 \\
\hline 102 & 2 & 17 & ,552 \\
\hline 103 & 67 & 99 & ,561 \\
\hline 104 & 21 & 160 & ,570 \\
\hline 105 & 22 & 135 & ,576 \\
\hline 106 & 14 & 26 & ,581 \\
\hline 107 & 13 & 141 & ,586 \\
\hline 108 & 91 & 120 & ,592 \\
\hline 109 & 19 & 112 & ,601 \\
\hline
\end{tabular}




\begin{tabular}{|c|c|c|c|}
\hline \multirow{2}{*}{ Estágio } & \multicolumn{2}{|c|}{ Aglomeração } & \multirow{2}{*}{$\begin{array}{c}\text { Coeficiente de } \\
\text { variância }\end{array}$} \\
\hline & Grupo1 & Grupo2 & \\
\hline 110 & 25 & 163 & ,605 \\
\hline 111 & 60 & 180 & ,611 \\
\hline 112 & 3 & 11 & ,612 \\
\hline 113 & 36 & 119 & ,674 \\
\hline 114 & 1 & 158 & ,683 \\
\hline 115 & 61 & 123 & ,701 \\
\hline 116 & 16 & 144 & ,706 \\
\hline 117 & 5 & 34 & ,723 \\
\hline 118 & 82 & 130 & ,737 \\
\hline 119 & 15 & 78 & ,741 \\
\hline 120 & 9 & 164 & ,747 \\
\hline 121 & 155 & 175 & ,748 \\
\hline 122 & 9 & 33 & ,832 \\
\hline 123 & 21 & 22 & ,841 \\
\hline 124 & 63 & 172 & ,848 \\
\hline 125 & 59 & 79 & ,848 \\
\hline 126 & 35 & 110 & ,879 \\
\hline 127 & 72 & 184 & ,885 \\
\hline 128 & 94 & 138 & ,917 \\
\hline 129 & 31 & 65 & ,929 \\
\hline 130 & 5 & 37 & ,962 \\
\hline 131 & 7 & 67 & 1,059 \\
\hline 132 & 21 & 53 & 1,070 \\
\hline 133 & 58 & 92 & 1,081 \\
\hline 134 & 94 & 103 & 1,087 \\
\hline 135 & 1 & 31 & 1,102 \\
\hline 136 & 8 & 14 & 1,109 \\
\hline 137 & 13 & 45 & 1,134 \\
\hline 138 & 169 & 173 & 1,134 \\
\hline 139 & 27 & 91 & 1,193 \\
\hline 140 & 73 & 114 & 1,214 \\
\hline 141 & 80 & 167 & 1,228 \\
\hline 142 & 39 & 59 & 1,305 \\
\hline 143 & 7 & 15 & 1,368 \\
\hline 144 & 2 & 63 & 1,370 \\
\hline 145 & 13 & 82 & 1,376 \\
\hline 146 & 5 & 36 & 1,380 \\
\hline 147 & 4 & 165 & 1,383 \\
\hline 148 & 28 & 170 & 1,409 \\
\hline 149 & 25 & 42 & 1,473 \\
\hline 150 & 16 & 23 & 1,526 \\
\hline 151 & 27 & 44 & 1,604 \\
\hline 152 & 19 & 80 & 1,783 \\
\hline 153 & 21 & 155 & 1,833 \\
\hline 154 & 8 & 48 & 1,943 \\
\hline 155 & 12 & 169 & 1,965 \\
\hline 156 & 7 & 16 & 2,034 \\
\hline 157 & 35 & 127 & 2,135 \\
\hline 158 & 1 & 5 & 2,148 \\
\hline 159 & 9 & 13 & 2,176 \\
\hline 160 & 52 & 142 & 2,259 \\
\hline 161 & 25 & 58 & 2,405 \\
\hline 162 & 8 & 27 & 2,669 \\
\hline 163 & 52 & 73 & 2,677 \\
\hline 164 & 9 & 39 & 2,796 \\
\hline 165 & 35 & 76 & 3,025 \\
\hline
\end{tabular}




\begin{tabular}{|c|c|c|c|}
\hline \multirow{2}{*}{ Estágio } & \multicolumn{2}{|c|}{ Aglomeração } & \multirow{2}{*}{$\begin{array}{c}\text { Coeficiente de } \\
\text { variância }\end{array}$} \\
\cline { 2 - 3 } & Grupo1 & Grupo2 & 3,246 \\
\hline 166 & 21 & 28 & 3,507 \\
\hline 167 & 3 & 72 & 3,690 \\
\hline 168 & 12 & 19 & 3,923 \\
\hline 169 & 1 & 8 & 4,508 \\
\hline 170 & 4 & 134 & 4,563 \\
\hline 171 & 2 & 7 & 4,744 \\
\hline 172 & 9 & 35 & 4,767 \\
\hline 173 & 52 & 94 & 5,097 \\
\hline 174 & 1 & 25 & 5,689 \\
\hline 175 & 4 & 12 & 6,154 \\
\hline 176 & 1 & 21 & 6,417 \\
\hline 177 & 52 & 61 & 6,772 \\
\hline 178 & 1 & 9 & 10,142 \\
\hline 179 & 1 & 4 & 12,062 \\
\hline 180 & 1 & 3 & 13,806 \\
\hline 181 & 2 & 60 & 14,773 \\
\hline 182 & 1 & 2 & 17,974 \\
\hline 183 & 1 & 52 & \\
\hline
\end{tabular}

